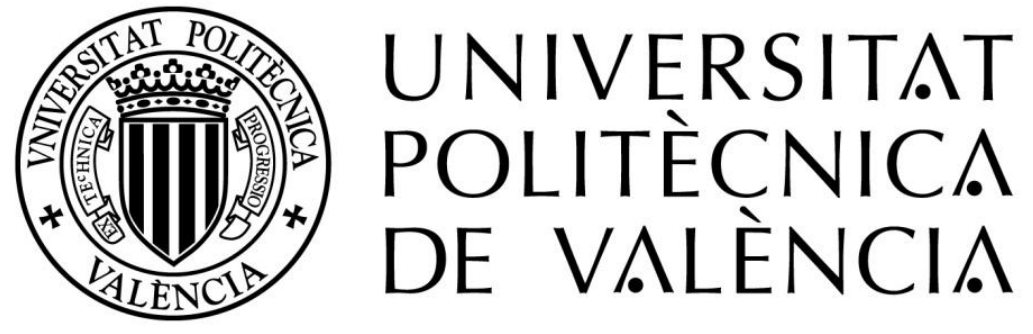

\title{
SISTEMA DE CULTIVO PARA MEJORAR LA VIABILIDAD DE EMBRIONES BOVINOS PRODUCIDOS IN VITRO
}

Tesis de doctorado (PhD)

Antonio Vinicio Murillo Ríos

Directores de Tesis:

Dr. Marta Muñoz Llamosas

Dr. Enrique Gómez Piñeiro

Valencia, Junio 2018 



\title{
UNIVERSITAT POLITÈCNICA DE VALÈNCIA
}

\section{SISTEMA DE CULTIVO PARA MEJORAR LA VIABILIDAD DE EMBRIONES BOVINOS PRODUCIDOS IN VITRO}

\author{
Tesis presentada a la Universidad Politécnica de Valencia en \\ cumplimiento parcial de los requisitos para el grado de \\ Doctor en Filosofía (PhD)
}

Presentada por

Antonio Vinicio Murillo Ríos

Firma

Directores de Tesis

Dr. Marta Muñoz Llamosas

Dr. Enrique Gómez Piñeiro

Firma

Firma

Valencia, Junio 2018 

A Martina y Ramón 

A mis padres, hermana y abuelos 

«Ideas do not last long. We must do something with them » «Las ideas no duran mucho. Hay que hacer algo con ellas» 



\section{AGRADECIMIENTOS}

A. Murillo-Ríos

Centro de Biotecnología Animal, Servicio Regional de Investigación y Desarrollo Agroalimentario (SERIDA), Gijón, 33394 
El presente trabajo de tesis doctoral no hubiese sido posible sin el apoyo y colaboración de todas las personas e instituciones que participaron oportuna y acertadamente en este proyecto. Por este motivo, a continuación quiero expresar mis más sinceros sentimientos de gratitud.

A mi director de tesis Dr. Enrique Gómez, por la oportunidad de formar parte de su equipo de trabajo. Bajo su dirección aprendí que el orden, la disciplina, la perseverancia y la rigurosidad son valores esenciales para desarrollar un trabajo de calidad. Gracias por todas las correcciones, las explicaciones, los consejos y la guía para culminar este trabajo.

A mi directora de tesis Dra. Marta Muñoz, por el tiempo, dedicación, ánimo y consejos de trabajo en el laboratorio y en la redacción científica. Me queda un gran ejemplo de lucha incansable por conseguir los objetivos que se plantean tanto en la vida académica como en la vida personal.

A Susana Carrocera Costa, por la dedicación, cordialidad y paciencia durante mi formación en el laboratorio de embriología, por el buen ambiente que brindas siempre, por las buenas influencias musicales y por todas las recomendaciones de la cultura asturiana.

A David Martín González por su trabajo técnico en los laboratorios, por dar guerra ante las adversidades del día a día en los trabajos experimentales y tener siempre un tiempo "pa echar unes rises". Gracias por todas las anécdotas de la "Llingua", de fútbol y de las tradiciones asturianas (de la Cuenca).

A la Dra. Marta Alonso y al Dr. Ángel Nistal del departamento de microscopía fotónica y proceso de imágenes de los Servicios Científico-Técnicos de la Universidad de Oviedo, por la valiosa colaboración técnica en los trabajos de microscopía confocal que componen esta tesis.

Al Dr. Félix Goyache y su grupo de trabajo (Isabel, Nuria é Iván) por todas las charlas de genética, estadística, antropología y política amenamente impartidas en estos cuatro años.

A mi tutor Dr. José Vicente Antón, por los ánimos para iniciar y cursar los estudios de doctorado en la UPV, sin tus palabras y guía durante los años de estudio previos quizá nunca me hubiera atrevido hacerlo. Gracias por la ayuda brindada con los trámites administrativos.

A Alberto Fernández Buznego y todo el equipo de operarios del Centro de Biotecnología Animal del SERIDA, por las amenas charlas, experiencias y bromas en medio del trabajo de campo.

Al servicio veterinario de la Cooperativa de Agricultores de Gijón, por la acertada colaboración en los trabajos de transferencia embrionaria. 
A la Secretaría Nacional de Educación Superior, Ciencia y Tecnología (SENESCYT), por los recursos económicos predoctorales.

Al Servicio Regional de Investigación y Desarrollo Agroalimentario (SERIDA), por permitirme desarrollar mi trabajo de investigación como becario externo en la institución.

Al Ministerio de Economía, Industria y Competitividad del gobierno de España, por el financiamiento de los proyectos en los cuales se han realizado los trabajos de esta tesis. También por las ayudas de movilidad para participar en las reuniones del proyecto "Producción in vitro de embriones de animales de interés veterinario" convocatoria 2016.

A la dirección del "Máster universitario en biología y tecnología de la reproducción" de la Universidad de Oviedo, por permitirme formar parte en su plantilla docente.

To the European COST- Action 16119, in vitro 3-D total cell guidance and fitness (Cellfit) by the funds to participate in the training school and by the promotion of interdisciplinary and multicultural networking.

A los compañeros(as) de estudio en el centro de biotecnología animal del SERIDA: Eva Correia, Begoña Menéndez, Pilar Nieto, Alejandro Vázquez y Cristina Blanco, por el apoyo, los ánimos y las experiencias compartidas.

A Marcia Ferráz, Manuel Revilla, Meriem Hamdi, Beatriz Fernández, Ma. Jesús Sánchez, Celia de Frutos y Marta Vázquez por compartir sus experiencias estudiantiles y profesionales, por sus consejos y su sincera amistad.

A Niccolo, Paula, Antonio, Mateo, Mark, Ana y Eli, por el gran año de intercambio Erasmus, por compartir la cultura de sus países de origen y por los irrepetibles momentos compartidos en Gijón.

A Javier, Alejandra, Rafa, Álvaro y Nerea por haberme hecho huésped exclusivo en su Gijón del alma con extensión hasta las islas Canarias, su tiempo y amistad hicieron que me sienta como en casa desde el primer momento.

A Isra, Danny y Django por la afición musical y su talento en los ensayos, me ayudaron en gran medida a renovar energías, tan necesarias para sobrellevar este trabajo.

Finalmente a toda mi familia, nada hubiera sido posible sin su apoyo incondicional. Sus valores y enseñanzas han sido pilares fundamentales para alcanzar mis objetivos en la vida. A Martina por el soporte en la convivencia, por tu manera de ver la vida y por ser una estupenda amiga, compañera y esposa. Sin olvidarme de la gran alegría y aventura que iniciamos junto Ramón, va por ustedes. 


\section{RESUMEN}

A. Murillo-Ríos

Centro de Biotecnología Animal, Servicio Regional de Investigación y Desarrollo Agroalimentario (SERIDA), Gijón, 33394 
En la última década, la producción de embriones bovinos in vitro se ha incrementado notablemente, convirtiéndose en la principal tecnología de embriones a escala mundial. En bovino, la producción de embriones in vitro incluye el diseño y preparación de medios de cultivo, los cuales son esenciales para dar soporte al desarrollo de ovocitos y embriones. Sin embargo, la producción de embriones in vitro aún continúa limitada por varios factores. El cultivo in vitro después de la fecundación es un período crítico para producir embriones de buena calidad y viabilidad. Además, el correcto desarrollo y mantenimiento de la gestación hasta el parto y la adecuada salud perinatal de los terneros están altamente correlacionados con los medios y sistemas de cultivo in vitro. En bovinos, el cultivo individual in vitro en condiciones definidas después de día-6 favorece el desarrollo embrionario y permite realizar diferentes análisis no invasivos del medio de cultivo. Por el contrario, los suplementos no definidos presentes en los medios de cultivo convencionales pueden reducir la repetibilidad de los análisis. Por lo tanto, el objetivo general de este trabajo de tesis doctoral fue optimizar un sistema de cultivo para mejorar la calidad y la viabilidad de embriones bovinos in vitro. Con este propósito se desarrollaron cuatro grupos de experimentos.

En primer lugar, evaluamos los efectos de la eliminación de proteína sobre el desarrollo de blastocitos durante un período corto de cultivo individual. La viabilidad del embrión a diferentes plazos fue analizada mediante supervivencia a la criopreservación y recuento diferencial de células embrionarias; porcentajes de gestación; y duración de la gestación, peso y morfometría de los terneros nacidos. Además, se realizó un análisis de expresión génica en blastocistos expandidos de Día-7 tanto antes como después de la criopreservación. De este 
capítulo se puede concluir que el cultivo de embriones individuales durante $24 \mathrm{~h}$ en un medio libre de proteína produce menos blastocistos pero aumenta los porcentajes de nacimiento después de la vitrificación y la transferencia a receptoras.

A continuación se abordó la evaluación de la viabilidad de los blastocistos expandidos producidos en función de la cinética del embrión y la restricción de proteína durante un periodo corto en cultivo individual. Así, las mórulas y los blastocistos tempranos de día 6 se cultivaron individualmente con y sin proteína durante $24 \mathrm{~h}$. El desarrollo y el contenido de lípidos se analizaron en blastocistos expandidos derivados de mórulas (M-XB) y de blastocistos tempranos (EB-XB). La expresión de genes implicados en el metabolismo lipídico, las respuestas al estrés y la apoptosis se analizaron en M-XB frescos y vitrificados, producidos con y sin proteína. Los índices de gestación, los porcentajes de nacimientos y el peso al nacimiento se registraron después de la transferencia de embriones. Los resultados indican que la cinética embrionaria y la vitrificación impactan en los fenotipos al nacimiento, al menos en el subconjunto de las terneras. Las alteraciones pueden involucrar la proteína exógena y la movilización de las reservas de lípidos.

Posteriormente, se investigó si una concentración muy baja de FCS (0.1\%) en cultivo desde el día 1 hasta el día 6 podría mejorar los porcentajes de blastocisto temprano (EB) y, a continuación, aumentar los porcentajes de blastocisto expandido $(\mathrm{XB})$ en día 7 después de un cultivo individual sin proteína. La calidad de los embriones producidos se evaluó en términos de supervivencia a la criopreservación, porcentaje de apoptosis, acumulación de lípidos y 
transferencia a receptoras. Se concluye en este capítulo que la concentración mínima de FCS mejora los porcentajes de EB en el Día 6, permitiendo obtener más XB después de $24 \mathrm{~h}$ de cultivo individual sin proteína. La calidad de los XB producidos con FCS es similar a los XB producidos con BSA en términos de apoptosis, acumulación de lípidos e índice de gestación.

Finalmente, el objetivo en el cuarto capítulo fue cuantificar la proteína total HDGF en el fluido uterino (FU) mediante multiple reaction monitoring (MRM), técnica que permite reconocer la proteína total. Además, analizamos los efectos de rHDGF en etapas embrionarias específicas con embriones bovinos de Día-6 cultivados in vitro con y sin proteína (BSA); y sobre la viabilidad de la preñez y los fenotipos de los terneros después de la transferencia de embriones a receptoras. Además, se cuantificó el ARNm de HDGF en células endometriales cocultivadas con un embrión macho o un embrión hembra. De este capítulo se puede concluir que el HDGF total cuantificado por MRM tendió a aumentar en el FU sin embriones, mientras que el sexo del embrión podría regular la expresión endometrial de HDGF. Sin embargo, se debe ser cauteloso con el uso de suplementos macromoleculares específicos en cultivo, ya que pueden contener el GF en estudio, como ocurre con la presencia de HDGF en la BSA comercial, lo que puede alterar los resultados de los experimentos. En última instancia, el uso de rHDGF es compatible con la gestación y el nacimiento de terneros normales. 


\section{ABSTRACT}

A. Murillo-Ríos

Centro de Biotecnología Animal, Servicio Regional de Investigación y Desarrollo Agroalimentario (SERIDA), Gijón, 33394 
In the last decade, the in vitro production (IVP) of bovine embryos has been increased notably becoming the leading embryo technology worldwide. In cattle, IVP of embryos included the design and preparation of culture media, which are essential to support the development of oocytes and embryos. However, IVP of embryos still continues limited by several factors. In vitro culture after fertilization stage is a critical period to produce embryos of good quality and viability. Furthermore, a correct gestation development, it normal maintenance up to parturition and a suitable perinatal health of calves are highly correlated with media and in vitro culture systems. In bovine, individual in vitro embryo culture in chemically defined conditions after Day-6 benefits embryo development and different non-invasive analyses of culture medium can be realized. In contrast, undefined supplements in classical culture media can reduce analytical reliability. Then, the general aim of this thesis was to optimize an embryo culture system in order to improve quality and viability of in vitro bovine embryos. With this purpose, four groups of experiments were developed. First, we evaluated the effects of protein removal in a short period of individual culture on blastocyst development. The embryo viability was analyzed at different terms through survival to cryopreservation and differential cell counts; pregnancy rates and gestation length, weight and morphometry of calves born. In addition, gene expression analysis was performed on Day-7 expanded blastocysts both before and after cryopreservation. From this chapter it may be concluded that individual embryo culture for $24 \mathrm{~h}$ in a protein-free medium, reduced Day-7 expanded blastocyst rates but improved birth rates after vitrification and transfer to recipients. 
Next, we evaluated the viability of produced expanded blastocyst in depends of embryo kinetics and protein restriction during a short step in individual culture. Thus, Day-6 morulae and early blastocysts were cultured individually with and without protein for $24 \mathrm{~h}$. Development and lipid content were analysed in expanded blastocysts derived from morulae (M-XB) and from early blastocysts (EB-XB). Expression of genes involved in lipid metabolism, stress responses and apoptosis was analysed in fresh and vitrified/warmed M-XB produced with and without protein. Pregnancy rates, birth rates and birthweight were recorded after transfer of embryos. The results indicate that embryonic kinetics and vitrification impact birth phenotypes, at least in females. Alterations might involve exogenous protein and mobilisation of lipid stocks.

Later, we investigated whether a very low FCS concentration (0.1\%) in culture from Day-1 to Day-6 would improve early blastocyst (EB) rates and, subsequently, increase expanded blastocyst (XB) rates on Day-7 after single culture in protein-free medium. The quality of embryos produced was evaluated in terms of survival to cryopreservation, apoptosis percentage, lipid accumulation and transfer to recipients. In conclusion, minute FCS concentration improves EB rates on Day-6 leading, after 24h of single culture without protein, to more XBs. The quality of XB produced with FCS compares well with XB produced with BSA in terms of apoptosis, lipid accumulation and pregnancy.

Finally, the aim of the last chapter was quantify total HDGF protein in uterine fluid (UF) by multiple reaction monitoring (MRM), and analysed effects of rHDGF on specific embryonic stages with Day-6 bovine embryos cultured in vitro with and without protein (BSA), and on pregnancy viability and calf 
phenotypes after embryo transfer to recipients. In addition, mRNA abundance of HDGF in endometrial cells co-cultured with one male or one female embryo was quantified. From this chapter it may be concluded that total HDGF quantified by MRM tended to increase in UF without embryos, and the endometrial expression of HDGF can be regulated by the embryonic sex. Furthermore, rHDGF acts selectively on specific embryonic stages, but care should be taken with specific macromolecular supplements in culture, as the GF under study can be present, as it happens with presence of HDGF in commercial BSA, and the experiment results can be altered. Ultimately, the use of rHDGF is compatible with pregnancy and birth of normal calves. 


\section{RESUM}

A. Murillo-Ríos

Centro de Biotecnología Animal, Servicio Regional de Investigación y Desarrollo Agroalimentario (SERIDA), Gijón, 33394 
En l'última dècada, la producció d'embrions bovins in vitro s'ha incrementat notablement, convertint-se en la principal tecnologia d'embrions a escala mundial. En boví, la producció d'embrions in vitro inclou el disseny i preparació de medis de cultiu, els quals són essencials per a donar suport al desenvolupament d'ovòcits i embrions. No obstant això, la producció d'embrions in vitro encara continua limitada per diversos factors. El cultiu in vitro, després de la fecundació, és un període crític per a produir embrions de bona qualitat i viabilitat. A més, el correcte desenvolupament i manteniment de la gestació fins al part i l'adequada salut perinatal dels vedells estan altament correlacionats amb els medis i sistemes de cultiu in vitro. En bovins, el cultiu individual in vitro en condicions definides després de día-6 afavoreix el desenvolupament embrionari i permet realitzar diferents anàlisis no invasius del medi de cultiu. Al contrari, els suplements no definits presents en els medis de cultiu convencionals poden reduir la repetibilitat dels anàlisis. Per tant, l'objectiu general d'este treball de tesi doctoral va ser optimitzar un sistema de cultiu per a millorar la qualitat i la viabilitat d'embrions bovins in vitro. Amb este propòsit es van plantejar quatre grups d'experiments.

En primer lloc, vam avaluar els efectes de l'eliminació de proteïna sobre el desenvolupament de blastocists durant un període curt de cultiu individual. La viabilitat de l'embrió a diferents terminis va ser analitzada per mitjà de la supervivència a la criopreservació i recompte diferencial de cèl-lules embrionàries; percentatges de gestació; i duració de la gestació, pes i morfometria dels vedells nascuts. A més, es va realitzar un anàlisi d'expressió gènica en blastocists expandits de dia-7 tant abans com després de la criopreservació. D'este capítol es pot concloure que el cultiu d'embrions 
individuals durant $24 \mathrm{~h}$ en un medi lliure de proteïna produeix menys blastocists però augmenta els percentatges de naixement després de la vitrificació i la transferència a receptores.

A continuació es va abordar l'avaluació de la viabilitat dels blastocists expandits produïts en funció de la cinètica de l'embrió i la restricció de proteïna durant un període curt en cultiu individual. Així, les mòrules i els blastocists primerencs de dia 6 es van cultivar individualment amb i sense proteïna durant $24 \mathrm{~h}$. El desenvolupament i el contingut de lípids es van analitzar en blastocists expandits derivats de mòrules (M- XB) i de blastocistos primerencs (EB-XB). L'expressió de gens implicats en el metabolisme lipídic, les respostes a l'estrès i l'apoptosi es van analitzar en M-XB frescs i vitrificats, produïts amb i sense proteïna. Els índexs de gestació, els percentatges de naixements i el pes al naixement es van registrar després de la transferència d'embrions. Els resultats indiquen que la cinètica embrionària i la vitrificació impacten en els fenotips al naixement, almenys en el subconjunt de les vedelles. Les alteracions poden involucrar la proteïna exògena i la mobilització de les reserves de lípids.

Posteriorment, es va investigar si una concentració molt baixa de FCS (o.1\%) en cultiu des del dia 1 fins al dia 6 podria millorar els percentatges de blastocists primerenc (EB) i, a continuació, augmentar els percentatges de blastocists expandits $(\mathrm{XB})$ en dia 7 després d'un cultiu individual sense proteïna. La qualitat dels embrions produïts es va avaluar en termes de supervivència a la criopreservació, percentatge d'apoptosi, acumulació de lípids i transferència a receptores. Es conclou en este capítol que la concentració mínima de FCS millora els percentatges d'EB en el Dia 6, permetent obtindre més XB després 
de $24 \mathrm{~h}$ de cultiu individual sense proteïna. La qualitat dels XB produïts amb FCS és semblant als XB produïts amb BSA en termes d'apoptosi, acumulació de lípids e índex de gestació.

Finalment, l'objectiu en el quart capítol va ser quantificar la proteïna total HDGF en el fluid uterí (FU) per mitjà de multiple reaction monitoring (MRM), tècnica que permet reconèixer la proteïna total. A més, analitzem els efectes de rHDGF en etapes embrionàries específiques amb embrions bovins de Dia-6 cultivats in vitro amb i sense proteïna (BSA); i sobre la viabilitat del prenyat i els fenotips dels vedells després de la transferència d'embrions a receptores. A més, es va quantificar l'ARNm de HDGF en cèl-lules endometrials cocultivades amb un embrió mascle o un embrió femella. D'este capítol es pot concloure que el HDGF total quantificat per MRM va tendir a augmentar en l'FU sense embrions, mentre que el sexe de l'embrió podria regular l'expressió endometrial de HDGF. No obstant això, s'ha de ser cautelós amb l'ús de suplements macromoleculars específics en cultiu, ja que poden contindre el GF en estudi, com ocorre amb la presència de HDGF en la BSA comercial, la qual cosa pot alterar els resultats dels experiments. En última instància, l'ús de rHDGF és compatible amb la gestació i el naixement de vedells normals. 


\section{ABREVIATURAS:}

aaci

aminoácidos esenciales y no esenciales, citrato, mioinositol

ADN ácido desoxirribonucleico

AGE activación del genoma embrionario

ARNm ácido ribonucleico mensajero

ATF4 activating transcription factor 4

ATP adenosin trifosfato

$B A X$ bcl-2-associated $\mathrm{X}$ protein

$\mathrm{Bb}$ bisbenzimida

BSP proteínas del plasma seminal

BSA albumina sérica bovina

${ }^{\circ} \mathrm{C}$ grados centígrados

cAMP adenosín monofosfato cíclico

CIV cultivo in vitro

COCs complejos cumulo-ovocito

DAPI 4 ',6-diamino-2-fenilindol

DDIT3 DNA-damage-inducible transcript 3

EB blastocisto temprano

FIV fecundación in vitro

FCS suero fetal bovino

FU fluido uterino

G6PD glucose-6-phosphate dehydrogenase

GFs factores de crecimiento

$\mathrm{g} \mathrm{L}^{-1} \quad$ gramos por litro

GPX1 glutathione peroxidase 1

HDGF hepatoma derived growth factor

IA inseminación artificial

IETS international embryo transfer society

IFN- $\tau$ interferón tau

$I G F 2 R$ insulin-like growth factor 2 receptor

IP yoduro de propidio
M mórula

MCI masa celular interna

MIV maduración in vitro

mOsM miliosmomoles

MOET multiple ovulation embryo transfer

mol L ${ }^{-1} \quad$ moles por litro

MRM multiple reaction monitoring

NR nile red

OPU ovum pick-up

PKA proteína quinasa $\mathrm{A}$

PTK tirosina quinasas

Ptyr-Ptase tirosina fosfatasas

PVA polivinil alcohol

SAC adenil ciclasa soluble

SLC2A3 solute Carrier Family 2 member 3

SOD2 superoxide dismutase 2, Mitochondrial (formerly MnSOD)

SOF medio sintético de fluido de oviducto

TD transferencia directa

TE tecnologías embrionarias

TEM transición materno-

embrionaria

TF trofectodermo

TUNEL terminal deoxynucleotidyl transferase dUTP nick end labeling

$\mu \mathrm{L} \quad$ microlitro

v/c vitrificación/calentamiento

$\mathrm{XB}$ blastocisto expandido

$\mathrm{ZP} \quad$ zona pelúcida 


\section{ÍNDICE DE CONTENIDOS}




\section{INTRODUCCIÓN GENERAL 1}

1.1. Tecnologías embrionarias aplicadas en bovinos 2

$\begin{array}{ll}\text { 1.2. Producción de embriones bovinos in vitro } & 7\end{array}$

$\begin{array}{ll}\text { 1.2.1. Maturación in vitro } & 7\end{array}$

$\begin{array}{lr}\text { 1.2.2. Fecundación in vitro } & 9\end{array}$

$\begin{array}{ll}\text { 1.2.3. Cultivo in vitro } & 13\end{array}$

1.2.4. Características de los medios de cultivo in vitro para bovinos 16

1.2.5. Factores de crecimiento para el cultivo in vitro de $\begin{array}{ll}\text { embriones bovinos } & 20\end{array}$

1.2.6. Cocultivo de células endometriales y embriones 21

1.3. Criopreservación de embriones producidos in vitro 23

$\begin{array}{ll}\text { 1.3.1. Congelación lenta } & 24\end{array}$

$\begin{array}{ll}\text { 1.3.2. Vitrificación } & 25\end{array}$

1.4. Evaluación de la calidad y viabilidad de embriones bovinos

$\begin{array}{ll}\text { producidos in vitro } & 27\end{array}$

$\begin{array}{ll}\text { 1.4.1. Morfología } & 28\end{array}$

1.4.2. Recuento total y diferencial de células embrionarias 30

1.4.3. Apoptosis y daño celular 32

1.4.4. Contenido de lípidos intracelulares 33

1.4.5. Prueba de supervivencia a la criopreservación 35

1.4.6. Expresión génica 36

$\begin{array}{ll}\text { 1.4.7. Dimorfismo sexual } & 37\end{array}$

1.5. La viabilidad del embrión en las receptoras 41

1.5.1. Establecimiento de la gestación 41

1.5.2. Pérdidas embrionarias tempranas y aborto 43 
1.5.3. Resultados perinatales con embriones producidos in vitro $\quad 45$

1.5.4. Salud perinatal de terneros producidos in vitro 47

$\begin{array}{ll}\text { 1.6. Referencias } & 49\end{array}$

2. OBJETIVOS 70

\section{CAPÍTULO I}

Short- and long-term outcomes of the absence of protein during bovine blastocyst formation in vitro

3.1. Introduction 75

$\begin{array}{ll}\text { 3.2. Material and Methods } & 77\end{array}$

3.2.1. In vitro embryo production 77

$\begin{array}{ll}\text { 3.2.2. Differential cell counts } & 79\end{array}$

$\begin{array}{ll}\text { 3.2.3. Vitrification of embryos } & 79\end{array}$

3.2.4. Warming and survival of vitrified embryos 80

3.2.5. Oestrus synchronization of recipients, embryo transfer and $\begin{array}{ll}\text { pregnancy and birth monitoring } & 80\end{array}$

3.2.6. Gene expression analysis: RNA extraction, reverse transcription and quantification of mRNA $\begin{array}{lr}\text { transcript abundance } & 80\end{array}$

3.2.7. Embryo sexing by PCR 83

3.2.8. Statistical analysis 83

3.3. Results 84

3.3.1. Embryo development 84

3.3.2. Differential cell counts 85

3.3.3. In vitro survival of vitrification and warming 85

3.3.4. Embryo transfer to recipients and birth 86

3.3.5. Gene expression study 87 
3.3.6. Sex analysis of Day-7 blastocysts

3.4. Discussion

\section{CAPÍTULO II}

Protein in culture and endogenous lipid interact with embryonic stages in vitro to alter calf birthweight after embryo vitrification and warming

4.1. Introduction

4.2. Material and Methods

4.2.1. Embryo production

4.2.2. Embryo sexing by PCR

4.2.3. Vitrification of embryos for transfer

4.2.4. Lipid and cell nuclei staining

4.2.5. RNA analysis

4.2.6. Embryo transfer, pregnancy diagnosis and calf phenotyping

4.2.7. Experimental design

4.2.7.1. Experiment 1: Day-7 embryo development patterns and sex ratio after individual culture in the presence or absence of protein during $24 \mathrm{~h}$

4.2.7.2. Experiment 2: Analysis of gene expression after individual culture in the presence or absence of protein

4.2.7.3. Experiment 3: Long-term effects of protein removal and development patterns 
$\begin{array}{lr}\text { 4.3. Results } & 117\end{array}$

4.3.1. Embryo development in individual culture 117

4.3.2. Embryo sex ratio 119

$\begin{array}{ll}\text { 4.3.3. Lipid content study } & 119\end{array}$

4.3.4. Gene expression study 122

4.3.5. Embryo transfer, pregnancy, birth and calf phenotypes 125

$\begin{array}{lr}\text { 4.4. Discussion } & 128\end{array}$

$\begin{array}{lr}\text { 4.5. References } & 134\end{array}$

\section{CAPÍTULO III}

Low serum concentration in bovine embryo culture enhances early blastocyst rates on Day- 6 with quality traits in the expanded blastocyst stage similar to BSA-cultured embryos

5.1. Introduction

5.2. Material and Methods

5.2.1. Oocyte collection and in vitro maturation (IVM)

5.2.2. Sperm preparation and in vitro fertilization (IVF)

5.2.3. In vitro culture (IVC)

5.2.4. Embryo vitrification, warming and in vitro survival

5.2.5. Apoptosis in blastocysts: TUNEL assay

5.2.6. Lipids and cell nuclei staining and quantification

5.2.7. Estrus synchronization of recipients, embryo transfer and pregnancy diagnosis

5.2.8. Experimental design

5.2.8.1. Experiment 1: FCS $(0.1 \%)$ supplementation and embryo development

5.2.8.2. Experiment 2: FCS $(0.1 \%)$ supplementation 
and in vitro survival to cryopreservation

5.2.8.3. Experiment 3: FCS $(0.1 \%)$ supplementation and apoptosis rates of vitrified/warmed Day-7 expanded blastocysts

5.2.8.4. Experiment 4: FCS (0.1\%) supplementation and lipid contents of Day-6 morulae and Day-7 blastocyst expanded

5.2.9. Statistical analysis

5.3.2. In vitro survival to vitrification and warming

5.3.3. Apoptosis and total cell numbers

5.3.4. Lipid quantification study

5.3.5. Embryo transfer and pregnancies

5.4. Discussion

5.5. References

\section{CAPÍTULO IV}

Hepatoma-derived growth factor: Protein quantification in uterine fluid, gene expression in endometrial-cell culture and effects on in vitro embryo development, pregnancy and birth

6.1. Introduction

6.2. Material and Methods

6.2.1. Embryo production

6.2.2. Vitrification of embryos for transfer

6.2.3. Animals and embryo transfer (ET) for uterine fluid collection 
6.2.5. Multiple reaction monitoring (MRM) for HDGF contents in uterine fluid

6.2.6. Identification of HDGF in BSA supplements by western blot

6.2.7. Endometrial cell and embryo co-culture

6.2.8. Gene expression of HDGF in epithelial and stromal endometrial cell culture

6.2.9. Experimental design

6.2.9.1. Experiment 1: development of individually cultured morulae and early blastocysts in the presence of rHDGF

6.2.9.2. Experiment 2: targeted HDGF protein quantification in UF and BSA supplement

6.2.9.3. Experiment 3: influence of embryonic sex on gene expression of HDGF in cultured endometrial cells

6.2.9.4. Experiment 4: pregnancy rates and birth measurements after transfer of embryos produced with rHDGF

6.2.10. Statistical analysis

6.3.2. HDGF contents in uterine fluid

6.3.3. HDGF identification in BSA extracts

6.3.4. Pregnancy and birth rates, and calf measurements, of embryos cultured with rHDGF 
6.4. Discussion

6.5. References

7. DISCUSIÓN GENERAL

7.1. Restricción de proteína y desarrollo de embriones

7.2. Morfología y recuento diferencial de células del blastocisto después de la restricción de proteína 205

7.3. Restricción de proteína y supervivencia a la criopreservación 206

7.4. Contenido de lípidos intracelulares después de la restricción de proteína

7.5. Expresión génica tras la restricción de proteína 208

7.6. Restricción de proteína y dimorfismo sexual 210

7.7. Gestación y resultados perinatales 212

7.8. Referencias 216

8. CONCLUSIONES 


\section{ÍNDICE DE FIGURAS}




\section{INTRODUCCIÓN GENERAL}

Figura 1.1. Producción mundial de embriones bovinos in vivo (MOET) e $\mathbf{4}$ in vitro entre el año 1997 y 2016.

Figura 1.2. Clasificación de ovocitos bovinos recuperados de ovarios antes del proceso de maduración in vitro.

Figura 1.3. Esquema de los procesos intracelulares inducidos por la heparina durante la capacitación de espermatozoides bovinos.

Figura 1.4. Desarrollo embrionario bovino y activación del genoma embrionario

Figura 1.5. Esquema de enfriamiento y zonas críticas de daño celular durante la criopreservación.

Figura 1.6. Diferentes estadios de embriones bovinos producidos in vitro e in vivo

Figura 1.7. Acumulación de lípidos intracelulares en un blastocisto expandido bovino producido in vitro y representación esquemática de la composición de las gotas de lípidos

\section{CAPÍTULO I}

Figure 3.1. Relative abundance of mRNA transcribed from genes representing metabolism, oxidative stress, imprinting mechanisms and endoplasmic reticulum stress performed on pools of Day-7 fresh expanded blastocysts and on pools of hatched blastocysts that survived $24 \mathrm{~h}$ in vitro after vitrification and warming of Day-7 expanded blastocysts derived from Day- 6 embryos cultured individually in $12 \mu \mathrm{L}$ of synthetic oviduct fluid medium with protein or without protein

\section{CAPÍTULO II}

Figure 4.1. Lipid content per embryonic cell in Day-6 morulae and Day7 expanded blastocysts cultured with or without protein from Day 6 to Day 7

Figure 4.2. Lipid granules per embryonic cell counted in Day-7 expanded bovine blastocysts following single culture of Day-6 morulae or early blastocysts in SOF with protein or without protein

Figure 4.3. Average cell abundance of lipid droplets $<2 \mu \mathrm{m}$ in diameter in Day-7 expanded bovine blastocysts following single culture of Day-6 morulae or early blastocysts in SOF with 
protein or without protein

Figure 4.4. Representative three-dimensional reconstructions of confocal datasets showing lipid droplets stained with Nile red in a Day-7 bovine expanded blastocyst

Figure 4.5. Real-time PCR quantification of relative abundance of transcripts from genes involved in lipid fatty-acid metabolism in Day-7 fresh expanded blastocysts derived from Day-6 morulae cultured for $24 \mathrm{~h}$ with or without protein

Figure 4.6. Real-time PCR quantification of relative abundance of transcripts from genes involved in metabolism, lipid oxidative metabolism, antioxidative and stress defence and apoptosis in Day-7 fresh expanded blastocysts derived from Day-6 morulae cultured for $24 \mathrm{~h}$ with or without protein

Figure 4.7. Birthweight on a per bull basis of calves born after transfer of Day-7 IVP vitrified-warmed embryos whose development stages on Day 6 were monitored as compact morulae or early blastocysts

\section{CAPÍTULO III}

Figure 5.1. Experimental design

Figure 5.2. (a) Effects of serum (FCS) in culture up to Day-6 and developmental stage on Day-6, on total cell numbers and apoptosis percentages within hatched blastocysts surviving in culture after vitrification/warming of Day-7 expanded blastocysts. (b) Representative photomicrographs of single Z-axis confocal section of hatched blastocysts after vitrification/warming of expanded blastocysts produced in $\mathrm{mSOF}+6 \mathrm{mg} \mathrm{mL}^{-1}$ BSA with FCS up to Day- 6 or without FCS up to Day-6, and after one-day single culture without protein from Day-6 morula or from Day-6 early blastocyst

Figure 5.3. (a) Lipid droplets number and sizes per cell counted in fresh expanded blastocysts from culture with FCS up to Day-6 or without FCS up to Day-6, from Day-6 morula or from Day-6 early blastocyst (b) Representative three-dimensional reconstructions (frontal view) of confocal datasets showing lipid droplets stained with Nile Red in fresh expanded blastocysts produced in mSOF $+6 \mathrm{mg} \mathrm{mL}^{-1}$ BSA with FCS up to Day-6 or without FCS up to Day-6, and after one-day single culture without protein from Day-6 morula or from Day-6 early blastocyst 


\section{CAPÍTULO IV}

Figure 6.1. Western blot analysis of HGDF in bovine cold-precipitated 188 serum albumin and bovine fatty-acid-free serum albumin

Figure 6.2. Quantitative real-time PCR analysis of HDGF relative 190 expression in epithelial cells cultured for $48 \mathrm{~h}$ with one single male embryo, one single female embryo or no embryos 


\section{ÍNDICE DE TABLAS}




\section{CAPÍTULO I}

Table 3.1. Details of primers used for qPCR

Table 3.2. In vitro development of Day-6 embryos produced in group culture with SOFaaci with BSA and subsequently cultured individually in $12-\mu \mathrm{L}$ drops of SOFaaci with protein or without protein up to Day 8

Table 3.3. Differential cell counts in Day-8 expanded blastocysts cultured individually from Day 6 to Day 8 in drops of SOFaaci with protein or without protein

Table 3.4. In vitro survival after vitrification and warming of Day-7 and Day-8 bovine expanded blastocysts that were cultured individually in synthetic oviduct fluid medium with protein or without protein from Day 6 onwards

Table 3.5. Bodyweight, calves with bodyweight larger than $50 \mathrm{~kg}$, height at withers, thorax circumference, gestation length and average fetal daily weight gain of IVP calves born after transfer of bovine vitrified-warmed Day-7 expanded blastocysts derived from Day- 6 embryos cultured individually in $12 \mu \mathrm{L}$ of synthetic oviduct fluid medium with protein or without protein

Table 3.6. Embryo transfers performed per bull, with expression of Day-40 pregnancies and miscarriage attained

\section{CAPÍTULO II}

Table 4.1. Oligonucleotides used for real-time PCR gene expression $1 \mathbf{1 1 3}$ analysis

Table 4.2. In vitro blastocyst development rates of Day-6 morulae and early blastocysts cultured individually in $12 \mu \mathrm{L}$ drops of SOF containing amino-acids, citrate and myo-inositol with (+; $\left.6 \mathrm{mg} \mathrm{mL}^{-1} \mathrm{BSA}\right)$ or without $\left(-; 0.5 \mathrm{mg} \mathrm{mL}^{-1} \mathrm{PVA}\right.$ replacing BSA) protein up to Day 8

Table 4.3. Expanded blastocyst sex ratio (percent males) according to their Day- 6 origin from the morula or the early blastocyst stages and subsequent individual culture in $12 \mu \mathrm{L}$ drops of SOF with $\left(+; 6 \mathrm{mg} \mathrm{mL}^{-1} \mathrm{BSA}\right)$ or without $\left(-; 0.5 \mathrm{mg} \mathrm{mL}^{-1}\right.$ $P V A$ replacing $B S A$ ) protein

Table 4.4. Pregnancy, calving and miscarriage rates after transfer of bovine vitrified Day-7 expanded blastocysts in terms of their 
Day-6 origin from the morula or the early blastocyst stage and subsequent individual culture in $12-\mu \mathrm{L}$ drops of SOF with $\left(+; 6 \mathrm{mg} \mathrm{mL}^{-1} \mathrm{BSA}\right)$ or without $\left(-; 0.5 \mathrm{mg} \mathrm{mL}^{-1}\right.$ PVA replacing $B S A)$ protein

Table 4.5. Progesterone increases from Day-0 up to Day-7 in recipients transferred with Day-7 expanded blastocysts in terms of their Day- 6 origin from the morula or the early blastocyst stage and their pregnancy status on Day-40

Table 4.6. Progesterone increases from Day-0 up to Day-7 in recipients transferred with Day- 7 expanded blastocysts in terms their culture with or without protein from Day-6 onwards and their pregnancy status on Day-40

Table 4.7. Weight and morphometry of calves born after transfer of bovine vitrified-warmed Day-7 expanded blastocysts in terms of their Day- 6 origin from the morula or the early blastocyst stage

Table 4.8. Weight and morphometry of female calves born after transfer of bovine vitrified-warmed Day-7 expanded blastocysts according to their Day- 6 origin from the morula or the early blastocyst stage

Table 4.9. Weight and morphometry of calves born after transfer of bovine fresh vs. vitrified/warmed Day-7 expanded blastocysts in terms of their Day-6 origin from the morula or the early blastocyst stage and subsequent individual culture in $12-\mu \mathrm{L}$ of SOF containing protein $\left(6 \mathrm{mg} \mathrm{mL}^{-1} \mathrm{BSA}\right)$

\section{CAPÍTULO III}

Table 5.1. Morula and early blastocyst rates on Day- 6 after culture in $\mathrm{mSOF}+6 \mathrm{mg} \mathrm{mL}^{-1}$ BSA in groups with or without $0.1 \%$ fetal calf serum (FCS)

Table 5.2. $\quad$ In vitro development of Day-6 morulae and early blastocysts produced in $\mathrm{mSOF}+6 \mathrm{mg} \mathrm{mL} \mathrm{m}^{-1} \mathrm{BSA}$ in groups with or without $0.1 \%$ FCS, and after single culture without protein up to Day-7

Table 5.3. In vitro survival after vitrification/warming of Day-7 bovine expanded blastocysts derived from morulae and early blastocysts produced in mSOF $+6 \mathrm{mg} \mathrm{mL}^{-1} \mathrm{BSA}$ with or without $0.1 \%$ FCS from Day- 1 to Day- 6 after one-day single culture without protein 
Table 5.4. Descriptive Day-40 and Day-60 pregnancy status of heifers transferred with embryos cultured from Day-1 to Day-6 in $\mathrm{mSOF}+6 \mathrm{mg} \mathrm{mL}^{-1} \mathrm{BSA}$, with or without $0.1 \% \mathrm{FCS}$ and after one-day single culture without protein

\section{CAPÍTULO IV}

Table 6.1. Sequence of peptides from bovine hepatoma-derived 179 growth factor detected in the multiple reaction monitoring study and their position in the protein

Table 6.2. In vitro development of bovine morulae and early blastocysts cultured individually from day 6 to day 8 in droplets of synthetic oviduct fluid with BSA containing 100 $\mathrm{ng} \mathrm{mL}{ }^{-1}$ recombinant HDGF (rHDGF)

Table 6.3. In vitro development of bovine morulae and early blastocysts cultured individually from day 6 to day 8 in droplets of synthetic oviduct fluid with PVA containing 100 $\mathrm{ng} \mathrm{mL} \mathrm{m}^{-1}$ recombinant HDGF (rHDGF)

Table 6.4. Pregnancy and calving rates of recipients transferred 1-2 times and 3-4 times with bovine vitrified Day-7 expanded blastocysts individually cultured from Day-6 to Day-7 in 12 $\mu \mathrm{L}$ of synthetic oviduct fluid medium $+0.5 \mathrm{mg} \mathrm{mL}^{-1}$ PVA with or without rHDGF (100 ng mL $\mathrm{m}^{-1}$ )

Table 6.5. Weight and morphometry of calves born after transfer of bovine vitrified/warmed Day-7 expanded blastocysts cultured individually with or without r-HDGF (100 $\mathrm{ng} \mathrm{mL} \mathrm{m}^{-1}$ ) from Day-6 to Day-7 


\section{1 | INTRODUCCIÓN GENERAL}

A. Murillo-Ríos

Centro de Biotecnología Animal, Servicio Regional de Investigación y Desarrollo Agroalimentario (SERIDA), Gijón, 33394 


\subsection{Tecnologías embrionarias aplicadas en bovinos}

El proceso de domesticación del ganado bovino (Bos taurus y Bos indicus) hace $\approx 11.000$ años, provocó que la reproducción de estos animales pasase a estar controlada selectivamente por los seres humanos (Beja-Pereira y cols., 2006). Más tarde, las tecnologías reproductivas desarrolladas en el ganado bovino permitieron perfeccionar el rendimiento de los sistemas de producción, mejorando sustancialmente su rentabilidad y su eficiencia.

En el ganado bovino, las tecnologías reproductivas embrionarias constituyen una de las herramientas más importantes para la investigación científica y la producción animal. Así, las tecnologías embrionarias (TE) han contribuido a mejorar notablemente la comprensión de los mecanismos fisiológicos básicos de la biología del desarrollo de los mamíferos, incluido el ser humano. Por otra parte, las TE aplicadas a la producción bovina, han permitido mejorar la capacidad reproductiva de la hembra y los esquemas de selección genética en las industrias láctea y cárnica.

La técnica de ovulación múltiple y transferencia de embriones (MOET, del inglés Multiple Ovulation and Embryo Transfer) y la técnica de producción in vitro de embriones son las TE más importantes dentro de los programas de reproducción bovina. El uso y la aplicación de las técnicas MOET y producción in vitro de embriones bovinos ha hecho posible desarrollar otras técnicas más complejas (por ejemplo clonación, transgénesis, producción de células madre) de gran interés en biomedicina (Bogliotti y cols., 2018).

La técnica MOET consiste en la aplicación de un tratamiento hormonal para estimular los ovarios de una hembra donante para inducir una ovulación 
múltiple. Una vez en celo, la donante es inseminada artificialmente y una semana más tarde se recogen los embriones producidos mediante lavado de los cuernos uterinos. Los embriones recogidos son después clasificados por su calidad y estadío para ser transferidos a receptoras sincronizadas o para criopreservarlos (Thibier, 2005).

Los programas MOET han hecho posible incrementar la intensidad de selección y reducir el intervalo generacional, acelerando la mejora genética en los esquemas de selección bovina. Sin embargo, desde su desarrollo original el rendimiento permanece prácticamente invariable, pues el número de embriones transferibles obtenidos por donante es reducido (promedio de 6.5; Perry, 2016). Otras desventajas incluyen la alta variabilidad de la respuesta a los tratamientos hormonales de ovulación múltiple (aproximadamente un $20 \%$ de las donantes no producen embriones), la necesidad de un amplio periodo de reposo entre cada tratamiento y la falta de eficiencia cuando se utiliza semen sexado (Hasler, 2003; Mikkola y cols., 2017).

Desde la década de los 80 hasta 2015, los programas MOET representaron la TE más aplicada en el ganado bovino en un contexto global (Blondin, 2015). Por otra parte, el número de embriones producidos in vitro (PIV) se ha incrementado considerablemente desde los años 90 (Blondin, 2015), especialmente como resultado de las mejoras desarrolladas en el cultivo embrionario. Así, durante el año 2016 según los datos publicados por la sociedad internacional de transferencia de embriones (IETS), 668.837 embriones bovinos fueron PIV a escala mundial; superando por primera vez al número de embriones transferibles producidos in vivo mediante la técnica MOET (Perry, 2016) (Fig. 1.1). 


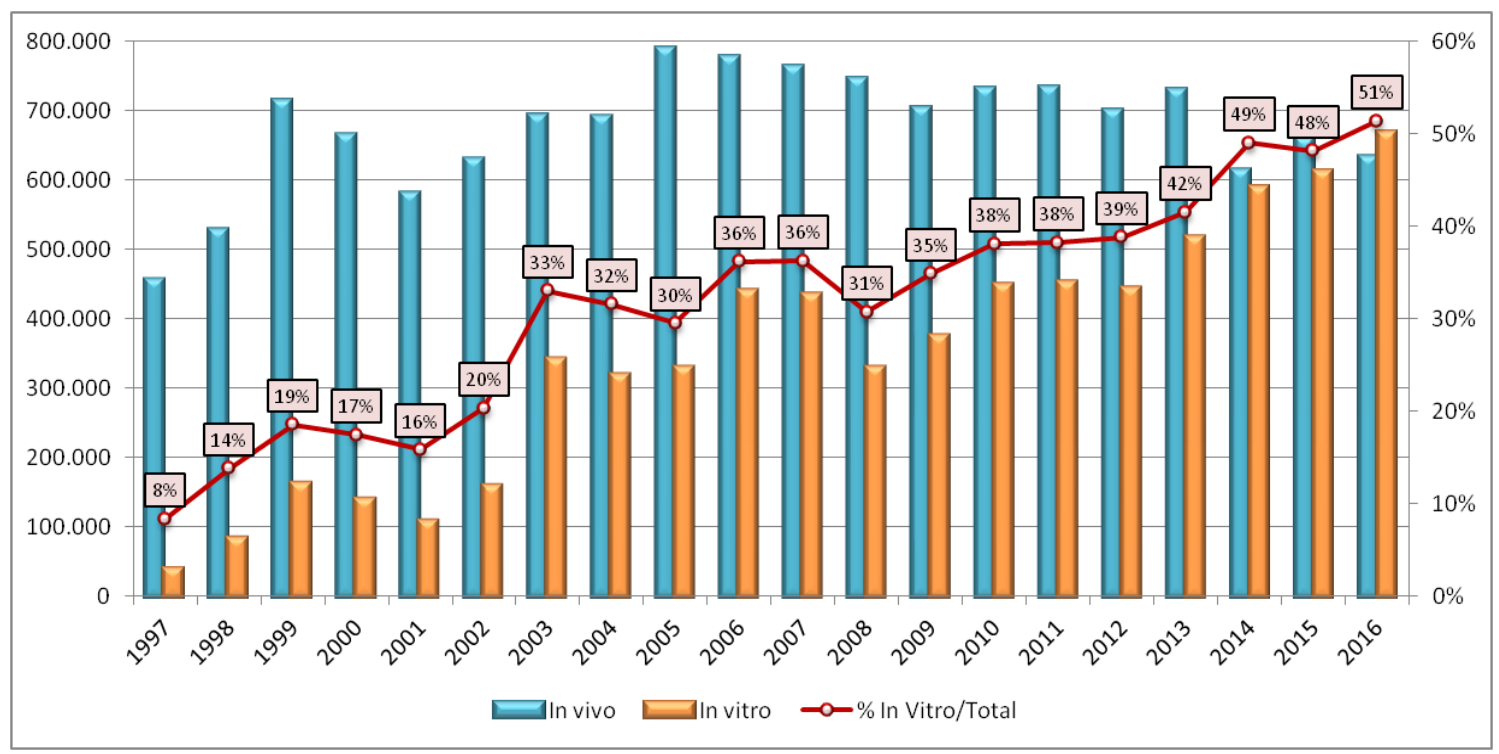

Fig. 1.1. Producción mundial de embriones bovinos in vivo (MOET) e in vitro entre el año 1997 y 2016. Adaptado de Blondin, 2015; y Perry, 2015, 2016.

Una de las estrategias para producir mejores embriones in vitro es tratar de imitar el ambiente y los eventos de maduración y fertilización ovocitaria, y desarrollo embrionario temprano, que ocurren en el trato reproductivo femenino. Los embriones bovinos in vitro pueden ser producidos a partir de ovocitos obtenidos de donadoras vivas, mediante la técnica de Ovum Pick-Up (OPU; Merton, 2003), o a partir de ovocitos de hembras sacrificadas mediante la punción de los ovarios obtenidos en el matadero (Galli y cols., 2003).

Los protocolos de OPU para producir embriones bovinos in vitro pueden ser aplicados en una misma donadora una 0 incluso dos veces por semana haciendo que el número de crías que se puede obtener por unidad de tiempo sea superior a los conseguidos mediante la técnica MOET. Los embriones bovinos PIV se pueden obtener también mediante OPU de hembras gestantes (hasta el primer trimestre de gestación), animales tras dos o tres semanas de posparto, novillas pre-púberes o animales con ciertas patologías en el tracto 
uterino (Baruselli, 2016). De igual manera, los ovocitos recuperados se pueden fecundar con espermatozoides de diferentes toros, lo que aumenta la variabilidad genética en la progenie y reduce los porcentajes de consanguinidad. Además, la producción in vitro de embriones bovinos permite un uso más eficiente del semen sexado, ya que con una sola pajuela de semen se puede fecundar un amplio número de ovocitos (Pontes y cols., 2010; Morotti y cols., 2014).

A pesar de las ventajas y el potencial de la producción in vitro de embriones bovinos, aun se busca mejorar los porcentajes de producción de embriones viables. Cuando se usan ovocitos madurados in vivo se pueden obtener porcentajes de blastocistos de hasta el $80 \%$ (Blondin y cols., 2002). No obstante, cuando los ovocitos son madurados in vitro sólo entre el $30-40 \%$ de los ovocitos tratados alcanzan el estadio de blastocisto (Lonergan y Fair, 2014). Los embriones PIV son más sensibles a la criopreservación que los embriones desarrollados en el animal vivo (Rizos y cols., 2008; Sudano y cols., 2011). Los patrones de expresión génica también se encuentran alterados en los embriones PIV en comparación con los embriones producidos in vivo (Lonergan, 2003; Gad, 2012). Además, se han observado cambios en el transcriptoma de embriones bovinos in vitro producidos en diferentes condiciones de cultivo (Nieman, 2000; Cagnone y cols., 2012; van der Weijden y cols., 2017).

De igual manera, los índices de gestación que se obtienen con embriones PIV transferidos a receptoras son más bajos que los obtenidos con embriones producidos in vivo (Pontes y cols., 2009; Siqueira y cols., 2009). Además, los 
embriones bovinos PIV ocasionan elevados porcentajes de abortos tempranos (Stewart y cols., 2011), anormalidades fetales (Young, 1998; Farin y cols., 2006), distocia y mortalidad perinatal (van Wagtendonk-de Leeuw y cols., 1998; Farin, 2010; Bonilla y cols., 2014).

En vacas de leche, la calidad del folículo preovulatorio ha sido identificada como una de las principales causas de las pérdidas embrionarias al inicio de la gestación (Lonergan y cols., 2016; Wiltbank y cols., 2016). En este sentido, el proceso de maduración in vitro (MIV) determina en gran medida el éxito de la fertilización y el posterior desarrollo embrionario (Nuttinck y cols., 2017; Botigelli y cols., 2017).

Varios estudios realizados en mamiferos han demostrado que la calidad de los embriones bovinos PIV está asociada a las condiciones del cultivo, durante los estadíos de zigoto y blastocisto (Rizos y cols., 2002a; Fleming y cols., 2015; Hansen $y$ cols., 2015). De esta manera, el cultivo, que sigue a la fecundación, también es un periodo crítico en el proceso de producción de embriones bovinos in vitro, e incide directamente en la calidad del embrión y también en la salud del feto y del ternero nacido (Fleming y cols., 2015; Duranthon y cols., 2018). La calidad de los embriones PIV todavía es hoy deficiente en comparación con sus homólogos in vivo. Por lo tanto, es esencial optimizar los sistemas de PIV de embriones bovinos no solo para producir mayores porcentajes de blastocitos, sino, lo que es más importante, blastocistos de mejor calidad capaces de producir gestaciones a término con una descendencia saludable. 


\subsection{Producción de embriones bovinos in vitro}

Generalmente en bovino, la producción de embriones in vitro implica tres pasos secuenciales: la MIV de ovocitos, la fecundación in vitro (FIV) de los ovocitos madurados y el cultivo in vitro (CIV) de los ovocitos fecundados hasta el estadio de blastocisto. En cada paso de la producción de embriones in vitro, las condiciones físico-químicas de los medios MIV, FIV y CIV deben optimizarse para permitir la maduración, capacitación e interacción de gametos, así como el desarrollo de embriones.

\subsubsection{Maduración in vitro}

Los ovocitos inmaduros se pueden obtener de vacas y novillas vivas mediante OPU ó a partir de ovarios recogidos en matadero. Los folículos antrales (3-8 $\mathrm{mm}$ de diámetro) son aspirados y los complejos cumulo-ovocito (COCs, del inglés cumulus-oocyte complex) que se obtienen se seleccionan en la práctica por su morfología. Así, únicamente los ovocitos que están rodeados de una a tres o más capas de células del cumulus y que presentan un citoplasma homogéneo se escogen para MIV (Fig. 1.2).

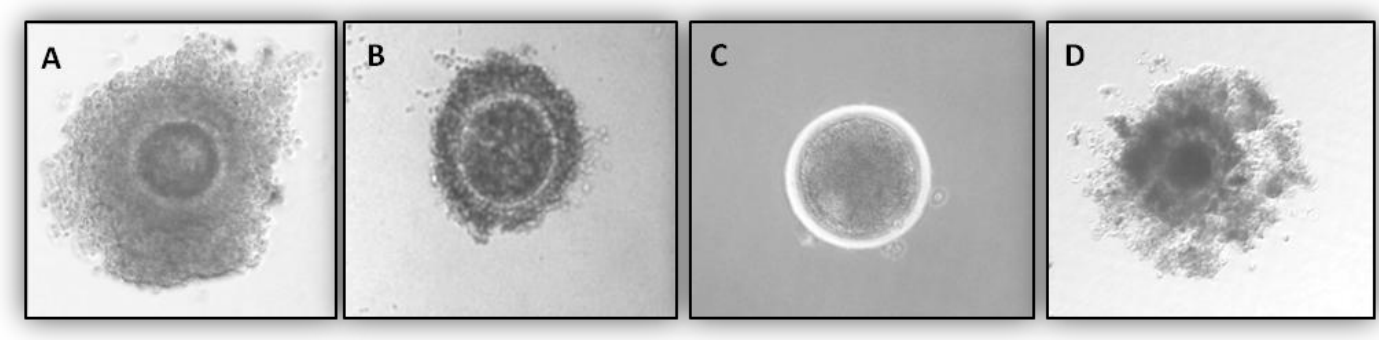

Fig. 1.2. Clasificación de ovocitos bovinos recuperados de ovarios antes del proceso de maduración in vitro. A: ovocito con más de tres capas de células del cumulus, B: ovocito con una a tres capas de células del cumulus, C: ovocito sin células del cumulus, D: ovocito con células del cumulus expandidas. 
Las células del cumulus y el ovocito mantienen un intercambio metabólico intenso mediado por factores paracrinos y a través de uniones gap. En los COCs aislados de folículos antrales tempranos, la comunicación por medio de uniones gap funcionales promueve el crecimiento del ovocito, el silenciamiento gradual del transcriptoma, la remodelación de la cromatina y la adquisición de competencia; todas controladas mediante el adenosín monofosfato cíclico (cAMP, del inglés cyclic adenosine monophosphate) del ovocito (Luciano y cols., 2011, 2018).

La maduración nuclear y citoplasmática de los ovocitos es determinante para la fecundación y el desarrollo embrionario posterior. La maduración nuclear implica la reanudación de la división meiótica hasta metafase II y la extrusión del primer corpúsculo polar, mientras que la maduración citoplásmica incluye la redistribución de orgánulos (Ferreira y cols., 2009) y la acumulación de ARNm, proteínas, sustratos y nutrientes (Watson, 2007).

Se ha demostrado que factores como el origen de los ovocitos (OPU o matadero) y el tamaño de los folículos, así como la edad, la raza y la salud de las donantes influyen en la competencia in vitro de los ovocitos bovinos (Gilchrist y cols., 2004; Luciano y Sirard, 2018). La competencia en el desarrollo de los ovocitos, a corto plazo, se define generalmente como la capacidad del gameto femenino para madurar, ser fertilizado y mantener el desarrollo del embrión hasta el estadío de blastocisto (Conti y Franciosi, 2018) y durante la elongación (Nuttinck y cols., 2017). Sin embargo, a largo plazo, la competencia de los ovocitos se relaciona con la capacidad de producir gestaciones a término y generar una descendencia sana (Sirard y cols., 2006; Lonergan y cols., 2016; Nuttinck y cols., 2017). La reducción en los porcentajes 
de producción de blastocistos se puede atribuir en parte a la heterogeneidad de la población de ovocitos que normalmente se recupera para maduración in vitro, ya que frecuentemente no provienen de folículos preovulatorios (Wrenzycki, 2016). Los ovocitos completan la fase de MIV al cabo de 22 a 24 h; entonces se puede iniciar el proceso de fecundación. En bovinos, aproximadamente el $90 \%$ de los ovocitos inmaduros de buena calidad maduran in vitro con éxito (Mermillod y cols., 2006).

\subsubsection{Fecundación in vitro}

La FIV implica la unión de los gametos femeninos y masculinos durante un período de coincubación. El semen bovino congelado tiene que ser descongelado y tratado adecuadamente antes de la FIV. Los métodos de separación se usan para eliminar el diluyente espermático y los espermatozoides muertos, consiguiendo así espermatozoides vivos y móviles. Comúnmente, se usan dos métodos para la separación de espermatozoides: el método "swim-up" basado en las características de motilidad espermática (Parrish y cols., 1986) y el método de gradiente discontinuo basado en las diferentes densidades de los espermatozoides vivos y muertos (Saeki y cols., 1991).

Los medios y protocolos comúnmente utilizados para la FIV en bovino descritos por Parrish y cols., (1986) no han sufrido en general modificaciones considerables. Los espermatozoides necesitan ser capacitados para fertilizar ovocitos durante la FIV. La capacitación de los espermatozoides supone la modificación de la membrana espermática y cambios en la motilidad del 
gameto. La capacitación espermática se induce con la suplementación de agentes de capacitación a los medios de fecundación dependiendo de las características espermáticas de cada toro. Uno de los agentes de capacitación usado comúnmente es la heparina. La heparina se une a las proteínas del plasma seminal (BSP, del inglés bovine seminal plasma proteins) y las elimina de la membrana plasmática junto con el colesterol y los fosfolípidos asociados. La heparina reduce la capacidad de los espermatozoides para expulsar $\mathrm{Ca}^{2+}$ a través de la calcio-ATPasa. También se produce una absorción de $\mathrm{Ca}^{2+}$ extracelular en el acrosoma, lo que da lugar a un incremento del calcio intracelular, a la vez que se induce la salida de $\mathrm{H}^{+}$y entrada de $\mathrm{HCO}_{3}$. Los cambios de $\mathrm{HCO}_{3}{ }^{-}$y H$^{+}$aumentan el $\mathrm{pH}$ intracelular $\left(\mathrm{pH}_{\mathrm{i}}\right)$ y tanto el $\mathrm{HCO}_{3}{ }^{-}$como el incremento del $\mathrm{pH}_{\mathrm{i}}$ estimulan la adenil ciclasa soluble (sAC, del inglés soluble adenylate cyclase) de los espermatozoides. El cAMP resultante activa la proteína quinasa $\mathrm{A}$ (PKA, del inglés protein kinase $A$ ), la cual mediante comunicación cruzada estimula a su vez las tirosina quinasas (PTK, del inglés protein tyrosine kinases) e inhibe las tirosina fosfatasas (Ptyr-Ptase, del inglés protein tyrosine phosphatases) produciéndose finalmente, la transferencia de un grupo fosfato desde el ATP a los residuos de tirosina presentes en diversas proteínas. El incremento de calcio intracelular estimula aún más la SAC y la inhibición de Ptyr-Ptase (Fig. 1.3) (Breininger y cols., 2010; Parrish, 2014). Recientemente, se ha descrito un nuevo fenómeno biológico asociado a la capacitación de espermatozoides mamíferos in vitro, el cual implica una redistribución de iones de zinc en el espermatozoide (Kerns y cols., 2018). 


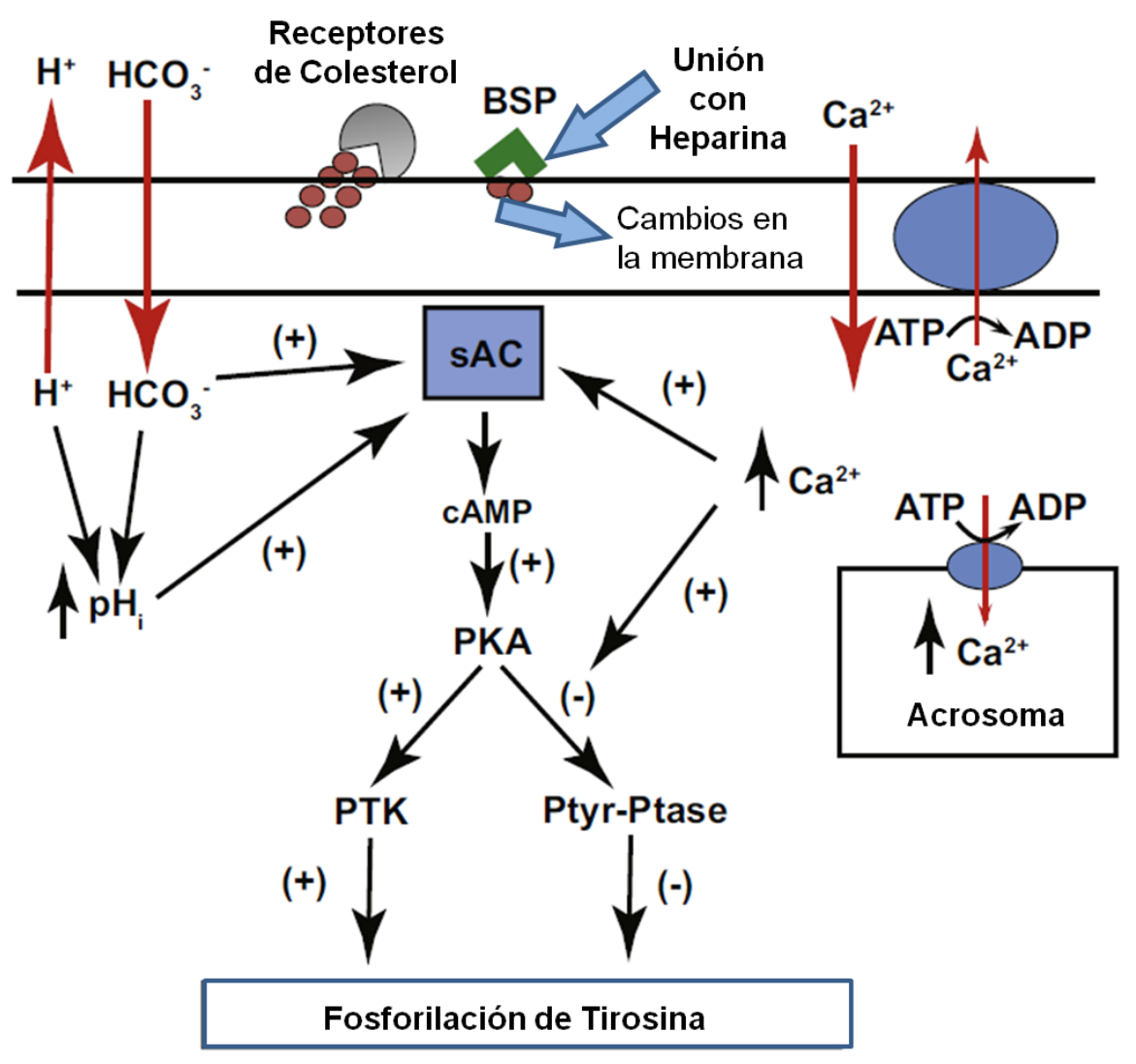

Fig. 1.3. Esquema de los procesos intracelulares inducidos por la heparina durante la capacitación de espermatozoides bovinos. (Adaptado de Parrish, 2014).

Otros agentes, como la penicilamina, hipotaurina y epinefrina (PHE), se usan para mejorar los porcentajes de penetración espermática cuando los espermatozoides son de baja calidad (Susko y Parrish, 1990; Parrish, 2014).

El uso de semen sexado posibilita la producción de embriones in vitro del sexo deseado, de gran interés en las explotaciones bovinas de leche (hembras de reemplazo) y carne (machos para engorde). El semen bovino puede ser sexado a partir de eyaculados frescos (sexaje convencional) y también de dosis previamente congeladas (sexado inverso de semen; Underwood, 2010). El método de separación espermática se basa en las diferencias del contenido de ADN entre el cromosoma $X$ y el cromosoma $Y$, medido por citometría de flujo. Sin embargo, se han descrito porcentajes de blastocistos in vitro más bajas con 
el uso de semen sexado frente a las obtenidas con semen convencional, aunque con un marcado efecto individual de cada toro (Trigal y cols., 2012).

En bovinos, la concentración final de espermatozoides utilizada en la FIV varía entre 0.5 y $2 \times 10^{6}$ espermatozoides por mililitro de medio de fecundación. Esta concentración debe optimizarse para cada toro y a veces para cada eyaculado de un mismo toro. Comúnmente, los ovocitos maduros se incuban con espermatozoides móviles capacitados durante 18-20 h, aunque una coincubación de 6h basta para una fecundación efectiva (Galli, 2003; Gordon y cols., 2003).

En la FIV, los espermatozoides deben atravesar las células del cumulus que rodean al ovocito hasta llegar a la zona pelúcida (ZP). La zona pelúcida es una matriz extracelular gruesa y translúcida que rodea al ovocito y al embrión hasta el momento de la eclosión. En bovinos, la ZP está compuesta por tres glicoproteínas Ilamadas ZPA/ZP2, ZPB/ZP4, ZPC/ZP3 (Goudet y cols., 2008; Avilés y cols., 2010; Suzuki y cols., 2015). El contacto entre el espermatozoide y la ZP induce la reacción acrosómica (exocitosis) del espermatozoide, el cual terminará fusionándose con el ooplasma y activando el ovocito dando inicio a la formación de los pronúcleos (Sutovsky., 2011). Al tiempo, se activa el bloqueo de la polispermia mediante la liberación de moléculas contenidas en los gránulos corticales que producen importantes modificaciones químicas, particularmente en la zona pelúcida, el espacio perivitelino y el oolema del ovocito. Recientemente, la exocitosis de gran cantidad de iones de zinc (zinc spark) emitidos por el ovocito e inducido por los espermatozoides durante la fertilización ha sido propuesto como un nuevo biomarcador de la calidad del embrión y del potencial de desarrollo embrionario en ratones (Que y cols., 
2015; Zhang y cols., 2016). Los porcentajes de fecundación con semen convencional pueden alcanzar promedios de un $80 \%$ o más, mientras que con semen sexado se han reportado porcentajes de fecundación de hasta $60 \%$ (Yang Li y cols., 2018).

\subsubsection{Cultivo in vitro}

El CIV de embriones bovinos comprende el desarrollo desde el estadío de zigoto hasta los diferentes estadíos de blastocisto. En su fase inicial, el desarrollo embrionario temprano está regulado por transcritos de ARN maternos y por proteínas producidas y almacenadas durante la ovogénesis (Graf y cols., 2014). Las divisiones mitóticas transforman el zigoto en un embrión multicelular a través de un proceso llamado segmentación. Cada célula generada se denomina blastómero y su tamaño disminuye conforme avanza la división celular, sin afectar el tamaño del embrión hasta el estadío de blastocisto.

En los mamíferos, la división celular después del estadío de dos células suele ser asincrónica, generando embriones con un número irregular de blastómeros (Prados, 2012). Al comienzo del desarrollo embrionario los blastómeros son totipotentes, lo que significa que pueden ser inducidos a convertirse en cualquier tipo de célula fetal o adulta. Las proteínas y los transcritos maternos se degradan gradualmente mientras los transcritos del embrión comienzan a sintetizarse una vez que se produce la transición materno-embrionaria (TEM). La TEM incluye la activación del genoma embrionario (AGE; Graf y cols., 2014). En bovino, la AGE se produce entre los estadios de 8 a 16 células 
(Cagnone y Sirard, 2013), aunque la heterogeneidad del transcriptoma en células individuales de embriones bovinos de día dos y tres de cultivo después de la fecundación, sugiere un desarrollo asincrónico de los blastómeros durante la fase de mayor AGE (Lavagi y cols., 2018).

Con el avance de las divisiones celulares, los blastómeros periféricos se aplanan y se inicia una síntesis de proteínas específicas que favorecen uniones intercelulares más estrechas, lo cual genera un mayor contacto entre las células embrionarias. El embrión pasa a llamarse mórula y la compactación celular se hace más evidente a medida que avanza el desarrollo embrionario. La transcripción del genoma embrionario después del TEM es extremadamente dinámica y controla la compactación de la mórula y el posterior desarrollo del blastocisto (Rodríguez-Zas y cols., 2008).

El estadío de mórula se caracteriza por la formación de uniones membranosas estrechas y oclusivas (uniones tight) (Gualtieri y cols., 1992; Boni y cols., 1999) entre los blastómeros periféricos, mientras que entre los blastómeros internos se forman estrechas uniones de membrana que propician la comunicación intercelular (uniones gap) (Wrenzycki y cols., 1996; Boni y cols., 1999). La adquisición de uniones gap durante la compactación proporciona una mejor coordinación entre las células embrionarias en términos de metabolismo, transmisión de señal y respuesta a las condiciones externas (Cagnone y Sirard, 2016). Una vez que el embrión está completamente compactado se forma gradualmente una cavidad llena de líquido (blastocele) que aumenta conforme avanza el desarrollo embrionario. En esta fase el embrión pasa a denominarse blastocisto. 
El blastocisto está formado por células que forman una capa externa o trofectodermo (TF), una masa celular interna $(\mathrm{MCl})$ y el blastocele. El blastocele se forma progresivamente en respuesta a la alta concentración de cationes generada por la actividad de la bomba $\mathrm{Na}+/ \mathrm{K}+$ en las células del TF. Las células del TF formarán la parte fetal de la placenta y las membranas embrionarias adicionales. Las células de la $\mathrm{MCl}$ son pluripotentes y producirán todos los tejidos embrionarios y una parte de las membranas extra embrionarias (Wang y Dey, 2006). A medida que el blastocele se expande, la zona pelúcida se hace cada vez más fina y el tamaño del embrión se incrementa (Fig. 1.4).

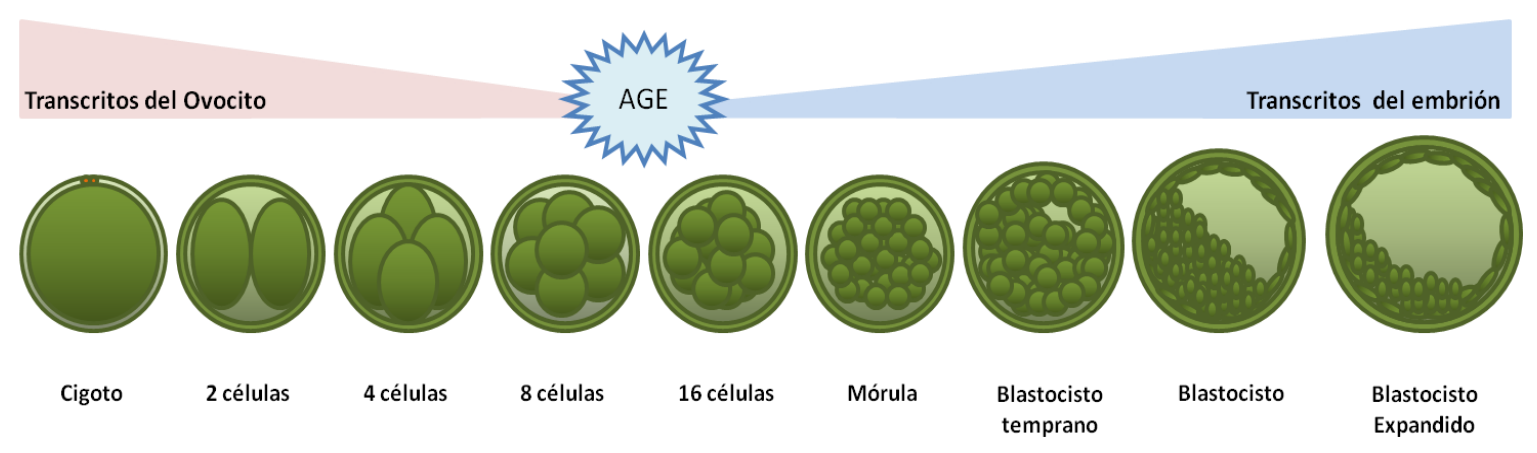

Fig. 1.4. Desarrollo embrionario bovino. AGE: activación del genoma embrionario.

En la producción de embriones bovinos in vitro, el blastocisto expandido (XB) es el estadío más resistente a la criopreservación, produciendo mejores índices de gestación en comparación con otros estadíos embrionarios anteriores o posteriores (Kubisch y cols., 2004; Randi y cols., 2016). Tras una notable expansión, el embrión in vitro se libera de la adelgazada zona pelúcida mediante ciclos alternativos de contracción y expansión, en un proceso que se denomina eclosión. No está claro si en el desarrollo in vitro proteasas del TF pueden contribuir a degradar la ZP, tal como parece ocurrir en el útero in vivo. 


\subsubsection{Características de los medios de cultivo in vitro para bovinos}

Se han diseñado diferentes sistemas de CIV con el objetivo de imitar en la medida de lo posible las condiciones fisiológicas in vivo de los embriones bovinos. Por lo general, los medios de cultivo utilizados para PIV de embriones bovinos son una mezcla de componentes que pueden incluir: agua, sales, fuentes de energía, macromoléculas, aminoácidos, sustancias tampón y antioxidantes.

La osmolaridad y $\mathrm{pH}$ del medio CIV son factores importantes para el desarrollo de embriones de mamíferos. En el tracto reproductivo de la vaca, el fluido oviductal y uterino presentan osmolaridades alrededor de 290 y 315 mOsM respectivamente (Menezo y Guerin, 1997; Baltz, 2001) y se ha señalado que los embriones bovinos soportan osmolaridades de entre 250 y 300 mOsM en los medios de CIV (Baltz, 2001; Gasperin y cols., 2016). El fluido oviductal y uterino muestran valores de $\mathrm{pH}$ de 7.6 y 6.9 respectivamente (Hugentobler $y$ cols., 2004), mientras que la mayoría de los medios para producción de embriones bovinos in vitro tienen un $\mathrm{pH}$ de 7.3 a 7.4 , excepto en los medios de fecundación, que generalmente oscila entre 7.5 y 7.6 (Hasler y Barfield, 2014).

Diferentes tipos de aceite mineral o siliconas son un componente importante en varios sistemas de cultivo de gametos y embriones de mamíferos. Por lo general, se puede usar aceite mineral para recubrir los medios y evitar la evaporación, estabilizar el $\mathrm{pH}$ y la temperatura y evitar cambios de osmolaridad. Los aceites para la producción de embriones in vitro están constituidos a base de silicio o carbono (ambos de origen mineral) y pueden volverse tóxicos para los embriones en cualquier momento (Martínez y cols., 
2017). La exposición a la luz durante la producción de embriones bovinos in vitro debe limitarse a mínimos (Vatja, 2010).

El medio base más utilizado en el CIV de embriones bovinos es el medio sintético de fluido de oviducto (SOF) descrito por Tervit y cols., (1972). Frecuentemente, el medio SOF se ha suplementado con aminoácidos esenciales y no esenciales, citrato, mioinositol (SOFaaci, Holm y cols., 1999) y fuentes de proteína como suero o BSA. El suero tiene un efecto bifásico sobre el desarrollo embrionario, inhibiendo los primeros estadios y estimulando el desarrollo de mórulas y blastocistos (Pinyopummintr y Bavister 1994, Thompson y col 1998, Gómez y Diez 2000, Holm y col 2002). Sin embargo, se ha demostrado que el suero puede ser perjudicial para el desarrollo in vitro de embriones, ya que disminuye drásticamente la calidad embrionaria (Heras $y$ cols., 2016). Así, la presencia de suero en el cultivo embrionario modifica los orgánulos celulares, degrada las mitocondrias, altera la expresión génica, aumenta el contenido de lípidos y reduce la supervivencia a la criopreservación (Abe y cols., 2002; Rizos y cols., 2003; Gómez y cols., 2008; Sudano y cols., 2011). Además, una vez que los embriones son transferidos a receptoras los riesgos de alteraciones fetales, distocias y problemas perinatales se incrementan con el uso de suero durante el CIV (Farin y cols., 2001; Lazzari y cols., 2002).

La BSA es la proteína más abundante en el tracto reproductivo femenino y ha sido usada frecuentemente en los CIV como reemplazante del suero (Leese, 1988). No obstante, la composición de los tipos y lotes de BSA no es homogénea. La BSA es un compuesto de proteína no definido ya que contiene lípidos, aminoácidos, hormonas, péptidos, metales y otras moléculas no 
conocidas de bajo peso molecular que determinan una variación significativa entre lotes (O'Neill, 2008; Francis, 2010). Estas variaciones afectan directamente al desarrollo y calidad de los embriones in vitro (Rorie y cols., 1994; Francis, 2010). La BSA actúa limitando los efectos de toxinas y regulando el potencial óxido-reductor, el $\mathrm{pH}$ y la osmolaridad en los medios de cultivo (Gardner, 2008). No obstante, El uso de medios químicamente definidos tiene ventajas, como son la mayor repetibilidad de los ensayos (entre y dentro de laboratorios) y la no incorporación de moléculas con actividad biológica desconocida que pueden alterar los resultados de diferentes análisis de los medios de cultivo (Summers y Biggers, 2003; Gómez y cols., 2016).

Uno de los reemplazantes macromoleculares sintéticos más utilizados en los medios de CIV de embriones mamíferos es el alcohol de polivinilo (PVA; Bavister, 1981). EI PVA se ha usado como agente surfactante en medios de lavado y mantenimiento de embriones que están formulados para no incluir componentes de origen animal. Varios estudios realizados en bovino han utilizado el PVA como única macromolécula durante el CIV (Duque y cols., 2003; Orsi y Leese, 2004) y se han obtenido preñeces y terneros saludables (Holm y cols., 1999; Hidalgo y cols., 2005; Lim y cols., 2007). No obstante, la falta de proteína durante todo el periodo de CIV es perjudicial para el desarrollo embrionario ya que se obtienen menores porcentajes de blastocistos (Krisher y Bavister, 1999; Orsi y Leese, 2004).

Los embriones de mamíferos secretan factores tróficos al medio de cultivo, por lo que tienden a crecer mejor cuando se cultivan en grupo que individualmente (Gardner y cols., 1994). La capacidad para el desarrollo embrionario, la calidad del embrión y la sensibilidad a la criopreservación también se ven afectadas 
por el cultivo individual prolongado, y pocos autores describen porcentajes de desarrollo hasta blastocisto similares o superiores a los cultivos en grupo (Goovaerts y cols., 2010). En los programas de OPU para producir embriones bovinos in vitro frecuentemente se requieren sistemas de cultivo para grupos reducidos de embriones. Además, el cultivo individual de embriones es imprescindible para realizar análisis moleculares no invasivos (Bunel y cols., 2015; Gómez y cols., 2016; Parker y cols., 2017). Por lo tanto, es común ajustar el volumen de medio al número de embriones mediante el cultivo en microgotas. El volumen de las microgotas suele variar entre 10 a $50 \mu \mathrm{L}$ y por lo general un volumen menor a $10 \mu \mathrm{L}$ por embrión compromete seriamente el desarrollo de blastocistos en cultivos individuales completos sin renovación de medio (Lane y Gardner, 1992; Carolan y cols., 1996). Aunque los embriones de mamíferos pueden ser cultivados individualmente en microgotas de $2 \mu \mathrm{L}$ es necesaria la renovación del medio de cultivo cada 48h (Kelley y Gardner, 2017).

Para superar los efectos negativos de un cultivo individual completo, se ha descrito un cultivo individual más corto, de tan solo 24 h a partir de embriones seleccionados en día 6 (Muñoz y cols., 2014a). De esta manera, el cultivo individual no afecta a la producción de blastocistos comparado con un cultivo realizado enteramente en grupo y además facilita la aplicación de análisis no invasivos en los medios de cultivo, los cuales pueden usarse para predecir índices de gestación (Muñoz y cols., 2014a, 2014b) y diagnosticar el sexo del embrión (Muñoz y cols., 2014c). 


\subsubsection{Factores de crecimiento para el cultivo in vitro de embriones bovinos}

En el ambiente materno en que se desarrolla el embrión bovino in vivo figuran diversos factores de crecimiento (GFs, del inglés Growth factors), citoquinas, hormonas y otras moléculas reguladoras (Spencer y Bazer, 2004; Muñoz y cols., 2012) que tienen funciones determinantes en el desarrollo embrionario y que pueden variar en función del sexo del embrión (Gómez y cols., 2013). Los GFs pueden ser producidos por el embrión y/o el tracto reproductivo e influyen en el desarrollo embrionario de una manera autocrina o paracrina. La suplementación del CIV con sustancias sintéticas como GFs maternos recombinantes es una alternativa para la optimización de medios de cultivo especialmente cuando se pretende cultivar embriones en condiciones definidas.

En bovino, estudios previos han identificado un gran número de GFs producidos por el oviducto y el útero (Block y cols., 2011; Muñoz y cols., 2017). Además, la suplementación del medio CIV con GFs producidas por el endometrio de la vaca mejora el desarrollo del embrión in vitro y la supervivencia embrionaria después de la transferencia a receptoras (Larson y cols., 1992; Sirisathien y cols., 2003; Neira y cols., 2010; Block y cols., 2011; Fields y cols., 2011; Sakagami y cols., 2012; Gómez y cols., 2014; Moreno y cols., 2015; Muñoz y cols., 2017).

Es importante tener en cuenta que la acción de los GFs en el CIV puede ser dependiente del estadío del embrión, por ejemplo, la suplementación de activina $\mathrm{A}$ en el CIV de embriones bovinos mejora el desarrollo de blastocistos solo a partir del estadío de mórula en día 5, y no antes. Sin embargo, el número 
de células del TE disminuye con la activina A tanto antes como después del estadío de mórula de día 5 , lo que sugiere que la activina $A$ inhibe la diferenciación de TE (Trigal y cols., 2011).

De igual manera, Gómez y cols., (2014) demostraron que el HDGF (del inglés, hepatoma-derived growth factor) está presente en el fluido uterino de vacas en los primeros días de gestación y es sintetizado tanto por el endometrio como por el embrión, pudiendo actuar de forma autocrina y/o paracrina promoviendo el desarrollo temprano de embriones in vitro. Los efectos embriotróficos de los GFs pueden variar dependiendo del estadío embrionario. Así, la presencia de HDGF recombinante (rHDGF) disminuyó el desarrollo embrionario in vitro cuando se agregó en el Día 5 de cultivo, pero aumentó el desarrollo cuando se agregó en el Día 6 (Gómez y cols., 2014).

\subsubsection{Cocultivo de células endometriales y embriones}

El endometrio bovino constituye la capa más interna de la mucosa del útero. Está compuesto por áreas carunculares e intercarunculares que a su vez están formadas mayoritariamente por tres tipos de células: 1) células luminales epiteliales, 2) células glandulares epiteliales (ausentes en el área caruncular) y 3) células del estroma (Gray y cols., 2001), además de vasos sanguíneos y linfocitos. En la vaca, el endometrio sufre cambios estructurales durante el ciclo estral en respuesta a las hormonas circulantes y es responsable de la secreción de numerosas citoquinas, factores de crecimiento y proteínas, las cuales son secretadas desde el epitelio glandular hacia la luz uterina (Ulbrich $y$ cols., 2013). Por lo tanto, es necesario contar con un mejor conocimiento del 
funcionamiento del tracto genital para mejorar las condiciones del cultivo de embriones in vitro.

El cultivo in vitro de células endometriales se ha desarrollado tratando de mantener características estructurales y morfológicas típicas del órgano in vivo (Ulbrich y cols., 2011). Además, el desarrollo de técnicas de cocultivo de células endometriales bovinas y embriones in vitro ha permitido abordar el estudio de las interacciones materno-embrionarias durante las primeras etapas del desarrollo embrionario, estudio cuya realización no es posible o es difícil en el animal vivo. Así, el reducido tamaño del embrión durante las primeras etapas del desarrollo en el útero (mórula-blastocisto) hace que el endometrio adyacente al embrión sea difícil de identificar y aislar, complicando el estudio del microambiente uterino que envuelve al embrión in vivo (Hunter 1994). Los inconvenientes pueden ser más pronunciados con los movimientos del embrión (Muñoz y cols., 2012) y la alta densidad en el fluido uterino (Gómez y cols., 2013).

En bovino, se ha propuesto la transferencia múltiple de embriones (Gómez y Muñoz, 2015) como alternativa capaz de detectar moléculas y efectos en el fluido uterino que no serían cuantificables con la presencia de un solo embrión. Por otro lado, Binelli y cols., (2017) evaluaron el transcriptoma en diferentes secciones y cortes del endometrio bovino en presencia de un embrión de día 7 producido in vivo y encontraron que el patrón de expresión de genes específicos en el endometrio bovino responde a una programación tanto dependiente como independiente del embrión. La programación del endometrio dependiente del embrión requiere proximidad física endometrio-embrión. Por lo 
tanto, el espacio donde tiene lugar la interacción endometrio-embrión es reducido y difícil de aislar para su estudio.

En este sentido, es importante destacar que el cultivo de células endometriales in vitro es un modelo alternativo que contribuye al estudio fisiológico o patológico del endometrio bovino (Asselin y cols., 1996; Cronin y cols., 2012) y que además favorece el análisis de las interacciones materno-embrionarias realizado en presencia de un solo embrión (Gómez y cols., 2018).

\subsection{Criopreservación de embriones producidos in vitro}

La criopreservación de embriones bovinos producidos in vitro se realiza rutinariamente tanto en laboratorios de investigación como en laboratorios comerciales. La criopreservación es un proceso que consiste en someter a los embriones a temperaturas muy bajas, lo que ayuda a reducir la actividad fisiológica de cada célula embrionaria para conservarlos vivos durante largos periodos de tiempo.

En bovinos, la criopreservación de embriones contribuye a reducir los costes en las ganaderías, evita la dependencia de la actividad reproductiva cíclica y del estado fisiológico de los animales y es una necesidad cuando existen excedentes de embriones o escasez de receptoras. De igual manera, la criopreservación facilita la gestión y el uso de embriones para limitar la deriva genética (cambio en las frecuencias alélicas de una población), facilita la creación de bancos de recursos genéticos de razas en peligro de extinción, promueve la comercialización de embriones entre países y elimina las patologías asociadas al mantenimiento de animales vivos. 
En la actualidad, hay dos métodos de criopreservación disponibles para embriones: la congelación lenta o convencional y la vitrificación. Las principales diferencias entre estos dos métodos son la concentración de los crioprotectores y las velocidades de enfriamiento (Vajta y Kuwayama, 2006). Sin embargo, tanto la congelación lenta como la vitrificación pueden afectar de diferente manera la fisiología y la supervivencia del embrión (Fig. 1.5). A pesar de los avances en las técnicas de criopreservación, los resultados continúan siendo distintos entre embriones bovinos producidos in vitro y embriones in vivo. Los medios utilizados en el CIV, la calidad del embrión y el estadío embrionario influyen directamente en la supervivencia de los embriones a la criopreservación. Por lo tanto, las investigaciones para mejorar los métodos de criopreservación en embriones bovinos producidos in vitro continúan.

\subsubsection{Congelación lenta}

En la congelación lenta, los embriones alcanzan un equilibrio osmótico en un medio con crioprotectores en bajas concentraciones. En general, el procedimiento de congelación lenta para embriones bovinos implica enfriar y estabilizar el embrión entre -5.5 y $-7^{\circ} \mathrm{C}$, inducir la cristalización (seeding) y disminuir la temperatura hasta temperaturas próximas a $-32{ }^{\circ} \mathrm{C}$ a una velocidad de $0.3-0.6{ }^{\circ} \mathrm{C}$ por minuto para posteriormente almacenarlos en nitrógeno líquido a $-196{ }^{\circ} \mathrm{C}$ (Hasler, 2007; Almiñana y Cuello, 2015).

Una de las mayores ventajas de la congelación lenta en comparación con la

vitrificación es que simplifica la transferencia directa (TD) de embriones a receptoras, siendo el método de criopreservación predilecto para embriones 
bovinos in vivo (Hasler y cols., 1995; Viana y cols., 2017). Por lo general se tiende a asumir que los embriones bovinos producidos in vitro son más sensibles a la congelación lenta y producen menores indices de gestación en comparación a la técnica de vitrificación. Sin embargo, por los mejores índices de gestación que se obtienen, más del $70 \%$ de los embriones bovinos producidos in vitro a escala mundial han sido transferidos en fresco (Perry, 2016). Aunque, recientemente, se han desarrollado sistemas eficientes de congelación lenta y TD para embriones bovinos producidos in vitro (Sanches y cols., 2016), que son usados principalmente por empresas comerciales.

El proceso de congelación lenta se requiere un equipo relativamente costoso para controlar las curvas de enfriamiento, pero permite una gestión más rápida cuando se dispone de un número elevado de embriones. Además, la congelación lenta posibilita la TD simple de realizar en campo, satisface las exigencias sanitarias y facilita ampliamente la comercialización mundial de embriones.

\subsubsection{Vitrificación}

La vitrificación implica la solidificación de una solución de base acuosa para alcanzar un estado vítreo, amorfo, carente de cristales de hielo. Durante el proceso de vitrificación, el embrión se expone primero a una solución de crioprotectores menos concentrada (1-1.5 mol L-1 $)$, después a una solución de crioprotectores más concentrada $\left(4-8 \mathrm{~mol} \mathrm{~L}^{-1}\right)$ y luego se enfría a velocidad ultra-rápida $\left(\approx-20.000{ }^{\circ} \mathrm{C}\right.$ por minuto o superior), por lo general usando 
nitrógeno líquido $\left(-196^{\circ} \mathrm{C}\right)$. Existen diferentes dispositivos para manejar y alojar el embrión durante la vitrificación (Rall y Fahy, 1985; Arav, 2014).

Desde su desarrollo (Rall y Fahy, 1985), la vitrificación se ha convertido en el método de criopreservación más utilizado para embriones bovinos PIV. La vitrificación es un procedimiento simple, no requiere equipos costosos, es barata (Marco-Jiménez y cols., 2016) y cuando el número de embriones es reducido se puede realizar en poco tiempo. Sin embargo, algunos protocolos de vitrificación producen toxicidad por la exposición a altas concentraciones de crioprotectores y un mayor daño causado por el choque osmótico. Para tratar de disminuir la toxicidad específica de cada crioprotector, se ha tratado de encontrar crioprotectores menos tóxicos y más permeables, y usar dos o tres crioprotectores añadidos de forma gradual (Saragusty y Arav, 2011; Trigal y cols., 2012; Caamaño y cols., 2015). La desventaja principal del método de vitrificación es que no se ha desarrollado un método eficaz que permita la TD a receptoras y por tanto es necesario contar con personal entrenado para manipular y evaluar los embriones antes de la transferencia, dificultando su aplicación comercial a gran escala. 


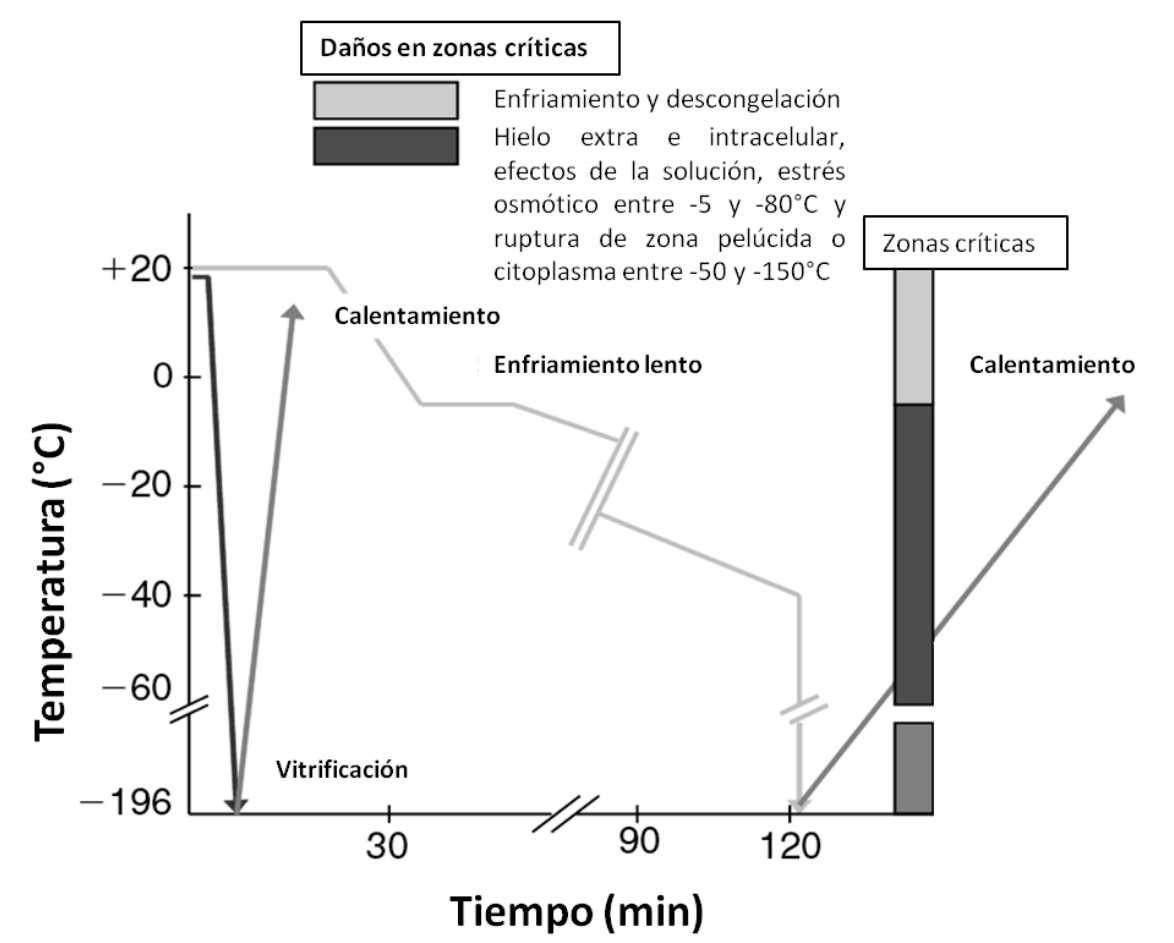

Fig. 1.5. Esquema de enfriamiento y zonas críticas de daño celular durante la criopreservación. Adaptado de Quin, 2010 y Vatja, 2006.

\subsection{Evaluación de la calidad y viabilidad de embriones bovinos producidos in vitro}

En general, la calidad y los porcentajes de desarrollo de embriones bovinos producidos in vitro pueden variar ampliamente. Estas diferencias vienen dadas por la diversidad inherente al potencial de los gametos y por las condiciones de los medios de producción in vitro de embriones. Uno de los objetivos principales de la investigación en embriones bovinos in vitro es desarrollar un método de selección eficaz que permita predecir con precisión la calidad y viabilidad de los embriones. Los métodos que se han utilizado para este objetivo se clasifican como invasivos o no invasivos. Desde el punto de vista práctico, se prefiere métodos no invasivos ya que las técnicas invasivas, por lo general, implican un daño parcial en la estructura (reduce la viabilidad) o la muerte del embrión. 


\subsubsection{Morfología}

La evaluación morfológica de los embriones bovinos se ha estudiado ampliamente, primero en embriones in vivo y posteriormente en embriones in vitro, ambos con el objetivo de seleccionar con precisión los mejores embriones, tanto en fresco como después de criopreservación. Los parámetros de morfología en embriones bovinos in vivo incluyen la forma, el color, el estadío del embrión, el número de células extruidas y degeneradas y el número y tamaño de las vesículas (Linder y Wright 1983; Stringfellow y Givens, 2010); parámetros que también se evalúan en embriones bovinos PIV (Hasler, 1995; Van Soom y cols., 1997).

En la observación mediante estereomicroscopio (Fig. 1.6), los embriones producidos in vitro muestran morfología alterada, diferentes patrones de desarrollo, mayor número de vacuolas y parecen ser más opacos en comparación con los embriones obtenidos in vivo (Iwasaki y cols., 1990; Rizos y cols., 2002). Los blastocistos bovinos producidos in vitro además presentan uniones intercelulares más débiles que los blastocistos in vivo (Prather, 1993). Estas diferencias morfológicas entre embriones in vivo e in vitro también han sido descritas mediante microscopía electrónica (Crosier y cols., 2000; Crosier y cols., 2001).

Las condiciones de CIV también pueden afectar a la morfología del embrión en desarrollo. Por ejemplo, la suplementación del medio de cultivo con suero o diferentes tipos de BSA altera el aspecto de los embriones. Sin embargo, los blastocistos bovinos in vitro producidos sin suero tienen una morfología más parecida a los blastocistos in vivo (Rizos y cols., 2003). Por lo general, el uso 
de suero en el CIV aumenta los niveles de lípidos en el embrión. Los lípidos incorporados del suero pasan a formar parte de las vesículas formadas en los embriones, lo que hace que el embrión adopte una apariencia más oscura y con frecuencia vesicular o punteada (Gardner, 1994). Además, el suero puede contener sustancias que promueven la síntesis de lípidos por el embrión.

Además, es factible que los suplementos de albúmina también puedan alterar la morfología del embrión. Existe una amplia variedad de preparaciones de BSA comerciales, aunque la gran mayoría contiene componentes no conocidos de bajo peso molecular (Francis y cols., 2010), entre los cuales la parte lipídica puede variar. Por lo tanto, diferentes fuentes de albúmina podrían también modificar el aspecto del embrión.

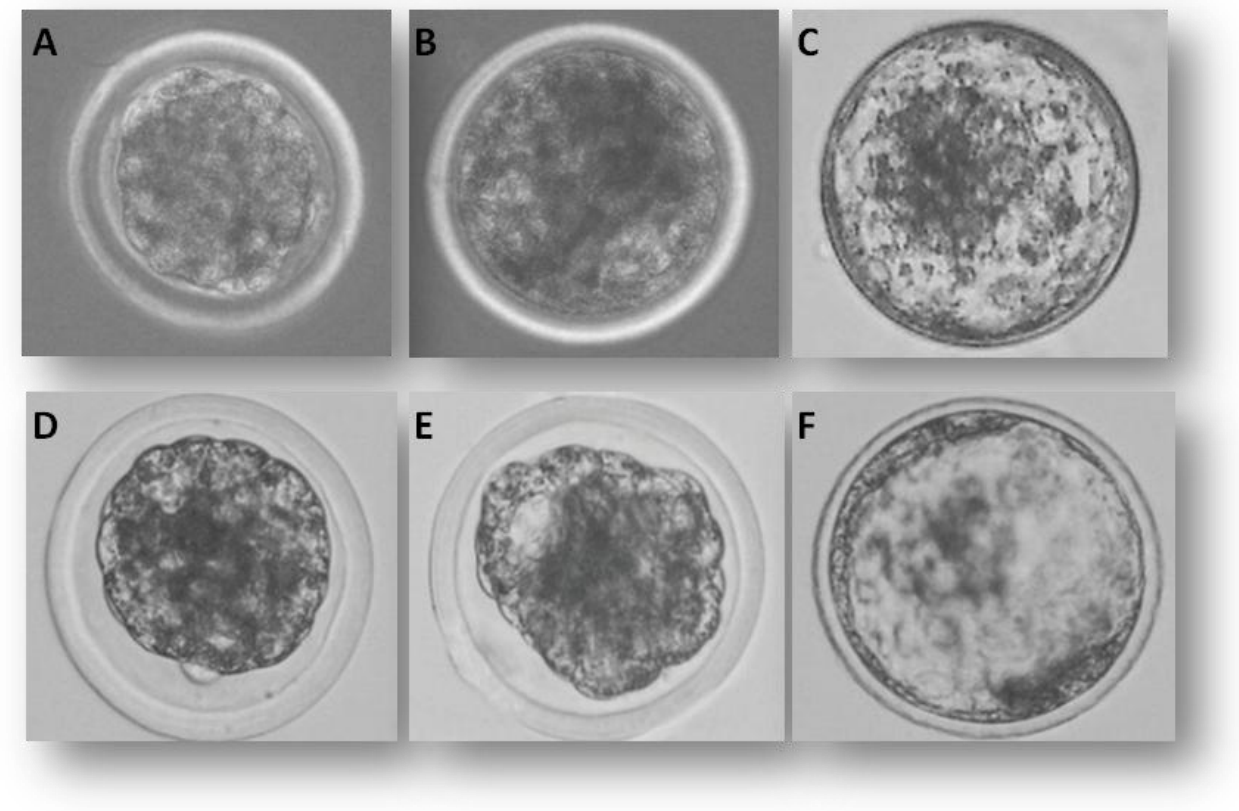

Fig. 1.6. Diferentes estadios de embriones bovinos producidos in vitro $(\mathbf{A}, \mathbf{B}, \mathbf{C})$ e in vivo (D,E,F). A,D: Mórula; B,E: Blastocisto temprano; C,F: Blastocisto expandido. (D,E,F: Adaptado de Jahnke y cols., 2014) 


\subsubsection{Recuento total y diferencial de células embrionarias}

La evaluación del número total de células embrionarias se considera una prueba de calidad embrionaria. Para realizar un recuento celular total generalmente se usan tinciones de ADN que ayudan a visualizar los núcleos celulares. Las tinciones fluorescentes de ADN, Bisbenzimida (Bb) y DAPI, tiñen los núcleos en azul y son las más usadas para evaluar el número total de células embrionarias. La membrana celular es permeable a la Bb y DAPI, por lo que no es necesario permeabilizar el embrión previamente.

Otro colorante fluorescente de ADN usado regularmente es el yoduro de propidio (IP), que tiñe los núcleos celulares en rojo. El IP es impermeable a las membranas celulares, por lo cual el embrión debe ser permeabilizado previamente. Así, Thouas y cols., (2001) desarrollaron una técnica, no inmunohistoquímica (en contraste con Van Soom y cols., 2001), que hace posible el marcaje fluorescente de los dos tipos celulares del embrión. EI IP puede usarse en combinación con $\mathrm{Bb}$ o DAPI para realizar un marcaje diferencial entre las células de la $\mathrm{MCl}$ y del TF. Tras una primera permeabilización en una solución de IP y tritón los embriones se fijan en etanol con $\mathrm{Bb}$. Como resultado se distinguen las células de la $\mathrm{MCl}$, situadas internamente y teñidas de azul, por efecto de la Bb, y las células del TF de color rosa debido a la combinación de IP y Bb.

Una posible asincronía en la división mitótica de los blastómeros podría reflejarse en alteraciones de compactación de la mórula y en la posterior diferenciación de la MCl y del TF (Johnson y Ziomek, 1981). La tinción diferencial se puede utilizar para obtener una mejor estimación de la calidad y 
del grado de diferenciación del embrión. Por lo tanto, esta técnica permite comparar el desarrollo de $\mathrm{MCl}$ y TF en diferentes condiciones de cultivo para evidenciar desviaciones en el desarrollo de embriones (Van Soom y cols., 2001).

El porcentaje de células de la $\mathrm{MCl}$ respecto al número total de células embrionarias se ha considerado indicador de calidad, y esa relación es menor cuando los embriones bovinos son producidos in vitro (Iwasaki y cols., 1990). Los embriones producidos in vitro presentan un número de células totales comparable a los producidos in vivo, aunque, su número de células de la $\mathrm{MCl}$ es significativamente inferior (Van Soom y cols., 2001). La producción de embriones con más células en la $\mathrm{MCl}$ puede mejorar los índices de gestación (Loureiro y cols., 2009); por el contrario, un exceso de células del TF puede conducir a anomalías de la gestación (Van Soom y cols., 1997).

También se han descrito que algunas moléculas como por ejemplo el ácido retinoico (Rodríguez y cols., 2006; 2007), la activina A (Trigal y cols., 2011), el suero (Mucci y cols., 2006), la forskolina (Sudano y cols., 2017) influyen en la diferenciación del blastocisto bovino PIV. Por otro lado, los embriones cultivados en un medio libre de BSA no mostraron cambios significativos en los recuentos celulares ni tampoco índices de gestación más elevados que los embriones cultivados con BSA (Lim y cols., 2007). Sin embargo, aunque se precisa un número mínimo de células en el blastocisto para establecer preñez (Iwasaki y cols., 1990), el número óptimo de células y cómo han de distribuirse entre la $\mathrm{MCl}$ y el TF no están claros. 


\subsubsection{Apoptosis y daño celular}

La apoptosis es un proceso natural que tiene lugar en todos los tipos de células. Su función durante el desarrollo del embrión es eliminar las células anormales, no funcionales o potencialmente peligrosas. La incidencia de apoptosis o muerte celular programada es un parámetro importante para evaluar la calidad embrionaria. Un aumento desmesurado en la proporción de células apoptóticas puede conducir a la muerte del embrión (Levy y cols., 2001; Fabian y cols., 2005). También se ha descrito la necrosis celular, que es un tipo de muerte celular accidental debido a factores externos y que se puede diferenciar de la apoptosis por el aspecto de las células necróticas (Majno y Joris, 1995).

Los métodos más comunes para la detección de apoptosis están basados en técnicas de tinción inmunológicas. La prueba TUNEL (Terminal deoxynucleotidyl transferase dUTP nick end labeling) se basa en el uso de la deoxinucleotidil transferasa terminal, enzima que cataliza la unión de dUTP marcado con fluoresceína, a los extremos 3'-OH libres presentes en el DNA fragmentado como consecuencia de la apoptosis. Se consideran apoptóticos aquellos núcleos que presentan un marcaje positivo y una morfología particular, según criterios descritos por Gjorret y cols., (2003).

La cuantificación de la apoptosis ha recibido especial atención debido a su correlación con la muerte embrionaria temprana, condiciones de desarrollo subóptimas, respuestas celulares al estrés y reducción de la viabilidad embrionaria (Byrne y cols., 1999; Matwee y cols., 2000; Gardner y cols., 2000; Rodríguez y cols., 2006). Además, los índices de apoptosis en células 
embrionarias muestran alta correlación con la supervivencia a la criopreservación de embriones bovinos producidos in vitro (Sudano y cols., 2012).

\subsubsection{Contenido de lípidos intracelulares}

Los lípidos son moléculas hidrofóbicas que desempeñan papeles fundamentales en el metabolismo embrionario de los mamíferos. Son fuente de energía, mediadores de señalización celular y base estructural de las membranas plasmáticas (McKeegan y Sturmey, 2011). El contenido de lípidos en las células embrionarias se organiza en gotas de diferentes tamaños. Cada gota lipídica contiene un núcleo de lípidos esterificados, como son pueden ser los triacilglicéridos, los esteres de colesterol, los esteres de retinol y también ácidos grasos libres (Fig.1.7). Cada gota está recubierta por una monocapa de fosfolípidos y proteínas específicas entre las que destacan la familia de las perilipinas (Guo y cols., 2009) (Fig.1.6). La tinción fluorescente Nile Red (NR) se usa frecuentemente para visualizar gotas de lípidos intracelulares en ovocitos y embriones de mamíferos (Genicot y cols., 2005; Leroy y cols., 2005). En un ambiente hidrofóbico, el NR emite una fluorescencia que va de amarillo a naranja. Los lípidos neutros como los triglicéridos (gotas de lípidos) son fluorescentes en amarillo, mientras que los lípidos polares (fosfolípidos) son fluorescentes en el espectro naranja. La fluorescencia emitida por el NR es específica para las gotas de lípidos y no para el citosol o el compartimento nuclear, debido a que las gotas de lípidos contienen principalmente triglicéridos (Genicot y cols., 2005). 

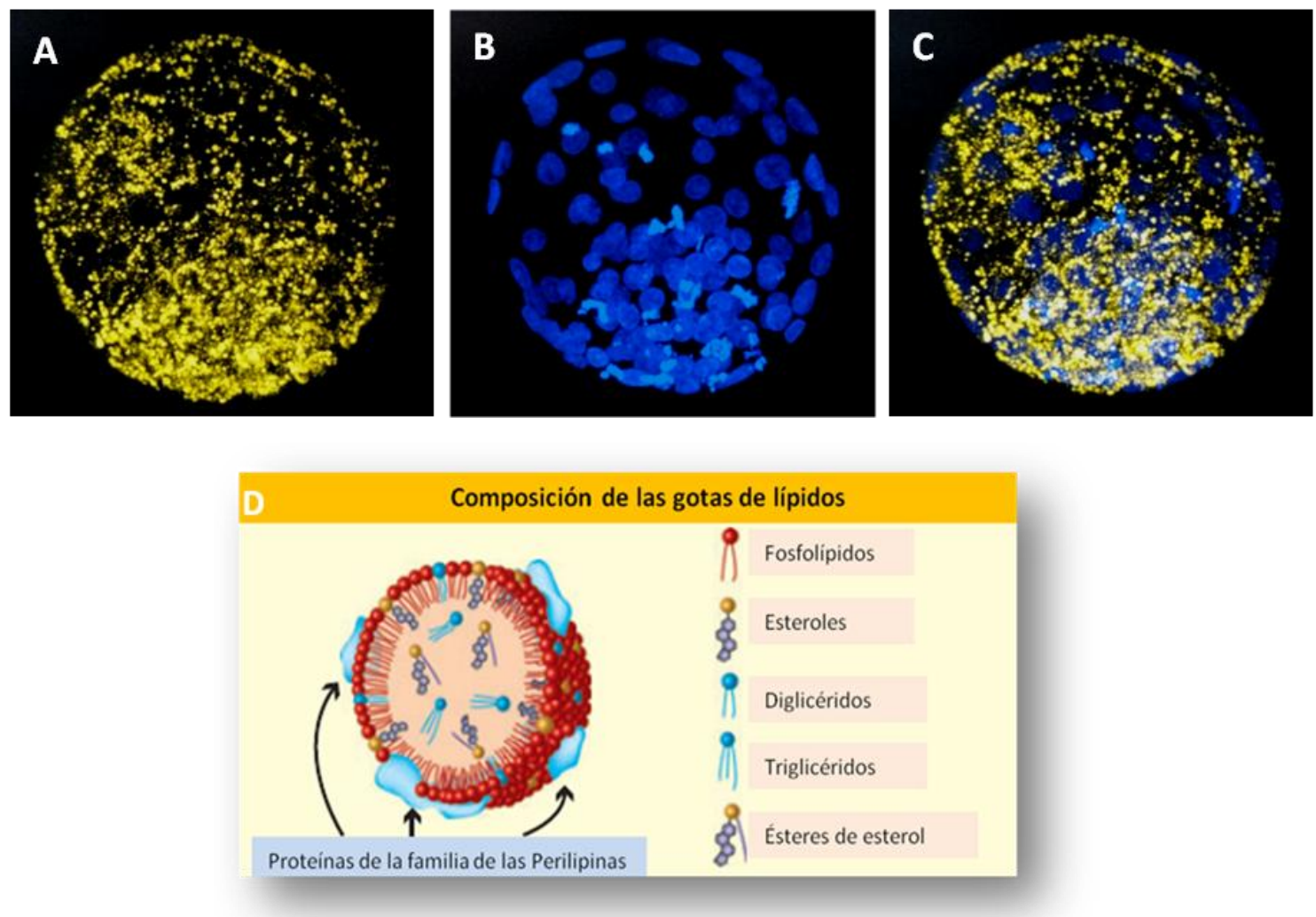

Fig. 1.7. Acumulación de lípidos intracelulares en un blastocisto expandido bovino producido in vitro. A: gotas de lípidos intracelulares teñidas con Nile Red. B: núcleos celulares teñidos con DAPI. C: imagen conjunta de gotas de lípidos intracelulares y núcleos celulares D: Representación esquemática de la composición de las gotas de lípidos (Adaptado de Guo y cols., 2009).

Durante periodos de deficiencia energética, la célula accede a los depósitos lipídicos y recupera la energía almacenada mediante la actividad de hidrolasas especificas, conocidas como lipasas (Ducharme y Bickel, 2008). Los lípidos usan principalmente la ruta de la $\beta$-oxidación mitocondrial para generar ATP durante la maduración de los ovocitos y el desarrollo embrionario temprano (Sturmey y Leese, 2003; Dunning y cols., 2010), aunque también pueden usar el peroxisoma (oxidasas, catalasas).

El exceso de lípidos intracelulares aumenta la sensibilidad del embrión al estrés oxidativo y reduce la supervivencia a la criopreservación de embriones bovinos producidos in vitro (Abe y cols., 2002, Reis y cols., 2003, Sudano y cols., 2011). 
Se ha descrito que la acumulación de lípidos puede verse influenciada por el uso de ciertos suplementos (por ejemplo suero, BSA) durante el CIV o como resultado de alteraciones en el metabolismo de la energía, resultando también afectadas las propiedades y la estabilidad de las membranas celulares (Dinnyes y Nedambale, 2009).

\subsubsection{Prueba de supervivencia a la criopreservación}

Los procesos de criopreservación son una fuente de estrés para los embriones bovinos (Puscheck y cols., 2015) por lo que la supervivencia a estos procesos puede ser usada como indicador de la calidad embrionaria. En la prueba de supervivencia a la criopreservación in vitro se evalúan los porcentajes de reexpansión y de eclosión de los embriones después de un período de CIV (Dinnyés y cols., 1999). Varios sistemas de cultivo se han utilizado para este fin y la mayoría bajo condiciones no definidas (Massip y cols., 1993; Rizos y cols., 2001).

El estadío de desarrollo y la morfología son los parámetros habitualmente usados para seleccionar los embriones in vitro que van a ser criopreservados. Esto es así en la práctica, a pesar que la estimación de la supervivencia a la criopreservación sigue siendo incierta y subjetiva (Sudano y cols., 2012). La supervivencia a la criopreservación puede verse afectada por el sistema de cultivo utilizado antes y después de la criopreservación en los embriones bovinos PIV (Kaidi y cols., 1998; Rizos y cols., 2001). Además, la intensidad del daño causado por la criopreservación a la célula embrionaria depende del 
tamaño y forma de éstas, así como de la permeabilidad de la membrana y la calidad de los embriones (Vatja y cols., 2006).

La presencia de suero durante el CIV es la principal causa del aumento en el contenido lipídico de embriones bovinos in vitro (Abe y cols., 2002), lo que incide en su baja supervivencia a la criopreservación (Mucci y cols., 2002; Rizos y cols., 2003). En consecuencia, se han estudiado varias estrategias para tratar de reducir el contenido de lípidos en los embriones.

Sudano y cols., (2011) demostraron que una concentración reducida de suero $(2.5 \% \mathrm{v} / \mathrm{v})$ y la adición de eosulfato de fenazina al CIV de embriones bovinos, inhibe la síntesis de ácidos grasos y mejora la supervivencia a la criopreservación. En otro estudio Gómez y cols., (2008) establecieron que los blastocistos PIV cultivados en medio SOF con BSA pero sin suero mostraron una mayor tasa de supervivencia a la vitrificación frente a embriones cultivados en SOF con suero. Del mismo modo, se ha descrito que el tratamiento con forskolina antes de la vitrificación mejora la supervivencia a la criopreservación de embriones bovinos (Bos indicus) producidos in vitro, obteniéndose mejores índices de gestación después de la transferencia a receptoras (Sánchez y cols., 2013).

\subsubsection{Expresión génica}

El transcriptoma se define como el conjunto completo de moléculas de ARN expresadas en una célula u organismo durante una etapa específica del desarrollo o condición fisiológica. Por lo tanto, el análisis de los patrones de expresión de genes que pueden estar implicados en la traducción de proteínas 
esenciales en el desarrollo embrionario proporciona información valiosa sobre los posibles efectos ejercidos por factores ambientales sobre el embrión temprano (Cagnone y cols., 2012; Dufort y cols., 2015). Las proteínas que traducen los genes expresados durante el desarrollo embrionario están implicadas en diversos procesos biológicos que incluyen metabolismo, señales de GFs y citoquinas, adaptación al estrés, transcripción y traducción, regulación epigenética de la transcripción, apoptosis, compactación y formación de blastocisto (Wrenzycki y cols., 2005; Ross y Chitwood, 2012).

El medio de cultivo de embriones después de la FIV puede tener un efecto drástico sobre el patrón de expresión génica en el embrión, lo que a su vez afectará al desarrollo normal del blastocisto. Así, se han evidenciado cambios en los patrones de expresión génica no solo cuando se comparan sistemas de cultivo in vivo e in vitro, sino también entre diferentes sistemas de CIV (Eckert y Niemann, 1998; Wrenzycki y cols., 2001; Rizos y cols., 2002; Lonergan y cols., 2003; Cagnone y cols., 2012; Van der Weijden y cols., 2017).

La sensibilidad de los análisis de expresión génica han mejorado mucho en los últimos años, y hoy en día diferentes técnicas transcriptómicas permiten analizar la expresión génica en ovocitos y embriones bovinos o incluso en blastómeros individuales (Chitwood y cols., 2013; Jiang y cols., 2014).

\subsubsection{Dimorfismo sexual}

Los embriones bovinos macho y hembra difieren no solo en los cromosomas sexuales, sino también en la expresión génica de genes presentes en los cromosomas autosómicos (Bermejo-Álvarez y cols., 2010; Lowe y cols., 2015), 
la configuración epigenética (Bermejo-Álvarez y cols., 2008; Dobbs y cols., 2013), la regulación proteómica (Gómez y cols., 2013) y en los perfiles metabolomicos (Muñoz y cols., 2013; Gómez y cols., 2016; Gómez y cols., 2017; Gómez y cols., 2018).

En los mamíferos, los cambios en el entorno materno durante el período preimplantacional afectan de manera diferente a embriones machos y hembras, lo cual también se evidencia en los fenotipos de recién nacidos y adultos (Hansen y cols., 2016). La proporción de embriones macho/hembra puede ser modificada por factores ambientales tales como la dieta materna in vivo y la composición de los medios de cultivo de embriones in vitro. Los embriones macho y embriones hembra difieren en su fisiología durante los estadíos de desarrollo previos a la implantación (Gardner y cols., 2010). De igual manera, el microambiente del medio de cultivo, los niveles de nutrientes, el tipo de suplemento proteico y la concentración de oxígeno pueden afectar al desarrollo embrionario de manera específica dependiendo del sexo del embrión (Wale y Gardner, 2015).

Durante el período preimplantacional los embriones macho y hembra son genéticamente idénticos en sus cromosomas autosómicos, aunque la regulación transcripcional es específica para cada sexo. En bovino, durante la primera división celular, los embriones macho se dividen antes que los embriones hembra (Gutiérrez-Adán, 1996; Pérez-Cerezales y cols., 2018) y el dimorfismo sexual continua siendo apreciable en el estadío de mórula (Denicol $y$ cols., 2015). En el estadío de blastocisto, un tercio de todos los genes que se expresan difieren entre embriones macho y hembra, existiendo una mayor expresión de genes ligados al cromosoma $X$ en embriones femeninos 
(Bermejo-Álvarez y cols., 2010). En algunas condiciones de CIV, se han señalado diferencias dependientes del sexo del embrión, como la velocidad de desarrollo embrionario, la supervivencia después de la vitrificación, el número de células en la etapa de blastocito, los porcentajes de apoptosis y el metabolismo (Gutiérrez-Adán y cols., 2006; Ghys y cols., 2016; Gómez y cols., 2018).

Entre las diferencias metabólicas específicas del sexo del embrión, el metabolismo de la glucosa es una de las más estudiadas, particularmente con respecto a la vía de la pentosa fosfato (Kimura y cols., 2005; Sturmey y cols., 2010). En bovino, el aumento de la expresión de la glucosa 6-fosfato deshidrogenasa (G6PD) en blastocistos hembra (Gutiérrez-Adán, y cols., 2000, Wrenzycki, y cols., 2002) y de SLC2A3 en blastocistos macho (Morton, y cols., 2007), provoca diferencias en el metabolismo de la glucosa entre embriones de ambos sexos. Sin embargo, el metabolismo de la glucosa no destacó como una vía sexualmente dimórfica en un estudio de Bermejo Álvarez y cols., (2010a) sobre las diferencias globales de transcritos de blastocistos bovinos macho y hembra. Así, el análisis de transcritos específicos implicados en la glucólisis anaerobia o la vía de la pentosa fosfato no mostró una desequilibrio claro en la proporción de sexos (Bermejo Álvarez y cols., 2011a). Además, Cagnone y cols., (2011) señalaron que la respuesta transcripcional de blastocistos bovinos a la presencia de glucosa no está relacionada con el sexo. De igual manera, Gómez y cols., 2013 indicaron que la concentración de Dfructosa aumentó en el fluido uterino (FU) bovino en presencia de embriones PIV hembra, comparado con el FU con embriones PIV macho, mientras que los 
niveles de D-glucosa fueron similares. Por lo tanto, el metabolismo de la glucosa asociado al dimorfismo sexual no está exento de controversias.

Por otro lado, en un análisis global de expresión génica de blastocistos bovinos PIV, la actividad de la mitocondria y la traducción de proteínas, la proteólisis y el transporte de proteína se encontraron afectadas por el sexo del embrión (Bermejo Álvarez y cols., 2010). Además, los embriones macho y hembra difieren en el ADN mitocondrial (Bermejo Álvarez y cols., 2008) y el metabolismo de aminoácidos (Sturmey y cols., 2010). Las diferencias específicas por sexo en estas y otras rutas (implicadas en la apoptosis y la comunicación materno embrionaria) proporcionan una base molecular para dar respuestas específicas del sexo a deficiencias nutricionales, y también pueden utilizarse para desarrollar métodos no invasivos de diagnóstico del sexo de los embriones (Gómez y cols., 2016; Sturmey y cols., 2010).

En un estudio reciente, Heras y cols., (2016) demostraron que las condiciones subóptimas de CIV pueden tener un impacto diferente en los embriones de acuerdo con su sexo. Así, los embriones macho PIV tienen tres veces más genes expresados diferencialmente comparados con embriones in vivo y con embriones hembra PIV. Además, el útero de la vaca proporciona a los embriones macho un entorno más embriotrófico que a los embriones hembra (Gómez y cols., 2013). Por lo tanto, el estudio del dimorfismo sexual puede ayudar a diseñar medios de CIV adaptados al sexo del embrión. 


\subsection{La viabilidad del embrión en las receptoras}

\subsubsection{Establecimiento de la gestación}

Los índices de gestación después de la transferencia son un muy buen indicador de la viabilidad de los embriones bovinos PIV. Por lo general, los embriones PIV se transfieren usando la vía transcervical -no invasiva- al igual que los embriones recogidos in vivo. La edad y estadío del embrión in vitro junto con la fase del ciclo estral de la receptora se deben sincronizar estrechamente (Hasler y cols., 2014; Randi y cols., 2015)

En bovinos, el período embrionario discurre entre la fecundación y el final de la organogénesis -día 42 de gestación-, a partir del cual se inicia el período fetal. En la luz del útero el blastocisto eclosionado se elonga antes de implantarse, adquiriendo sucesivamente formas esférica, ovoide y filamentosa. La elongación del blastocisto coincide con la gastrulación (diferenciación de capas germinativas) y el embrión se denomina conceptus. El establecimiento de la gestación implica el crecimiento y elongación del conceptus, su reconocimiento por el útero, la implantación y la placentación (Spencer y cols., 2008).

La elongación está controlada por la progesterona (P4), que actúa regulando el crecimiento del TF (Spencer y cols., 2007). El conceptus crece dentro de la luz uterina del cuerno ipsilateral al cuerpo lúteo, espacio que ocupa por completo hacia el día 17 de gestación. Durante la elongación el conceptus desarrolla una capacidad creciente para secretar interferón-tau (IFN-т; Kubisch, 1998; Bertolini y cols., 2002), el cual modula la síntesis de prostaglandinas en el endometrio para bloquear los pulsos luteolíticos de la prostaglandina $\mathrm{PGF}_{2} \alpha$ (Spencer $y$ cols., 2007) y para favorece la secreción de prostaglandina E2 (Sponchiado y 
cols., 2017). La producción de IFN-T, que se realiza en las células del TF (Spencer y Bazer, 2004; Robinson y cols., 2008), es la señal para el reconocimiento materno de la gestación y alcanza su nivel máximo entre los días 15 y 17 de gestación (Wolf y cols., 2003).

Se ha descrito ampliamente que la expresión de IFN-T es evidente tan pronto como se desarrollan las células del TF en los estadíos de morula tardía y blastocisto temprano en embriones bovinos producidos in vitro e in vivo (Hernández-Ledezma y cols., 1993; Kubisch y cols., 1998; Bertolini y cols., 2002; Lonergan y cols., 2003). Aunque, los blastocistos bovinos de día 7 producidos in vivo o in vitro producen cantidades muy bajas de IFN-T (Kubisch y cols., 1998), se ha demostrado recientemente que el blastocisto de día 7 (no eclosionado) es capaz de estimular la expresión de genes inducidos por el IFNT en la unión uterotubal de la vaca gestante (Sponchiado y cols., 2017).

El éxito de la gestación en el ganado bovino precisa de funciones endometriales tempranas dependientes e independientes del embrión. Así, la proximidad física del embrión regula la función endometrial de manera paracrina, en tanto que la regulación del transcriptoma endometrial independiente del embrión puede favorecer etapas posteriores del desarrollo embrionario, tales como la elongación y la implantación (Sponchiado y cols., 2017). La implantación del conceptus en el útero comienza aproximadamente en el día 19 de la gestación y en el día 20 se desarrollan las primeras vellosidades placentarias. Alrededor del día 27 el entramado de vellosidades situados frente a las carúnculas uterinas da forma los primeros cotiledones. 
Actualmente en bovinos, la mayoría de diagnósticos de gestación se llevan a cabo mediante ultrasonografía transrectal del tracto reproductivo para detectar la presencia o ausencia del embrión generalmente a partir del día 27 o 28. Además, la ultrasonografía transrectal permite evaluar la dinámica folicular, la morfología del cuerpo lúteo y la viabilidad embrionaria ó fetal, entre otras aplicaciones (Ginther, 2014).

Los embriones bovinos PIV producen menores índices de gestación que los embriones producidos in vivo mediante MOET (Pontes et al., 2009; Siqueira et al., 2009). Así, los índices de gestación después de la transferencia de embriones bovinos PIV son entre $10 \%$ y $30 \%$ más bajos que las gestaciones a partir de embriones in vivo (de Sousa y cols., 2017; Pontes y cols., 2009; Rasmussen y cols., 2013). Los índices de gestación obtenidos después de la transferencia de embriones dependen tanto de la receptividad de la receptora como de la viabilidad del embrión. En este sentido, se han reportado índices de gestación de embriones bovinos PIV significativamente menores en vacas (33.1\%) que en novillas (44.0\%) (Aoki y cols., 2004). Además, los embriones bovinos producidos in vitro transferidos en vacas de primer parto también producen menores índices de concepción (39.6\%) que las novillas (47.5\%) (van Wagtendonk-de Leeuw y cols., 1997).

\subsubsection{Pérdidas embrionarias tempranas y aborto}

La mayoría de las pérdidas de embriones ocurren entre el día 8 y el día 16 de gestación coincidiendo con el reconocimiento materno del embrión. El aborto es la interrupción de la gestación después de la organogénesis, antes de que el 
feto expulsado pueda sobrevivir. Si la gestación termina antes de que se complete la organogénesis entre la fecundación y el día 42 de gestación, se denomina muerte embrionaria temprana (Walsh y cols., 2011), mientras que la expulsión de fetos sin vida desde el día 42 hasta el final de gestación se denomina aborto. La mortalidad fetal a término se caracteriza por la evidencia de un ternero muerto sin que sus pulmones hayan llegado a insuflarse.

En bovinos, una de las principales causas del bajo éxito reproductivo es la mortalidad embrionaria temprana (Santos y cols., 2004). Existe una pérdida significativa de gestaciones tras la transferencia de embriones in vitro que principalmente se produce durante las etapas más tempranas de la gestación. Los mayores porcentajes de pérdidas embrionarias en la gestación bovina ocurren hasta día 42 (final de la organogénesis) en comparación con el período fetal o el período perinatal (desde el parto hasta el día 28 posparto) (Farin y cols., 2001, 2006).

Sreenan y Diskin (1986) calcularon un índice de mortalidad embrionaria y fetal del $40 \%$ para vacas con producciones moderadas de leche, donde el $75 \%$ de las pérdidas embrionarias fueron entre los días 8 y 16 después de la inseminación artificial (IA). En sistemas de producción de leche en pastoreo, tras la IA, los índices de pérdidas embrionarias y fetales evaluados entre los días 28 y 84 de gestación fueron similares para vacas leche $(7,2 \%)$ y novillas (6,1\%). Además, un $47.5 \%$ de las pérdidas embrionarias totales ocurrieron entre los días 28 y 42 de gestación (Silke y cols., 2001).

Después de la transferencia de embriones bovinos PIV se han señalado porcentajes del $45 \%$ de pérdidas embrionarias en día 14 , coincidiendo con el 
período de reconocimiento materno de la gestación (McMillan y cols., 1997; Mamo y cols., 2011). Un análisis retrospectivo de 2.300 embriones PIV transferidos a receptoras reveló una tasa de supervivencia promedio del $50 \%$ al día 24 , del $40 \%$ al día 60 y del 30\% al término de la gestación (Peterson y Lee, 2003). Además, Muñoz y cols., (2014), después de la transferencia de embriones PIV frescos, obtuvieron 59\% de gestaciones a día 60 y $52 \%$ de nacimientos, mientras que, con embriones PIV vitrificados señalaron $36 \%$ de gestaciones a día 60 y $31 \%$ de nacimientos. Es importante destacar que las mayores proporciones de pérdidas embrionarias y fetales varían con los medios y sistemas de CIV utilizados (Farin y cols., 2006).

Aunque los abortos son menos abundantes que las pérdidas embrionarias tempranas, aquellos causan perjuicios económicos graves, particularmente en rebaños de parto estacional. La interrupción tardía de la gestación impide a menudo reinsertar a tiempo las vacas en programas de reproducción, lo cual aumenta las tasas de sacrificio (Diskin y cols., 2012).

\subsubsection{Resultados perinatales con embriones producidos in vitro}

Las anormalidades más excepcionales observadas en el período perinatal después de la transferencia de embriones PIV es la aparición de terneros de mayor peso al nacimiento en comparación con los embriones producidos in vivo. Los elevados porcentajes de muerte perinatal asociados a las gestaciones de embriones PIV son atribuibles en gran medida a la distocia provocada por fetos de gran tamaño durante el parto (Behboodi, 1995; Farin, 2006). 
Los terneros nacidos a partir de la transferencia individual de embriones frescos producidos in vitro presentan mayores pesos al parto, y períodos de gestación más largos, que los terneros de IA y ET gemelares (Sinclair, 1995). Se ha descrito un elevado peso al parto asociado a embriones producidos in vitro en varias razas bovinas tanto en Bos taurus como en Bos indicus (Kruip y Den Daas, 1997; van Wagtendonk-de Leeuw 1998; McEvoy, 1998; Numabe 2000; Bertolini 2002). Así, en Holstein, más del 34\% de los terneros producidos in vitro pueden pesar más de $50 \mathrm{~kg}$ al parto (Kruip y Den Daas, 1997; Lazzari, 2002). En Gyr, la transferencia de embriones frescos PIV dio como resultado un mayor peso al nacer que los controles de IA, efecto más acusado en los terneros machos (Camargo, 2010).

Tras la gestación de embriones bovinos PIV, el mayor peso al nacimiento de los terneros refleja una desproporción orgánica (Farin, 1995; Bertolini, 2004). Curiosamente, los terneros de embriones frescos PIV mostraron no solo mayores pesos al nacer, sino también concentraciones elevadas de fructosa en plasma después del nacimiento en comparación con los controles in vivo (Bertolini, 2004).

La facilidad de parto depende de la duración de la gestación y del peso de los terneros al parto, y se ve afectada por el sexo fetal, el fenotipo de los progenitores, la nutrición materna, el ambiente durante el último trimestre de gestación y el medio de CIV (Mee, 2008). 


\subsubsection{Salud perinatal de terneros producidos in vitro}

Los factores de riesgo prenatales pueden afectar negativamente algunos rasgos de la progenie. Por ejemplo, la nutrición subóptima de los progenitores, el estrés gestacional, la exposición a sustancias químicas y las tecnologías reproductivas usadas en los programas de mejora genética inciden en el crecimiento posparto, la eficiencia alimenticia, la producción de leche, la composición de la canal, el bienestar animal y el potencial reproductivo (Sinclair y cols., 2016).

Las modificaciones en la expresión de genes que no son resultado de una alteración en el DNA, pero que son heredables, se denominan modificaciones/cambios epigenéticos. Las células en tejidos adultos tienen la capacidad de mantener una huella epigenética del desarrollo embrionario (Hon y cols., 2013) o incluso de generaciones pasadas. Por lo tanto, el estudio de los efectos de las tecnologías reproductivas en el patrón epigenético de los embriones y la descendencia resultante ha ganado más atención en los últimos años.

El modelo de producción bovino tanto de carne como de leche dificulta la evaluación de los resultados adversos en la salud adulta de la progenie y, por lo general, solo se obtiene información de los efectos clínicamente observados en animales jóvenes. La industria bovina no acostumbra a dar parte de problemas en la salud perinatal y adulta de la descendencia (Blondin 2016), aunque aún se observa un mayor peso de los terneros al nacimiento cuando provienen de embriones PIV (Bonilla y cols., 2014). Además, los terneros nacidos de embriones PIV usando semen sexado inverso, son más pesados en 
comparación a los terneros nacidos después de la IA, mientras que los terneros nacidos de embriones PIV con semen convencional tienen un peso de nacimiento intermedio (Siqueira y cols., 2017).

La función de un animal adulto depende no solo del entorno al que estuvo expuesto después del nacimiento sino también de las condiciones del ambiente al que estuvo expuesto durante el desarrollo embrionario, desde la fecundación hasta las primeras diferenciaciones en el estadío de blastocisto (Fleming $y$ cols., 2015). 


\subsection{Referencias}

Abe H, Yamashita S, Satoh T \& Hoshi H. (2002). Accumulation of cytoplasmic lipid droplets in bovine embryos and cryotolerance of embryos developed in different culture systems using serum-free or serum-containing media. Mol Reprod Dev, 61(1), 57-66.

Aoki S, Murano S, Miyamura M, Hamano S, Terawaki Y, et al., (2004). Factors affectingon embryo transfer pregnancy rates of in vitro-produced bovine embryos. Reprod.Fertil.Develop.16:206 (Abstr.)

Almiñana C, Cuello C. (2015). What is new in the cryopreservation of embryos? Anim Reprod 12:418-427.

Arav A. (2014). Cryopreservation of oocytes and embryos. Theriogenology 81:96-102.

Asselin E, Goff AK, Bergeron H \& Fortier MA. (1996). Influence of sex steroids on the production of prostaglandins $\mathrm{F} 2 \alpha$ and $\mathrm{E} 2$ and response to oxytocin in cultured epithelial and stromal cells of the bovine endometrium. Biol Reprod, 54(2), 371-379.

Avilés M, Gutiérrez-Adán A \& Coy P. (2010). Oviductal secretions: will they be key factors for the future ARTs?. Mol Hum Reprod, 16(12), 896-906.

Baltz JM. (2001). Osmoregulation and cell volume regulation in the preimplantation embryo. Curr Top Dev Biol. 52:55-106.

Baruselli PS, Batista EOS, Vieira IM, Ferreira RM, Guerreiro BG, et al. (2016). Factors that interfere with oocyte quality for in vitro production of cattle embryos: effects of different developmental and reproductive stages. Anim. Reprod. 13: 264-272.

Bavister, B.D. (1981) Substitution of a synthetic polymer for protein in a mammalian gamete culture system. J. Exp. Zool. , 217, 45-51.

Behboodi E, Anderson GB, BonDurant RH, Cargill SL, Kreuscher BR, et al. (1995). Birth of large calves that developed from in vitro-derived bovine embryos. Theriogenology 44:227-232.

Beja-Pereira, A., Caramelli, D., Lalueza-Fox, C., Vernesi, C., Ferrand, N., et al. (2006). The origin of European cattle: evidence from modern and ancient DNA. Proceedings of the National Academy of Sciences, 103(21), 8113-8118.

Bermejo-Alvarez P, Rizos D, Rath D, Lonergan P \& Gutierrez-Adan A. (2008). Epigenetic differences between male and female bovine blastocysts produced in vitro. Physiological Genomics, 32(2), 264-272. 
Bermejo-Álvarez P, Rizos D, Rath D, Lonergan P, Gutiérrez-Adán A. (2010). Sex determines the expression level of one third of the actively expressed genes in bovine blastocysts. Proc Natl Acad Sci USA. 107:3394-3399.

Bermejo-Alvarez P, Rizos D, Lonergan P \& Gutierrez-Adan A. (2011). Transcriptional sexual dimorphism during preimplantation embryo development and its consequences for developmental competence and adult health and disease. Reproduction, 141(5), 563-570.

Bertolini M, Moyer A, Mason J et al. (2004). Evidence of increased substrate availability to in vitro-derived bovine fetuses and association with accelerated conceptus growth. Reproduction. 128:341-354.

Bertolini M, Mason J, Beam S et al. (2002). Morphology and morphometry of in vivo- and in vitro-produced bovine concepti from early pregnancy to term and association with high birth weights. Theriogenology 58:973994.

Block J, Hansen PJ, Loureiro B, \& Bonilla L. (2011). Improving post-transfer survival of bovine embryos produced in vitro: actions of insulin-like growth factor-1, colony stimulating factor-2 and hyaluronan. Theriogenology, 76(9), 1602-1609.

Bogliotti, Y.S., Wu, J., Vilarino, M., Okamura, D., Soto, D. A., et al., (2018). Efficient derivation of stable primed pluripotent embryonic stem cells from bovine blastocysts. Proceedings of the National Academy of Sciences, 201716161.

Boni R, Tosti E, Roviello S \& Dale B (1999). Intracellular communication in in vivo- and in vitro-produced bovine embryos. Biol Reprod 61 1050-1055.

Bonilla L, Block J, Denicol AC, Hansen PJ. (2014). Consequences of transfer of an in vitro -produced embryo for the dam and resultant calf. J Dairy Sci. 97: 229- 239.

Block J, Hansen PJ, Loureiro B \& Bonilla L. (2011). Improving post-transfer survival of bovine embryos produced in vitro: actions of insulin-like growth factor-1, colony stimulating factor-2 and hyaluronan. Theriogenology. 76: 1602-1609.

Blondin P, Bousquet D, Twagiramungu H, Barnes F, Sirard M-A. (2002). Manipulation of follicular development to produce developmentally competent bovine oocytes. Biol Reprod: 66:38-43.

Blondin, P. (2015). Status of embryo production in the world. Anim Reprod.12:356-358.

Blondin P. (2017). Logistics of large scale commercial IVF embryo production. Reproduction, Fertility and Development, 29(1), 32-36. 
Botigelli, R. C., Razza, E. M., Pioltine, E. M., \& Nogueira, M. F. G. (2017). New approaches regarding the in vitro maturation of oocytes: manipulating cyclic nucleotides and their partners in crime. JBRA assisted reproduction, 21(1), 35.

Breininger E, Cetica C, Beconi M. (2010) Capacitation inducers act through diverse intracellular mechanisms in cryopreserved bovine sperm. Theriogenology. 74:1036-1049.

Byrne AT, Southgate J, Brison DR, Leese HJ. Analysis of apoptosis in the preimplantation bovine embryo using TUNEL. J Reprod Fertil 1999; 117:97-105.

Bunel A, Jorssen EP, Merckx E, Leroy JL, Bols PE \& Sirard MA. (2015). Individual bovine in vitro embryo production and cumulus cell transcriptomic analysis to distinguish cumulus-oocyte complexes with high or low developmental potential. Theriogenology, 83(2), 228-237.

Cagnone GL, Dufort I, Vigneault C, Sirard MA. 2011. Differential gene expression profile in bovine blastocysts resulting from hyperglycemia exposure during early cleavage stages. Biol Reprod: Epub ahead of print (PMID: 22075474).

Cagnone GL, Dufort I, Vigneault C \& Sirard MA (2012). Differential gene expression profile in bovine blastocysts resulting from hyperglycemia exposure during early cleavage stages. Biol Reprod 86-50.

Cagnone, G. L., \& Sirard, M. A. (2013). Transcriptomic signature to oxidative stress exposure at the time of embryonic genome activation in bovine blastocysts. Molecular reproduction and development, 80(4), 297-314.

Cagnone, G. L., \& Sirard, M. A. (2016). The embryonic stress response to in vitro culture: insight from genomic analysis. Reproduction, REP-16-0391.

Camargo L, Freitas C, de Sa W, Ferreira A, Serapiao R, Viana J.(2010). Gestation length, birth weight and offspring gender ratio of in vitroproduced Gyr (Bos indicus) cattle embryos. Anim Reprod Sci 120:10-15.

Caamaño, J. N., Gómez, E., Trigal, B., Muñoz, M., Carrocera, S., Martín, D., et al. (2015). Survival of vitrified in vitro-produced bovine embryos after a one-step warming in-straw cryoprotectant dilution procedure. Theriogenology 83: 881-890.

Carolan C, Lonergan P, Khatir, H \& Mermillod P. (1996). In vitro production of bovine embryos using individual oocytes. Molecular Reproduction and Development: Incorporating Gamete Research, 45(2), 145-150.

Chitwood JL, Rincon G, Kaiser GG, Medrano JF \& Ross PJ. (2013). RNA-seq analysis of single bovine blastocysts. BMC genomics, 14(1), 350. 
Conti, M., \& Franciosi, F. (2018). Acquisition of oocyte competence to develop as an embryo: integrated nuclear and cytoplasmic events. Human reproduction update, 24(3), 245-266.

Cronin JG, Turner ML, Goetze L, Bryant CE \& Sheldon IM. (2012). Toll-like receptor 4 and MYD88-dependent signaling mechanisms of the innate immune system are essential for the response to lipopolysaccharide by epithelial and stromal cells of the bovine endometrium. Biology of reproduction, 86(2), 51-1.

Crosier AE, Farin PW, Dykstra MJ, Alexander JE, Farin CE. (2000). Ultrastructural morphometry of bovine compact morulae produced in vivo or in vitro. Biol Reprod 62:1459-1465

Crosier AE, Farin PW, Dykstra MJ, Alexander JE \& Farin CE. (2001). Ultrastructural morphometry of bovine blastocysts produced in vivo or in vitro. Biol. Reprod. 64, 1375-1385.

Denicol AC, Lea ̃ BC, Dobbs KB, Mingoti GZ \& Hansen PJ. (2015). Influence of sex on basal and Dickkopf-1 regulated gene expression in the bovine morula. PLoS One 10, e0133587.

De Sousa RV, da Silva Cardoso CR, Butzke G, Dode MAN, Rumpf R \& Franco, M. M. (2017). Biopsy of bovine embryos produced in vivo and in vitro does not affect pregnancy rates. Theriogenology, 90, 25-31.

Dinnyes A, Lonergan P, Fair T, Boland MP, Yang X. (1999). Timing of the first cleavage post-insemination affects cryosurvival of in vitro-produced bovine blastocysts. Mol Reprod Dev. 53:318-24.

Dinnyes A., Nedambale T. L. 2009. Cryopreservation of manipulated embryos: tackling the double jeopardy. Reprod. Fertil. Dev. 21: 45-59.

Diskin MG, Parr MH \& Morris DG. (2012). Embryo death in cattle: an update. Reproduction, Fertility and Development, 24(1), 244-251.

Dobbs KB, Rodriguez M, Sudano MJ, Ortega MS, Hansen PJ. (2013). Dynamics of DNA methylation during early development of the preimplantation bovine embryo. PLOS One. 8:e66230.

Ducharme NA, Bickel PE. (2008). Minireview: lipid droplets in lipogenesis and lipolysis. Endocrinology;149(3):942-9.

Duque, P., Hidalgo, C. O., Gómez, E., Pintado, B., Facal, N., and Díez, C. (2003). Macromolecular source as dependent on osmotic pressure and water source: effects on bovine in vitro embryo development and quality. Reprod. Nutr. Dev. 43, 487-496.

Dufort, I., Robert, C., and Sirard, M. A. (2015). Studying bovine early embryo transcriptome by microarray. Methods Mol. Biol. 1222, 197-208. 
Dunning KR, Cashman K, Russell DL, Thompson JG, Norman RJ \& Robker RL. (2010). Beta-oxidation is essential for mouse oocyte developmental competence and early embryo development. Biology of reproduction, 83(6), 909-918.

Duranthon V, Chavatte-Palmer P. (2018). Long term effects of ART: What do animals tell us? Mol Reprod Dev. 85(4):348-368

Eckert $\mathrm{J}$ and Niemann $\mathrm{H}$ (1998). mRNA expression of leukaemia inhibitory factor (LIF) and its receptor subunits glycoprotein 130 and LIF-receptorbeta in bovine embryos derived in vitro or in vivo. Molecular Human Reproduction 4 957-965.

Fabian D, Koppel J, Maddox-Hyttel. (2005). Apoptotic processes during mammalian preimplantation development. Theriogenology, 64(2):221-31.

Farin PW, Crosier AE, \& Farin CE. (2001). Influence of in vitro systems on embryo survival and fetal development in cattle. Theriogenology, 55(1), 151-170.

Farin P, Farin C. (1995). Transfer of bovine embryos produced in vivo or in vitro: survival and fetal development. Biol Reprod. 52:676-682.

Farin P, Piedrahita J, Farin C. (2006). Errors in development of fetuses and placentas from in vitro-produced bovine embryos. Theriogenology 65:178-191.

Farin CE, Farmer WT \& Farin PW. (2010). Pregnancy recognition and abnormal offspring syndrome in cattle. Reprod. Fertil. Dev. 22 75-87.

Feichtinger M, Vaccari E, Carli L, Wallner E, Mädel U, et al. (2017). Noninvasive preimplantation genetic screening using array comparative genomic hybridization on spent culture media: a proof-of-concept pilot study. Reproductive biomedicine online, 34(6), 583-589.

Ferreira, E. M., Vireque, A. A., Adona, P. R., Meirelles, F. V., Ferriani, R. A. y Navarro, P. A. (2009). Cytoplasmic maturation of bovine oocytes: structural and biochemical modifications and acquisition of developmental competence, Theriogenology, 71(5): 836-48.

Fields SD, Hansen PJ \& Ealy AD (2011). Fibroblast growth factor requirements for in vitro development of bovine embryos. Theriogenology. 75 1466-1475.

Fleming TP, Velázquez MA, Eckert JJ. (2015). Embryos, DOHaD and David Barker. J Dev Orig Health Dis. 6(5):377-383.

Francis G.L. (2010). Albumin and mammalian cell culture: implications for biotechnology applications. Cytotechnology 62, 1-16. 
Galli C, Duchi R, Crotti G, Turini P, Ponderato N, Colleoni S, Lagutina I, Lazzari G.(2003). Bovine embryo technologies. Theriogenology. 59:599-616.

Gad A, Hoelker M, Besenfelder U, Havlicek V, Cinar U, Rings F, et al. (2012) Molecular mechanisms and pathways involved in bovine embryonic genome activation and their regulation by alternative in vivo and in vitro culture conditions. Biol Reprod. 87: 100.

Gasperin BG, Barreta MH, Santos JT, Ferreira R, Neves JP, et al. (2016). OilFree Culture System for in Vitro Bovine Embryo Production. Italian Journal of Animal Science, 9:2.

Gardner DK, Pool TB, Lane M. (2000). Embryo nutrition and energy metabolism and its relationship to embryo growth, differentiation and viability. Semin Reprod Med. 18:205-18.

Gardner DK, Surrey E, Minjarez D, Leitz A, Stevens J \& Schoolcraft WB. (2004). Single blastocyst transfer: a prospective randomized trial. Fertility and sterility, 81(3), 551-555.

Gardner DK. (2008). Dissection of culture media for embryos: the most important and less important components and characteristics. Reprod Fertil Dev. 20(1): 9-18.

Genicot G, Leroy J, Van Soom A \& Donnay I. (2005). The use of a fluorescent dye, Nile red, to evaluate the lipid content of single mammalian oocytes. Theriogenology, 63(4), 1181-1194.

Gardner DK, Larman MG \& Thouas GA. (2010). Sex-related physiology of the preimplantation embryo. MHR: Basic science of reproductive medicine, 16(8), 539-547.

Gjorret JO, Knijin HM, Dieleman SJ, Avery B, Larsson LI, Hyttel M. (2003). Chronology of apoptosis in bovine embryos produced in vivo and in vitro. Biol Reprod 69:1193-200.

Graf A, Krebs S, Heininen-Brown M, Zakhartchenko V, Blum H, et al. (2014). Genome activation in bovine embryos: review of the literature and new insights from RNA sequencing experiments. Anim Reprod Sci, 149:46-58.

Gray CA, Taylor KM, Ramsey WS, Hill JR, Bazer FW, et al. (2001). Endometrial glands are required for preimplantation conceptus elongation and survival. Biology of reproduction, 64(6), 1608-1613.

Gualtieri R, Santella L, Dale B. (1992). Tight junctions and cavitation in the human pre-embryo. Mol Reprod Dev. 32:81-87.

Gómez E and Diez C. (2000). Effects of glucose and protein sources on bovine embryo development in vitro. Anim Reprod Sci 58,23-37. 
Gómez E, Rodríguez A, Muñoz M, Caamaño JN, Hidalgo CO, et al. (2008). Serum free embryo culture medium improves in vitro survival of bovine blastocysts to vitrification. Theriogenology, 69(8), 1013-1021.

Gómez E, Caamaño JN, Corrales FJ, Diez C, Correia-Álvarez E, et al. (2013). Embryonic sex induces differential expression of proteins in bovine uterine fluid. J Proteome Res 12:1199-210.

Gómez E, Correia-Álvarez E, Caamaño JN, Díez C, Carrocera S, et al. (2014). Hepatoma-derived growth factor: from the bovine uterus to the in vitro embryo culture. Reproduction. 148 (4): 353-365

Gómez E., Muñoz M. (2015). Multiple-embryo transfer for studying very early maternal-embryo interactions in cattle. Reproduction. 150(2): R35R43.

Gómez E, Muñoz M, Simó C, lbáñez C, Carrocera S, et al. (2016). Noninvasive metabolomics for improved determination of embryonic sex markers in chemically defined culture medium. $J$ Chromatogr $A$; 1474:138-44.

Gómez E, Sánchez-Calabuig MJ, Martin D, Carrocera S, Murillo A, et al. (2018a). In vitro cultured bovine endometrial cells recognize embryonic sex. Theriogenology, 108, 176-184.

Gómez E, Carrocera S, Martin D, Herrero P, Canela N \& Muñoz, M. (2018b). Differential release of cell-signaling metabolites by male and female bovine embryos cultured in vitro. Theriogenology, 114, 180-184.

Gordon I. (2003). Laboratory production of cattle embryos, $2^{\text {nd }}$ edition. Cambridge, MA, USA: CABI Publishing.

Goovaerts IG, Leroy JL, Jorssen EP \& Bols PE. (2010). Noninvasive bovine oocyte quality assessment: possibilities of a single oocyte culture. Theriogenology 74, 1509-1520.

Goudet G, Mugnier S, Callebaut I \& Monget, P. (2008). Phylogenetic analysis and identification of pseudogenes reveal a progressive loss of zona pellucida genes during evolution of vertebrates. Biology of reproduction, 78(5), 796-806.

Gilchrist RB, Ritter LJ \& Armstrong DT. (2004). Oocyte-somatic cell interactions during follicle development in mammals. Anim Reprod Sci. 82-83: 431-446

Guo Y, Cordes KR, Farese RV \& Walther TC. (2009). Lipid droplets at a glance. J Cell Sci, 122(6), 749-752.

Gutiérrez-Adán A, Behboodi E, Andersen GB, Medrano JF \& Murray JD. (1996). Relationship between stage of development and sex of bovine 
IVM-IVF embryos cultured in vitro versus in the sheep oviduct. Theriogenology, 46(3), 515-525.

Gutiérrez-Adán A, Oter M, Martínez-Madrid B, Pintado B and De La Fuente J (2000). Differential expression of two genes located on the $\mathbf{X}$ chromosome between male and female in vitro-produced bovine embryos at the blastocyst stage. Molecular Reproduction and Development 55 146-151.

Gutiérrez-Adán A, Perez-Crespo M, Fernandez-Gonzalez R, Ramirez MA, Moreira P, et al. (2006). Developmental Consequences of Sexual Dimorphism During Pre-implantation Embryonic Development. Reproduction in Domestic Animals, 41(s2), 54-62.

Ghys E, Dallemagne M, De Troy D, Sauvegarde C, Errachid A \& Donnay I. (2016). Female bovine blastocysts are more prone to apoptosis than male ones. Theriogenology, 85(4), 591-600.

Hansen PJ. (2015). Developmental programming in the preimplantation period: can it be exploited to enhance postnatal function in cattle? Anim Reprod,12:428-436.

Hansen PJ, Dobbs KB, Denicol AC \& Siqueira LG. (2016). Sex and the preimplantation embryo: implications of sexual dimorphism in the preimplantation period for maternal programming of embryonic development. Cell and tissue research, 363(1), 237-247.

Hasler JF. (2003). The current status and future of commercial embryo transfer in cattle. Anim Reprod Sci. 79: 245-64.

Hasler J, Henderson W, Hurtgen P et al., (1995). Production, freezing and transfer of bovine IVF embryos and subsequent calving results. Theriogenology, 43:141-152.

Hasler J. Embryo transfer and in vitro fertilization. (2007). In: Schatten $\mathrm{H}$, Constantinescu GM (eds) Comparative Reproductive Biology. Ames, IA: Blackwell Publishing. pp. 171-211.

Hasler JF \& Barfield JP. (2014). In Vitro Fertilization-Bovine Reproduction. 758-770.

Heras S, De Coninck DI, Van Poucke M, Goossens K, Pascottini O B, et al. (2016). Suboptimal culture conditions induce more deviations in gene expression in male than female bovine blastocysts. BMC genomics, 17(1), 72.

Hernandez-Ledezma JJ, Mathialagan N, Villanueva C, Sikes JD \& Roberts RM. (1993). Expression of bovine trophoblast interferons by in vitro-derived blastocysts is correlated with their morphological quality and stage of development. Molecular reproduction and development, 36(1), 1-6. 
Hidalgo C, Díez C, Duque P, Prendes JM, Rodríguez A, et al. (2005). Oocytes recovered from cows treated with retinol become unviable as blastocysts produced in vitro. Reproduction 129, 411-421.

Holm, P., Booth, P.J., Schmidt, M.H., et al., (1999). High bovine blastocyst development in a static in vitro production system using SOFaa medium supplemented with sodium citrate and myo-inositol with or without serum. Theriogenology 52, 683-700.

Holm P, Booth PJ, Callesen H. (2002). Kinetics of early in vitro development of bovine in vivo-and in vitro-derived zygotes produced and/or cultured in chemically defined or serum-containing media. Reproduction. 123:553-65.

Hon GC, Rajagopal N, Shen Y, McCleary DF, Yue F, Dang MD \& Ren B. (2013). Epigenetic memory at embryonic enhancers identified in DNA methylation maps from adult mouse tissues. Nature genetics, 45(10), 1198.

Hugentobler S, Morris DG, Kane MT, Sreenan JM. (2004) In situ oviduct and uterine $\mathrm{pH}$ in cattle. Theriogenology. 61:1419-1427.

Hunter JE, Tritz DE, Howell MO, DePriest PD, Gallion HH, et al. (1994). The prognostic and therapeutic implications of cytologic atypia in patients with endometrial hyperplasia. Gynecologic oncology, 55(1), 66-71.

Iwasaki S, Yoshiba N, Ushijima H, Watanabe S, Nakahara T. (1990). Morphology and proportion of inner cell mass of bovine blastocysts fertilized in vitro and in vivo. J Reprod Fertil, 90:279-284.

Jiang Z, Sun J, Dong H, Luo O, Zheng X, Obergfell C, et al. (2014). Transcriptional profiles of bovine in vivo pre-implantation development. BMC Genomics 15, 756.

Johnson $\mathrm{MH}$ \& Ziomek CA. (1981). The foundation of two distinct cell lineages within the mouse morula. Cell, 24(1), 71-80.

Kaidi S, Donnay I, Van Langendonckt A, Dessy F \& Massip A. (1998). Comparison of two co-culture systems to assess the survival of in vitro produced bovine blastocysts after vitrification. Animal reproduction science, 52(1), 39-50.

Kelley RL \& Gardner DK (2017). In vitro culture of individual mouse preimplantation embryos: the role of embryo density, microwells, oxygen, timing and conditioned media. Reproductive biomedicine online, 34(5), 441-454.

Kerns, K., Zigo, M., Drobnis, E. Z., Sutovsky, M., \& Sutovsky, P. (2018). Zinc ion flux during mammalian sperm capacitation. Nature Communications, 9, 2061. 
Kimura K, Spate LD, Green MP \& Roberts RM. (2005). Effects of D-glucose concentration, D-fructose and inhibitors of enzymes of the pentose phosphate pathway on the development and sex ratio of bovine blastocysts. Mol. Reprod. Dev. 72, 201-207.

Krisher RL \& Bavister BD. (1999). Enhanced glycolysis after maturation of bovine oocytes in vitro is associated with increased developmental competence. Mol. Reprod. Dev. 53:19-26

Kruip T, den Daas J.(1997). In vitro produced and cloned embryos: effects on pregnancy, parturition and offspring. Theriogenology 47:43-52.

Kubisch, H. M., Larson, M. A., \& Roberts, R. M. (1998). Relationship between age of blastocyst formation and interferon-т secretion by in vitroderived bovine embryos. Molecular Reproduction and Development: Incorporating Gamete Research, 49(3), 254-260.

Kubisch HM, Sirisathien S, Bosch P, Hernandez-Fonseca HJ, Clements G, Liukkonen JR, et al. (2004). Effects of developmental stage: embryonic interferon-tau secretion and recipient synchrony on pregnancy rate after transfer of in vitro produced bovine blastocysts. Reprod Domest Anim. 39(2):120-4.

Lane M, \& Gardner DK. (1992). Effect of incubation volume and embryo density on the development and viability of mouse embryos in vitro. Human reproduction, 7(4), 558-562.

Larson RC, Ignotz GG \& Currie WB. (1992). Transforming growth factor $\beta$ and basic fibroblast growth factor synergistically promote early bovine embryo development during the fourth cell cycle. Molecular reproduction and development, 33(4), 432-435.

Lavagi, I., Krebs, S., Simmet, K., Beck, A., Zakhartchenko, V., Wolf, E., \& Blum, H. (2018). Single-cell RNA sequencing reveals developmental heterogeneity of blastomeres during major genome activation in bovine embryos. Scientific reports, 8(1), 4071.

Lazzari G, Wrenzycki C, Herrmann D, Duchi R, Kruip T, Niemann H, et al. (2002). Cellular and molecular deviations in bovine in vitro produced embryos are related to the large offspring syndrome. Biol Reprod. 67:767-75.

Leese, H. J. (1988). The formation and function of oviduct fluid. Journal of reproduction and fertility, 82(2), 843-856.

Leroy J, Genicot G, Donnay I \& Van Soom A. (2005). Evaluation of the lipid content in bovine oocytes and embryos with nile red: a practical approach. Reproduction in domestic animals, 40(1), 76-78. 
Levy, R. R., Cordonier, H., Czyba, J. C., \& Guerin, J. F. (2001). Apoptosis in preimplantation mammalian embryo and genetics. Italian journal of anatomy and embryology.106 (2), 2:101-108.

Li CY, Zhao YH, Hao HS, Wang HY, Huang JM, et al. (2018). Resveratrol significantly improves the fertilisation capacity of bovine sex-sorted semen by inhibiting apoptosis and lipid peroxidation. Scientific Reports, $8,7603$.

Lim KT, Jang G, Ko KH, Lee WW, Park HJ, et al. (2007). Improved in vitro bovine embryo development and increased efficiency in producing viable calves using defined media. Theriogenology 67, 293-302.

Lindner GM \& Wright RW. (1983). Bovine embryo morphology and evaluation. Theriogenology 20(4):407-16.

Lonergan P, Rizos D, Gutierrez-Adan A, Moreira PM, Pintado B, et al. (2003a). Temporal divergence in the pattern of messenger RNA expression in bovine embryos cultured from the zygote to blastocyst stage in vitro or in vivo. Biol Reprod. 69:1424-1431.

Lonergan P, Rizos D, Gutierrez-Adan A, Fair T, Boland MP. (2003b). Effect of culture environment on embryo quality and gene expressionexperience from animal studies. Reprod Biomed Online; 7: 657-63.

Lonergan P, Fair T. (2014). The ART of studying early embryo development: progress and challenges in ruminant embryo culture. Theriogenology 81:49-55.

Lonergan P, Fair T, Forde N, Rizos D. (2016). Embryo development in dairy cattle. Theriogenology 86:270-277.

Loureiro B, Bonilla L, Block J, Fear JM, Bonilla AQ \& Hansen PJ. (2009). Colony-stimulating factor 2 (CSF-2) improves development and posttransfer survival of bovine embryos produced in vitro. Endocrinology. 150: 5046-5054.

Lowe R, Gemma C, Rakyan VK, Holland ML. (2015). Sexually dimorphic gene expression emerges with embryonic genome activation and is dynamic throughout development. BMC Genomics. 16:295.

Luciano, A. M., Franciosi, F., Modina, S. C., \& Lodde, V. (2011). Gap junctionmediated communications regulate chromatin remodeling during bovine oocyte growth and differentiation through cAMP-dependent mechanism (s). Biol Reprod, 85(6), 1252-1259.

Luciano AM, Sirard MA. (2018). Successful in vitro maturation of oocytes: a matter of follicular differentiation. Biol Reprod. 98(2):162-169. 
Majno G, Joris I. Apoptosis, oncosis, and necrosis. (1995). An overview of cell death. Am J Pathol 146:3-15.

Mamo S, Mehta JP, McGettigan P, Fair T, Spencer TE, Bazer FW \& Lonergan $P$. (2011). RNA sequencing reveals novel gene clusters in bovine conceptuses associated with maternal recognition of pregnancy and implantation. Biology of reproduction, 85(6), 1143-1151.

McKeegan PJ \& Sturmey RG (2011). The role of fatty acids in oocyte and early embryo development. Reproduction, Fertility and Development, 24(1), 59-67.

Macmillan KL, Taufa, KV, Day MA. (1997). Manipulating ovaries follicles wave patterns con partially synchronize returns to service and increase the pregnancy rate to second insemination. Proc $N Z$ Soc Anim Prod. $57: 210-237$.

Marco-Jiménez F, Jiménez-Trigos E, Almela-Miralles V \& Vicente JS. (2016). Development of cheaper embryo vitrification device using the minimum volume method. PLOS one, 11(2), e0148661.

Martínez, C. A., Nohalez, A., Parrilla, I., Motas, M., Roca, J., Romero, I. et al., (2017). The overlaying oil type influences in vitro embryo production: differences in composition and compound transfer into incubation medium between oils. Scientific Reports, 7, 10505.

Massip A, Mermillod P, Wils C \& Dessy F. (1993). Effects of dilution procedure and culture conditions after thawing on survival of frozen bovine blastocysts produced in vitro. Journal of reproduction and fertility, 97(1), 65-69.

Matwee $\mathrm{C}$, Betts $\mathrm{DH}$, King WA. Apoptosis in the early bovine embryo. Zygote 2000; 8:57-68.

Mee J.F. (2008). Prevalence and risk factors for dystocia in dairy cattle: A review. The Veterinary Journal. 176(1): 93-101.

Menezo, Y., \& Guerin, P. (1997). The mammalian oviduct: biochemistry and physiology. European Journal of Obstetrics and Gynecology and Reproductive Biology, 73(1), 99-104.

Mermillod P, Locatelli Y, Dalbies-Tran R, Uzbekova S, Baril G, Guignot F, Perreau C, Poulin N, Touze JL, Pennetier S, Schmaltz B, Cognie Y. (2006). In vitro production of ruminant embryos: results, limits and perspectives. Symposium COA/INRA Scientific Cooperation in Agriculture, 59-78.

Merton J.S., De Roos A.P., Mollaart E. et al. (2003). Factors affecting oocyte quality and quantity in commercial application of embryo technologies in the cattle breeding industry. Theriogenology 59:651-674 
McEvoy T, Sinclair K, Broadbent P, Goodhand K, Robinson J. (1998). Postnatal growth and development of Simmental calves derived from in vivo or in vitro embryos. Reprod Fertil Dev 10:459-464.

Mikkola M \& Taponen J. (2017). Embryo yield in dairy cattle after superovulation with Folltropin or Pluset. Theriogenology 88:84-88.

Moreno D, Neira A, Dubreil L, Liegeois L, Destrumelle S, Michaud S, et al. (2015). In vitro bovine embryo production in a synthetic medium: Embryo development, cryosurvival, and establishment of pregnancy. Theriogenology, 84(7), 1053-1060.

Morotti F, Sanches BV, Pontes JHF, Basso AC, Siqueira ER, Lisboa LA, Seneda MM. (2014). Pregnancy rate and birth rate of calves from a large scale IVF program using reverse-sorted semen in Bos indicus, Bos indicus-taurus, and Bos taurus cattle. Theriogenology 81:696-701.

Morton KM, Herrmann D, Sieg B, Struckmann C, Maxwell WMC, et al. (2007). Altered mRNA expression patterns in bovine blastocysts after fertilisation in vitro using flow-cytometrically sex-sorted sperm. Molecular reproduction and development, 74(8), 931-940.

Muñoz M, Corrales FJ, Caamaño JN, Díez C, Trigal B, Mora MI, Martín D, Carrocera S \& Gómez E. (2012). Proteome of the early embryo-maternal dialogue in the cattle uterus. Journal of Proteome Research. 11: 751-766.

Muñoz M, Uyar A, Correia E, Díez C, Fernández-González A, Caamaño JN, et al. (2014a). Prediction of pregnancy viability in bovine in vitro-produced embryos and recipient plasma with Fourier transform infrared spectroscopy. J Dairy Sci. 97(9):5497-507.

Muñoz M, Marquant-Le Guienne B, Fernandez-Gonzalez A, Díez C, Caamaño $\mathrm{JN}$, Trigal B, et al. (2014b). Metabolomic prediction of pregnancy viability in superovulated cattle embryos and recipients with fourier transform infrared spectroscopy. BioMed Res Int. 2014: 608579.

Muñoz M, Uyar A, Correia E, Díez C, Fernandez-Gonzalez A, Caamaño JN, et al. (2014c). Non-invasive assessment of embryonic sex in cattle by metabolic fingerprinting of in vitro culture medium. Metabolomics 10:443-51.

Muñoz M, Martin D, Carrocera S, Alonso-Guervos M, Mora Ml et al. (2017). Localisation of stem cell factor, stanniocalcin-1, connective tissue growth factor and heparin-binding epidermal growth factor in the bovine uterus at the time of blastocyst formation. Reproduction, Fertility and Development, 29(11), 2127-2139.

Mucci N, Aller J, Kaiser GG, Hozbor F, Cabodevila J, Alberio RH. (2006). Effect of estrous cow serum during bovine embryo culture on blastocyst 
development and cryotolerance after slow freezing or vitrification. Theriogenology 65:1551-62.

Neira JA, Tainturier D, Pena MA, Martal J. (2010). Effect of the association of IGF-I, IGF-II, bFGF, TGF- $\beta 1$, GM-CSF, and LIF on the development of bovine embryos produced in vitro. Theriogenology.73: 595-604.

Niemann H, Wrenzycki C (2000). Alterations of expression of developmentally important genes in preimplantation bovine embryos by in vitro culture conditions: implications for subsequent development. Theriogenology 53: 21-34.

Numabe T, Oikawa T, Kikuchi T, Horiuchi T. (2000). Birth weight and birth rate of heavy calves conceived by transfer of in vitro or in vivo produced bovine embryos. Anim Reprod Sci 64:13-20.

Nuttinck F., Jouneau A., Charpigny G., Hue I., Richard C., et al. (2017). Prosurvival effect of cumulus prostaglandin $\mathbf{G} / \mathrm{H}$ synthase 2/prostaglandin2 signaling on bovine blastocyst: impact on in vivo posthatching development. Biol Reprod, 96(3), 531-541.

O'Neill, C. (2008). The potential roles for embryotrophic ligands in preimplantation embryo development, Hum Reprod Update. 14(3): 275-88.

Orsi, N. M., \& Leese, H. J. (2004). Amino-acid metabolism of preimplantation bovine embryos cultured with bovine serum albumin or polyvinyl alcohol. Theriogenology 61, 561-572.

Paschoal DM, Sudano MJ, Schwarz KRL, Maziero RRD, Guastali MD, et al. (2017). Cell apoptosis and lipid content of in vitro-produced, vitrified bovine embryos treated with forskolin. Theriogenology, (87), 108-114.

Parrish J.J., Susko-Parrish J.L., Leibfried-Rutledge M.L., Critser E.S. Eyestone W.H. y First N. L. (1986). Bovine in vitro fertilization with frozen-thawed semen. Theriogenology, 25: (4), 591-600.

Parrish, J. J. (2014). Bovine in vitro fertilization: in vitro oocyte maturation and sperm capacitation with heparin. Theriogenology, 81(1), 67-73.

Pérez-Cerezales S, Ramos-lbeas P, Rizos D, Lonergan P, Bermejo-Alvarez, P \& Gutierrez-Adan A. (2017). Early sex-dependent differences in response to environmental stress. Reproduction, REP-17.

Perry G. (2016). IETS 2016. 2015 statistics of embryo collection and transfer in domestic farm animals. Embryo technology newsletter 34: 175

Peterson AJ \& Lee RF. (2003). Improving successful pregnancies after embryo transfer. Theriogenology, 59(2), 687-697. 
Pinyopummintr T \& Bavister BD. (1994). Development of bovine embryos in a cell-free medium: effects of type of serum, timing of its inclusion and heat inactivation. Theriogenology 41:1241-9.

Pontes JH, Nonato- Junior I, Sanches BV, Ereno-Junior JC, Uvo S, Barreiros TR, Oliveira JA, Hasler JF, Seneda MM. (2009). Comparison of embryo yield and pregnancy rate between in vivo and in vitro methods in the same Nelore (Bos indicus) donor cows. Theriogenology, 71:690-697

Pontes JH, Silva KC, Basso AC, Rigo AG, Ferreira CR, Santos GM, et al. (2010). Large-scale in vitro embryo production and pregnancy rates from Bos taurus, Bos indicus, and indicus-taurus dairy cows using sexed sperm. Theriogenology, 8(74), 1349-1355.

Prados, F. J., Debrock, S., Lemmen, J. G. \& Agerholm, I. (2012). The cleavage stage embryo. Hum. Reprod. 27 i50-i71.

Prather RS, Peters MS \& Van Winkle LJ. (1993). Alanine and leucine transport in unfertilized pig oocytes and early blastocysts. Molecular reproduction and development, 34(3), 250-254.

Puscheck EE, Awonuga AO, Yang Y, Jiang Z \& Rappolee DA (2015). Molecular biology of the stress response in the early embryo and its stem cells. In Cell Signaling During Mammalian Early Embryo Development (pp. 77-128). Springer, New York, NY.

Que, E.L., Bleher, R., Duncan, F.E., Kong, B.Y., Gleber, S.C., Vogt, S., \& Woodruff, T. K. (2015). Quantitative mapping of zinc fluxes in the mammalian egg reveals the origin of fertilization-induced zinc sparks. Nature chemistry, 7(2), 130.

Rall WF \& Fahy GM. (1985). Ice-free cryopreservation of mouse embryos at $-196^{\circ} \mathrm{C}$ by vitrification. Nature 313: 573-575.

Randi F, Fernandez-Fuertes B, McDonald M, Forde N, Kelly AK, et al. (2016). Asynchronous embryo transfer as a tool to understand embryo-uterine interaction in cattle: is a large conceptus a good thing? Reprod Fertil Dev. 28(12):1999-2006

Rasmussen S, Block J, Seidel GE, Brink Z, McSweeney K, et al. (2013). Pregnancy rates of lactating cows after transfer of in vitro produced embryos using X-sorted sperm. Theriogenology, 79(3), 453-461.

Reis A, Rooke JA, McCallum GJ, Staines ME, Ewen M, et al. (2003). Consequences of exposure to serum, with or without vitamin $E$ supplementation, in terms of the fatty acid content and viability of bovine blastocysts produced in vitro. Reproduction, Fertility and Development, 15(5), 275-284. 
Rizos D, Ward F, Boland MP and Lonergan P. (2001). Effect of culture system on the yield and quality of bovine blastocysts as assessed by survival after vitrification. Theriogenology 56 1-16.

Rizos D, Lonergan P, Boland MP, Arroyo-Garcia R, Pintado B, de la Fuente J, Gutierrez-Adan A. (2002a). Analysis of differential messenger RNA expression between bovine blastocysts produced in different culture systems: implications for blastocyst quality. Biol Reprod. 66:589-595.

Rizos D, Ward F, Duffy P, Boland MP \& Lonergan P, (2002b). Consequences of bovine oocyte maturation, fertilization or early embryo development in vitro versus in vivo: implications for blastocyst yield and blastocyst quality, Mol Reprod Dev, 61: (2), 234-48.

Rizos D, Gutierrez-Adan A, Perez-Garnelo S, De La Fuente J, Boland MP, Lonergan P. (2003). Bovine embryo culture in the presence or absence of serum: implication for blastocysts development, cryotolerance, and messenger RNA expression. Biol Reprod 68:236-43.

Rizos D, Clemente M, Bermejo-Alvarez P, de La Fuente J, Lonergan P, Gutiérrez-Adán A. (2008).Consequences of in vitro culture conditions on embryo development and quality. Reprod Domest Anim. 43(4): 44-50.

Robinson RS, Hammond AJ, Wathes DC, Hunter MG \& Mann GE. (2008). Corpus luteum-endometrium-embryo interactions in the dairy cow: underlying mechanisms and clinical relevance. Reproduction in Domestic Animals, 43(s2), 104-112.

Rodríguez A, Diez C, Ikeda S, Royo LJ, Caamaño JN, Alonso-Montes C, et al. Retinoids during the in vitro transition from bovine morula to blastocyst. Hum Reprod 2006; 21(8):2149-57.

Rodríguez A, Díez C, Caamaño JN, de Frutos C, Royo LJ, et al. (2007). Retinoid receptor-specific agonists regulate bovine in vitro early embryonic development, differentiation and expression of genes related to cell cycle arrest and apoptosis. Theriogenology 68, 1118-1127.

Rodriguez-Zas SL, Schellander K, Lewin HA. (2008). Biological interpretations of transcriptomic profiles in mammalian oocytes and embryos. Reproduction 135(2):129-139.

Rorie RW, Pool SH, Prichard JF, Betteridge KJ, Godke RA. (1994). A simplified procedure for making reconstituted blastocysts for interspecific and intergeneric transfer. Vet Rec. 135(8):186-7.

Ross PJ, Chitwood JL. (2012). Transcriptome analysis of single bovine embryos by Rna-Seq. Reprod Fertil Dev. 24(1):182. 
Saeki K, Hoshi M, Leibfried-Rutledge ML, First NL. (1991). In vitro fertilization and development of bovine oocytes matured in serum-free medium. Biol Reprod. 44:256-260.

Sakagami N, Umeki $H$, Nishino $O$, Uchiyama $H$, Ichikawa $K$, Takeshita $K$, Kaneko E, Akiyama K, Kobayashi S \& Tamada H. (2012). Normal calves produced after transfer of embryos cultured in a chemically defined medium supplemented with epidermal growth factor and insulin-like growth factor I following ovum pick up and in vitro fertilization in Japanese black cows. Journal of Reproduction and Development. 58: 140146.

Sanches BV, Marinho LSR, Pontes JHF, Basso AC, Meirinhos MLG, et al. (2013). Cryosurvival and pregnancy rates after exposure of IVF-derived Bos indicus embryos to forskolin before vitrification. Theriogenology, 80(4), 372377.

Sanches BV, Lunardelli PA, Tannura JH, Cardoso BL, Pereira MH, et al. (2016). A new direct transfer protocol for cryopreserved IVF embryos. Theriogenology 85:1147-1151.

Santos JEP, Thatcher WW, Chebel RC, Cerri RLA \& Galvao KN. (2004). The effect of embryonic death rates in cattle on the efficacy of estrus synchronization programs. Anim. Reprod. Sci. 82, 513-535.

Saragusty J \& Arav A. (2011). Current progress in oocyte and embryo cryopreservation by slow freezing and vitrification. Reproduction 141:119.

Sreenan JM \& Diskin MG. (1986). The extent and timing of embryonic mortality in the cow. In: J.M. Steenan and M.G. Diskin (Editors), Embryonic Mortality in Farm Animals. Martinus Nijhoff, Dordrecht, pp. 1-11.

Silke V, Diskin MG, Kenny DA, Boland MP, Dillon P, Mee JF \& Sreenan JM. (2001). Extent, pattern and factors associated with late embryonic loss in dairy cows. Anim. Reprod. Sci. 15, 1-12.

Siqueira LG, Torres CA, Souza ED, Monteiro PL Jr, Arashiro EK, Camargo LS, Fernandes CA, Viana JH. (2009). Pregnancy rates and corpus luteumrelated factors affecting pregnancy establishment in bovine recipients synchronized for fixed-time embryo transfer. Theriogenology, 72:949958

Siqueira LG, Dikmen S, Ortega MS, \& Hansen PJ. (2017). Postnatal phenotype of dairy cows is altered by in vitro embryo production using reverse X-sorted semen. Journal of dairy science, 100(7), 5899-5908.

Sinclair K. (1995). In vitro produced embryos as a means of achieving pregnancy and improving productivity in beef cows. Anim Sci J 60:5564. 
Sirard MA, Richard F, Blondin P, Robert C. (2006). Contribution of the oocyte to embryo quality. Theriogenology. 65:126-36.

Sirisathien S, Hernandez-Fonseca HJ, Bosch P, Hollet BR, Lott JD, \& Brackett BG. (2003). Effect of leukemia inhibitory factor on bovine embryos produced in vitro under chemically defined conditions. Theriogenology, 59(8), 1751-1763.

Spencer TE, Ott T.L., and Bazer F.W (1996). T-Interferon: Pregnancy Recognition Signal in Ruminants. Experimental Biology and Medicine. 213 (3):215 - 229

Spencer TE and Bazer FW (2004). Conceptus signals for establishment and maintenance of pregnancy. Reproductive Biology and Endocrinology 249.

Spencer TE, Johnson GA, Bazer FW, Burghardt RC \& Palmarini M (2007). Pregnancy recognition and conceptus implantation in domestic ruminants: roles of progesterone, interferons and endogenous retroviruses. Reproduction, Fertility, and Development1965-78.

Spencer, T. E., Sandra, O., \& Wolf, E. (2008). Genes involved in conceptusendometrial interactions in ruminants: insights from reductionism and thoughts on holistic approaches. Reproduction, 135(2), 165-179.

Sponchiado M, Gomes NS, Fontes PK, Martins T, del Collado M, et al. (2017). Pre-hatching embryo-dependent and -independent programming of endometrial function in cattle. PLOS ONE, 12(4), e0175954.

Stewart BM, Block J, Morelli P, Navarette AE, Amstalden M, Bonilla L, Hansen PJ, Bilby TR (2011). Efficacy of embryo transfer in lactating dairy cows during summer using fresh or vitrified embryos produced in vitro with sex-sorted semen. J Dairy Sci 94:3437-3445.

Stringfellow DA, Givens, MD. (2010). Manual of the International Embryo Transfer Society (IETS). 4th ed. Champaign, IL: IETS.

Sturmey, R. G., \& Leese, H. J. (2003). Energy metabolism in pig oocytes and early embryos. Reproduction, 126(2), 197-204.

Sturmey RG, Bermejo-Alvarez P, Gutierrez-Adan A, Rizos D, Leese HJ, and Lonergan P. (2010). Amino-acid metabolism of bovine blastocysts: a biomarker of sex and viability. Mol. Reprod. Dev. 77, 285-296.

Sutovsky, P. (2011). Sperm proteasome and fertilization. Reproduction, 142(1), 1-14.

Sudano MJ, Paschoal DM, Rascado TS, Magalhães LCO, Crocomo LF, LimaNeto JF, et al. (2011).Lipid content and apoptosis of in vitro-produced bovine embryos as determinants of susceptibility to vitrification. Theriogenology. 75:1211- 20. 
Sudano MJ, Paschoal DM, Silva Rascado T, Crocomo LF, Magalhães LC, Martins Junior $A$, et al. (2012). Crucial surviving aspects for vitrified in vitro-produced bovine embryos. Zygote; 11:1-8.

Summers MC, \& Biggers JD. (2003). Chemically defined media and the culture of mammalian preimplantation embryos: historical perspective and current issues. Human reproduction update, 9(6), 557-582.

Susko-Parrish J., Wheeler M., Ax R., First N. y Parrish J., (1990). The effect of penicillamine, hypotaurine, epinephrine and sodium metabisulfite on bovine in vitro fertilization, Theriogenology, 33: 333.

Suzuki K, Tatebe N, Kojima S, Hamano A, Orita M \& Yonezawa N. (2015). The Hinge Region of Bovine Zona Pellucida Glycoprotein ZP3 Is Involved in the Formation of the Sperm-Binding Active ZP3/ZP4 Complex. Biomolecules, 5(4), 3339-3353.

Tervit HR, Whittingham DG and Rowson LEA. (1972). Successful Culture in Vitro of Sheep and Cattle Ova. Journal of Reproduction and Fertility $\mathbf{3 0}$ 493-497.

Thibier M. (2005). The zootechnical applications of biotechnology in animal reproduction: current methods and perspectives. Reprod Nutr Dev 45(3): 235-42

Thompson JG, Sherman ANM, Allen NW, McGowan L T \& Tervit HR. (1998). Total protein content and protein synthesis within pre-elongation stage bovine embryos. Molecular Reproduction and Development: Incorporating Gamete Research, 50(2), 139-145.

Trigal B, Gómez E, Díez C, Caamaño JN, Martín D, Carrocera S and Muñoz M. (2011). In vitro development of bovine embryos cultured with activin $A$. Theriogenology 75 584-588.

Trigal B., Gómez E., Caamaño J. N., Muñoz M., Moreno J., Carrocera S., Martín D., Diez C. (2012). In vitro and in vivo quality of bovine embryos in vitro produced with sex-sorted sperm. Theriogenology. 78(7): 14651475.

Thouas GA, Korfiatis NA, French AJ, Jones GM \& Trounson AO. (2001). Simplified technique for differential staining of inner cell mass and trophectoderm cells of mouse and bovine blastocysts, Reprod Biomed Online, 3: (1), 25-29.

Ulbrich SE, Meyer SU, Zitta K, Hiendleder S, Sinowatz F, Bauersachs S,Büttner M, Fröhlich T, Arnold GJ, Reichenbach HD et al. (2011). Bovine endometrial metallopeptidases MMP14 and MMP2 and the metallopeptidase inhibitor TIMP2 participate in maternal preparation of pregnancy. Molecular and Cellular Endocrinology. 332: 48-57. 
Ulbrich S.E., Groebner A.E., Bauersachs S. (2013). Transcriptional profiling to address molecular determinants of endometrial receptivity--lessons from studies in livestock species. Methods. 59(1): 108-115.

Vajta G. and Kuwayama M. (2006). Improving cryopreservation systems. Theriogenology. 65(1): 236-244.

Vajta G, Rienzi L, Cobo A, Yovich J. (2010). Embryo culture: can we perform better than nature? Reprod Biomed Online 20:453-469

Van der Weijden VA, Chen S, Bauersachs S, Ulbrich SE, \& Schoen J. (2017). Gene expression of bovine embryos developing at the air-liquid interface on oviductal epithelial cells (ALI-BOEC). RB\&E 15: 91.

Van Soom A, Vanroose G, \& De Kruif A. (2001). Blastocyst evaluation by means of differential staining: a practical approach. Reproduction in Domestic Animals, 36(1), 29-35.

Van Soom A, Ysebaert MT \& de Kruif A. (1997). Relationship between timing of development, morula morphology, and cell allocation to inner cell mass and trophectoderm in in vitro-produced bovine embryos. Molecular Reproduction and Development: Incorporating Gamete Research, 47(1), 47-56.

Van Wagtendonk-de Leeuw AMJ, Mertonand AS, den Daas JHG. (1997). Pregnancy rates of IVP embryos. Proc. of the 13thScientific Meeting of the AETE, Lyon, France, p.212.

Van Wagtendonk-de Leeuw A, Aerts B, den Daas J. (1998). Abnormal offspring following in vitro production of bovine preimplantation embryos: a field study. Theriogenology 49:883-894.

Viana JHM, Figueiredo ACS, Siqueira LGB. (2017). Brazillian embryo industry in context: pitfalls, lessons, and expectations for the future. Animal Reproduction 14: 476-481.

Wale, P. L., \& Gardner, D. K. (2015). The effects of chemical and physical factors on mammalian embryo culture and their importance for the practice of assisted human reproduction. Human reproduction update, 22(1), 2-22.

Walsh SW, Williams EJ \& Evans ACO. (2011). A review of the causes of poor fertility in high milk producing dairy cows. Anim. Reprod.Sci.123, 127138.

Wang and Dey (2006). Roadmap to embryo implantation: clues from mouse models. Nat Rev Genet. 7:185-99 
Watson A.J. (2007). Oocyte cytoplasmic maturation: a key mediator of oocyte and embryo developmental competence. J Anim Sci. 85(13): E1E3.

Wiltbank MC, Baez GM, Garcia-Guerra A, Toledo MZ, Monteiro PL, Melo LF, Ochoa JC, Santos JE, Sartori R. (2016). Pivotal periods for pregnancy loss during the first trimester of gestation in lactating dairy cows. Theriogenology 86:239-253.

Wolf E, Arnold GJ, Bauersachs S., Beier, H. M., Blum, H., Einspanier, R., ... \& Prelle, K. (2003). Embryo-Maternal Communication in Bovine-Strategies for Deciphering a Complex Cross-Talk. Reproduction in Domestic Animals, 38(4), 276-289.

Wrenzycki C, Hermann D, Carnwath JW, Niemann H. (1996). Expression of the gap junction gene connexin43 (Cx43) in preimplantation bovine embryos derived in vitro or in vivo. J Reprod Fertil 108:17-24.

Wrenzycki C, Wells D, Herrmann D, Miller A, Oliver J, Tervit R Niemann H. (2001). Nuclear transfer protocol affects messenger RNA expression patterns in cloned bovine blastocysts. Biology of Reproduction, 65(1), 309-317.

Wrenzycki C, Lucas-Hahn A, Herrmann D, Lemme E, Korsawe K and Niemann H. (2002). In Vitro Production and Nuclear Transfer Affect Dosage Compensation of the X-Linked Gene Transcripts G6PD, PGK, and Xist in Preimplantation Bovine Embryos. Biology of Reproduction 66 127-134.

Wrenzycki C, Herrmann D, Lucas-Hahn A, Korsawe K, Lemme E, Niemann H. (2005). Messenger RNA expression patterns in bovine embryos derived from in vitro procedures and their implications for development. Reprod Fertil Dev, 17:23-35.

Wrenzycki C. (2016). In vitro culture systems: how far are we from optimal conditions?. Anim. Reprod, 13(3), 279-282.

Young LE, Sinclair KD, Wilmut I. (1998). Large offspring syndrome in cattle and sheep. Reviews of Reproduction. 3:155-163

Zhang, N., Duncan, F. E., Que, E. L., O'Halloran, T. V. \& Woodruff, T. K. (2016). The fertilization-induced zinc spark is a novel biomarker of mouse embryo quality and early development. Sci. Rep. 6, 22772. 


\section{2 | OBJETIVOS DE LA TESIS}

A. Murillo-Ríos

Centro de Biotecnología Animal, Servicio Regional de Investigación y Desarrollo

Agroalimentario (SERIDA), Gijón, 33394 
El objetivo general de esta tesis es desarrollar un sistema de cultivo para mejorar la calidad y la viabilidad de embriones bovinos producidos in vitro. Con este propósito, los objetivos específicos del presente trabajo fueron los siguientes:

1- Analizar, a corto y a largo plazo, los efectos que provoca la privación de proteína en cultivo individual durante la formación del blastocisto bovino in vitro. A tal fin, se evaluaron parámetros de desarrollo y viabilidad embrionaria, parámetros de gestación y fenotipos de los individuos nacidos (Capítulo 1).

2- Estudiar cómo la falta de proteína en cultivo, los estadíos embrionarios, el sexo del embrión, el contenido de lípidos y el proceso de vitrificación influyen en los fenotipos de embriones y terneros (Capítulo 2).

3- Establecer si una concentración muy reducida de suero fetal bovino $(0.1 \%)$ en cultivo desde el día 1 hasta el día 6 puede mejorar los porcentajes de blastocistos tempranos, sin perjuicio de la calidad del embrión, determinada como supervivencia a la criopreservación, contenido de lípidos, apoptosis y viabilidad de la gestación de los embriones producidos (Capítulo 3).

4- Cuantificar el HDGF total presente en el fluido uterino mediante Multiple Reaction Monitoring (MRM), e identificar los efectos de HDGF recombinante en el desarrollo de estadíos embrionarios específicos de 
embriones cultivados in vitro. Y evaluar la viabilidad de la gestación con los embriones producidos y los fenotipos de los terneros al parto. También se analizó el dimorfismo en la expresión de HDGF en células endometriales cocultivadas con un embrión macho o un embrión hembra (Capítulo 4). 


\title{
3 | CAPítulo I
}

\section{Short- and long-term outcomes of the absence of protein during bovine blastocyst formation in vitro}

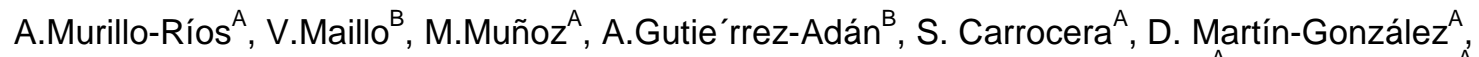 \\ A. Fernandez-Buznego ${ }^{A}$ and E. Gómez ${ }^{A}$ \\ ${ }^{A}$ Genética y Reproducción Animal, Centro de Biotecnología Animal, SERIDA, Camino de Rioseco \\ 1225, 33394 Gijón, Spain. \\ BDepartamento de Reproducción Animal, INIA, Ctra de la Coruña, km 5.9, 2804 Madrid, Spain.
}

Reproduction, Fertility and Development. 2017, 29(6), 1064-1073

This work was supported by the Spanish Ministry of Economy and Competitiveness - MINECOproject AGL2012-37772 and AGL2012-39652, Principado de Asturias, Plan de Ciencia, Tecnología e Innovación 2013-2017 (GRUPIN 14-114) and FEDER and by the European Union Seventh Framework Program (FP7/2007-2013) under the grant agreement n8311776. M. M. was supported by MICINN-RYC08-03454. A. M. was supported by Secretaría Nacional de Educación Superior, Ciencia, Tecnología e Innovación - Ecuador - II Fase 2013. The authors are members of the COST Action FA1201 Epiconcept: Epigenetics and Periconception environment. 


\section{Abstract}

In cattle, individual in vitro embryo culture after Day 6 benefits development, allowing non-invasive analysis of culture medium. However, undefined supplements in culture reduce analytical reliability. In this study we assayed the short- and long-term performance of embryos after bovine serum albumin removal over a 24-h period in individual culture.

The absence of protein decreased embryo development and cell counts in the inner cell mass without affecting blastocyst sex ratio. However, the absence of protein produced embryos with an improved tendency to survive vitrification after $24 \mathrm{~h}$ in culture $(P=0.07)$. After transfer to recipients, birth rates of embryos that had been cultured with protein tended to decrease $(P<0.06)$ mostly as a result of a higher number of miscarriages $(P<0.013)$, reflecting lower viability. Birthweight, gestation length, height and thorax circumference did not differ between embryos cultured with or without protein. In fresh blastocysts cultured without protein, gene expression analysis showed higher abundance $(P, 0.05)$ of insulin-like growth factor 2 receptor (IGF2R; imprinting) and activating transcription factor 4 (ATF4) and DNA-damage inducible transcript 3 (DDIT3; endoplasmic reticulum stress) transcripts, with DNA methyltransferase 3A (DNMT3A; imprinting) tending to increase $(P=0.062)$. However, in hatched blastocysts that survived cryopreservation, glucose-6-phosphate dehydrogenase (G6PD) was overexpressed in embryos cultured without protein $(P<0.01)$. The absence of protein results in fewer blastocysts but improved longterm viability after cryopreservation. 


\subsection{Introduction}

Within the culture of most cell types, bovine serum albumin (BSA) is not essential but it frequently improves performance (Francis 2010). In embryo technologies, BSA has been a classical alternative to serum and co-cultures (Duque et al. 2003), improving survival of cryopreservation with intact (Gómez et al. 2008a) and biopsied embryos (Yotsushima et al. 2004). Beneficial effects are observed preferentially in long-term culture, where the absence of protein is clearly detrimental (Krisher et al. 1999; Duque et al. 2003; Orsi and Leese 2004). BSA preparations are widely used in cell cultures of different species and obviously in bovine embryo culture. The embryo incorporates exogenous protein from the culture medium $(\mathrm{CM})$ by endocytosis in order to maintain the intracellular amino-acid pool (Thompson et al. 1998). However, BSA is not a defined protein compound because it carries lipids, amino acids, hormones, peptides, metals and other undefined low-molecular-weight molecules that determine a significant batch-to-batch variation (reviewed by Francis 2010).

In replacing albumin, probably the most used macromolecular supplementation is the non-metabolisable substitute polyvinyl-alcohol (PVA). In cattle, PVA has been used as a unique macromolecule during in vitro maturation (IVM) and in vitro culture (IVC; Duque et al. 2003; Gómez et al. 2003, 2004; Orsi and Leese 2004; Lim et al. 2007), resulting in both pregnancies and births (Hidalgo et al. 2003, 2005; Lim et al. 2007).

In cattle, entire in vitro development in simple medium and individual culture negatively affects developmental competence, embryo quality and survival of cryopreservation, with few authors reporting improvements of blastocyst development in long-term individual culture compared with group culture 
(Goovaerts et al. 2010). To overcome negative effects of entire individual culture we used group-cultured embryos from Day-1 to Day-6 and a shorter in vitro individual culture step of 24 h (Muñoz et al. 2014a) starting from Day-6 morulae (90\%) and early blastocysts. The CM used in our predictive work was synthetic oviduct fluid with amino acids and myo-inositol, modified with $6 \mathrm{~g} \mathrm{~L}^{-1}$ bovine serum albumin (SOFaaci-BSA; Rodríguez et al. 2007). Removal of BSA from SOFaaci results in a chemically defined embryo culture medium. Defined conditions will help in avoiding sanitary concerns, in normalising culture conditions and in facilitating reliable analysis of media. In addition, BSA withdrawal will enhance the commercial interest of non-invasive analytical techniques in culture media, because repeatability will increase and interlaboratory comparisons will become possible.

In this study we analysed the effects of protein removal on blastocyst development in individual culture with respect to survival of cryopreservation, differential cell counts (as a primary test of embryonic quality), pregnancy rate (embryonic viability), gestation length and weight and morphometry of individuals born (long-term embryonic quality). According to the observed results and the protein restriction hypothesis, we selected and analysed the expression of a panel of candidate genes related to metabolism, endoplasmic reticulum (ER), oxidative stress and imprinting mechanisms, factors which may underlie the observed effects. To our knowledge, no other work has analysed the same developmental period in individual culture and defined conditions. 


\subsection{Materials and Methods}

All experimental procedures were sanctioned by the Animal Research Ethics Committee of SERIDA (Agreement 02/02/2012) in accordance with the European Community Directive 86/609/EC. Ovaries were collected from cows that were slaughtered in commercial abattoirs (Matadero de León, León, Spain, mostly for Holstein cows; Matadero de Tineo, Tineo, for Asturiana de los Valles (AV) cows) and transported to the laboratory in $9 \mathrm{mg} \mathrm{mL}^{-1} \mathrm{NaCl}$ solution with antibiotics. All reagents were purchased from SIGMA (Madrid, Spain) unless otherwise stated.

\subsubsection{In vitro embryo production}

Ovarian follicles (3-8mm in diameter) were aspirated and oocytes enclosed in a compact cumulus ( $\geq 3$ cell layers) with evenly granulated cytoplasm were selected for in vitro maturation as described previously (Gómez et al. 2008b). Briefly, the cumulus-oocyte complexes (COCs) were washed in TCM-199HEPES and matured in bicarbonate-buffered TCM 199 with FSH, LH, 17boestradiol and $10 \%$ fetal calf serum. Approximately 50 COCs were cultured in $500 \mathrm{~mL}$ maturation medium in four-well dishes at $39^{\circ} \mathrm{C}$ in $5 \% \mathrm{CO}_{2}$ in air with high humidity for 22-24 h. After IVM, oocytes were subjected to in vitro fertilization (IVF; Day 0) with frozen-thawed, sex-sorted or non-sex-sorted spermatozoa from Holstein and AV bulls following described procedures (Trigal et al. 2012a and Gómez et al. 2008b, respectively). Briefly, semen samples from sex-sorted bulls were layered on a Percoll gradient (90\% and 45\%). After centrifugation the pellet was washed with Fert-TALP containing heparin and penicillamine, hypotaurine and epinephrine (PHE), centrifuged once more and the resultant 
pellet was used for fertilisation. For non-sex-sorted spermatozoa, sperm separation was performed using the swim-up technique. Semen was layered down to a tube containing pre-equilibrated Sperm-TALP and the upper layer with motile spermatozoa collected after a 1-h incubation. The concentration of spermatozoa was determined with a haemocytometer. The COCs were washed and placed in four well culture dishes containing pre-equilibrated fertilization medium (Fert-TALP) with heparin (non-sex-sorted spermatozoa) or with heparin+PHE (sex-sorted spermatozoa). In vitro fertilisation was accomplished by incubating oocytes and spermatozoa together for $18-20 \mathrm{~h}$ at $39^{\circ} \mathrm{C}$ in $5 \%$ $\mathrm{CO} 2$ with high humidity. For experiments entirely in vitro, IVF was performed with non-sorted spermatozoa ( $n=6$ bulls), while embryos for transfer to recipients were produced with a combination of non-sorted and sex-sorted spermatozoa ( $n=6$ and $n=4$ bulls, respectively). The embryo culture medium was synthetic oviduct fluid (SOF) containing essential and non-essential amino acids, citrate, myo-inositol and modified with or without $6 \mathrm{mg} \mathrm{mL}^{-1}$ BSA. Polyvinyl alcohol (PVA; $0.5 \mathrm{mg} \mathrm{mL}^{-1}$ ) was added as a BSA replacement. Presumptive zygotes were cultured in groups in $50-\mathrm{mL}$ droplets under mineral oil; $1-2 \mathrm{~mL}$ per embryo; $25-35$ embryos per drop; $5 \% \mathrm{CO}_{2}, 5 \% \mathrm{O}_{2}$ in saturated humidity. Subsequently, Day-6 morulae (90\% approximately) and early blastocysts ( $10 \%$ approximately) were picked up and individually transferred to individual culture drops (12 mL) for $48 \mathrm{~h}$ (Day-6 to Day-8; individual culture) of either SOF $+6 \mathrm{mgmL}^{-1} \mathrm{BSA}$ or SOF $+0.5 \mathrm{mgmL}^{-1} \mathrm{PVA}$. Media were renewed on Day-3 and Day-6. Blastocyst development, expansion and hatching rates were analysed on Day-7 and Day-8. 


\subsubsection{Differential cell counts}

Cell counts were taken in Day-8 expanded blastocysts. Embryonic cells in the inner cell mass (ICM) and trophectoderm (TE) were differentially counted using a propidium iodide-bisbenzimide method (Trigal et al. 2012a). Briefly, blastocysts were incubated in BSA-free TCM-199-HEPES with 1\% Triton X-100 and propidium iodide for $30 \mathrm{~s}$. Samples were fixed in ethanol with bisbenzimide (Hoechst 33342 ), stored overnight at $4^{\circ} \mathrm{C}$ and then transferred directly to a glycerol droplet on a glass microscope slide. Cell counts were made using digital images obtained with an inverted microscope equipped with an ultraviolet excitation filter at 330-385 $\mathrm{nm}$ and a barrier filter at $420 \mathrm{~nm}$ (Olympus Spain). The TE cells were identified by their red fluorescence, whereas ICM cells appeared blue.

\subsubsection{Vitrification of embryos}

Vitrification procedures have been previously described in detail (Trigal et al. 2012a). Briefly, Day-7 and Day-8 excellent and very good expanding to expanded in vitro-produced (IVP) blastocysts were vitrified in two steps using fibre plugs (Cryo-Logic vitrification method (CVM); Cryologic, Australia). Vitrification solutions contained ethylene glycol, dimethyl sulfoxide (DMSO) and sucrose as described (Vajta et al. 1998). Samples were vitrified by touching with the hook in a supercooled block placed in liquid nitrogen. Embryos were warmed in one step (Caamaño et al. 2015) by directly immersing the fibre plug end in $0.25 \mathrm{M}$ sucrose, where the embryo was kept for $5 \mathrm{~min}$. Prior to transfer, vitrified-warmed embryos were allowed to re-expand for $1-2 \mathrm{~h}$ in vitro. Subsequently, re-expanded embryos were washed twice and loaded in straws. 


\subsubsection{Warming and survival of vitrified embryos}

In vitro survival rates were analysed after warming and subsequent in vitro culture of Day-7 and Day-8 vitrified embryos in SOF $+10 \%$ FCS for $48 \mathrm{~h}$.

\subsubsection{Oestrus synchronisation of recipients, embryo transfer and pregnancy and birth monitoring}

Detailed procedures have been previously described (Hidalgo et al. 2004). Briefly, Holstein and Asturiana de los Valles heifers were synchronised in oestrus by using an intravaginal progestagen device (PRID Alpha) for 10 days combined with a prostaglandin $\mathrm{F}_{2} \alpha(\mathrm{PG})$ analogue (Dynolitic; Pfizer, Madrid, Spain) injected $48 \mathrm{~h}$ before progestagen removal. Normally, cryopreserved Day7 embryos show higher pregnancy rates than older embryos (Hasler 2000) and this led us to set up an embryo transfer study using only Day-7 vitrified embryos. On Day 7, single re-expanded, vitrified and warmed blastocysts were non-surgically transferred to recipients in the cranial third of the uterine horn ipsilateral to the corpus luteum (CL) under epidural anaesthesia. Pregnancy was diagnosed on Day 40 and on Day 62; miscarriages and birth rates were monitored in recipients transferred once or twice. However, bodyweight (BW), height at withers $(\mathrm{HW})$, thorax circumference (TC), gestation length $(\mathrm{GL})$ and daily weight (BW/GL), were recorded at birth in recipients transferred up to four times.

3.2.6. Gene expression analysis: RNA extraction, reverse transcription and quantification of mRNA transcript abundance 
For gene expression studies, Day-7 embryos were analysed both before and after vitrification. Pools of $n=10$ Day- 7 expanded blastocysts were collected fresh and pools of $n=6$ vitrified blastocysts were collected after hatching at $24 \mathrm{~h}$ in postwarming culture. Poly(A) RNA was extracted using the Dynabeads mRNA DIRECT Micro Kit (Ambion; Thermo Fisher Scientific Inc., Oslo, Norway) following the manufacturer's instructions and with minor modifications (BermejoÁlvarez et al. 2008). After 10 min incubation in lysis buffer with Dynabeads, poly $(\mathrm{A}) \mathrm{RNA}$ attached to the Dynabeads was extracted with a magnet and washed twice with Washing Buffer A and Washing Buffer B. Next, RNA was eluted with Tris-HCl. Immediately after extraction, the reverse transcription (RT) reaction was carried out following the manufacturer's instructions (Epicentre Technologies Corp., Madison, WI, USA) using poly(T) primers, random primers and Moloney Murine Leukemia Virus (MMLV) high performance reverse transcriptase enzyme in a total volume of $40 \mathrm{~mL}$ to prime the RT reaction and to produce $\mathrm{cDNA}$. Tubes were heated to $70^{\circ} \mathrm{C}$ for $5 \mathrm{~min}$ to denature the secondary RNA structure and then the RT mix was completed with the addition of 50 units of reverse transcriptase. They were then incubated at $25^{\circ} \mathrm{C}$ for $10 \mathrm{~min}$ to favour the annealing of random primers, followed by $37^{\circ} \mathrm{C} 60 \mathrm{~min}$ to allow $\mathrm{RT}$ of RNA and finally $858 \mathrm{C}$ for $5 \mathrm{~min}$ to denature the enzyme. All primers were designed using Primer-BLAST software (http://www.ncbi.nlm.nih.gov/tools/primer-blast/, verified 29 February 2016) to span exon-exon boundaries when possible.

All quantitative polymerase chain reactions (qPCR) were carried out in duplicate on the Rotorgene 6000 Real-Time Cycler TM (Corbett Research, Sydney, Australia) by adding a 2-mL aliquot of each sample to the PCR mix (GoTaq qPCR Master Mix; Promega Corporation, Madison, WI, USA) containing the 
specific primers selected to amplify glyceraldehyde-3-phosphate dehydrogenase $(G A P D H)$, solute carrier family 2 (facilitated glucose transporter) member 1 (SCL2A1, formerly GLUT1), glucose-6-phosphate dehydrogenase $(G 6 P D)$, glutathione peroxidase 1 (GPX1), superoxide dismutase 2, mitochondrial (SOD2, formerly MnSOD), DNA methyltransferase 3A (DNMT3A), insulin-like growth factor 2 receptor (IGF2R), beclin 1, autophagy related (BECN1), transmembrane BAX inhibitor motif-containing 6 (TMBIM6), activating transcription factor 4 (ATF4) and DNA-damage-inducible transcript 3 (DDIT3). Primer sequences and the approximate sizes of the amplified fragments of all transcripts are shown in Table 3.1. Cycling conditions were $94^{\circ} \mathrm{C}$ for 3 min followed by 35 cycles of $94^{\circ} \mathrm{C}$ for $15 \mathrm{~s}, 56^{\circ} \mathrm{C}$ for $30 \mathrm{~s}, 72^{\circ} \mathrm{C}$ for $10 \mathrm{~s}$ and $10 \mathrm{~s}$ of fluorescence acquisition. Each pair of primers was tested to achieve efficiencies close to 1 and then the comparative cycle threshold (DDCT) method was used to quantify expression levels as described by Schmittgen and Livak (2008). To avoid primer dimer artefacts, fluorescence was acquired in each cycle at a temperature higher than the melting temperature of primer dimers (specific for each product, $80-86^{\circ} \mathrm{C}$ ). Then the threshold cycle or the cycle during the log-linear phase of the reaction at which fluorescence increased above background was determined for each sample. The DCT value was determined by subtracting the endogenous control (an average of $\mathrm{H} 2 \mathrm{~A}$ Histone Family, Member Z (H2AZ) and actin, beta $(A C T B))$ CT value for each sample from each gene CT value of the sample. Calculation of DDCT involved using the highest sample DCT value (i.e. the sample with the lowest target expression) as a constant to subtract from all other DCT sample values. Fold- 
changes in the relative gene expression of the target were determined using the equation 2-DDCT.

Table 3.1. Details of primers used for $q P C R$

\begin{tabular}{|c|c|c|c|c|c|}
\hline $\begin{array}{l}\text { Entrez } \\
\text { gene } \\
\text { symbol }\end{array}$ & Gene name & $\begin{array}{l}\text { Accession } \\
\text { number }\end{array}$ & $\begin{array}{l}\text { Forward } \\
\text { primer }\left(5^{\prime}-3^{\prime}\right)\end{array}$ & $\begin{array}{l}\text { Reverse } \\
\text { primer }\left(5^{\prime}-3^{\prime}\right)\end{array}$ & $\begin{array}{l}\text { Product } \\
\text { length } \\
\text { (bp) }\end{array}$ \\
\hline$H 2 A F Z$ & $\mathrm{H} 2 \mathrm{~A}$ histone family, member $\mathrm{Z}$ & NM_174809 & AGGACGACTAGCCATGGACGTGTG & CCACCACCAGCAATTGTAGCCTTG & 209 \\
\hline GAPDH & $\begin{array}{l}\text { Glyceraldehyde-3-phosphate } \\
\text { dehydrogenase }\end{array}$ & NM_001034034.2 & ACCCAGAAGACTGTGGATGG & ATGCCTGCTTCACCACCTTC & 247 \\
\hline$S C L 2 A I$ & $\begin{array}{l}\text { Solute carrier family } 2 \text { (facilitated } \\
\text { glucose transporter) member } 1\end{array}$ & NM_174602.2 & CTGATCCTGGGTCGCTTCAT & ACGTACATGGGCACAAAACCA & 68 \\
\hline$G 6 P D$ & Glucose-6-phosphate dehydrogenase & NM_001244135.1 & CGCTGGGACGGGGTGCCCTTCATC & CGCCAGGCCTCCCGCAGTTCATCA & 347 \\
\hline$G P X I$ & Glutathione peroxidase 1 & NM_174076.3 & GCAACCAGTTTGGGCATCA & CTCGCACTTTTCGAAGAGCATA & 116 \\
\hline SOD2 & $\begin{array}{l}\text { Superoxide dismutase 2, mitochondrial } \\
\text { (formerly MnSOD) }\end{array}$ & S67818.1 & GCTTACAGATTGCTGCTTGT & AAGGTAATAAGCATGCTCCC & 101 \\
\hline DNMT3A & DNA methyltransferase $3 \mathrm{~A}$ & AY271299 & CTGGTGCTGAAGGACTTGGGC & CAGAAGAAGGGGCGGTCATC & 318 \\
\hline$I G F 2 R$ & Insulin-like growth factor 2 receptor & NM_174352.2 & GCTGCAGTGTGCCAAGTGAAAAAG & AGCCCCTCTGCCATTGTTACCT & 201 \\
\hline BECNI & Beclin 1, autophagy related & NM_001033627.2 & GATTCTGGACCGTGTCACCAT & TGTGGACATCATCCTGGCTGG & 166 \\
\hline TMBIM6 & $\begin{array}{l}\text { Transmembrane } \mathrm{BAX} \text { inhibitor } \\
\text { motif-containing } 6\end{array}$ & NM_001076414.1 & GCTTTGGCTGTTCACAGAGC & TACGGTGATGTGGTACGCTG & 150 \\
\hline ATF4 & Activating transcription factor 4 & NM_001034342.2 & CCGAGATGAGCTTTCTGAGC & AGCATCCTCCTTGCTGTTGT & 223 \\
\hline DDIT3 & DNA-damage-inducible transcript 3 & NM_001078163.1 & GTCACTGCCTTTCTCCTTCG & GGGAGGTGTGTGTGACCTCT & 217 \\
\hline
\end{tabular}

\subsubsection{Embryo sexing by PCR}

The results of the gene expression study provided possible evidence that protein removal altered the embryonic sex ratio. Accordingly, the embryonic sex was determined in expanded blastocysts produced with and without protein by a built-in control PCR technique based on amelogenin amplification (Trigal et al. $2012 b$ ). This method is particularly appropriate when a fully accurate embryonic sex diagnosis is necessary.

\subsubsection{Statistical analysis}

Data from embryo development, cell counts and survival of vitrification and pregnancy, calving and miscarriage rates were analysed using the Proc GLM module of SAS/STAT (Version 9.2; SAS Institute Inc., Cary, NC, USA). The models included the following fixed effects: culture system, replicate, bull, bull and recipient breeds, as well as year and season for pregnancy and calving 
rates. Birthweight, gestation length and various body measurements (height and thorax circumference) also included embryonic sex as a fixed effect. Leastsquares mean (LSM) and their erros ( \pm s.e.m.) were estimated for each level of fixed effects with a significant F-value. The Ryan-Einot-Gabriel-Welsch Q-test was used to compare the raw means of the levels from the fixed effects. For gene expression, data were analysed using the Sigma Stat (Jandel Scientific, San Rafael, CA, USA) software package. Student's $t$-test was performed to study the differences in expression values between fresh embryos cultured with or without protein and between vitrified embryos cultured with or without protein.

\subsection{Results}

\subsubsection{Embryo development}

Under the culture conditions assayed, embryos cleaved at $\sim 85 \%$ on Day 3 and produced $40-55 \%$ morulae on Day 6. In vitro development of bovine Day-6 embryos cultured individually with BSA led to blastocyst rates superior to those without BSA (Table 3.2). On Day 7, the presence of protein led to increased proportions of blastocysts $(P<0.0001)$ and the expansion rates tended to increase $(P=0.054)$. On Day 8 , blastocysts and expansion rates were significantly higher with protein $(P<0.05$ and $P<0.01$, respectively) than without. Hatching rates in vitro were not affected at any time point. The presence of protein did not lead to obvious microscopic differences in blastocyst morphology. 
Table 3.2. In vitro development of Day-6 embryos produced in group culture with SOFaaci with BSA $\left(6 \mathrm{~g} \mathrm{~L}^{-1}\right)$ and subsequently cultured individually in $12-\mu \mathrm{L}$ drops of SOFaaci with protein (6mg mL $\mathrm{mSA}^{-1}$ ) or without protein $\left(0.5 \mathrm{mg} \mathrm{mL}^{-1} \mathrm{PVA}\right)$ up to Day 8.

\begin{tabular}{|c|c|c|c|c|c|c|}
\hline \multirow[b]{2}{*}{ Protein } & \multirow[b]{2}{*}{$n$} & \multicolumn{2}{|c|}{ Day 7 (\%) } & \multicolumn{3}{|c|}{ Day 8 (\%) } \\
\hline & & Blastocysts & Expanded & Blastocysts & Expanded & Hatched \\
\hline$(+)$ & 618 & $71.3 \pm 2.7^{x}$ & $46.6 \pm 3.1$ & $80.6 \pm 2.9^{a}$ & $66.4 \pm 3.3^{x}$ & $7.1 \pm 1.7$ \\
\hline$(-)$ & 733 & $51.6 \pm 2.7^{y}$ & $38.4 \pm 3.0$ & $71.7 \pm 2.8^{\mathrm{b}}$ & $54.3 \pm 3.3^{y}$ & $4.0 \pm 1.7$ \\
\hline$P<$ & & 0.0001 & 0.054 & 0.043 & 0.0079 & 0.17 \\
\hline
\end{tabular}

\subsubsection{Differential cell counts}

The absence of protein decreased cell counts in the ICM $(P<0.05)$ and no other analysed variable was affected (i.e. TE, total cells and ICM/total cell rate; Table 3.3).

Table 3.3. Differential cell counts in Day-8 expanded blastocysts cultured individually from Day 6 to Day 8 in drops of SOFaaci with protein $\left(6 \mathrm{mg} \mathrm{mL}^{-1}\right.$ BSA) or without protein (0.5 mg mL $\mathrm{mVA}^{-1}$ )

\begin{tabular}{cccccc}
\hline Protein & $\boldsymbol{n}$ & ICM & TE & Total & ICM/TOTAL \\
\hline$(+)$ & 44 & $32.3 \pm 1.2^{\mathrm{a}}$ & $106.9 \pm 8.0$ & $115.3 \pm 4.4$ & $23.6 \pm 2.0$ \\
$(-)$ & 34 & $25.4 \pm 1.7^{\mathrm{b}}$ & $102.3 \pm 6.0$ & $122.8 \pm 4.9$ & $20.7 \pm 1.5$ \\
\hline
\end{tabular}

Data from four replicates. Data are LSM of replicates \pm s.e.m.

ICM, inner cell mass; TE, trophectoderm.

${ }_{a, b}$ Values within columns with different superscript letters differ significantly $\mathrm{P}<0.05$

\subsubsection{In vitro survival of vitrification and warming}

After warming, a trend was observed in increased survival rates of vitrified embryos cultured in medium deprived of protein at $2 \mathrm{~h}$ and $24 \mathrm{~h}(P=0.09$ and $P=0.07$, respectively; not shown in tables). In contrast, hatching rates at $24 \mathrm{~h}$ for

Day-7 embryos cultured without protein were higher $(P<0.03)$ than all Day-8 embryos produced with or without protein (Table 3.4). This was not observed with Day-7 embryos produced with BSA, which did not differ from their Day-8 counterparts. Differences between treatments observed with expansion and hatching at $2 \mathrm{~h}$ and $24 \mathrm{~h}$ were all suppressed $48 \mathrm{~h}$ after warming. Almost all 
embryos (138/139) cultured without protein and vitrified on Day 7 re-expanded 2 h after warming.

Table 3.4. In vitro survival after vitrification and warming of Day-7 and Day-8 bovine expanded blastocysts that were cultured individually in synthetic oviduct fluid (SOF) medium with protein $\left(6 \mathrm{mg} \mathrm{mL}^{-1}\right.$ BSA) or without protein $\left(0.5 \mathrm{mg} \mathrm{mL}^{-1}\right.$ PVA) from Day 6 onwards.

\begin{tabular}{|c|c|c|c|c|c|c|}
\hline \multirow{2}{*}{$\begin{array}{l}\text { Protein } \\
\text { as of } \\
\text { Day- } 6\end{array}$} & \multirow{2}{*}{$\begin{array}{c}\text { Vitrification } \\
\text { Day }\end{array}$} & \multirow[b]{2}{*}{$n$} & \multicolumn{2}{|c|}{ Re-expansion (\%) } & \multicolumn{2}{|c|}{ Hatching (\%) } \\
\hline & & & $2 \mathrm{~h}$ & $24 \mathrm{~h}$ & $24 h$ & $48 \mathrm{~h}$ \\
\hline$(+)$ & 7 & 144 & $95.0 \pm 1.9$ & $93.6 \pm 2.2$ & $35.0 \pm 6.3^{\mathrm{ab}}$ & $71.8 \pm 5.6$ \\
\hline$(-)$ & 7 & 139 & $99.4 \pm 1.9$ & $98.1 \pm 2.2$ & $38.7 \pm 6.1^{\mathrm{a}}$ & $75.4 \pm 5.5$ \\
\hline$(+)$ & 8 & 69 & $92.5 \pm 2.7$ & $89.9 \pm 3.0$ & $21.2 \pm 8.7^{\mathrm{bc}}$ & $58.2 \pm 7.8$ \\
\hline$(-)$ & 8 & 57 & $94.6 \pm 2.8$ & $94.6 \pm 3.1$ & $13.4 \pm 8.9^{c}$ & $65.0 \pm 8.0$ \\
\hline
\end{tabular}

Expanded blastocysts vitrified from 17 culture replicates and warmed in 10 replicates. Data are LSM of replicates \pm s.e.m.

${ }_{a, b, c}$ Values within columns with different superscript letters differ significantly $\mathrm{P}<0.025$.

\subsubsection{Embryo transfer to recipients and birth}

Embryos were transferred to recipients after vitrification and warming (Table 3.5). Birth rates tended to increase $(P=0.059)$ without protein. Interestingly, no differences were observed in pregnancy rates on Days 40 and 62, but an increased miscarriage rate took place after Day 40 in embryos cultured with protein $(P<0.02)$. The paternal side did not affect the long-term outcome of embryo transfer. Thus, in the group of embryos cultured with protein, miscarriages $(n=6)$ were represented among $n=6$ different bulls (Table 3.6). In contrast, only $n=1$ miscarriage occurred within embryos cultured in proteinfree medium. The absence of protein did not subsequently affect calving weight, gestation length, height, thorax circumference or fetal daily growth (Table 6). However, calves $\geq 50 \mathrm{~kg}$ were born from embryos cultured in medium with $(n=1 / 15)$ and without $(n=3 / 12)$ protein (non-significant differences; $P>0.54)$. Birthweights per donor breed (Asturiana, $42.8 \pm 3.9$; Holstein, $39.2 \pm 3.5$ ) were consistent with 
published breed averages by artificial insemination (Asturiana, $40.5 \pm 7.4$,

Gutiérrez et al. 2007; Holstein, $43.4 \pm 4.3$, Lazzari et al. 2002).

Table 3.5. Bodyweight (BW), calves with bodyweight larger than $50 \mathrm{~kg}(\geq 50 \mathrm{~kg})$, height at withers (HW), thorax circumference (TC), gestation length (GL) and average fetal daily weight gain (DG) of IVP calves born after transfer of bovine vitrified-warmed Day-7 expanded blastocysts derived from Day- 6 embryos cultured individually in $12 \mu \mathrm{L}$ of synthetic oviduct fluid medium with protein $\left(6 \mathrm{mg} \mathrm{mL}^{-1}\right.$ BSA) or without protein $(0.5 \mathrm{mg}$ $\mathrm{mL}^{-1}$ PVA)

\begin{tabular}{lccccccc}
\hline Protein & $\boldsymbol{n}$ & $\begin{array}{c}\mathbf{B W} \\
\mathbf{( K g )}\end{array}$ & $\begin{array}{c}\boldsymbol{n} \geq \mathbf{5 0 K g} \\
(\%)\end{array}$ & $\begin{array}{c}\mathbf{H W} \\
\mathbf{( c m})\end{array}$ & $\begin{array}{c}\text { TC } \\
(\mathbf{c m})\end{array}$ & $\begin{array}{c}\text { GL } \\
(\text { days })\end{array}$ & $\begin{array}{c}\text { DG } \\
\text { (g/day) }\end{array}$ \\
\hline$(+)$ & 15 & $41.4 \pm 2.5$ & $1(7)$ & $75.2 \pm 2.7$ & $78.0 \pm 1.9$ & $280 \pm 1.5$ & $148 \pm 9$ \\
$(-)$ & 12 & $45.6 \pm 3.7$ & $3(25)$ & $81.2 \pm 3.9$ & $79.4 \pm 2.8$ & $283 \pm 2.2$ & $150 \pm 13$ \\
$\mathrm{P}=$ & & 0.39 & 0.54 & 0.50 & 0.79 & 0.31 & 0.47 \\
\hline
\end{tabular}

Data are LSM \pm s.e.m. of average calf values.

Pregnancies were allowed to reach term naturally (no labour induction)

Table 3.6. Embryo transfers $(n)$ performed per bull, with expression of Day-40 pregnancies and miscarriage attained.

\begin{tabular}{|c|c|c|c|c|c|c|c|}
\hline \multirow[b]{2}{*}{ Bull } & \multirow[b]{2}{*}{$\begin{array}{l}\text { Sex } \\
\text { Sorted }\end{array}$} & \multicolumn{3}{|c|}{ Protein (+) } & \multicolumn{3}{|c|}{ Protein (-) } \\
\hline & & $\begin{array}{l}\text { ET } \\
(n)\end{array}$ & Day-40 & Miscarriage & $\begin{array}{l}\text { ET } \\
(n)\end{array}$ & Day-40 & Miscarriage \\
\hline $\mathrm{A}$ & No & 5 & 2 & 1 & 9 & 6 & 0 \\
\hline B & No & 2 & 1 & 1 & 6 & 4 & 1 \\
\hline C & Female & 6 & 4 & 1 & & & \\
\hline C & Male & 3 & 2 & 1 & & & \\
\hline $\mathrm{F}$ & No & 3 & 1 & in course & 5 & 2 & in course \\
\hline G & Female & 3 & 1 & 1 & & & \\
\hline $\mathrm{H}$ & Female & 1 & 0 & & 2 & 1 & 0 \\
\hline I & Female & 5 & 3 & 1 & 4 & 2 & 0 \\
\hline I & Male & 4 & 1 & 0 & & & \\
\hline$J$ & No & 9 & 4 & 0 & & & \\
\hline K & Male & 3 & 2 & 0 & 1 & 0 & \\
\hline $\mathrm{K}$ & Female & 3 & 1 & 0 & & & \\
\hline Total & & 47 & 22 & 6 & 27 & 14 & 1 \\
\hline
\end{tabular}

\subsubsection{Gene expression study}

Gene expression was analysed in blastocysts before and after vitrification and warming. For fresh embryos analysed on Day 7 (Fig. 3.1a) cultured without protein, expression of the imprinting related gene IGF2R was higher $(P<0.03)$ and DNMT3A tended to increase ( $P=0.062$; not shown in figures). In addition, 
the genes ATF4 and DDIT3, markers of endoplasmic reticulum stress, showed higher abundance in embryos cultured in protein free medium $(P<0.03)$. After vitrification and warming (Fig. 3.1b), hatched blastocysts showed no changes in any of the analysed genes with the exception of G6PD, the pentosephosphate pathway rate-limiting enzyme, which was significantly overexpressed in embryos cultured without protein $(P<0.01)$.

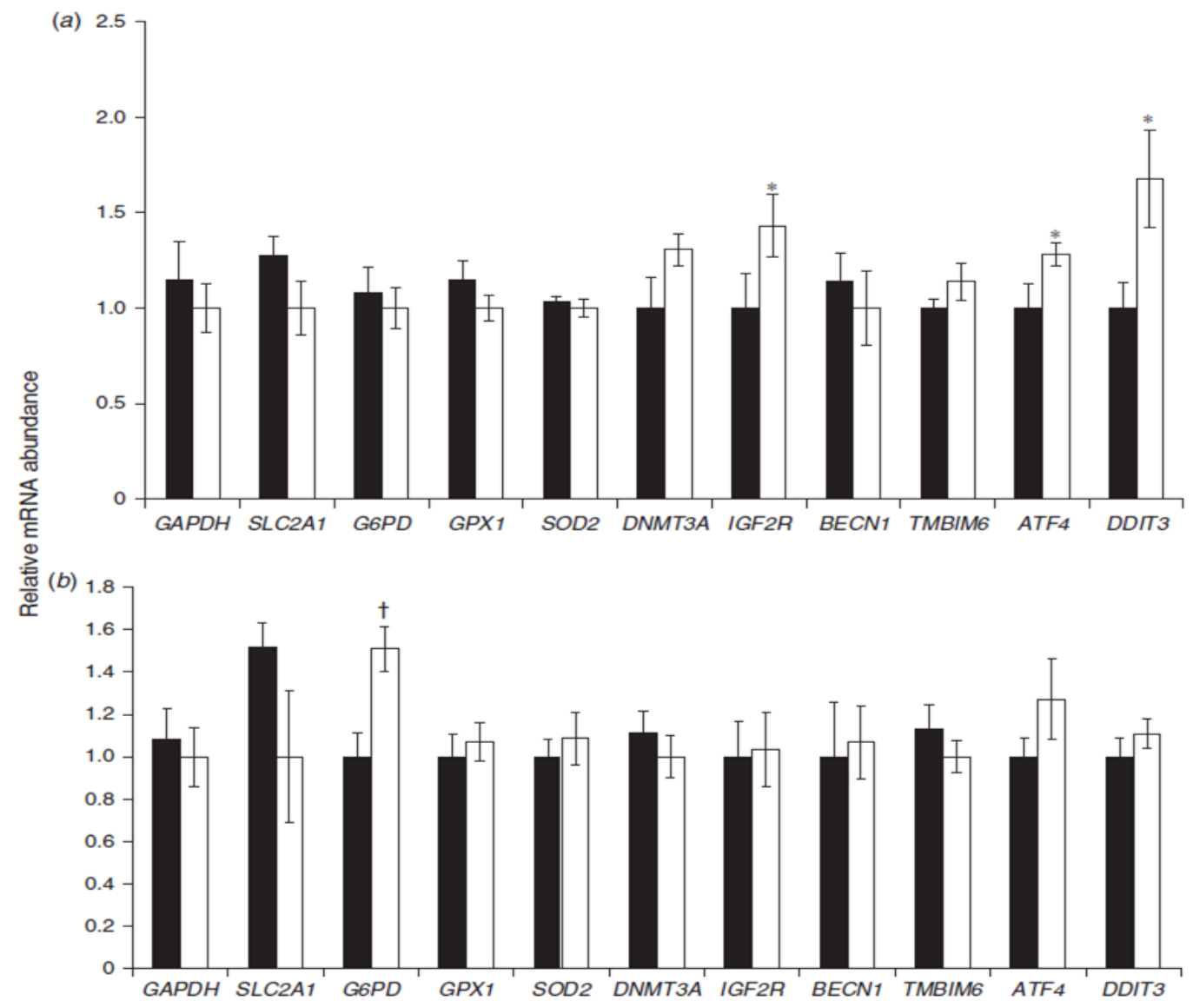

Fig. 3.1. Relative abundance (LSM \pm s.e.m.; $n=4$ replicates) of $m R N A$ transcribed from genes representing metabolism (GAPDH, SLC2A1, G6PD), oxidative stress (GPX1, SOD2), imprinting mechanisms (DNMT3A, IGF2R) and endoplasmic reticulum stress (BECN1, TMB1B6, ATF4, $D D I T 3)$. Analysis was performed on (a) pools of Day-7 fresh expanded blastocysts $(n=10)$ and on (b) pools of hatched blastocysts $(n=6)$ that survived $24 \mathrm{~h}$ in vitro after vitrification and warming of Day-7 expanded blastocysts derived from Day- 6 embryos cultured individually in 12 $\mu \mathrm{L}$ of synthetic oviduct fluid medium with protein $\left(6 \mathrm{mg} \mathrm{mL}^{-1} \mathrm{BSA}\right.$; solid bars) or without protein (0.5 $\mathrm{mg} \mathrm{mL}^{-1} \mathrm{PVA}$; open bars). Superscripts express significant differences: ${ }^{\star} P<0.03, \dagger P<0.01$.

\subsubsection{Sex analysis of Day-7 blastocysts}


As G6PD can be overexpressed by female bovine embryos (Gutiérrez-Adán et al. 2000; Gutiérrez-Adán et al. 2004), we performed a sex determination study in expanded blastocysts. We did not find significant $(P>0.14)$ differences in the male: female ratio $(M: F)$ for embryos cultured with and without protein $(M: F=$ 51 and $\mathrm{M}: \mathrm{F}=57$, with $n=50$ and $n=40$ embryos sexed, respectively; not shown in tables).

\subsection{Discussion}

In this study we analysed the short- and long-term effects of the absence of protein during bovine blastocyst formation in vitro. Overall, the absence of protein during the morula-to-blastocyst transition yields fewer blastocysts but with improved developmental competence.

The absence of protein in culture is expected to impact embryonic protein and amino-acid stocks and metabolism. Interestingly, none of the classical carbohydrate sources provided for the embryo (glucose, lactate, pyruvate and citrate) was consumed by bovine in vivo embryos that were cultured in vitro or by embryos from pig, mouse and human (Krisher et al. 2015). In contrast, amino acids appear to be the main compounds consumed by embryos (Krisher et al. 2015; aspartate and serine consumed by cattle embryos).

In this study, the absence of protein from Day 6 reduced blastocyst and expansion rates on Days 7 and 8 , as well as cell counts in the ICM. These effects are not surprising, as protein absence can negatively impact embryo development and cell counts in group embryo culture (Krisher et al. 1999; Duque et al. 2003; Orsi and Leese 2004). In cows, beneficial effects of protein are observed preferentially in long-term culture in vitro, whereby the absence of 
protein is clearly detrimental, particularly in the second part of the culture (4 days; Krisher et al. 1999; Duque et al. 2003; Orsi and Leese 2004). Similar studies proposed that post-compaction stages would require more protein than earlier stages (Thompson et al. 1998), consistent with our current results and with previous work (Gómez et al.2014). After vitrification and warming, the absence of protein resulted in subtle benefits for Day-7 embryo survival in vitro. Since virtually all embryos were able to re-expand after $2 \mathrm{~h}$ of culture, this timeconsuming and cost-increasing operation can now be suppressed for Day-7 embryos cultured for $24 \mathrm{~h}$ in protein-free medium. An important fact is that not one blastocyst hatched on Day 7 in culture without protein, while 5/144 embryos cultured with protein hatched (data not shown); this reduces sanitary constraints, as the use of embryos with shed zona pellucida is normally discouraged for cryopreservation and international exchanges (Stringfellow 2010). The reduction in the ICM cell count in embryos cultured without protein contrasts with the superior long-term viability shown by such embryos in the uterus. Thus, although it is generally assumed that minimum numbers of embryonic cells are necessary to establish pregnancy (Iwasaki et al. 1990), the optimal cell number and distribution of ICM and TE in the blastocyst are unclear. Higher cell counts in the ICM may lead to increased pregnancy rates (Loureiro et al. 2009). Conversely, embryos cultured in BSA-free medium showed no changes in cell counts and higher pregnancy rates than embryos cultured with BSA (Lim et al. 2007). In agreement with our findings, Lazzari et al. (2002) found that the in vivo environment (i.e. sheep oviduct) led to decreased cell counts as compared with in vitro culture in SOF with BSA or serum. We may conclude that the differences in birth and miscarriage rates 
were not predicted from in vitro survival experiments. In our study, protein withdrawal led to reduced late miscarriage rates, suggesting that such a protein removal step is beneficial for pregnancy to term. In fact, cattle blastocysts living in the uterus trigger a decrease in both secreted uterine fluid volume, measured as total recoverable protein, and specifically albumin (Muñoz et al. 2012). As uterine passage is beneficial to embryonic viability and survival of cryopreservation (Rizos et al. 2002; Lonergan et al. 2004; Havlicek et al. 2010), the long-term beneficial effects we observed after a brief protein deprivation during late blastocyst development in vitro could be physiologically supported. Although no effect was observed on birthweight, from a nutritional perspective, 24-h protein-free in vitro cultures may reflect, to a certain extent, early protein restriction in the uterine fluid of mother cows. In mice, blastocysts recovered from mothers fed with a low-protein diet during blastocyst development and transferred to non-restricted mothers result in heavier fetuses, showing that blastocyst growth can be programmed independent of the subsequent dietary environment (Watkins et al. 2008). In cattle, birthweight increased after the transfer of embryos cultured in vitro in SOF with serum or $16 \mathrm{~g} \mathrm{~L}^{-1} \mathrm{BSA}$ (Lazzari et al. 2002), a concentration higher than that used in the present study. Such a study reported more than $50 \%$ calves $50 \mathrm{~kg}$, in contrast with the lower proportion of large calves in our study (although more cases are necessary). Similar results were obtained by van Wagtendonck-de Leeuw et al. (2000) with an unknown BSA concentration. Dairy cows suffering negative energy balance (Leroy et al. 2015), which provides a metabolically altered embryonic environment, showed increased pregnancy losses during the first 60 days. In 
contrast, our embryos with restricted protein showed limited presence (metabolic) or complete absence (oxidative) of genes expressing damage.

We found that the upregulation of IGF2R under protein removal resembles more physiological conditions than embryos cultured with protein. In contrast, downregulation of the imprinted gene IGF2R has been linked to fetal overgrowth (Young et al. 2001) and abortion in cattle clones (Yang et al.2013). In addition, dysregulation of specific paternal imprinting in the regulatory region of IGF2R (Bebbere et al. 2013) may explain the high incidence of placental failures in somatic cell nuclear transfer (SCNT) and IVP embryos (Heyman et al. 2002; Constant et al. 2006). Our embryos cultured with protein showed increased abortion rates, but no overweight fetuses were detected at birth. In fact, in vivo-developed conceptuses differ in the methylation status of IGF2R compared with IVP and SCNT conceptuses (Smith et al. 2015). These changes are not observed in individuals when born, regardless of their health status, which may explain the selective elimination of embryos carrying harmful epimutations before birth (Smith et al. 2015). During early development, stress sensitivity occurs at the time of nutritionally demanding processes, such as transcriptional activity during compaction, ion pumping required for blastocoel formation and lineage differentiation (Puscheck et al. 2015). Stressors such as nutrient starvation activate autophagy, a prosurvival process linked to endoplasmic reticulum (ER) stress that contributes to the recycling of old proteins and organelles.

In bovine embryos, inducing autophagy increases blastocyst development and trophectoderm cells and also reduces apoptosis, while autophagy inhibition counteracts these effects (Song et al. 2012). We hypothesised that recycling 
proteins could be critical under protein restriction from Day-6 morula stage onwards, a time frame for stress sensitivity. The lack of differences in GPX1 and SOD2, mitochondria-associated antioxidant enzyme-coding genes, indicates an absence of oxidative stress induced by protein withdrawal both before and after cryopreservation. In contrast, we found ATF4 and DDIT3 overexpressed in Day-7 blastocysts that were deprived of protein before cryopreservation, which confines the stress scope of protein restriction to the ER. Interestingly, these differences, together with the increased expression of IGF2R in fresh embryos, were not observed in hatched blastocysts that survived cryopreservation. In contrast, the absence of protein (Lim et al. 2007) and different systems of in vitro culture (with serum or BSA) did not alter the expression of IGF2R regarding in vivo development in the ovine oviduct or in the cow (Lazzari et al. 2002).

Suppressing ER stress appears to entail short-term beneficial effects on blastocyst development and quality (i.e. our protein group; Song et al. 2011, 2012; Yoon et al. 2014), while we have provided evidence of contrasting effects on pregnancy establishment and term development. Our results indicate that the absence of protein leads to ER stress beneficial for pregnancy maintenance and long-term viability.

Cryopreservation is a recognised stress source for embryos (Puscheck et al. 2015) so removal of stress markers after warming suggests that a certain grade of selection would take place. Interestingly, the different expression of IGF2R between groups also disappeared after warming and hatching in vitro.

This way, specific cohorts of embryos that hatch after warming would be able to progress through pregnancy to term, regardless of whether their culture 
contained protein or not. Vitrification and warming suppressed differences in gene expression first observed in fresh embryos, leading to overexpression of G6PD in hatched blastocysts cultured without protein after warming. Activation of G6PD is indicative of response to oxidative stress and, in bovine blastocysts, may constitutively indicate dosage differences depending on embryonic sex (Gutiérrez-Adán et al. 2000; Kimura et al. 2004, 2005). Males and females differ in their resistance to heat-induced oxidative stress (Pérez-Crespo et al. 2005). In our study, nevertheless, no evidence of sex selection was observed during the morula-to-expanded blastocyst transition. Therefore, increases in G6PD should be associated with more viable and less miscarriage-producing embryos cultured in the absence of protein, perhaps reflecting a superior ability to counteract oxidative stress induced by cryopreservation. In cows and sheep increased G6PD activity is also observed in oocytes having lower lipid content (Castaneda et al. 2013; Mohammadi-Sangcheshmeh et al. 2014). Interestingly, fatty-acid carriage and uptake by albumin alters the fatty acid profile and enhances oxidative stress (Hughes et al. 2011), so culture without BSA could entail reduced lipid content in embryos, as shown in pigs (Romek et al. 2011). This investigation is in progress.

Many of the effects observed without protein are consistent with the quiet embryo hypothesis (Leese 2002; Leese et al. 2008), which suggests that viable embryos show low metabolic activity (including diminished amino-acid turnover and glycolysis). These 'best' embryos would respond better to stressors or would not need to respond to stressors. Removal of protein in culture may favour development of non-protein-dependent embryos (somewhat quiet), which could bear traits of improved viability such as higher survival of 
cryopreservation. Protein absence on Day 6 and individual culture is potentially compatible with any other culture step before Day 6 given that individual culture provides blastocyst development equal to group culture and hatching rates that are superior to group culture (Muñoz et al.2014b). Even more interesting is the fact that, in the presence of protein, pregnancy rates with fresh IVP embryos were similar to fresh in vivo embryos cultured in vitro for $24 \mathrm{~h}$ (Muñoz et al. $2014 a, 2014 b)$. In the present study with vitrified embryos, the absence of protein led to a notable trend to increased birth rates by means of reducing miscarriage, which represents counteracting the cost-expensive and production damaging late-pregnancy losses in cattle farming. Interestingly, protein removal during blastocyst formation did not affect birthweight, gestation length or calf morphology. However, more studies are necessary to delineate these findings appropriately. Furthermore, individual culture provides rapid and direct access to $\mathrm{CM}$ as a substrate for non-invasive analysis, leading to biomarker discovery for prediction of pregnancy rates (Muñoz et al. 2014a, 2014b) or amino-acid turnover (Sturmey et al. 2010) and embryonic sex (Muñoz et al. 2014c). Users wishing to improve survival upon cryopreservation may allocate embryos to protein-free culture media in time with recipient availability or embryo surplus.

\subsection{References}

Bebbere, D., Bauersachs, S., Fürst, R. W., Reichenbach, H. D., Reichenbach, M., Medugorac, I., Ulbrich, S. E., Wolf, E., Ledda, S., and Hiendleder, S. (2013). 
Tissue-specific and minor inter-individual variation in imprinting of IGF2R is a common feature of Bos taurus concepti and not correlated with fetal weight. PLoS One 8, e59564. doi:10.1371/JOUR NAL.PONE.0059564

Bermejo-Álvarez, P., Rizos, D., Rath, D., Lonergan, P., and Gutiérrez-Adán, A. (2008). Epigenetic differences between male and female bovine blastocysts produced in vitro. Physiol. Genomics 32, 264-272. doi:10.1152/PHYSIOLGENOMICS.00234.2007

Caamaño, J. N., Gómez, E., Trigal, B., Muñoz, M., Carrocera, S., Martín, D., and Díez, C. (2015). Survival of vitrified in vitro-produced bovine embryos after a one-step warming in-straw cryoprotectant dilution procedure. Theriogenology 83, 881-890. doi:10.1016/J.THERIOGENOLOGY.2014.11.021

Castaneda, C. A., Kaye, P., Pantaleon, M., Phillips, N., Norman, S., Fry, R., and D'Occhio, M. J. (2013). Lipid content, active mitochondria and brilliant cresyl blue staining in bovine oocytes. Theriogenology 79, 417-422. doi:10.1016/J.THERIOGENOLOGY.2012.10.006

Constant, F., Guillomot, M., Heyman, Y., Vignon, X., Laigre, P., Servely, J. L., Renard, J. P., and Chavatte-Palmer, P. (2006). Large offspring or large placenta syndrome? Morphometric analysis of late gestation bovine placentomes from somatic nuclear transfer pregnancies complicated by hydrallantois. Biol. Reprod. 75, 122-130. doi:10.1095/BIOL REPROD.106.051581

Duque, P., Hidalgo, C. O., Gómez, E., Pintado, B., Facal, N., and Díez, C. (2003). Macromolecular source as dependent on osmotic pressure and water source: effects on bovine in vitro embryo development and quality. Reprod. Nutr. Dev. 43, 487-496. doi:10.1051/RND:2004007

Francis, G. L. (2010). Albumin and mammalian cell culture: implications for biotechnology applications. Cytotechnology 62, 1-16. doi:10.1007/S10616010-9263-3

Gómez, E., Royo, L. J., Duque, P., Carneiro, G., Hidalgo, C., Goyache, F.,Lorenzo, P. L., Alvarez, I., Facal, N., and Díez, C. (2003). 9-cis-retinoic acid during in vitro maturation improves development of the bovine oocyte and increases midkine but not IGF-I expression in cumulus-granulosa cells. Mol. Reprod.Dev. 66, 247-255. doi:10.1002/MRD.10307

Gómez, E., Rodríguez, A., Goyache, F., Díez, C., Royo, J. L., Moreira, P. N., Caamaño, J. N., Morán, E., and Gutiérrez-Adán, A. (2004). Retinoid dependent mRNA expression and poly-(A) contents in bovine oocytes meiotically arrested and/or matured in vitro. Mol. Reprod. Dev. 69, 101-108. doi:10.1002/MRD.20154

Gómez, E., Rodríguez, A., Muñoz, M., Caamaño, J. N., Hidalgo, C. O., Morán, E., Facal, N., and Díez, C. (2008a). Serum-free embryo culture medium 
improves in vitro survival of bovine blastocysts to vitrification. Theriogenology 69, 1013-1021. doi:10.1016/J.THERIOGENOLOGY. 2007.12.015

Gómez, E., Rodríguez, A., Muñoz, M., Caamaño, J. N., Carrocera, S., Martín, D., Facal, N., and Díez, C. (2008b). Development and quality of bovine morulae cultured in serum-free medium with specific retinoid receptor agonists. Reprod. Fertil. Dev. 20, 884-891. doi:10.1071/RD08103

Gómez, E., Correia-Álvarez, E., Caamaño, J. N., Díez, C., Carrocera, S.,Peynot, N., Martín, D., Giraud-Delville, C., Duranthon, V., Sandra, O., and Muñoz, M. (2014). Hepatoma-derived growth factor: from the bovine uterus to the in vitro embryo culture. Reproduction 148, 353-365. doi:10.1530/REP14-0304

Goovaerts, I. G., Leroy, J. L., Jorssen, E. P., and Bols, P. E. (2010). Noninvasive bovine oocyte quality assessment: possibilities of a single oocyte culture. Theriogenology $74, \quad 1509-1520$. doi:10.1016/J.THERIOGENOLOGY.2010.06.022

Gutiérrez, J. P., Goyache, F., Fernández, I., Álvarez, I., and Royo, L. J. (2007). Genetic relationships among calving ease, calving interval, birth weight and weaning weight in the Asturiana de los Valles beef cattle breed. J. Anim. Sci. 85, 69-75. doi:10.2527/JAS.2006-168

Gutiérrez-Adán, A., Oter, M., Martínez-Madrid, B., Pintado, B., and De La Fuente, J. (2000). Differential expression of two genes located on the $X$ chromosome between male and female in vitro-produced bovine embryos at the blastocyst stage. Mol. Reprod. Dev. 55, 146-151. doi:10.1002/(SICI)1098-2795(200002)55:2,146::AID-MRD3.3.0.CO;2-F

Gutiérrez-Adán, A., Rizos, D., Fair, T., Moreira, P. N., Pintado, B., de la Fuente, J., Boland, M. P., and Lonergan, P. (2004). Effect of speed of development on mRNA expression pattern in early bovine embryos cultured in vivo or in vitro. Mol. Reprod. Dev. 68, 441-448. doi:10.1002/ MRD.20113

Hasler, J. F. (2000). In vitro production of cattle embryos: problems with pregnancies and parturition. Hum. Reprod. 15(Suppl 5), 47-58. doi:10.1093/HUMREP/15.SUPPL_5.47

Havlicek, V., Kuzmany, A., Cseh, S., Brem, G., and Besenfelder, U. (2010). The effect of long-term in vivo culture in bovine oviduct and uterus on the development and cryo-tolerance of in vitro-produced bovine embryos. Reprod. Domest. Anim. 45, 832-837.

Heyman, Y., Chavatte-Palmer, P., LeBourhis, D., Camous, S., Vignon, X., and Renard, J. P. (2002). Frequency and occurrence of late-gestation losses from cattle cloned embryos. Biol. Reprod. 66, 6-13. doi:10.1095/BIOLREPROD66.1.6 
Hidalgo, C. O., Díez, C., Duque, P., Facal, N., and Gómez, E. (2003). Pregnancies and improved early embryonic development with bovine oocytes matured in vitro with 9-cis-retinoic acid. Reproduction 125, 409416. doi:10.1530/REP.0.1250409

Hidalgo, C. O., Gómez, E., Prieto, L., Duque, P., Goyache, F., Fernández, L., Fernández, I., Facal, N., and Díez, C. (2004). Pregnancy rates and metabolic profiles in cattle treated with propylene glycol prior to embryo transfer. Theriogenology 62, 664-676. doi:10.1016/J.THERIOGENOLOGY.2003.11.006

Hidalgo, C., Díez, C., Duque, P., Prendes, J. M., Rodríguez, A., Goyache, F., Fernández, I., Facal, N., Ikeda, S., Alonso-Montes, C., and Gómez, E. (2005). Oocytes recovered from cows treated with retinol become unviable as blastocysts produced in vitro. Reproduction 129, 411-421. doi:10.1530/REP.1.00548

Hughes, J., Kwong, W. Y., Li, D., Salter, A. M., Lea, R. G., and Sinclair, K. D. (2011). Effects of omega-3 and -6 polyunsaturated fatty acids on ovine follicular cell steroidogenesis, embryo development and molecular markers of fatty-acid metabolism. Reproduction 141, 105-118. doi:10.1530/REP-10-0337

Iwasaki, S., Yoshiba, N., Ushijima, H., Watanabe, S., and Nakahara, T. (1990). Morphology and proportion of inner cell mass of bovine blastocysts fertilised in vitro and in vivo. J. Reprod. Fertil. 90, 279-284. doi:10.1530/JRF.0.0900279

Kimura, K., Spate, L. D., Green, M. P., and Roberts, R. M. (2004). Effects of oxidative stress and inhibitors of the pentose phosphate pathway on sexually dimorphic production of IFN-tau by bovine blastocysts. Mol. Reprod. Dev. 68, 88-95. doi:10.1002/MRD.20053

Kimura, K., Spate, L. D., Green, M. P., and Roberts, R. M. (2005). Effects of Dglucose concentration, D-fructose and inhibitors of enzymes of the pentose phosphate pathway on the development and sex ratio of bovine blastocysts. Mol. Reprod. Dev. 72, 201-207. doi:10.1002/MRD.20342

Krisher, R. L., Lane, M., and Bavister, B. D. (1999). Developmental competence and metabolism of bovine embryos cultured in semi-defined and defined culture media. Biol. Reprod. 60, 1345-1352. doi:10.1095/BIOLREPROD60.6.1345

Krisher, R. L., Schoolcraft, W. B., and Katz-Jaffe, M. G. (2015). Omics as a window to view embryo viability. Fertil. Steril. 103, 333-341. doi:10.1016/J.FERTNSTERT.2014.12.116

Lazzari, G., Wrenzycki, C., Herrmann, D., Duchi, R., Kruip, T., Niemann, H., and Galli, C. (2002). Cellular and molecular deviations in bovine in vitroproduced embryos are related to the large offspring syndrome. Biol. Reprod. 67, 767-775. doi:10.1095/BIOLREPROD.102.004481 
Leese, H. J. (2002). Quiet please, do not disturb: a hypothesis of embryo metabolism and viability. BioEssays 24, 845-849. doi:10.1002/BIES.10137

Leese, H. J., Baumann, C. G., Brison, D. R., McEvoy, T. G., and Sturmey, R. G. (2008). Metabolism of the viable mammalian embryo: quietness revisited. Mol. Hum. Reprod. 14, 667-672. doi:10.1093/MOLEHR/GAN065

Leroy, J. L., Valckx, S. D., Jordaens, L., De Bie, J., Desmet, K. L., Van Hoeck, V., Britt, J. H., Marei, W. F., and Bols, P. E. (2015). Nutrition and maternal metabolic health in relation to oocyte and embryo quality: critical views on what we learned from the dairy cow model. Reprod. Fertil. Dev. doi:10.1071/RD14363

Loureiro, B., Bonilla, L., Block, J., Fear, J. M., Bonilla, A. Q., and Hansen, P. J. (2009). Colony-stimulating factor 2 (CSF-2) improves development and posttransfer survival of bovine embryos produced in vitro. Endocrinology 150, 5046-5054. doi:10.1210/EN.2009-0481

Lim, K. T., Jang, G., Ko, K. H., Lee, W. W., Park, H. J., Kim, J. J., Lee, S. H., Hwang, W. S., Lee, B. C., and Kang, S. K. (2007). Improved in vitro bovine embryo development and increased efficiency in producing viable calves using defined media. Theriogenology 67, 293-302. doi:10.1016/J.THERIOGENOLOGY.2006.07.011

Lonergan, P., Pedersen, H. G., Rizos, D., Greve, T., Thomsen, P. D., Fair, T., Evans, A., and Boland, M. P. (2004). Effect of the post-fertilisation culture environment on the incidence of chromosome aberrations in bovine blastocysts. Biol. Reprod. 71, 1096-1100. doi:10.1095/BIOLREPROD.104.030635

Mohammadi-Sangcheshmeh, A., Veshkini, A., Hajarizadeh, A., JamshidiAdegani, F., Zhandi, M., Abazari-Kia, A. H., Cinar, M. U., Soleimani, M., and Gastal, E. L. (2014). Association of glucose-6-phosphate dehydrogenase activity with oocyte cytoplasmic lipid content, developmental competence and expression of candidate genes in a sheep model. J. Assist. Reprod. Genet. 31, 1089-1098. doi:10.1007/S10815-014-0264-6

Muñoz, M., Corrales, F. J., Caamaño, J. N., Díez, C., Trigal, B., Mora, M. I., Martín, D., Carrocera, S., and Gómez, E. (2012). Proteome of the early embryo-maternal dialogue in the cattle uterus. J. Proteome Res. 11,751766. doi:10.1021/PR200969A

Muñoz, M., Uyar, A., Correia, E., Díez, C., Fernández-González, A., Caamaño, J. N., Martínez-Bello, D., Trigal, B., Humblot, P., Ponsart, C., Guyader-Joly, C., Carrocera, S., Martín, D., Marquant Le Guienne, B., Seli, E., and Gómez, E. (2014a). Prediction of pregnancy viability in bovine in vitro-produced embryos and recipient plasma with Fourier transform infrared spectroscopy. J. Dairy Sci. 97, 5497-5507. doi:10.3168/JDS.2014-8067 
Muñoz, M., Uyar, A., Correia, E., Ponsart, C., Guyader-Joly, C., Martínez- Bello, D., Marquant-Le Guienne, B., Fernández-González, A., Díez, C., Caamaño, J. N., Trigal, B.,Humblot, P., Carrocera, S., Martin,D., Seli, E., and Gómez, E. $(2014 b)$. Metabolomic prediction of pregnancy viability in superovulated cattle embryos and recipients with Fourier transform infrared spectroscopy. BioMed Res. Int. 2014, 608579. doi:10.1155/2014/608579

Muñoz, M., Uyar, A., Correia, E., Díez, C., Fernández-González, A., Caamaño, J. N., Trigal, B., Carrocera, S., Seli, E., and Gómez, E. (2014c). Non-invasive assessment of embryonic sex in cattle by metabolic fingerprinting of in vitro culture medium. Metabolomics 10, 443-451. doi:10.1007/S11306-0130587-9

Orsi, N. M., and Leese, H. J. (2004). Amino-acid metabolism of preimplantation bovine embryos cultured with bovine serum albumin or polyvinyl alcohol. Theriogenology 61, 561-572. doi:10.1016/S0093691X(03)00206-1

Pérez-Crespo, M., Ramírez, M. A., Fernández-González, R., Rizos, D.,Lonergan, P., Pintado, B., and Gutiérrez-Adán, A. (2005). Differential sensitivity of male and female mouse embryos to oxidative induced heat stress is mediated by glucose-6-phosphate dehydrogenase gene expression. Mol. Reprod. Dev. 72, 502-510. doi:10.1002/MRD.20366

Puscheck, E. E., Awonuga, A. O., Yang, Y., Jiang, Z., and Rappolee, D. A. (2015). Molecular biology of the stress response in the early embryo and its stem cells. Adv. Exp. Med. Biol. 843, 77-128. doi:10.1007/978-1-49392480-6_4

Rizos, D., Ward, F., Duffy, P., Boland, M. P., and Lonergan, P. (2002). Consequences of bovine oocyte maturation, fertilisation or early embryo development in vitro versus in vivo: implications for blastocyst yield and blastocyst quality. Mol. Reprod. Dev. 61, 234-248. doi:10.1002/ MRD.1153

Rodríguez, A., De Frutos, C., Díez, C., Caamaño, J. N., Facal, N., Duque, P., García-Ochoa, C., and Gómez, E. (2007). Effects of human versus mouse leukaemia inhibitory factor on the in vitro development of bovine embryos. Theriogenology 67, 1092-1095. doi:10.1016/J.THERIOGENOLOGY.2006.11.015

Romek, M., Gajda, B., Krzysztofowicz, E., Kepczyn'ski, M., and Smorag, Z. (2011). Lipid content in pig blastocysts cultured in the presence or absence of protein and vitamin $E$ or phenazine ethosulfate. Folia Biol. (Krakow) 59, 45-52. doi:10.3409/FB59_1-2.45-52

Schmittgen, T. D., and Livak, K. J. (2008). Analysing real-time PCR data by the comparative $\mathbf{C}(\mathbf{T})$ method. Nat. Protoc. 3, 1101-1108. doi:10.1038/NPROT.2008.73 
Smith, L. C., Therrien, J., Filion, F., Bressan, F., and Meirelles, F. V. (2015). Epigenetic consequences of artificial reproductive technologies to the bovine imprinted genes SNRPN, H19/IGF2, and IGF2R. Front. Genet. 6, 58. doi:10.3389/FGENE.2015.00058

Song, B. S., Kim, J. S., Yoon, S. B., Lee, K. S., Koo, D. B., Lee, D. S., Choo, Y. K., Huh, J. W., Lee, S. R., Kim, S. U., Kim, S. H., Kim, H. M., and Chang, K. T. (2011). Inactivated Sendai virus-mediated fusion improves early development of cloned bovine embryos by avoiding endoplasmic reticulum-stress-associated apoptosis. Reprod. Fertil. Dev. 23, 826836.doi:10.1071/RD10194

Song, B. S., Yoon, S. B., Kim, J. S., Sim, B. W., Kim, Y. H., Cha, J. J., Choi, S. A., Min, H. K., Lee, Y., Huh, J. W., Lee, S. R., Kim, S. H., Koo, D. B.,Choo, Y. K., Kim, H. M., Kim, S. U., and Chang, K. T. (2012). Induction of autophagy promotes preattachment development of bovine embryos by reducing endoplasmic reticulum stress. Biol. Reprod. 87, 8. doi:10.1095/ BIOLREPROD.111.097949

Stringfellow, D. A. (2010) Recommendations for the sanitary handling of in vivo-derived embryos. In 'Manual of the InternationalEmbryo Transfer Society'. 4th edn. (Eds D. A. Stringfellow andM. D. Givens.) pp. 65-68. (International Embryo Transfer Society: Savoy, IL, USA.)

Sturmey, R. G., Bermejo-Alvarez, P., Gutierrez-Adan, A., Rizos, D., Leese, H. J., and Lonergan, P. (2010). Amino-acid metabolism of bovine blastocysts: a biomarker of sex and viability. Mol. Reprod. Dev. 77, 285-296. doi:10.1002/MRD.21173

Thompson, J. G., Sherman, A. N., Allen, N. W., McGowan, L. T., and Tervit, H. $R$. (1998). Total protein content and protein synthesis within preelongation stage bovine embryos. Mol. Reprod. Dev. 50, 139-145. doi:10.1002/(SICI)1098-795(199806)50:2,139::AIDMRD3.3.0.CO;2-L

Trigal, B., Gómez, E., Caamaño, J. N., Muñoz, M., Moreno, J., Carrocera, S., Martín, D., and Díez, C. (2012a). In vitro and in vivo quality of bovine embryos in vitro produced with sex-sorted spermatozoa. Theriogenology 78, 1465-1475. doi:10.1016/J.THERIOGENOLOGY.2012.06.018

Trigal, B., Gómez, E., Díez, C., Caamaño, J. N., Muñoz, M., Moreno, J. F., Carrocera, S., Martín, D., Goyache, F., and Álvarez, I. (2012b). Comparative study of PCR-sexing procedures using bovine embryos fertilised with sexsorted spermatozoa. Span. J. Agric. Res. 10, 353-359. doi:10.5424/SJAR/2012102-447-11

Vajta, G., Holm, P., Kuwayama, M., Booth, P. J., Jacobsen, H., Greve, T., and Callesen, H. (1998). Open pulled straw (OPS) vitrification: a new way to reduce cryoinjuries of bovine ova and embryos. Mol. Reprod. Dev. 51, 5358. doi:10.1002/(SICI)1098-2795(199809)51:1,53::AIDMRD6.3.0.CO;2-V 
van Wagtendonk-de Leeuw, A. M., Mullaart, E., de Roos, A. P., Merton, J. S., den Daas, J. H., Kemp, B., and de Ruigh, L. (2000). Effects of different reproduction techniques: Al MOET or IVP, on health and welfare of bovine offspring. Theriogenology 53, 575-597. doi:10.1016/ S0093-691X(99)00259-9

Watkins, A. J., Ursell, E., Panton, R., Papenbrock, T., Hollis, L., Cunningham, C., Wilkins, A., Perry, V. H., Sheth, B., Kwong, W. Y., Eckert, J. J., Wild, A. E., Hanson, M. A., Osmond, C., and Fleming, T. P. (2008). Adaptive responses by mouse early embryos to maternal diet protect fetal growth but predispose to adult-onset disease. Biol. Reprod. 78, 299- 306. doi:10.1095/BIOLREPROD.107.064220

Yang, L., Yu, W., Yan, W. L., and Peng, G. (2013). Expression of insulinlike growth factor 2 receptor (IGF2R), leptin receptor (LEPR) and serum- and glucocorticoid-regulated kinase 1 (SGK1) mRNA in human and bovine pregnancies. Reprod. Fertil. Dev. 25, 205. [Abstract] doi:10.1071/RDV25N1AB116

Yoon, S. B., Choi, S. A., Sim, B. W., Kim, J. S., Mun, S. E., Jeong, P. S., Yang, H. J., Lee, Y., Park, Y. H., Song, B. S., Kim, Y. H., Jeong, K. J., Huh, J. W., Lee, S. R., Kim, S. U., and Chang, K. T. (2014). Developmental competence of bovine early embryos depends on the coupled response between oxidative and endoplasmic reticulum stress. Biol. Reprod. 90, 104. doi:10.1095/BIOLREPROD.113.113480

Yotsushima, K., Sakaguchi, M., Shimizu, M., Okimura, T., and Izaike, Y. (2004). Effects of fatty acid-free bovine serum albumin and fetal calf serum supplementing repair cultures on pre- and post-warm viability of biopsied bovine embryos produced in vitro. J. Reprod. Dev. 50, 471-476. doi:10.1262/JRD.50.471

Young, L. E., Fernandes, K., McEvoy, T. G., Butterwith, S. C., Gutierrez, C. G., Carolan, C., Broadbent, P. J., Robinson, J. J., Wilmut, I., and Sinclair, K. D. (2001). Epigenetic change in IGF2R is associated with fetal overgrowth after sheep embryo culture. Nat. Genet. 27, 153-154. doi:10.1038/84769 


\title{
4 | CAPítulo II
}

\section{Protein in culture and endogenous lipid interact with embryonic stages in vitro to alter calf birthweight after embryo vitrification and warming}

\author{
E. Gómez ${ }^{\mathrm{A}, \mathrm{D}}$, S. Carrocera ${ }^{\mathrm{A}}$, S. Uzbekova ${ }^{\mathrm{B}}, D$. Martín $^{\mathrm{A}}$, A. Murillo $^{\mathrm{A}}, M$. Alonso-Guervós ${ }^{\mathrm{C}}, F_{\text {. }}$ \\ Goyache ${ }^{\mathrm{A}}$ and M. Muñoz ${ }^{\mathrm{A}}$
}

${ }^{A}$ Centro de Biotecnología Animal, SERIDA, Camino de Rioseco 1225, 33394 Gijón, Spain. ${ }^{B}$ Institut National de la Recherche Agronomique, UMR8 Physiologie de la Reproduction et des Comportements, F-37380 Nouzilly, France.

CUnidad de Microscopía Fotónica y Proceso de Imágenes, Servicios Científico Técnicos, Universidad de Oviedo, Instituto Universitario de Oncología de Asturias (IUOPA), 33006 Oviedo, Spain.

Reproduction, Fertility and Development. 2017, 29(10), 1932-1943

Project support was provided by the Spanish Ministry of Economy and Competitiveness (MINECO; project AGL2012- 37772), Principado de Asturias, Plan de Ciencia, Tecnología e Innovación 2013-2017 (GRUPIN 14-114) and FEDER. A. M. was supported by Secretaría Nacional de Educación Superior, Ciencia, Tecnología e Innovación, Ecuador, II Fase 2013. The authors are members of the COST Action FA1201 Epiconcept: Epigenetics and Periconception environment. 


\section{Abstract}

Short-term protein removal in vitro improves long-term blastocyst competence to survive vitrification. We investigated the mechanisms and effects underlying protein removal. Day-6 morulae and early blastocysts were cultured individually with and without protein for $24 \mathrm{~h}$. Development and lipid content were analysed in expanded blastocysts derived from morulae (M-XB) and from early blastocysts (EB-XB). Expression of genes involved in lipid metabolism, stress responses and apoptosis was analysed in fresh and vitrified-warmed $M-X B$ produced with and without protein.

Pregnancy rates, birth rates and birthweight (BW) were recorded after transfer of embryos. Day-7 EB-XB production rates (with, $66.9 \pm 6.2$ and without, $68.8 \pm$ 6.0 protein) were higher than $M-X B$ rates (with, $21.4 \pm 4.6$ and without, $9.4 \pm 4.6$ protein; $P<0.005)$. EB-XB showed fewer lipids than $\mathrm{M}-\mathrm{XB}(P=0.03)$. In fresh $\mathrm{M}-\mathrm{XB}$, expression of sterol regulatory element binding protein (SREBP1) was lower with $(4.1 \pm 2.2)$ than without $(13.6 \pm 2.2)$ protein, contrary to results obtained for Patatin-like phospholipase domain containing 2, Hormone-sensitive lipase and $\mathrm{Bcl}-2$-associated $X$ protein $(P<0.05)$. Protein did not affect pregnancy rates and birth phenotypes $(P>0.05)$. However, BW was higher $(P<$ $0.01)$ in calves born from vitrified M-XB $(48.6 \pm 3.4 \mathrm{~kg})$ than from EB-XB $(39.8 \pm$ $2.9 \mathrm{~kg})$. Such effects were more pronounced in females $(P<0.001)$. Calves from fresh embryos did not show BW differences. These results indicate that embryonic kinetics and vitrification impact birth phenotypes, at least in females. Alterations might involve exogenous protein and mobilisation of lipid stocks. 


\subsection{Introduction}

Early embryo development is a highly dynamic process that can be influenced by numerous factors to which the embryo may adapt. Such adaptive capacity has been termed plasticity and it can have short- and long-term consequences, affecting blastocyst development and quality, the course of pregnancy and progeny health (Watkins et al. 2008). The period before implantation is of particular interest, as it has been identified as a critical window of developmental sensitivity to environmental or nutritional stress (Fleming et al. 2004).

Recently, we have shown that recipients of vitrified-warmed embryos cultured without protein between Day 6 and Day 7 show increased birth rates and reduced late miscarriage rates (Murillo-Ríos et al. 2016). The absence of protein selects embryos with improved developmental competence once vitrified, and we hypothesised that changes in lipid storage and metabolism could accompany the effects of protein removal (Murillo-Ríos et al. 2016). In fact, the culture environment increases lipid content in bovine in vitro-produced (IVP) embryos (Crosier et al. 2001; Lonergan et al. 2003) up to levels higher than that found in vivo collected (IVC) embryos (Crosier et al. 2001; GonzálezSerrano et al. 2013). Bovine IVP blastocysts can develop well in culture with fatty acids (FA; Al Darwich et al. 2010) or with products of FA oxidation (Gómez 1997; Gómez et al. 2002). However, lipid metabolism is altered within IVP embryos when compared with IVC embryos (González-Serrano et al. 2013; Al Darwich et al. 2014). An excess of intracellular lipid increases embryo sensitivity to oxidative stress, chilling and cryopreservation (Abe et al. 2002; Reis et al. 2003; Sudano et al. 2011), and altered survival after cryopreservation may alter 
pregnancy rates, gestation length and birthweight (BW; Bonilla et al. 2014). As the embryo develops to the expanded blastocyst $(\mathrm{XB})$ stage, embryonic cells show fewer lipid granules (Abe et al. 2002; Barceló-Fimbres and Seidel 2011; Sudano et al. 2016) at the same time that they require more protein (Thompson et al. 1998) and amino acids (Guerif et al. 2013). Endocytosed protein maintains the intracellular amino-acid pool (Thompson et al. 1998) and the embryo can readily use amino acids and lipids in the absence of carbohydrates that feed the energy metabolism (reviewed by Krisher et al. 2015). With the onset of morula compaction and during blastocyst formation, energy demands, measured as oxygen and nutrient consumption, increase dramatically mainly due to two processes: (1) protein synthesis necessary for the embryo to initiate net growth and (2) the $\mathrm{Na}^{+} \mathrm{K}^{+}$ATPase transport system that pumps sodium ions into the trophectoderm (TE) to form the blastocoel (Leese et al. 2008). Contrary to the blastocyst, in the morula the ability to use oxygen is still limited, which may hinder lipid catabolism. Protein availability could therefore determine the different lipid mobilisation characteristics of the early blastocyst (EB) and morula (M). Therefore, XB that derive from either morula or early blastocyst stages may show differences in lipid metabolism and viability after cryopreservation.

In the cow, embryos that develop in vitro show deviant kinetics in comparison to in vivo developing embryos (Merton et al. 2003; Sugimura et al. 2012; Liang et al. 2015). A known form of altered kinetics of bovine embryos is slow cleavage, which reduces development, with higher proportions of chromosomal abnormality, although slow-developing embryos may not show reduced pregnancy rates (Lonergan et al. 1999; Sugimura et al. 2012). Nevertheless, within embryos cleaving slowly, the incidence of abnormal direct passage from 
one cell to 3-4 cells is higher than within fast-cleaving embryos (Sugimura et al. 2012). Altered passage also results in a higher incidence of chromosomal abnormality but lower pregnancy rates (Sugimura et al. 2010, 2012). Development patterns have not been thoroughly researched in the cow, despite the interest of studying developmental kinetics and its influence on neonatal phenotypes (Sugimura et al. 2012). In cattle, Merton et al. (2003) found that pregnancy rates increased when selecting Day-7 embryos for transfer as being derived from 'correct' Day-6 stage embryos. It could be that superior viability embryos are those that develop according to specific patterns (Gutiérrez-Adán et al. 2015) rather than embryos at specific embryonic stages. Kinetic studies in bovine embryos have usually analysed different stage endpoints, but not a same developmental endpoint reached by embryos that progressed from different earlier stages. The in utero development of IVP embryos bearing different development patterns to the $\mathrm{XB}$ stage is also unknown. Different embryonic development patterns can also be favoured by or adapted to changing progesterone (P4) concentrations, as early embryo development is dependent on the rate and timing of the P4 rise (Mann and Lamming 2001; Kenyon et al. 2013).

In this work we hypothesised that protein removal from in vitro culture would affect lipid content and underlying gene expression mechanisms differently depending on the embryonic stage affected. Therefore, we studied how specific embryonic stages develop under protein removal in terms of lipid content, embryonic sex ratio, embryo vitrification and calf phenotypes at birth. 


\subsection{Materials and Methods}

All experimental procedures were approved by the Animal Research Ethics Committee of SERIDA (Agreement 02/02/2012), in accordance with the European Community Directive 86/609/EC. Ovaries were collected from cows that were slaughtered in commercial abattoirs (Matadero de Leon and Matadero de Guarnizo, mostly for Holstein ovaries and Matadero de Tineo for Asturiana de los Valles ovaries). Ovaries were transported to the laboratory in $9 \mathrm{mg} \mathrm{mL}^{-1}$ $\mathrm{NaCl}$ solution with100 $\mathrm{IU} \mathrm{mL} \mathrm{m}^{-1}$ penicillin and $100 \mathrm{mg} \mathrm{mL}^{-1}$ streptomycin sulphate and maintained at $25-30^{\circ} \mathrm{C}$. All reagents were purchased from Sigma unless otherwise stated.

\subsubsection{Embryo production}

In vitro-produced embryos were obtained as described (Trigal et al. 2012a) with minor modifications. Antral follicles (3-8mm in diameter) were aspirated through an 18-g needle connected to a syringe. Aspirated fluid was expelled into dishes containing holding medium (HM): TCM199 (Invitrogen), 25mM 4-(2Hydroxyethyl) piperazine-1-ethanesulfonic acid, N-(2-Hydroxyethyl) piperazineN0-(2-ethanesulfonic acid (HEPES) and $0.4 \mathrm{~g} \mathrm{~L}^{-1}$ bovine serum albumin (BSA) and a stereomicroscope was used to search for oocytes. Only good-quality oocytes with more than three layers of compact cumulus cells with homogenous cytoplasms were selected. For in vitro maturation (IVM), the cumulus-oocyte complexes (COCs) were rinsed three times in HM. Selected COCs were washed three times in maturation medium (MM) consisting of $2.2 \mathrm{~g} \mathrm{~L}^{-1} \mathrm{NaHCO} 3$ in TCM199 supplemented with $10 \%(\mathrm{v} / \mathrm{v})$ fetal calf serum(FCS), $1.5 \mathrm{mg} \mathrm{mL}^{-1}$ porcine FSH-LH (Stimufol; ULg FMV) and $1 \mathrm{mg} \mathrm{mL}^{-1} 17 \beta$-oestradiol. COCs 
were transferred $(n=30-50)$ into a four well dish containing $500 \mathrm{~mL}$ of $\mathrm{MM}$ medium for $22-24 \mathrm{~h}$ at $38.7^{\circ} \mathrm{C}$ in an atmosphere of $5 \% \mathrm{CO}_{2}$ with saturated humidity. After IVM, oocytes were subjected to in vitro fertilization (IVF; Day 0) with sex-sorted or non-sex-sorted spermatozoa following described procedures (Gómez et al. 2008; Trigal et al. 2012a). IVF was performed with commercial frozen-thawed spermatozoa from Holstein or Asturiana de los Valles breeds.

For experiments entirely in vitro, IVF was performed with non-sorted spermatozoa ( $n=6$ bulls), while embryos for transfer to recipients were produced with non-sorted and sex-sorted spermatozoa ( $n=6$ and $n=4$ bulls respectively). COCs were washed twice in $\mathrm{HM}$ and placed in four-well culture dishes containing pre-equilibrated fertilisation medium (Fert-Tyrode's albumin lactate pyruvate, TALP) with $10 \mathrm{mgmL}^{-1}$ heparin (Calbiochem). IVF was accomplished by incubating oocytes and sperm cells together for $18-20 \mathrm{~h}$ at $38.7^{\circ} \mathrm{C}$ in an atmosphere of $5 \% \mathrm{CO}_{2}$ with saturated humidity. Subsequently, cumulus cells were detached using a vortex and presumptive zygotes were cultured in glucose-free, modified synthetic oviduct fluid (mSOF) containing $45 \mu \mathrm{L} \mathrm{mL} \mathrm{L}^{-1}$ amino acids (BME Amino Acid Solution; Sigma) and $5 \mu \mathrm{L} \mathrm{mL}^{-1}$ non-essential amino acid (Minimum Essential Medium Non-Essential Amino Acid Solution; Sigma), 0.34mM tri-sodium-citrate, $2.77 \mathrm{mM}^{\mathrm{m} y o-i n o s i t o l}$ and $6 \mathrm{~g} \mathrm{~L}^{-1}$ BSA (Fraction V, mouse embryo culture tested A-3311) as previously described (Murillo-Ríos et al. 2016). Droplets of mSOF (1-2 mL per embryo) were layered under mineral oil and embryos cultured in groups of 35 to 45 . In vitro culture was carried out at $38.7^{\circ} \mathrm{C}, 5 \% \mathrm{CO}_{2}, 5 \% \mathrm{O}_{2}, 90 \% \mathrm{~N}_{2}$ and saturated humidity. On Day 6 (143 h post-insemination (PI)), good-quality M $(n=858)$ and EB $(n=86)$ were selected and cultured individually for $24 \mathrm{~h}$ in 12-mL drops of mSOF with 
(6mg mL $\left.\mathrm{mL}^{-1} \mathrm{BSA}\right)$ or without protein $\left(0.5 \mathrm{mg} \mathrm{mL}^{-1}\right.$ polyvinyl-alcohol (PVA) was added to replace BSA) under mineral oil. Amino-acid supplements BME and MEM were used throughout. Blastocyst development was monitored on Day 7 (168 h PI and Day 8 (187 h Pl).

\subsubsection{Embryo sexing by PCR}

We analysed embryonic sex as a factor influencing blastocyst development in vitro. The embryonic sex was determined in individually cultured Day-7 XB derived from Day-6 M (M-XB) and Day-6 EB (EB-XB), cultured with and without protein. A built-in control PCR technique based on amelogenin gene amplification (Trigal et al. 2012b) was used. Sex ratio was calculated as a proportion of male to female embryos.

\subsubsection{Vitrification of embryos for transfer}

Vitrification procedures have been previously described in detail (Trigal et al. 2012a). Briefly, Day-7 excellent XB were vitrified in two steps with fibre plugs (CryoLogic Vitrification Method; CVM). Final vitrification solutions contained $16.5 \%$ ethylene glycol, $16.5 \%$ dimethyl sulfoxide (DMSO) and $0.5 \mathrm{M}$ sucrose. Samples were vitrified by touching the surface of a chilled block placed in liquid nitrogen with the hook. Embryos were warmed by directly immersing the fibre plug end in sucrose solution in one step (Caamaño et al. 2015) or in two steps (Trigal et al. 2012a). Subsequently, embryos were washed twice in embryo preservation medium (IMV Technologies) and loaded into straws for transfer. In vitro development of vitrified-warmed embryos cultured with and without protein has already been reported (Murillo-Ríos et al. 2016). 


\subsubsection{Lipid and cell nuclei staining}

Embryos selected were Day-6 morulae and Day-7 excellent- to very-goodquality blastocysts cultured with or without protein that derived from either morulae or early blastocysts. Embryos were fixed in $4 \%$ paraformaldehyde for $20 \mathrm{~min}$ at room temperature and kept in 0.1 Mphosphate-buffered saline (PBS) with $0.1 \mathrm{mg} \mathrm{mL}^{-1}$ polyvinyl alcohol (PBS-PVA; $\left.\mathrm{pH} 7.4,4^{\circ} \mathrm{C}\right)$ overnight. Nile red stock solution was prepared by dissolving $1 \mathrm{mg} \mathrm{mL}^{-1}$ lipid-specific Nile red dye in DMSO, which was stored in the dark. Embryos were washed for 1 min with 400 $\mathrm{mL}$ of $1 \mathrm{mg} \mathrm{mL}^{-1}$ Nile red stock solution in PBS-PVA (based on Ghanem et al. 2014) and then stained for $1 \mathrm{~h}$ in darkness. Embryos were washed again in PBS-PVA and transferred into a 4well dish with $400 \mathrm{~mL}$ 4, 6-diamidino-2phenylindole (DAPI) dye (5 mg mL $\mathrm{mL}^{-1}$ in PBS, 300nM concentration) for 2 min and washed thrice in PBS-PVA. Blastocysts stained only with DAPI were used as negative controls. Finally, embryos were mounted on a slide with Vectashield $\mathrm{H}-1000$ (Vector Laboratories) under a coverslip. Samples stored in the dark at 48C overnight and examined under a confocal microscope (ultra-spectral Leica TCS-SP2-AOBS; Leica Microsystems). The lipophilic fluorescent Nile red dye was excited at $450-500 \mathrm{~nm}$ and DAPI at $421-476 \mathrm{~nm}$. Next, digital pictures of the complete embryo, each $1.5 \mathrm{~mm}$ on the $\mathrm{Z}$ plane, were captured. Imaris 7.1 software (Bitplane Oxford Instruments) was used to generate three dimensional (3D) reconstructions from confocal datasets to assess lipid droplet contents. Lipid droplets $(n)$ were measured in volume mode but arranged by diameter as small $(<2 \mu \mathrm{m})$, medium $(2-6 \mu \mathrm{m})$ and large $(>6 \mu \mathrm{m})$, in order to facilitate comparisons with measurements in diameter from previous work (Abe et al. 2002). 


\subsubsection{RNA analysis}

The expression of genes involved in lipid metabolism was analysed in fresh and vitrified-warmed embryos cultured with and without protein from Day 6 to Day 7 using previously described procedures (Cordova et al. 2014). All embryos used were Day-7 M-XB. Blastocysts were collected from single culture droplets, washed three times in PBS-PVA, snap frozen and kept at $-80^{\circ} \mathrm{C}$ until use. Total RNA was extracted from groups of blastocysts by using TRIzol reagent (Life Technologies). In brief, $300 \mu \mathrm{L}$ of TRIzol was added to each tube with frozen embryos and $1 \mathrm{pg}$ of luciferase RNA per embryo was added to each sample as external RNA control before extraction. Total RNA was then extracted according to the manufacturer's instructions. The total amount of RNA from each sample was subjected to reverse transcription (RT) using iScript cDNA Synthesis Kit (BioRad). Real-time polymerase chain reaction (PCR) was carried out in $20 \mathrm{~mL}$ containing 1 x qPCR Mastermix Plus for SYBR Green I (BioRad), specific primers (see Table 4.1) at a final concentration of $150 \mathrm{nM}$ and $5 \mu \mathrm{L}$ of the RT reactions diluted $1: 20$. Real-time PCR quantification of gene expression was performed using a MyiQ thermocycler (BioRad). RNA extraction efficiency was checked by amplification of Luciferase transcripts and the samples with the lowest expression were removed from the analyses. Primer efficiency and the standard curve for each candidate gene were deduced from serial dilutions of the corresponding cDNA fragment as a template. The geometric mean of housekeeping genes (RPL19 and RPS9) was used to normalise gene expression. The relative amounts of gene transcripts $(R)$ were calculated as $R=$ gene $\mathrm{E}^{-\mathrm{Ct} \text { gene}} /$ geometric mean (RPS9 $\mathrm{E}^{-\mathrm{Ct}} \mathrm{RPS9} ; \mathrm{RPL19} \mathrm{E}^{-\mathrm{Ct} R P L 19}$ ), where $\mathrm{E}$ is PCR efficiency for each pair of primers (Table 4.1) and Ct is a cycle threshold. 
In total, fresh XB ( $n=41$ with protein and $n=39$ without protein) and vitrifiedwarmed hatched blastocysts ( $n=26$ with protein and $n=27$ without protein) were analysed. Normalised mean values of gene expression were analysed separately for protein and no protein within the fresh and vitrified-warmed groups.

Table 4.1. Oligonucleotides used for real-time PCR gene expression 1 analysis

\begin{tabular}{|c|c|c|c|c|c|c|}
\hline Gene & primer & Sequence $5^{\prime}-3^{\prime}$ & Accession & $\begin{array}{l}\text { Amplic } \\
\text { on (bp) }\end{array}$ & Gene product & $\begin{array}{l}\text { Primers' } \\
\text { efficiency } \\
(\%)\end{array}$ \\
\hline ABHD6 & $\begin{array}{l}\text { fw } \\
\text { rev }\end{array}$ & $\begin{array}{l}\text { ACCCCGAAGGAGATGAGTG } \\
\text { A } \\
\text { CTGGGAGTTGGCGATTGAC } \\
\text { T }\end{array}$ & $\begin{array}{l}\text { NM_oo107519 } \\
6\end{array}$ & 276 & $\begin{array}{l}\text { Abhydrolase domain } \\
\text { containing } 6\end{array}$ & 1.93 \\
\hline$A C A C A$ & $\begin{array}{l}\mathrm{fw} \\
\mathrm{rev}\end{array}$ & $\begin{array}{l}\text { TGCTTCCCATTTGCCATC } \\
\text { CTGCCATCCTCACGACCT }\end{array}$ & NM_174224 & 188 & $\begin{array}{l}\text { Acetyl coenzyme A } \\
\text { carboxylase }\end{array}$ & 1.90 \\
\hline$A C T B$ & $\begin{array}{l}\mathrm{fw} \\
\mathrm{rev}\end{array}$ & $\begin{array}{l}\text { GCTGTCCCTGTATGCCTCT } \\
\text { GG } \\
\text { GAACCGCTCATTGCCGATG } \\
\text { G }\end{array}$ & NM_173979 & 349 & Actin, beta & 2.01 \\
\hline $\boldsymbol{B A X}$ & $\begin{array}{l}\text { fw } \\
\text { rev }\end{array}$ & $\begin{array}{l}\text { AGAGGATGATCGCAGCTGT } \\
\text { GGA } \\
\text { CAAAGATGGTCACTGTCTG } \\
\text { CCATGT }\end{array}$ & NM_173894 & 300 & Bcl-2-associated X protein & 1.99 \\
\hline CPT1A & $\begin{array}{l}\mathrm{fw} \\
\mathrm{rev}\end{array}$ & $\begin{array}{l}\text { TCCTGGTGGGCTACCAATT } \\
\text { A } \\
\text { TGCGTCTGTAAAGCAGGAT } \\
\text { G }\end{array}$ & FJ415874 & 181 & $\begin{array}{l}\text { Carnitine } \\
\text { palmitoyltransferase } 1 \mathrm{~A}\end{array}$ & 1.95 \\
\hline CPT2 & $\begin{array}{l}\mathrm{fw} \\
\mathrm{rev}\end{array}$ & $\begin{array}{l}\text { TGTGCCTTCCTTCCTGTCTT } \\
\text { GG } \\
\text { CGATGGGGTCTGGGTAAAC } \\
\text { GA }\end{array}$ & $\begin{array}{l}\text { NM_oo104588 } \\
9\end{array}$ & 111 & $\begin{array}{l}\text { Carnitine } \\
\text { palmitoyltransferase } 2\end{array}$ & 1.98 \\
\hline DGAT1 & $\begin{array}{l}\mathrm{fw} \\
\mathrm{rev}\end{array}$ & $\begin{array}{l}\text { CGCCTTCTTCCACGAGTAC } \\
\text { C } \\
\text { CCGATGATGAGTGACAGCC } \\
\text { A }\end{array}$ & NM_174693 & 159 & $\begin{array}{l}\text { Diacylglycerol O- } \\
\text { acyltransferase } 1\end{array}$ & 1.96 \\
\hline $\mathrm{FABP}_{3}$ & $\begin{array}{l}\text { fw } \\
\text { rev }\end{array}$ & $\begin{array}{l}\text { ATCGTGACGCTGGATGGCG } \\
\text { G } \\
\text { GCCGAGTCCAGGAGTAGCC } \\
\text { CA }\end{array}$ & NM_174313 & 210 & Fatty acid binding protein 3 & 2.04 \\
\hline FABP 5 & $\begin{array}{l}\mathrm{fw} \\
\mathrm{rev}\end{array}$ & $\begin{array}{l}\text { TGGCGCATTGGTTCAACAT } \\
\text { CAGG } \\
\text { TGAACTGAGCTTGTTCATC } \\
\text { CTCGC }\end{array}$ & NM_174315 & 193 & Fatty acid binding protein 5 & 2.03 \\
\hline FASN & $\begin{array}{l}\text { fw } \\
\text { rev }\end{array}$ & $\begin{array}{l}\text { CACTCCATCCTCGCTCTCC } \\
\text { GCCTGTCATCATCTGTCAC } \\
\text { C }\end{array}$ & $\mathrm{AY}_{343889}$ & 181 & Fatty acid synthetase & 2.03 \\
\hline GLUT1 & fw & $\begin{array}{l}\text { CTGATCCTGGGTCGCTTCA } \\
\text { T } \\
\text { ACGTACATGGGCACAAAAC } \\
\text { CA }\end{array}$ & NM_174602 & 68 & $\begin{array}{l}\text { Solute carrier family } 2 \\
\text { (facilitated glucose } \\
\text { transporter), member } 1 \\
\text { (SLC2A1) }\end{array}$ & 2.04 \\
\hline GPX1 & $\begin{array}{l}\text { fw } \\
\text { rev }\end{array}$ & $\begin{array}{l}\text { GCAACCAGTTTGGGCATCA } \\
\text { CTCGCACTTTTCGAAGAGC } \\
\text { ATA }\end{array}$ & NM_174076 & 116 & Glutathione peroxidase 1 & 2.06 \\
\hline $\mathrm{GPX}_{4}$ & $\begin{array}{l}\mathrm{fw} \\
\mathrm{rev}\end{array}$ & $\begin{array}{l}\text { CGATACGCCGAGTGTGGTT } \\
\text { TAC } \\
\text { ACAGCCGTTCTTGTCAATG } \\
\text { AGG }\end{array}$ & NM_174770 & 261 & Glutathione peroxidase 4 & 1.96 \\
\hline LIPE & fw & $\begin{array}{l}\text { GAGTTTGAGCGGATCATTC } \\
\text { A }\end{array}$ & & 102 & Hormone-sensitive lipase & 1.98 \\
\hline
\end{tabular}




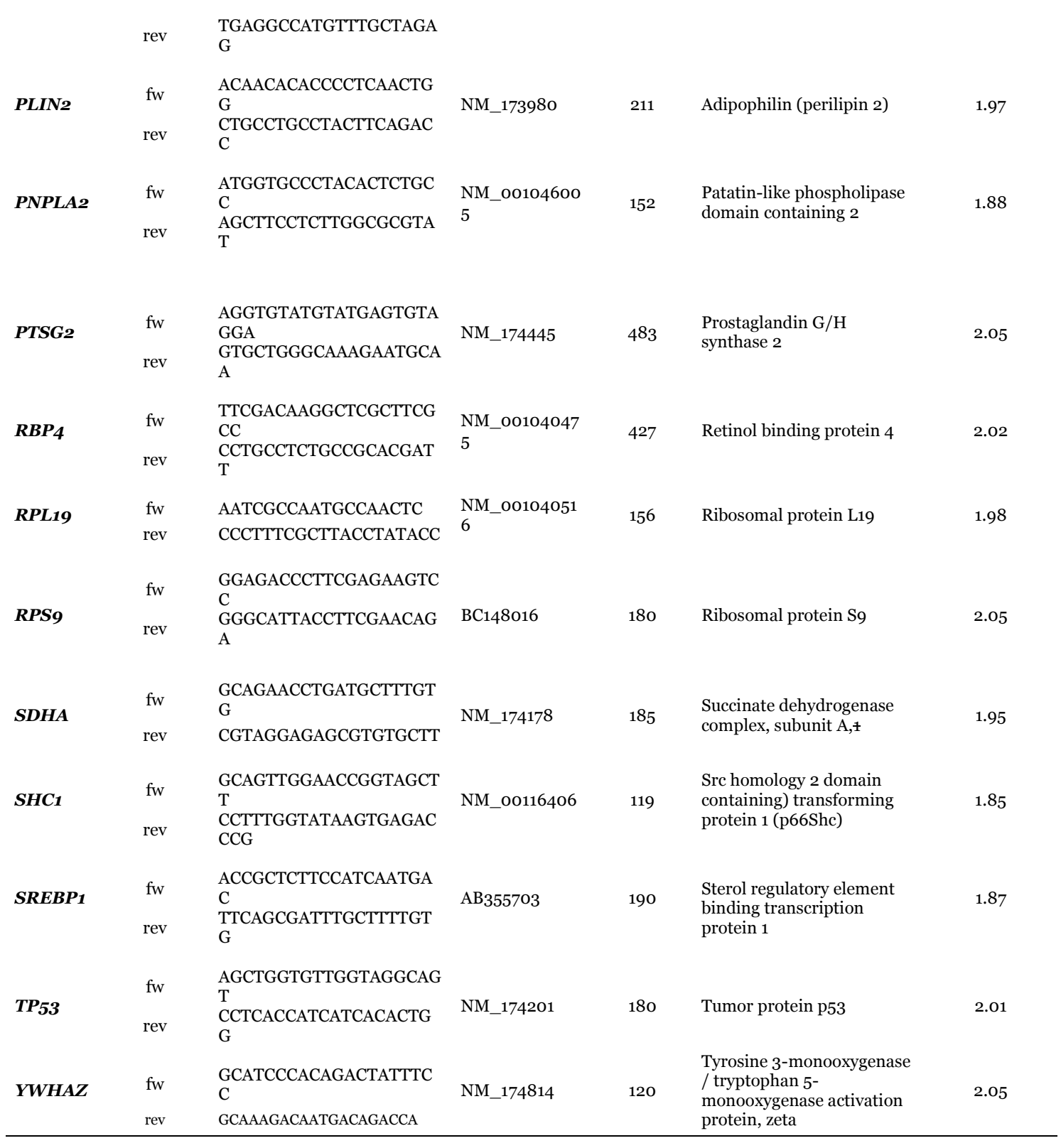

\subsubsection{Embryo transfer, pregnancy diagnosis and calf phenotyping}

Detailed procedures have been described (Hidalgo et al. 2004). Briefly, Holstein and Asturiana de los Valles recipient heifers $(n=63)$ were synchronised in oestrus by using an intra-vaginal progestagen device (PRID Alpha; Ceva Salud Animal) for 10 days combined with a prostaglandin F2 $\alpha$ analogue (Dynolitic, Pfizer,) injected $48 \mathrm{~h}$ before progestagen removal. Prior to transfer, Day-7 XB that had been vitrified at 170-172 h PI were warmed and allowed to re-expand for $1-2 \mathrm{~h}$ in vitro. On Day 7 ( $225 \pm 1.5 \mathrm{~h}$ after progestagen removal; fixed time), 
blastocysts were non-surgically transferred to recipients in the cranial third of the uterine horn ipsilateral to the corpus luteum under epidural anaesthesia. Pregnancy was diagnosed on Day 40 and on Day 62; miscarriages and birth rates were monitored in recipients transferred once or twice. However, bodyweight (BW), height at withers (HW), thorax circumference (TC), gestation length $(G L)$ and daily weight $(B W / G L)$ were recorded at birth in recipients transferred up to four times. Plasma P4 was measured on Day 0 and Day 7 (before embryo transfer) in blood samples taken up into ethylenediamine tetraacetic acid (EDTA) vacuum tubes via coccygeal vein puncture. An enzymelinked immunosorbent assay (ELISA) test operating on a $0-40 \mathrm{ng} \mathrm{mL} \mathrm{m}^{-1}$ scale (DRG Diagnostics) was used. The test was sensitive starting from $0.5 \mathrm{ng} \mathrm{mL} \mathrm{m}^{-1}$ and cross-reactivity from steroids other than P4 was less than $1 \%$. Intra and interassay coefficients of variation were $6 \%$ and $7 \%$ respectively.

\subsubsection{Experimental design}

4.2.7.1. Experiment 1: Day-7 embryo development patterns and sex ratio after individual culture in the presence or absence of protein during $24 \mathrm{~h}$ Blastocyst development was monitored in vitro from morulae $(\mathrm{M})$ and early blastocysts (EB) cultured from Day 6 onwards in individual droplets with and without protein. On Day 7, embryonic sex was determined in expanded blastocysts (XB) derived from Day-6M (M-XB) and Day-6 EB (EB-XB), cultured with and without protein, in order to establish if development patterns influenced embryonic sex ratio.

4.2.7.2. Experiment 2: analysis of gene expression after individual culture in the presence or absence of protein 
Expression of genes involved in lipid metabolism, oxidative stress and apoptosis was analysed in fresh and vitrified-warmed embryos. Because we could not generate a sufficient number of EB-XB blastocysts for this analysis, only M-XB blastocysts were used. Two separate analyses were performed with and without vitrification.

4.2.7.3. Experiment 3: long-term effects of protein removal and development patterns

In vitro embryo production and cryopreservation influence pregnancy rates and calf phenotypes. In this study, we analysed pregnancy rates on Days 40 and 62, birth rates, miscarriage rates from Day 40 onwards and calving weight and other body measurements at birth after transfer of vitrified-warmed embryos on the basis of the presence of protein and embryonic stage on Day 6 . Experiments included both a proportion of re-examined retrospective data (Murillo-Ríos et al. 2016) and new data. Ultimately, in order to demonstrate that pregnancy, birth and calf phenotypes were attributable only to embryo vitrification, we retrospectively analysed an additional dataset of fresh versus vitrified embryo transfers of Day-7 M-XB and EB-XB developed with protein. In those years (2010-2011), the vitrification procedure required multi-step warming; some different bulls were used and no embryo transfers without protein were performed. Therefore, such data were not connected for statistical purposes and are shown separately.

\subsubsection{Statistical analysis}

Data requiring normalisation were arcsine transformed and analysed using the Proc GLM module of SAS/STAT (Version 9.2; SAS Institute Inc.). In 
experiments concerning embryo development, gene expression analysis and lipid granule evaluation, the fixed effects included were presence of protein, embryonic stage on Day 6 (not for gene expression) and replicate. For embryo transfer, pregnancy and birth rates, body measurements and birthweight, the effects included were embryonic stage on Day 6, presence of protein, bull, sexsorted spermatozoa, recipient breed, year and season. Plasma P4 was analysed using year, season and recipient breed, as well as corpus luteum side (Trigal et al. 2014), as fixed effects. Calf body measurements and birthweight also included embryonic sex. Least-squares means and their errors ( \pm s.e.m.) were estimated for each level of fixed effects with a significant F-value. The Ryan-Einot-Gabriel-Welsch Q-test was used to compare the raw means of the levels from the fixed effects $(P<0.05)$.

\subsection{Results}

\subsubsection{Embryo development in individual culture}

This experiment consisted of $n=944$ Day- 6 embryos cultured in 20 replicates. On Day 7, blastocyst formation and expansion rates were higher for Day-6 EB than $\mathrm{M}$, both with and without protein $(\mathrm{P}<0.005$; Table 4.2). Within $\mathrm{M}$, those developed with protein reached total blastocyst rates higher than those in protein free medium (74.5 \pm 2.8 vs. $55.4 \pm 2.5$ respectively; $\mathrm{P}<0.005)$. On Day 8, similar to Day 7, higher expansion rates occurred in EB than in $M(P<0.005)$. Interestingly, hatching rates were significantly increased $(P<0.05)$ in EB cultured with protein, with the remaining groups showing lower and comparable hatching rates. 
Table 4.2. In vitro blastocyst development rates of Day-6 morulae (M) and early blastocysts (EB) cultured individually in $12 \mu \mathrm{L}$ drops of SOF containing amino-acids, citrate and myo-inositol with $\left(+; 6 \mathrm{mg} \mathrm{mL}^{-1} \mathrm{BSA}\right)$ or without (-; $0.5 \mathrm{mg} \mathrm{mL}^{-1}$ PVA replacing BSA) protein up to Day 8

\begin{tabular}{|c|c|c|c|c|c|c|c|}
\hline \multirow[b]{2}{*}{ Protein } & \multirow[b]{2}{*}{ Stage } & \multirow[b]{2}{*}{$n$} & \multicolumn{2}{|c|}{ Day-7 blastocysts (\%) } & \multicolumn{3}{|c|}{ Day-8 blastocysts (\%) } \\
\hline & & & Total & Expanded & Total & Expanded & Hatched \\
\hline$(+)$ & EB & 40 & $98.8 \pm 3.8^{\mathrm{a}}(39)$ & $66.9 \pm 6.2^{\mathrm{a}}(28)$ & $92.8 \pm 5.6^{\mathrm{a}}(36)$ & $86.6 \pm 7.4^{\mathrm{a}}(35)$ & $19.9 \pm 4.6^{\mathrm{a}}(9)$ \\
\hline$(+)$ & $M$ & 400 & $74.5 \pm 2.8^{b}(296)$ & $21.4 \pm 4.6^{\mathrm{b}}(83)$ & $77.5 \pm 4.1(311)$ & $50.1 \pm 5.4^{\mathrm{bc}}(202)$ & $3.0 \pm 3.3^{b}(11)$ \\
\hline$(-)$ & EB & 46 & $95.1 \pm 3.6^{\mathrm{a}}(44)$ & $68.8 \pm 6.0^{\mathrm{a}}(30)$ & $92.2 \pm 5.4^{\mathrm{a}}(42)$ & $68.8 \pm 7.1^{\mathrm{ab}}(32)$ & $5.9 \pm 4.4^{b}(3)$ \\
\hline$(-)$ & M & 458 & $55.4 \pm 2.5^{\mathrm{C}}(255)$ & $9.4 \pm 4.6^{\mathrm{b}}(44)$ & $64.3 \pm 4.1^{\mathrm{b}}(292)$ & $35.0 \pm 5.4^{\mathrm{C}}(161)$ & $2.9 \pm 3.3^{b}(13)$ \\
\hline$P$ value & & & 0.005 & 0.005 & 0.005 & 0.005 & 0.05 \\
\hline
\end{tabular}

$n=$ Day-6 embryos (cultured in 20 replicates). Data expressed as frequency percentages \pm s.e.m. of Day- 6 cultured embryos that reached at least the indicated blastocyst stage ( $\mathrm{n}$ embryos in parentheses). Values in the same column with different superscript letters differ significantly at the indicated levels. 


\subsubsection{Embryonic sex ratio}

Embryonic sex was analysed in Day-7 XB $(n=120$ embryos from six replicates). There were no significant differences in the embryonic sex ratio between $\mathrm{M}-\mathrm{XB}$ and EB-XB cultured with or without protein $(\mathrm{P}>0.05$; Table 4.3). However, there were significantly more female embryos among EB-XB than among $\mathrm{M}-\mathrm{XB}$ (sex ratio: $32.0 \%$ vs. $52.6 \%$ respectively; $\mathrm{P}=0.031$ ).

Table 4.3. Expanded blastocyst sex ratio (percent males) according to their Day-6 origin from the morula or the early blastocyst stages and subsequent individual culture in $12 \mu \mathrm{L}$ drops of SOF with (+; $6 \mathrm{mg} \mathrm{mL}^{-1}$ BSA) or without $\left(-; 0.5 \mathrm{mg} \mathrm{mL}^{-1}\right.$ PVA replacing BSA) protein.

\begin{tabular}{lcc}
\hline Day-6 stage & Protein to Day-7 & \% Males $(\boldsymbol{n}$ males/total) \\
\hline Morula & $(+)$ & $49.1(27 / 55)$ \\
Early blastocyst & $(+)$ & $33.3(5 / 15)$ \\
Morula & $(-)$ & $57.5(23 / 40)$ \\
Early blastocyst & $(-)$ & $30.0(3 / 10)$ \\
Cumulative & & $52.6(50 / 95)^{\mathrm{a}}$ \\
Morula & & $32.0(8 / 25)^{\mathrm{b}}$ \\
Early blastocyst &
\end{tabular}

\subsubsection{Lipid content study}

Lipid droplets were analysed in Day-6 morulae and M-XB and EB-XB cultured with or without protein (total 61 embryos; $n=7$ biological replicates). On a percell basis, $M$ showed a lipid granule load significantly higher than $X B(P<0.001)$, regardless of embryos having been cultured in the presence or absence of protein (Fig. 4.1). Subsequently, the effects of protein and embryonic stages on lipid content and cell count were determined in Day-7 M-XB and EB-XB ( $n=44$ embryos; $n=4$ biological replicates). EB-XB contained more cells than M-XB (113.5 \pm 3.8 and $102.7 \pm 3.4$ respectively; $P=0.03)$. However, cell numbers were similar in the presence and absence of protein in culture $(109.3 \pm 3.9$ and $106.5 \pm 3.4$ respectively). The embryonic stage on Day 6 interacted with the 
protein in affecting total lipid content $(P=0.03$; Fig. 4.2). Thus, $M-X B$ cultured without protein tended to contain fewer lipids than M-XB cultured with protein $(P=0.053)$, whereas the EB-EX lipid droplets were similar in the presence or absence of protein. When lipid granules were arranged by size (Fig. 4.3), embryonic cells in M-XB cultured with protein showed more droplets $<2 \mu \mathrm{m}$ than M-XB cultured without protein and EB-XB cultured with protein $(P<0.03)$, while EB-XB cultured without protein did not differ. Protein showed a significant effect $(P=0.02)$, but embryonic stage did not show an effect. The other sizes of granules (i.e. 2-6 $\mu \mathrm{m}$ and $>6 \mu \mathrm{m}$ ), measured on a stage protein basis, did not differ and are not shown in figures. However, granules 2-6 $\mu \mathrm{m}$ tended to be more abundant in $\mathrm{M}-\mathrm{XB}(22.2 \pm 1.5)$ than $\mathrm{EB}-\mathrm{XB}(17.4 \pm 1.7 ; \mathrm{P}=0.057)$. Fig. 4.4 shows a $3 D$ reconstruction from the confocal datasets that illustrate the lipid droplet distribution (Fig. 4.4a-b) and their size (Fig. 4.4c-e).

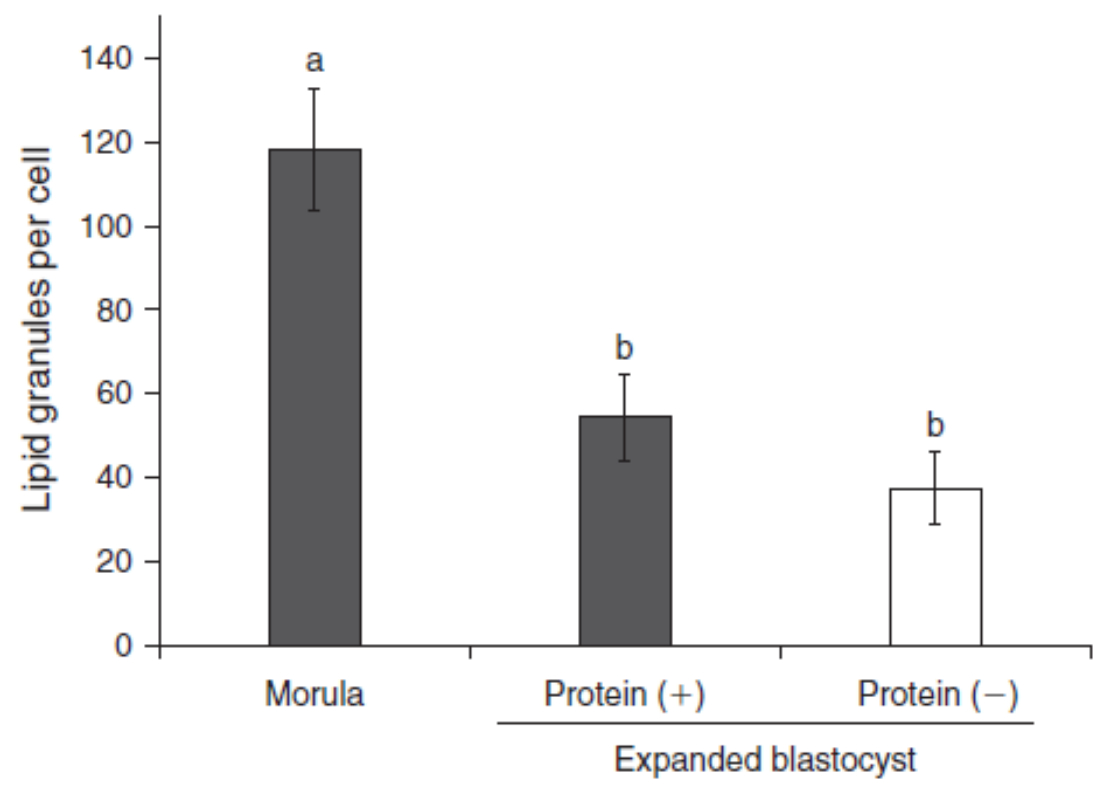

Fig. 4.1. Lipid content per embryonic cell in Day-6 morulae and Day-7 expanded blastocysts cultured with or without protein from Day 6 to Day $7 .{ }^{a, b}$ Different superscript letters denote significant differences $(P<0.001)$. 


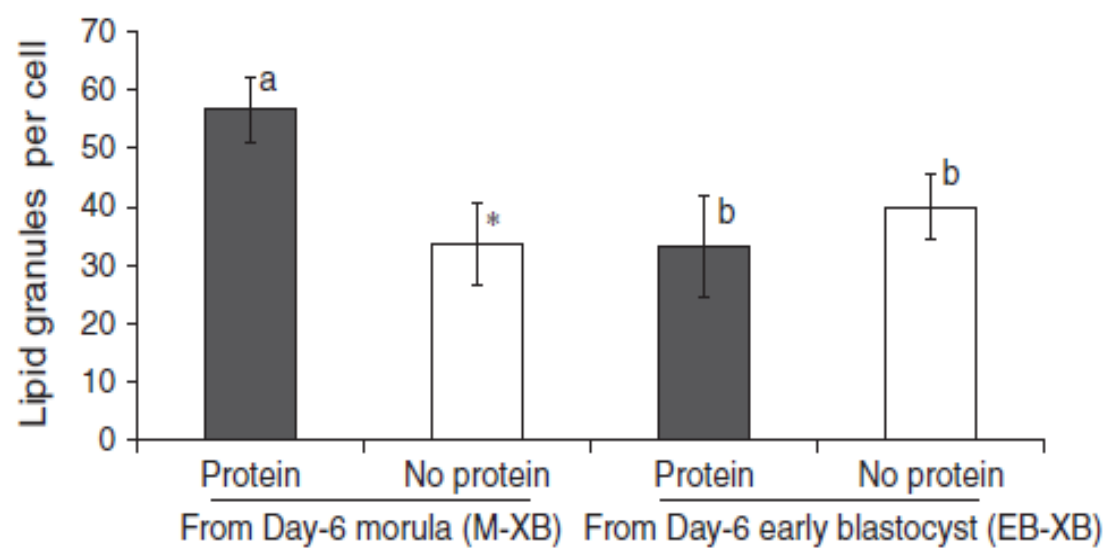

Fig. 4.2. Lipid granules per embryonic cell counted in Day-7 expanded bovine blastocysts following single culture of Day-6 morulae (M-XB) or early blastocysts (EB-XB) in SOF with protein (solid bars; $6 \mathrm{mg} \mathrm{mL}^{-1} \mathrm{BSA}$ ) or without protein (open bars; $0.5 \mathrm{mg} \mathrm{mL}^{-1} \mathrm{PVA}$ ). ${ }^{\mathrm{a}, \mathrm{b}}$ Different superscript letters denote significant differences $(P<0.05)$ or a tendency $\left(a,{ }^{*}: P<0.053\right)$.

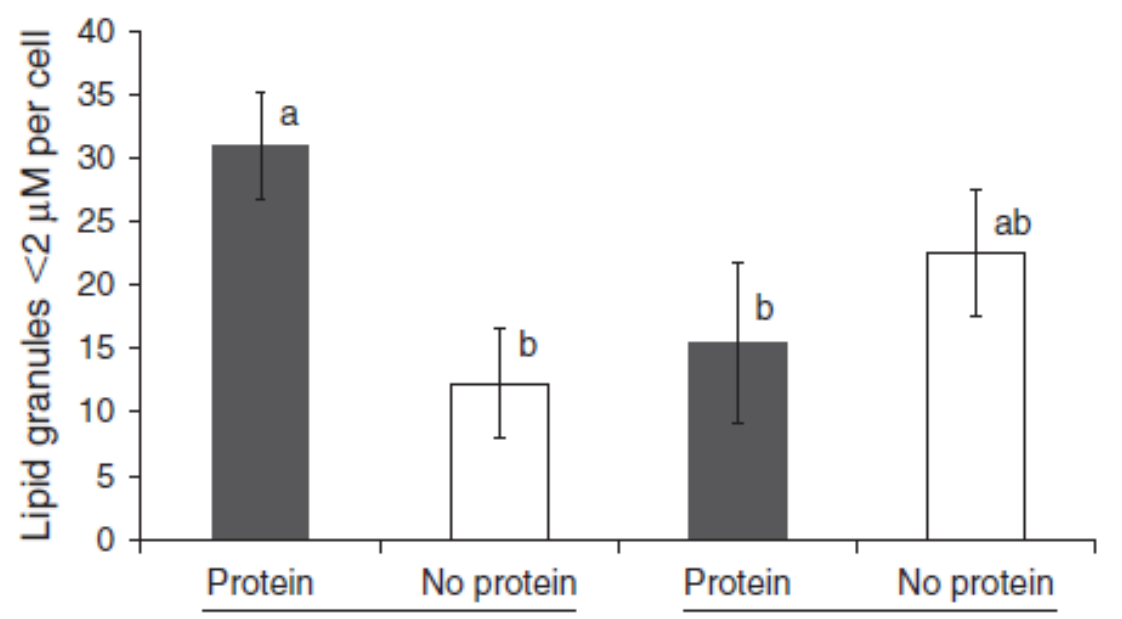

From Day-6 morula (M-XB) From Day-6 early blastocyst (EB-XB)

Fig. 4.3. Average cell abundance of lipid droplets $<2 \mu \mathrm{m}$ in diameter in Day-7 expanded bovine blastocysts following single culture of Day- 6 morulae (M-XB) or early blastocysts (EB-XB) in SOF with protein (solid bars; $6 \mathrm{mg} \mathrm{mL}^{-1} \mathrm{BSA}$ ) or without protein (open bars; $0.5 \mathrm{mg} \mathrm{mL}^{-1} \mathrm{PVA}$ ). ${ }^{a, b}$ Different superscript letters denote significant differences $(P<0.03)$. 

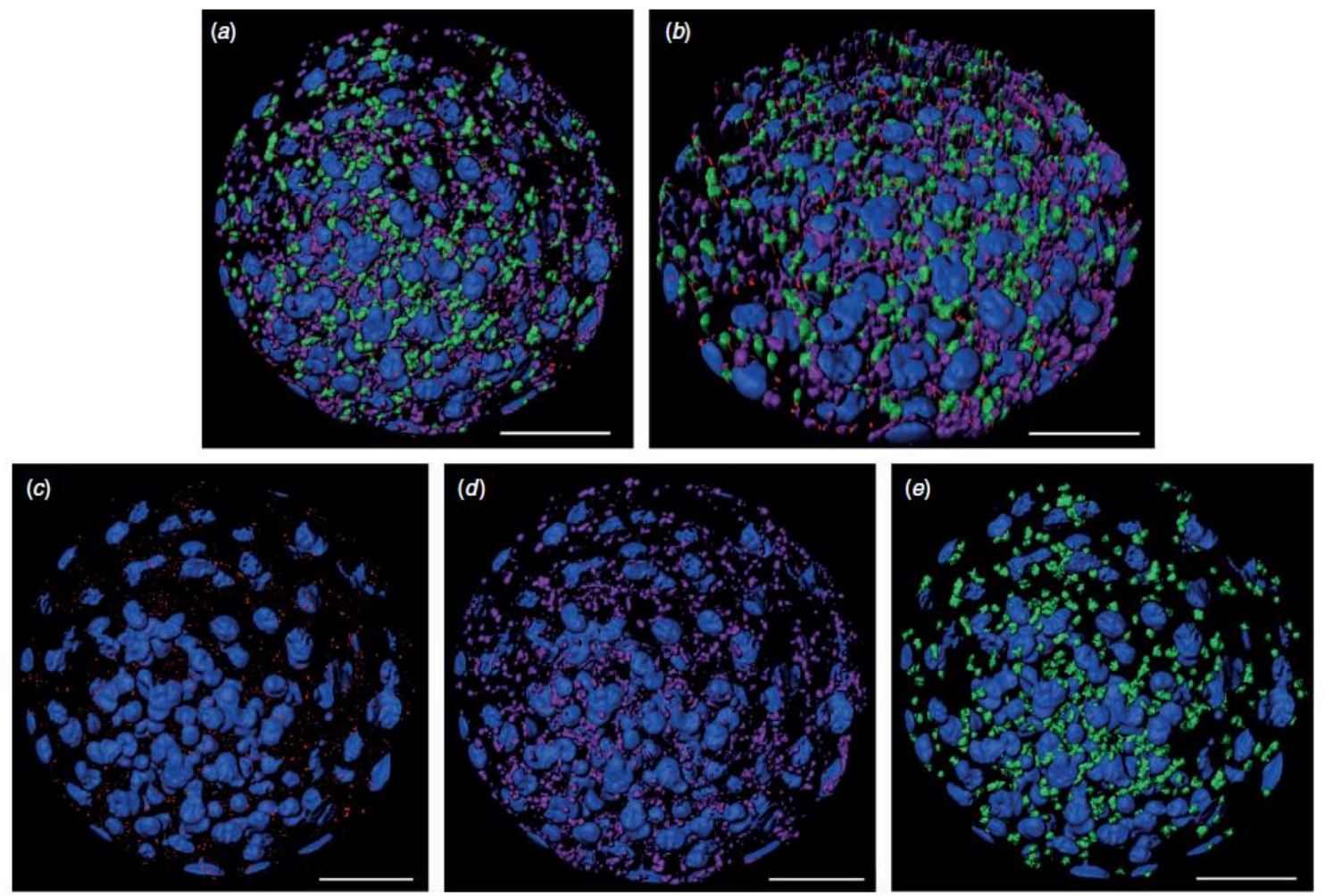

Fig. 4.4. Representative three-dimensional reconstructions of confocal datasets showing lipid droplets stained with Nile red in a Day-7 bovine expanded blastocyst. Lipid droplets have been pseudocoloured according to their size: $<2 \mu \mathrm{m}$ (red), 2-6 $\mu \mathrm{m}$ (purple), $>6 \mu \mathrm{m}$ (green). Lipid droplets are visualised concurrently ( $a$, frontal view; $b$, oblique view) or $(c-e)$ partitioned by size. Nuclei were counterstained with DAPI (blue). Scale bars $=50 \mu \mathrm{m}$.

\subsubsection{Gene expression study}

The effects of the presence of protein from Day 6 to Day 7 of in vitro embryo development on lipid metabolism-related gene expression were analysed in Day-7 M-XB before and after vitrification and warming (as hatched embryos).

Studies with fresh $\mathrm{XB}$ consisted of $n=83$ embryos and six replicates and studies with vitrified-warmed hatched embryos consisted of $n=53$ embryos in five replicates. We compared the relative expression of genes involved in FA synthesis (acetyl coenzyme A carboxylase (ACACA) and fatty acid synthetase (FASM), lipid storage (adipophilin (perilipin 2) (PLIN2) and diacylglycerol Oacyltransferase (DGAT)), FA transport (fatty acid binding protein 3 (FABP3) and fatty acid binding protein 5 (FABP5)), lipolysis (lipases hormone-sensitive lipase 
(LIPE), patatin-like phospholipase domain containing (PLPLA), ABHD6) and mitochondrial b-oxidation (CPT1A, CPT2). Most of these genes were similarly expressed in Day 7 fresh embryos cultured with and without protein, as shown in Fig. 4.5. However, sterol regulatory element binding protein (SREBP1), a transcription factor regulating FA metabolism, showed reduced expression in the presence of protein $(P<0.05)$. In contrast, the lipolysis-related genes PLPLA and LIPE were 2 -fold more abundant in the presence of protein $(P<0.05)$. Genes encoding glutathione peroxidases 1 and 4 did not differ, but glutathione peroxidase 1(GPX1) expression tended to increase $(P<0.08)$ in fresh embryos cultured with protein (Fig. 6). No differences were detected in the expression of solute carrier family 2 (facilitated glucose transporter), member 1 (SLC2A1 or GLUT1; involved in glucose transport), prostaglandin G/H synthase 2 (PTGS2; responsible for prostaglandin synthesis) or in the house-keeping genes actin, beta $(A C T B)$, tryptophan 5-monooxygenase activation protein, zeta (YWHAZ) and Succinate dehydrogenase complex, subunit $A(S H D A)$. Protein in culture triggered overexpression of the pro-apoptotic gene $\mathrm{Bcl}-2-$ associated $X$ protein $(B A X)$ (Fig. 4.6). After vitrification and warming, no significant differences were found in hatched blastocysts cultured with or without protein. 


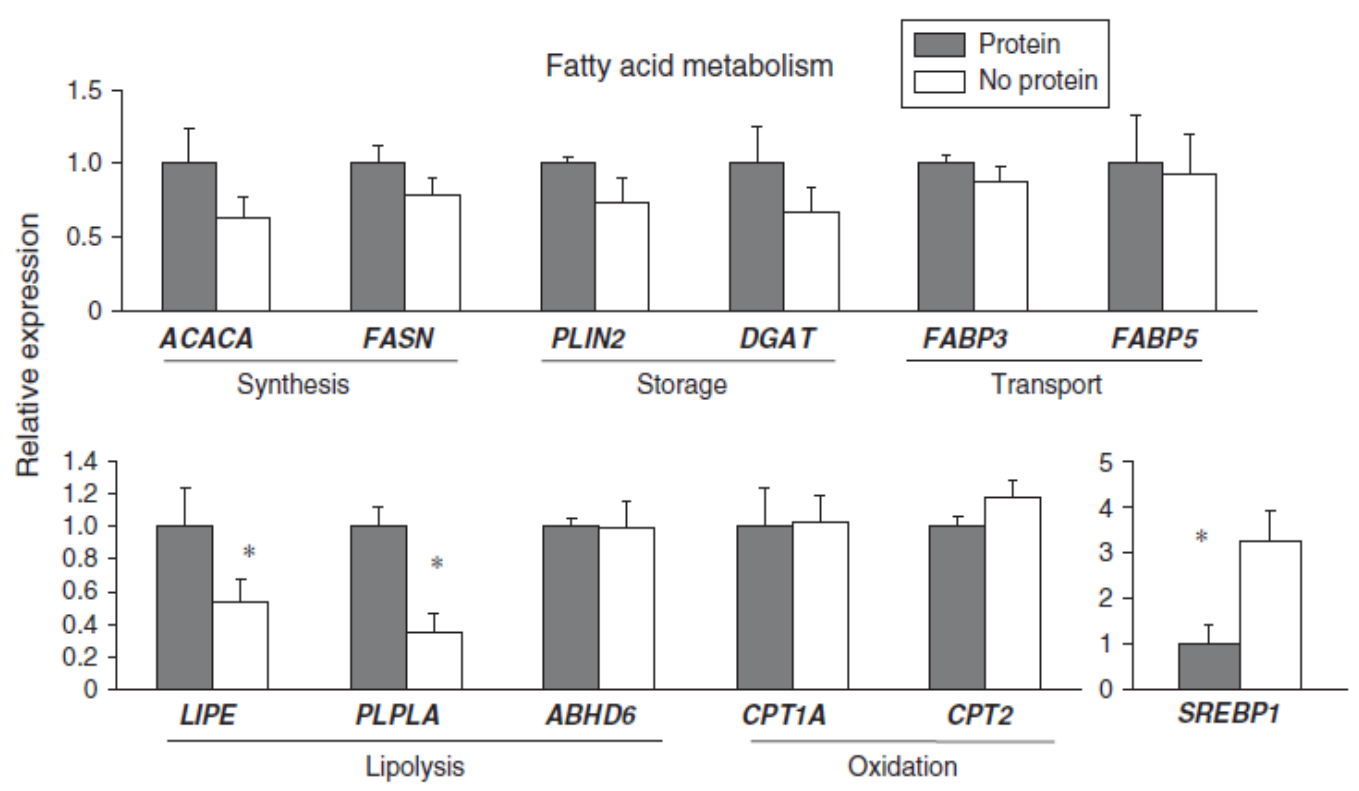

Fig. 4.5. Real-time PCR quantification of relative abundance of transcripts from genes involved in lipid fatty-acid metabolism in Day-7 fresh expanded blastocysts derived from Day-6 morulae (M-XB) cultured for $24 \mathrm{~h}$ with (solid bars) or without (open bars) protein. *Asterisks denote significant differences $(P<0.05)$.

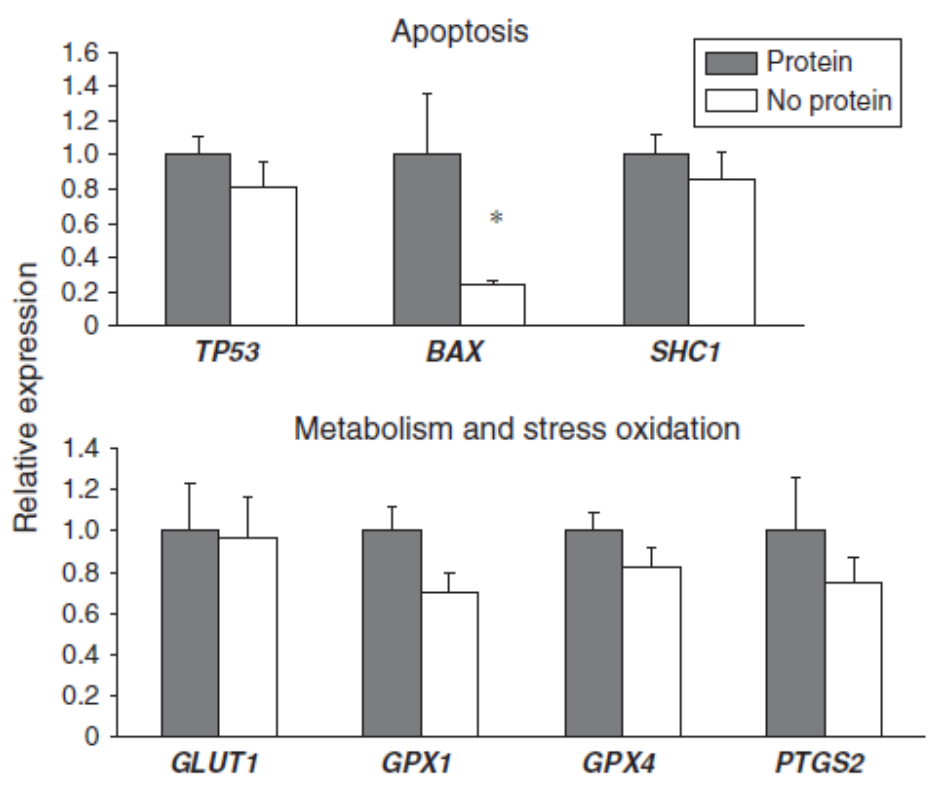

Fig. 4.6. Real-time PCR quantification of relative abundance of transcripts from genes involved in metabolism, lipid oxidative metabolism, antioxidative and stress defence and apoptosis in Day-7 fresh expanded blastocysts derived from Day-6 morulae (M-XB) cultured for $24 \mathrm{~h}$ with (solid bars) or without (open bars) protein. *Asterisks denote significant differences $(P<0.05)$. 


\subsubsection{Embryo transfer, pregnancy, birth and calf phenotypes}

Vitrified-warmed Day-7 M-XB and EB-XB, cultured with or without protein, were transferred to recipients (Table 4.4). Plasma P4 concentration increments did not change between pregnant and open recipients according to the embryonic development pattern (i.e. M-XB or EB-XB; Table 4.5) or protein in culture (Table 4.6).

Table 4.4. Pregnancy, calving and miscarriage rates after transfer of bovine vitrified Day7 expanded blastocysts in terms of their Day- 6 origin from the morula or the early blastocyst stage and subsequent individual culture in $12-\mu \mathrm{L}$ drops of SOF with $(+; 6 \mathrm{mg}$ $\left.\mathrm{mL}^{-1} \mathrm{BSA}\right)$ or without $\left(-; 0.5 \mathrm{mg} \mathrm{mL}^{-1}\right.$ PVA replacing BSA) protein

\begin{tabular}{lcrrrr}
\hline $\begin{array}{l}\text { Day-6 } \\
\text { stage }\end{array}$ & $\begin{array}{c}\text { Protein } \\
\text { to Day 7 }\end{array}$ & \multicolumn{2}{c}{ Pregnancy rate (\%) } & Birth & $\begin{array}{c}\text { Miscarriage From } \\
\text { Day-40 (\%) }\end{array}$ \\
\hline Morula & \multicolumn{7}{c}{ Day 40 } & \multicolumn{1}{c}{ Day 60 } & & \\
Blastocyst & $(+)$ & $16 / 36(44)$ & $15 / 36(42)$ & $9 / 35(26)$ & $6 / 15(40)$ \\
Morula & $(-)$ & $7 / 12(58)$ & $7 / 12(58)$ & $6 / 12(50)$ & $1 / 7(14)$ \\
Blastocyst & $(-)$ & $14 / 22(64)$ & $13 / 22(59)$ & $11 / 20(55)$ & $2 / 13(15)$ \\
\hline Pregn & $9 / 20(45)$ & $8 / 20(40)$ & $6 / 14(43)$ & $0 / 6(0)$ \\
\hline
\end{tabular}

Pregnancy and birth rates expressed as \% ( $\mathrm{n}$ pregnant $\mathrm{n}$ transferred at each specific endpoint; i.e. some pregnancies were in course). Miscarriage rates include premature stillbirth and are calculated only with those Day-40 pregnancies that did or should have reached term

Table 4.5. Progesterone increases from Day-0 up to Day-7 in recipients transferred with Day-7 expanded blastocysts in terms of their Day- 6 origin from the morula or the early blastocyst stage and their pregnancy status on Day-40

\begin{tabular}{lccc}
\hline Day-6 stage & Pregnant & $\boldsymbol{n}$ & P4 [Day-7] - [Day-0] \\
\hline Early blastocyst & $(+)$ & 13 & $15.3 \pm 3.5$ \\
Early blastocyst & $(-)$ & 14 & $12.5 \pm 3.0$ \\
Morula & $(+)$ & 27 & $17.1 \pm 2.1$ \\
Morula & $(-)$ & 27 & $18.8 \pm 2.7$ \\
\hline Differences were not significant $(P>0.10)$ & &
\end{tabular}

Table 4.6. Progesterone increases from Day-0 up to Day-7 in recipients transferred with Day-7 expanded blastocysts in terms their culture with or without protein from Day-6 onwards and their pregnancy status on Day-40

\begin{tabular}{lccc}
\hline Day-6 culture & Pregnant & $\boldsymbol{n}$ & P4 [Day-7] - [Day-0] \\
\hline Protein & $(+)$ & 22 & $18.4 \pm 3.0$ \\
Protein & $(-)$ & 26 & $14.7 \pm 2.6$ \\
No protein & $(+)$ & 18 & $14.7 \pm 2.7$ \\
No protein & $(-)$ & 15 & $16.5 \pm 2.9$ \\
\hline Differences were not significant $(\mathrm{P}>0.10)$ & & &
\end{tabular}


Interaction between Day-6 stages and protein did not affect pregnancy or birth rates ( $P>0.05$; Table 4.4). Miscarriage rates after Day 40 were not significantly affected $(P>0.10)$, although $\mathrm{M}-\mathrm{XB}$ cultured with protein registered numerically higher pregnancy losses. At birth, bodyweight, height at withers, thorax circumference, gestation length and average daily gain weight were not significantly affected by the interaction between stage and protein $(P>0.05$; data not shown). However, calves from $M-X B$ showed significant increases in bodyweight and average daily gain weight $(P>0.01)$ over calves that were EB$\mathrm{XB}\left(48.6 \pm 3.4 \mathrm{~kg}\right.$ and $172 \pm 11 \mathrm{~g} \mathrm{day}^{-1} \mathrm{vs} .39 .8 \pm 2.9 \mathrm{~kg}$ and $140 \pm 9 \mathrm{~g} \mathrm{day}^{-1}$ respectively; Table 4.7).

Table 4.7. Weight and morphometry of calves born after transfer of bovine vitrifiedwarmed Day-7 expanded blastocysts in terms of their Day-6 origin from the morula or the early blastocyst stage

\begin{tabular}{lcccccc}
\hline $\begin{array}{l}\text { Day-6 } \\
\text { Stage }\end{array}$ & $\boldsymbol{n}$ & $\begin{array}{c}\text { BW } \\
\mathbf{( K g )}\end{array}$ & $\begin{array}{c}\text { HW } \\
\mathbf{( c m )}\end{array}$ & $\begin{array}{c}\text { TC } \\
(\mathbf{c m})\end{array}$ & $\begin{array}{c}\text { GL } \\
\text { (days) }\end{array}$ & $\begin{array}{c}\text { DG } \\
\text { (g day }^{-1} \text { ) }\end{array}$ \\
\hline Blastocyst & 12 & $39.8 \pm 2.9^{\mathrm{a}}$ & $78.9 \pm 3.5$ & $80.6 \pm 2.3$ & $281.7 \pm 2.3$ & $140 \pm 9^{\mathrm{a}}$ \\
Morula & 21 & $48.6 \pm 3.4^{\mathrm{b}}$ & $83.0 \pm 3.9$ & $84.6 \pm 2.6$ & $281.2 \pm 2.7$ & $172 \pm 11^{\mathrm{b}}$ \\
\hline
\end{tabular}

Bodyweight (BW), height at withers (HW), thorax circumference (TC), gestation length (GL) and average daily weight gain (DG) of the fetus. Data are LSM \pm s.e.m. ${ }^{a, b}$ Values in the same column with different superscript letters differ significantly $(P<0.01)$

Table 4.8. Weight and morphometry of female calves born after transfer of bovine vitrified-warmed Day-7 expanded blastocysts according to their Day- 6 origin from the morula or the early blastocyst stage

\begin{tabular}{lcccccc}
\hline $\begin{array}{l}\text { Day-6 } \\
\text { stage }\end{array}$ & $\boldsymbol{n}$ & $\begin{array}{c}\text { BW } \\
(\mathbf{K g})\end{array}$ & $\begin{array}{c}\text { HW } \\
(\mathbf{c m})\end{array}$ & $\begin{array}{c}\text { TC } \\
(\mathbf{c m})\end{array}$ & $\begin{array}{c}\text { GL } \\
(\text { days })\end{array}$ & $\begin{array}{c}\text { DG } \\
\text { (g day }^{-1} \text { ) }\end{array}$ \\
\hline Blastocyst & 9 & $38.8 \pm 2.2^{\mathrm{a}}$ & $72.9 \pm 2.9$ & $77.7 \pm 1.9$ & $284.4 \pm 2.6$ & $135 \pm 7^{\mathrm{a}}$ \\
Morula & 17 & $49.5 \pm 2.3^{\mathrm{b}}$ & $78.6 \pm 2.9$ & $82.3 \pm 2.0$ & $285.1 \pm 2.6$ & $173 \pm 7^{\mathrm{b}}$ \\
\hline
\end{tabular}

Bodyweight (BW), height at withers (HW), thorax circumference (TC), gestation length (GL) and average daily weight gain (DG) of the fetus. Data are LSM \pm s.e.m. ${ }^{a, b}$ Values in the same column with different superscript letters differ significantly $(P<0.001)$

When analysis included only female calves, $M$ and EB stage effects on birthweight and average daily gain weight were strikingly more pronounced 
$(P<0.001 ;$ Table 4.8). Fig. 4.7 shows plotted birthweights per bull, sex and embryonic stage arising from vitrified embryos.

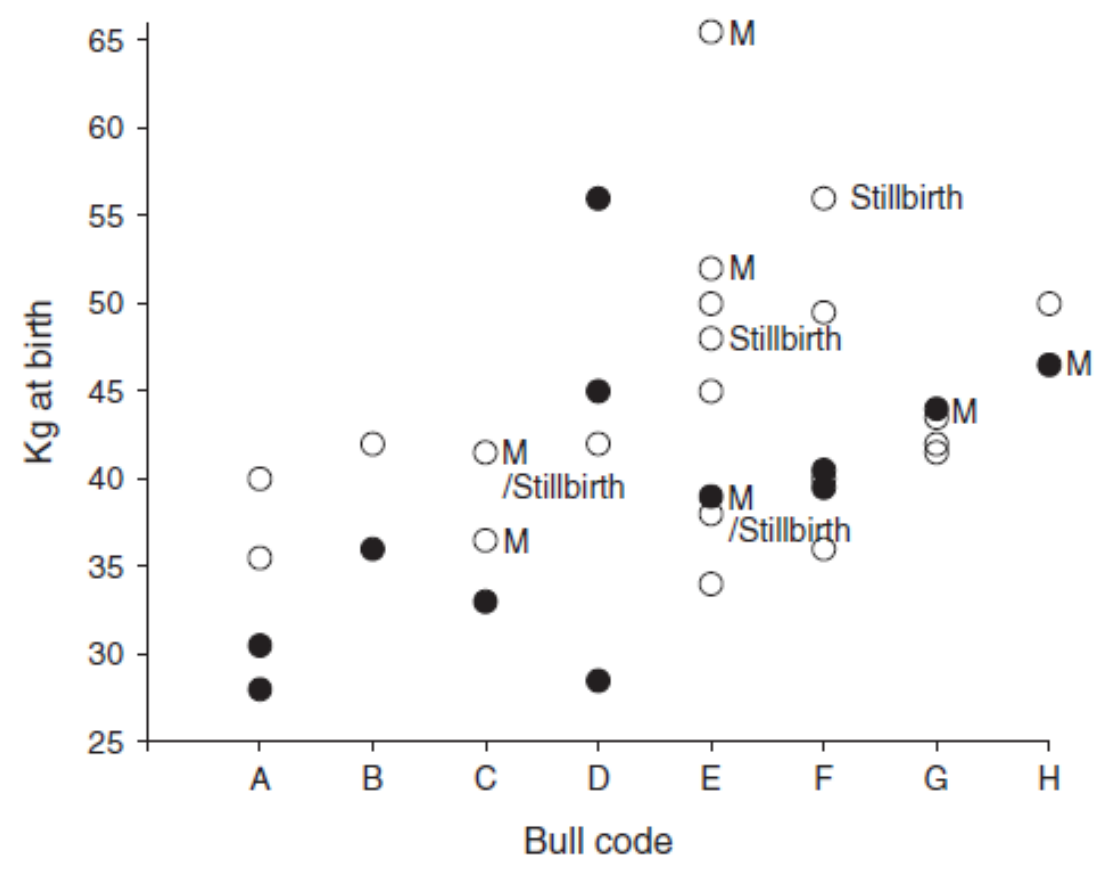

Fig. 4.7. Birthweight on a per bull ( $A$ to $H$ ) basis of calves born after transfer of Day-7 IVP vitrified-warmed embryos whose development stages on Day 6 were monitored as compact morulae (M-XB; open circles) or early blastocysts (EB-XB; solid circles). Males are shown as ' $\mathrm{M}$ '; the remainder are females.

Subsequently, we retrospectively analysed birth data of fresh versus vitrifiedwarmed embryos cultured only with protein (Table 4.9). Calves born from vitrified embryos showed a pronounced tendency to differ $(P<0.06)$ in birthweight and average daily gain weight between M-XB and EB-XB (44.8 \pm $2 \mathrm{~kg}$ vs. $38.1 \pm 2.4 \mathrm{~kg}$, respectively). In contrast, fresh embryos did not show these tendencies $(40.0 \pm 2.3 \mathrm{~kg}$ vs. $43.2 \pm 3.2 \mathrm{~kg}$ for $\mathrm{M}-\mathrm{XB}$ and $\mathrm{EB}-\mathrm{XB}$ respectively; $P>0.05)$. Gestation was shorter in vitrified compared with fresh embryos ( $278.7 \pm 2.1$ days vs. $286.8 \pm 2.3$ days; $P<0.03$ ) 
Table 4.9. Weight and morphometry of calves born after transfer of bovine fresh vs. vitrified/warmed Day-7 expanded blastocysts in terms of their Day- 6 origin from the morula or the early blastocyst stage and subsequent individual culture in 12- $\mu \mathrm{L}$ of SOF containing protein $\left(6 \mathrm{mg} \mathrm{mL}^{-1} \mathrm{BSA}\right)$

\begin{tabular}{llcccccc}
\hline $\begin{array}{l}\text { Day-6 } \\
\text { stage }\end{array}$ & $\begin{array}{l}\text { Day-7 } \\
\text { vitrification }\end{array}$ & $\boldsymbol{n}$ & $\begin{array}{c}\text { BW } \\
\mathbf{( K g )}\end{array}$ & $\begin{array}{c}\text { HW } \\
\mathbf{( c m )}\end{array}$ & $\begin{array}{c}\text { TC } \\
(\mathbf{c m})\end{array}$ & $\begin{array}{c}\text { GL } \\
(\text { days })\end{array}$ & $\begin{array}{c}\text { DG } \\
\text { (g/day) }\end{array}$ \\
\hline Blastocyst & Vitrified & 5 & $38.1 \pm 2.4^{\mathrm{a}}$ & $72.2 \pm 2.5$ & $80.1 \pm 2.0$ & $279.0 \pm 2.7$ & $136 \pm 8^{\mathrm{a}}$ \\
Morula & Vitrified & 11 & $44.8 \pm 2.0^{\mathrm{b}}$ & $75.6 \pm 1.8$ & $82.6 \pm 1.5$ & $278.4 \pm 2.3$ & $160 \pm 7^{\mathrm{b}}$ \\
Blastocyst & Fresh & 6 & $43.2 \pm 3.2$ & $73.1 \pm 3.7$ & $84.1 \pm 2.9$ & $287.2 \pm 3.7$ & $151 \pm 11$ \\
Morula & Fresh & 13 & $40.0 \pm 2.3$ & $74.3 \pm 2.3$ & $80.6 \pm 1.8$ & $285.3 \pm 2.6$ & $140 \pm 8$ \\
\hline
\end{tabular}

Bodyweight (BW), height at withers (HW), thorax circumference (TC), gestation length (GL) and average daily weight gain (DG) of the fetus. Calves born to recipients transferred one to four times. Data are LSM \pm s.e.m. ${ }^{a, b}$ Values in the same column with different superscript letters denote a tendency $(P<0.06)$

\subsection{Discussion}

We describe here how embryo development patterns in the presence or absence of protein entail short- and long-term effects after transfer of vitrifiedwarmed bovine embryos. In cattle in vitro embryo production, post-compaction stages require more protein (Thompson et al. 1998) and amino acids (Guerif et al. 2013) to develop than cleavage stages. In this study protein withdrawal reduced blastocysts rates from the Day- $6 \mathrm{M}$ stage but not from the EB stage. However, amino-acid metabolism of embryos that transit from the $M$ to the EB stage is less active than in embryos that progress from the EB to the XB stage (Guerif et al. 2013). Therefore, the different effects of protein restriction on Day6 stages could not be explained only on the basis of amino-acid shortage. Perhaps protein restriction affects compaction without interfering with later events such as cavitation and blastocyst expansion, since disruption of genes involved in compaction interferes with blastocyst formation (Barcroft et al. 2004). In this study we observed higher rates of female embryos within EB-XB compared with $\mathrm{M}-\mathrm{XB}$. In cattle, when no previous development pattern is considered, more males appear among the faster-developing blastocysts than 
females (Gutiérrez-Adán et al. 1996; Larson et al. 2001; Kimura et al. 2005), although a 24-h individual embryo culture in mSOF with protein did not skew overall blastocyst sex ratio (Muñoz et al. 2014a, 2014b). Discrepancies could be explained by reduced proportions of EB among Day- 6 embryos ( $\approx 10 \%)$, as sex ratio is influenced in only a minimum, unnoticed number of the embryos. Interestingly, the sex effects we observed were clearly stage-associated effects and protein did not exert any influence, in spite of male and female embryos differing in amino-acid metabolism (Sturmey et al. 2010) and in the regulation of protein in uterine fluid (Gómez et al. 2013). In addition, morulae and blastocysts differ in the numbers of expressed sex-linked genes and such differences increase as the embryo develops to the blastocyst stage (Denicol et al. 2015). Protein in culture changed lipid content in XB emerging from Day-6M and EB. Embryonic cells in $\mathrm{M}$ contain more lipid granules than in EBs (Sudano et al. 2016). Furthermore, protein removal increased the reduction in lipid content in the transition from the $M$ to the $X B$ stage, as shown in the pig blastocyst (Romek et al. 2011). However, lipid stocks were reduced in EB-XB, regardless of the presence or absence of protein. Therefore, both exogenous protein and Day-6 embryonic stage (i.e. $M$ or EB) affected lipid content observed at the Day-7 XB stage. It must be considered that our protein supplement may contain FA and the albumin-bound FA fraction may actively incorporate FA into the embryonic cells (Hughes et al. 2011).

Expression patterns of lipid metabolism and oxidative stress response markedly contrast between blastocysts generated in vivo and in vitro (Rizos et al. 2002; González-Serrano et al. 2013; Sudano et al. 2014), which highlights the importance of lipid regulation for embryo quality. Within fresh blastocysts, the 
changes in gene expression from the absence of protein were circumscribed to lipid breakdown and apoptosis. The sterol regulatory element binding protein (SREBP1) was overexpressed in fresh M-XB cultured without protein. SREBP1 activates genes encoding enzymes of cholesterol and FA biosynthesis when intracellular sterol levels are low. Typically, upregulation of SREBP1 occurs in embryos cultured in vitro over in vivo-collected embryos (Driver et al. 2012; González-Serrano et al. 2013). However, free, exogenous and endogenous FA activates SREBP1 in the blastocyst (AI Darwich et al. 2010; González-Serrano et al. 2013), by which increased free FA derived from lipid breakdown in embryos cultured without protein would activate SREBP1. The decrease in the lipolytic genes PLPLA and LIPE can also be explained as being subsequent to a lipid breakdown. In the cow, LIPE is expressed during mobilisation of body fat reserves (Elis et al. 2013). Differences in the size of lipid granules in bovine IVP embryos were previously described (Abe et al. 2002; Barceló-Fimbres and Seidel 2011). Lipogenesis is associated with the smallest granules, which converge to form larger ones by different mechanisms (Thiam et al. 2013). Thus, M-XB without protein showed fewer small and total lipid granules than $\mathrm{M}$ $\mathrm{XB}$ with protein, suggesting that protein removal led to lipid breakdown. Consistent with our previous observations (Murillo-Ríos et al. 2016), BAX expression was reduced in embryos cultured without protein. Within bovine embryos, $B A X$ overexpression is associated with lower-quality embryos (Vandaele et al. 2008). In any case, reduced lipid content, lipid mobilisation and improved survival after cryopreservation accompanied a low apoptotic index in bovine embryos (Ghanem et al. 2014). 
Specific traits of gene expression shown by fresh embryos disappeared in hatched blastocysts that survived vitrification. We have previously observed that vitrification suppresses differences in gene expression after thawing (MurilloRíos et al. 2016). Excess of intracellular lipid increases embryo sensitivity to oxidative stress, chilling and cryopreservation (Abe et al. 2002; Reis et al. 2003; Sudano et al. 2011), by which lipid mobilisation would be a pre-requisite for fresh IVP bovine embryos to survive cryopreservation better (Sanches et al. 2013; Takahashi et al. 2013; Ghanem et al. 2014). Development patterns to the $\mathrm{XB}$ stage and vitrification-warming had long-term consequences. Differences in lipid stocks and lipid metabolism between $\mathrm{M}$ and EB might be the partially underlying cause of the traits we observed in vitrified embryos during in utero development. In this study, although differences in miscarriage rates were not significant, $\mathrm{M}-\mathrm{XB}$ with protein had the highest lipid content and number of miscarriages, which is worthy of further research.

Birthweight was affected by embryo development patterns within vitrifiedwarmed embryos. Calves, particularly females, arising from M-XB were heavier and showed higher daily weight gain than EB-XB. Females were highly represented in our sample set because of the use of female sex-sorted spermatozoa for IVF. The variety of bulls used, with only one out of eight bulls showing discrepant results, and the fact that pregnancies were allowed to reach term naturally, without birth induction, probably reflects the effects of treatments on birth phenotypes better. Birthweight was not directly affected by protein restriction. In vivo, mammalian mothers fed low-energy and low-protein diets can compensate for this restriction in the uterine interface (Spiegler et al. 2014) with no birthweight effects. However, birthweight of rats and mice can be 
affected by low-protein diets administered early in development (Fleming et al. 2015). Gestation length was longer for cows receiving a fresh embryo than for cows receiving a vitrified-warmed embryo, contrasting with the information given by Bonilla et al. (2014). However, in our work, vitrification only affected birthweight on a Day-6 embryonic stage basis, which contrasts with the work carried out by Bonilla et al. (2014), who reported a trend to increased birthweight in female calves from vitrified embryos. Our study indicated that EB showed lower substrate requirement than $\mathrm{M}$ for developing to the $\mathrm{XB}$ stage. The turnover in metabolite uptake and substrate production is lower in more competent embryos (Leese et al. 2008). The amino acid extra load represented by the protein in culture does not seem to be required by the EB-XB, which mobilised their lipids without protein deprivation. These traits favoured reduction in birthweight after vitrification. The link between embryonic stages, birthweight and vitrification was demonstrated with several bulls and both one-step and two-step vitrification, as well as the absence of effects in fresh embryos. Male calves can express birthweight changes within IVP embryos better (Camargo et al. 2010) and we obtained clear differences among female calves. However, caution is necessary, as the number of male calves obtained is not large enough to determine a possible sex effect on birthweight. Vitrified-warmed embryos show extended damage in inner cell mass (ICM) cells (Gómez et al. 2009). The birthweight of calves is positively correlated with placental weight and cotyledonary size and weight (Sullivan et al. 2009). In our study, cell damage in the ICM or trophectoderm (TE) of EB-XB and $M-X B$ surviving vitrification was not assessed. Consequently, possible involvement of vitrification in placenta formation, capable of explaining birthweight differences, 
remains unknown. The P4 increase measured did not vary with development patterns in vitrified embryos and pregnancy.

Improvements in IVP require also carrying pregnancies to term and exploring the health of the offspring. Short-term, individual culture offers biotechnological advantages. In the case of no recipients available or embryo surplus, EBs can be assigned to protein deprivation and vitrification with no overweight calves at birth. A disadvantage of our procedure is that only $10 \%$ of embryos reached the EB stage on Day 6 and the $M$ to $X B$ development rates are lower without protein. However, we have tripled the EB-XB rates without protein by adding minute proportions of serum from Day 1 to Day 6 (Mullaart et al. 2015), before protein deprivation.

In conclusion, embryonic kinetics during blastocyst expansion greatly affect short- and long-term viability, with contrasting effects on embryo development rates and phenotypes of calves born when the embryos are vitrified, at least in the female subset. Therefore, it is possible to manipulate calf phenotypes affecting essential parameters such as birthweight by introducing simple changes in culture conditions combined with selection of embryos under specific development patterns before vitrification. 


\subsection{References}

Abe, H., Yamashita, S., Satoh, T., and Hoshi, H. (2002). Accumulation of cytoplasmic lipid droplets in bovine embryos and cryotolerance of embryos developed in different culture systems using serum-free or serum-containing media. Mol. Reprod. Dev. 61, 57-66. doi:10.1002/MRD.1131

Al Darwich, A., Perreau, C., Petit, M. H., Papillier, P., Dupont, J., Guillaume, D., Mermillod, P., and Guignot, F. (2010). Effect of PUFA on embryo cryoresistance, gene expression and AMPKalpha phosphorylation in IVFderived bovine embryos. Prostaglandins Other Lipid Mediat. 93, 30-36. doi:10.1016/J.PROSTAGLANDINS.2010.06.002

Al Darwich, A., Perreau, C., Tsikis, G., Coudert, E., Touze, J. L., Briant, E., Beckers, J. F., Mermillod, P., and Guignot, F. (2014). Effect of different culture systems on adipocyte differentiation-related protein (ADRP) in bovine embryos. Anim. Reprod. Sci. 145, 105-113. doi:10.1016/J.ANIREPROSCI.2014.01.010

Barceló-Fimbres, M., and Seidel, G. E., Jr (2011). Cross-validation of techniques for measuring lipid content of bovine oocytes and blastocysts. Theriogenology 75, 434-444. doi:10.1016/J.THERIOGENOLOGY.2010.09.007

Barcroft, L. C., Moseley, A. E., Lingrel, J. B., and Watson, A. J. (2004). Deletion of the $\mathrm{Na} / \mathrm{K}-\mathrm{ATPase}$ alpha1-subunit gene (Atp1a1) does not prevent cavitation of the preimplantation mouse embryo. Mech. Dev. 121, 417-426.

Bonilla, L., Block, J., Denicol, A. C., and Hansen, P. J. (2014). Consequences of transfer of an in vitro-produced embryo for the dam and resultant calf. J. Dairy Sci. 97, 229-239. doi:10.3168/JDS.2013-6943

Caamaño, J. N., Gómez, E., Trigal, B., Muñoz, M., Carrocera, S., Martín, D., and Díez, C. (2015). Survival of vitrified in vitro-produced bovine embryos after a one-step warming in-straw cryoprotectant dilution procedure. Theriogenology 83, 881-890. doi:10.1016/J.THERIOGENOLOGY.2014.11.021

Camargo, L. S., Freitas, C., de Sa, W. F., de Moraes Ferreira, A., Serapiao, R. V., and Viana, J. H. (2010).Gestation length, birth weight and offspring gender ratio of in vitro-produced Gyr (Bos indicus) cattle embryos. Anim. Reprod. Sci. 120, 10-15. doi:10.1016/J.ANIREPROSCI.2010.02.013

Cordova, A., Perreau, C., Uzbekova, S., Ponsart, C., Locatelli, Y., and Mermillod, P. (2014). Development rate and gene expression of IVP bovine embryos co-cultured with bovine oviduct epithelial cells at early or late stage of preimplantation development. Theriogenology 81, 1163-1173. doi:10.1016/J.THERIOGENOLOGY.2014.01.012 
Crosier, A. E., Farin, P. W., Dykstra, M. J., Alexander, J. E., and Farin, C. E. (2001). Ultrastructural morphometry of bovine blastocysts produced in vivo or in vitro. Biol. Reprod. 64, 1375-1385. doi:10.1095/BIOLREPROD64.5.1375

Denicol, A. C., Leaño, B. C., Dobbs, K. B., Mingoti, G. Z., and Hansen, P. J. (2015). Influence of sex on basal and Dickkopf-1 regulated gene expression in the bovine morula. PLoS One 10, e0133587. doi:10.1371/JOURNAL.PONE.0133587

Driver, A.M., Peñagaricano, F., Huang,W., Khawaja, R. A., Hackbart, K. S., Wiltbank, M. C., and Khatib, H. (2012). RNA-Seq analysis uncovers transcriptomic variations between morphologically similar in vivo- and in vitro-derived bovine blastocysts. BMC Genomics 13, 118. doi:10.1186/14712164-13-118

Elis, S., Coyral-Castel, S., Freret, S., Cognie', J., Desmarchais, A., Fatet, A., Rame, C., Briant, E., Maillard, V., and Dupont, J. (2013). Expression of dipokine and lipid metabolism genes in adipose tissue of dairy cows differing in a female fertility quantitative trait locus. J. Dairy Sci. 96, 75917602. doi:10.3168/JDS.2013-6615

Fleming, T. P., Kwong, W. Y., Porter, R., Ursell, E., Fesenko, I., Wilkins, A., Miller, D. J., Watkins, A. J., and Eckert, J. J. (2004). The embryo and its future. Biol. Reprod. 71, 1046-1054. doi:10.1095/BIOLREPROD.104.030957

Fleming, T. P., Watkins, A. J., Sun, C., Velazquez, M. A., Smyth, N. R., and Eckert, J. J. (2015). Do little embryos make big decisions? How maternal dietary protein restriction can permanently change an embryo. Reprod. Fertil. Dev. 27, 684-692. doi:10.1071/RD14455

Ghanem, N., Ha, A. N., Fakruzzaman, M., Bang, J. I., Lee, S. C., and Kong, I. K. (2014). Differential expression of selected candidate genes in bovine embryos produced in vitro and cultured with chemicals modulating lipid metabolism. Theriogenology

82, 238-250. doi:10.1016/J.THERIOGENOLOGY.2014.03.024

Gómez, E. (1997). Acetoacetate and beta-D-hydroxybutyrate as energy substrates during early bovine embryo development in vitro. Theriogenology 48, 63-74. doi:10.1016/S0093-691X(97)00191-X

Gómez,E.,Duque, P.,Díaz, E., Facal,N.,Antolín, I.,Hidalgo,C., and Díez,C. (2002). Effects of acetoacetate and D-beta-hydroxybutyrate on bovine in vitro embryo development in serum-free medium. Theriogenology 57, 15511562. doi:10.1016/S0093-691X(02)00660-X

Gómez, E., Rodríguez, A., Muñoz, M., Caamaño, J. N., Carrocera, S., Martín, D., Facal, N., and Díez, C. (2008). Development and quality of bovine morulae cultured in serum-free medium with specific retinoid receptor agonists. Reprod. Fertil. Dev. 20, 884-891. doi:10.1071/RD08103 
Gómez, E., Muñoz, M., Rodríguez, A., Caamaño, J.N., Facal, N., and Díez, C. (2009). Vitrification of bovine blastocysts produced in vitro inflicts selective damage to the inner cell mass. Reprod. Domest. Anim. 44, 194199. doi:10.1111/J.1439-0531.2007.01026.X

Gómez, E., Caamaño, J. N., Corrales, F. J., Díez, C., Correia-Álvarez, E., Martín, D., Trigal, B., Carrocera, S., Mora, M. I., Pello-Palma, J., Moreno, J. F., and Muñoz, M. (2013). Embryonic sex induces differential expression of proteins in bovine uterine fluid. J. Proteome Res. 12, 1199-1210. doi:10.1021/PR300845E

González-Serrano, A. F., Pirro, V., Ferreira, C. R., Oliveri, P., Eberlin, L. S., Heinzmann, J., Lucas-Hahn, A., Niemann, H., and Cooks, R. G. (2013). Desorption electrospray ionization mass spectrometry reveals lipid metabolism of individual oocytes and embryos. PLOS One 8, e74981. doi:10.1371/JOURNAL.PONE.0074981

Guerif, F., McKeegan, P., Leese, H. J., and Sturmey, R. G. (2013). A simple approach for COnsumption and RElease (CORE) analysis of metabolic activity in single mammalian embryos. PLOS One 8, e67834. doi:10.1371/JOURNAL.PONE.0067834

Gutiérrez-Adán, A., Behboodi, E., Andersen, G. B., Medrano, J. F., and Murray, J. D. (1996). Relationship between stage of development and sex of bovine IVM-IVF embryos cultured in vitro versus in the sheep oviduct. Theriogenology 46, 515-525. doi:10.1016/0093-691X(96) 00173-2

Gutiérrez-Adán, A., White, C. R., Van Soom, A., and Mann, M. R. (2015). Why we should not select the faster embryo: lessons from mice and cattle. Reprod. Fertil. Dev. doi: 10.1071/RD14216

Hidalgo, C. O., Gómez, E., Prieto, L., Duque, P., Goyache, F., Fernández, L., Fernández, I., Facal, N., and Díez, C. (2004). Pregnancy rates and metabolic profiles in cattle treated with propylene glycol prior to embryo transfer. Theriogenology 62, 664-676. doi:10.1016/J.THERIOGENOLOGY.2003.11.006

Hughes, J., Kwong, W. Y., Li, D., Salter, A. M., Lea, R. G., and Sinclair, K. D. (2011). Effects of omega-3 and -6 polyunsaturated fatty acids on ovine follicular cell steroidogenesis, embryo development and molecular markers of fatty acid metabolism. Reproduction 141, 105-118. doi:10.1530/REP-10-0337

Kenyon, A. G., Mendonca, L. G. D., Lopes, G., Lima, J. R., Santos, J. E. P., and Chebel, R. C. (2013). Minimal progesterone concentration required for embryo survival after embryo transfer in lactating Holstein cows. Anim. Reprod. Sci. 136, 223-230. doi:10.1016/J.ANIREPROSCI.2012. 10.014

Kimura, K., Spate, L. D., Green, M. P., and Roberts, R. M. (2005). Effects of Dglucose concentration, D-fructose, and inhibitors of enzymes of the 
pentose phosphate pathway on the development and sex ratio of bovine blastocysts. Mol. Reprod. Dev. 72, 201-207. doi:10.1002/MRD.20342

Krisher, R. L., Heuberger, A. L., Paczkowski, M., Stevens, J., Pospisil, C., Prather, R. S., Sturmey, R. G., Herrick, J. R., and Schoolcraft, W. B. (2015). Applying metabolomic analyses to the practice of embryology: physiology, development and assisted reproductive technology. Reprod. Fertil. Dev. doi:10.1071/RD14359

Larson, M. A., Kimura, K., Kubisch, H. M., and Roberts, R. M. (2001). Sexual dimorphism among bovine embryos in their ability to make the transition to expanded blastocyst and in the expression of the signalling molecule IFN-t. Proc. Natl. Acad. Sci. USA 98, 9677-9682. doi:10.1073/PNAS.171305398

Leese, H. J.,Baumann,C.G., Brison, D. R.,McEvoy,T. G., and Sturmey,R. G. (2008). Metabolism of the viable mammalian embryo: quietness revisited. Mol. Hum. Reprod. 14, 667-672. doi:10.1093/MOLEHR/GAN065

Liang, Q. X., Zhang, Q. H., Qi, S. T., Wang, Z. W., Hu, M. W., Ma, X. S., Zhu, M. S., Schatten, H., Wang, Z. B., and Sun, Q. Y. (2015). Deletion of Mylk1 in oocytes causes delayed morula-to-blastocyst transition and reduced fertility without affecting folliculogenesis and oocyte maturation in mice. Biol. Reprod. 92, 97. doi:10.1095/BIOLREPROD.114.122127

Lonergan, P.,Khatir,H., Piumi, F., Rieger,D., Humblot, P., and Boland, M. P. (1999). Effect of time interval from insemination to first cleavage on the developmental characteristics, sex ratio and pregnancy rate after transfer of bovine embryos. J. Reprod. Fertil. 117, 159-167. doi:10.1530/JRF.0.1170159

Lonergan, P., Rizos, D., Guitierrez-Adan, A., Fair, T., and Boland, M. P. (2003). Effect of culture environment on embryo quality and gene expression experience from animal studies. Reprod. Biomed. Online 7, 657-663. doi:10.1016/S1472-6483(10)62088-3

Mann, G. E., and Lamming, G. E. (2001). Relationship between maternal endocrine environment, early embryo development and inhibition of the luteolytic mechanism in cows. Reproduction 121, 175-180. doi:10.1530/REP.0.1210175

Merton, J. S., Vermeulen, Z. L., Otter, T., Mullaart, E., and de Ruigh, L. (2003). A combined morphological evaluation of in vitro-produced bovine embryos at Days 6 and 7 of culture, enhances discrimination in embryo quality with regard to pregnancy rate. Theriogenology 59, 346.

Mullaart, E., Dotinga, F., Ponsart, C., Knijn, H., and Schouten, J. (2015). Addition of very low amounts of serum (estrus cow serum) improves in vitro embryo production in dairy cattle. Reprod. Fertil. Dev. 27, 205-206. doi:10.1071/RDV27N1AB232 
Muñoz, M., Uyar, A., Correia, E., Díez, C., Fernández-González, A., Caamaño, J. N., Martínez-Bello, D., Trigal, B., Humblot, P., Ponsart, C., Guyader- Joly, C., Carrocera, S., Martín, D.,Marquant Le Guienne, B., Seli, E., and Gómez, E. (2014a). Prediction of pregnancy viability in bovine in vitroproduced embryos and recipient plasma with Fourier transform infrared spectroscopy. J. Dairy Sci. 97, 5497-5507. doi:10.3168/JDS.2014-8067

Muñoz, M., Uyar, A., Correia, E., Díez, C., Fernández-González, A., Caamaño, J. N., Trigal, B., Carrocera, S., Seli, E., and Gómez, E. (2014b). Non-invasive assessment of embryonic sex in cattle by metabolic fingerprinting of in vitro culture medium. Metabolomics 10, 443-451. doi:10.1007/S11306-013-0587-9

Murillo-Ríos, A., Maillo, V., Muñoz, M., Gutiérrez-Adán, A., Carrocera, S., Martín-González, D., Fernández-Buznego, A. E., and Gómez, E. (2016). Shortand long-term outcomes of the absence of protein during bovine blastocyst formation in vitro. Reprod. Fertil. Dev. doi:10.1071/RD15485

Reis, A., Rooke, J. A., McCallum, G. J., Staines, M. E., Ewen, M., Lomax, M. A., and McEvoy, T. G. (2003). Consequences of exposure to serum, with or without vitamin $E$ supplementation, in terms of the fatty acid content and viability of bovine blastocysts produced in vitro. Reprod. Fertil. Dev. 15, 275-284. doi:10.1071/RD03004

Rizos, D., Fair, T., Papadopoulos, S., Boland, M. P., and Lonergan, P. (2002). Developmental, qualitative, and ultrastructural differences between ovine and bovine embryos produced in vivo or in vitro. Mol. Reprod. Dev. 62, 320-327. doi:10.1002/MRD.10138

Romek, M., Gajda, B., Krzysztofowicz, E., Kepczynski, M., and Smorag, Z. (2011). Lipid content in pig blastocysts cultured in the presence or absence of protein and vitamin $\mathbf{E}$ or phenazine ethosulfate. Folia Biol. (Krakow) 59, 45-52. doi:10.3409/FB59_1-2.45-52

Sanches, B. V., Marinho, L. S., Filho, B. D., Pontes, J. H., Basso, A. C., Meirinhos, M. L., Silva-Santos, K. C., Ferreira, C. R., and Seneda, M. M. (2013). Cryosurvival and pregnancy rates after exposure of IVF-derived Bos indicus embryos to forskolin before vitrification. Theriogenology 80, 372377. doi:10.1016/J.THERIOGENOLOGY.2013.04.026

Spiegler, S., Kaske, M., Ko"hler, U., Meyer, H. H., Schwarz, F. J., and Wiedemann, S. (2014). Effect of feeding level of pregnant dairy heifers sired by one bull on maternal metabolism, placental parameters and birth weight of their female calves. Anim. Reprod. Sci. 146, 148-156. doi:10.1016/J.ANIREPROSCI.2014.03.007

Sturmey, R. G., Bermejo-Alvarez, P., Gutierrez-Adan, A., Rizos, D., Leese, H. J., and Lonergan, P. (2010). Amino acid metabolism of bovine blastocysts: a biomarker of sex and viability. Mol. Reprod. Dev. 77, 285-296. doi:10.1002/MRD.21173 
Sudano, M. J., Paschoal, D. M., Rascado, T. S., Magalhães, L. C., Crocomo, L. F., de Lima-Neto, J. F., and Landim-Alvarenga, F. C. (2011). Lipid content and apoptosis of in vitro-produced bovine embryos as determinants of susceptibility to vitrification. Theriogenology 75, 1211-1220. doi:10.1016/J.THERIOGENOLOGY.2010.11.033

Sudano, M. J., Caixeta, E. S., Paschoal, D. M., Martins, A., Jr, Machado, R., Buratini, J., and Landim-Alvarenga, F. D. (2014). Cryotolerance and global gene-expression patterns of Bos taurus indicus and Bos taurus taurus in vitro- and in vivo-produced blastocysts. Reprod. Fertil. Dev. 26, 1129-1141. doi:10.1071/RD13099

Sudano, M. J., Rascado, T. D. S., Tata, A., Belaz, K. R. A., Santos, V. G., Valente, R. S., Mesquita, F. S., Ferreira, C. S., Araujo, J. P., Eberlin, M. N., and Landim-Alvarenga, F. D. C. (2016). Lipidome signatures in early bovine embryo development. Reprod. Fertil. Dev. 28, 210. doi:10.1071/RDV28N2AB160

Sugimura, S., Akai, T., Somfai, T., Hirayama, M., Aikawa, Y., Ohtake, M., Hattori, H., Kobayashi, S., Hashiyada, Y., Konishi, K., and Imai, K. (2010). Time-lapse cinematography-compatible polystyrene-based microwell culture system: a novel tool for tracking the development of individual bovine embryos. Biol. Reprod. 83, 970-978. doi:10.1095/BIOLREPROD.110.085522

Sugimura, S., Akai, T., Hashiyada, Y., Somfai, T., Inaba, Y., Hirayama, M., Yamanouchi, T., Matsuda, H., Kobayashi, S., Aikawa, Y., Ohtake, M., Kobayashi, E., Konishi, K., and Imai, K. (2012). Promising system for selecting healthy in vitro-fertilized embryos in cattle. PLoS One 7, e36627. doi:10.1371/JOURNAL.PONE.0036627

Sullivan, T. M., Micke, G. C., Magalhaes, R. S., Phillips, N. J., and Perry, V. E. (2009). Dietary protein during gestation affects placental development in heifers. Theriogenology 72, 427-438. doi:10.1016/J.THERIOGENOLOGY.2009.03.018

Takahashi, T., Inaba, Y., Somfai, T., Kaneda, M., Geshi, M., Nagai, T., and Manabe, N. (2013). Supplementation of culture medium with L-carnitine improves development and cryotolerance of bovine embryos produced in vitro. Reprod. Fertil. Dev. 25, 589-599. doi:10.1071/RD11262

Thiam, A. R., Farese, R. V., Jr, and Walther, T. C. (2013). The biophysics and cell biology of lipid droplets. Nat. Rev. Mol. Cell Biol. 14, 775-786. doi:10.1038/NRM3699

Thompson, J. G., Sherman, A. N., Allen, N. W., McGowan, L. T., and Tervit, H. R. (1998). Total protein content and protein synthesis within preelongation stage bovine embryos. Mol. Reprod. Dev. 50, 139-145. doi:10.1002/(SICI)1098-2795(199806)50:2,139::AID-MRD3.3.0.CO;2-L 
Trigal, B., Gómez, E., Caamaño, J. N., Muñoz, M., Moreno, J., Carrocera, S., Martín, D., and Díez, C. (2012a). In vitro and in vivo quality of bovine embryos in vitro produced with sex-sorted sperm. Theriogenology 78, 1465-1475. doi:10.1016/J.THERIOGENOLOGY.2012.06.018

Trigal, B., Gómez, E., Díez, C., Caamaño, J. N., Muñoz, M., Moreno, J. F., Carrocera, S., Martín, D., Goyache, F., and Álvarez, I. (2012b). Comparative study of PCR-sexing procedures using bovine embryos fertilized with sexsorted spermatozoa. Span. J. Agric. Res. 10, 353-359. doi:10.5424/SJAR/2012102-447-11

Trigal, B., Díez, C., Muñoz, M., Caamaño, J. N., Goyache, F., Correia-Álvarez, E., Corrales, F. J., Mora, M. I., Carrocera, S., Martin, D., and Gómez, E. (2014). Elements of functional genital asymmetry in the cow. Reprod. Fertil. Dev. 26, 493-501. doi:10.1071/RD13056

Vandaele, L., Goossens, K., Peelman, L., and Van Soom, A. (2008). mRNA expression of Bcl-2, Bax, caspase-3 and -7 cannot be used as a marker for apoptosis in bovine blastocysts. Anim. Reprod. Sci. 106, 168-173. doi:10.1016/J.ANIREPROSCI.2007.12.016

Watkins, A. J., Papenbrock, T., and Fleming, T. P. (2008). The preimplantation embryo: handle with care. Semin. Reprod. Med. 26, 175185. doi:10.1055/S-2008-1042956 


\title{
5 | CAPÍtulo III
}

\section{Low serum concentration in bovine embryo culture enhances early blastocyst rates on Day- 6 with quality traits in the expanded blastocyst stage similar to BSA-cultured embryos}

\author{
A. Murillo ${ }^{a, *}$, M. Muñoz ${ }^{a}$, D. Martín-González ${ }^{a}$, S. Carrocera ${ }^{a}$, A. Martínez-Nistal, E. \\ Gómez ${ }^{a}$ \\ ${ }^{a}$ Centro de Biotecnología Animal, SERIDA, Camino de Rioseco 1225, 33394 Gijón, \\ Spain \\ b Unidad de Microscopía Fotónica y Proceso de Imágenes, Servicios Científico \\ Técnicos, Universidad de Oviedo, Asturias, Spain
}

Reproductive Biology 2017. 17(2), 162-171

Project support was provided by the Spanish Ministry of Economy and CompetitivenessMINECO-project AGL2016- 78597-R, Principado de Asturias, Plan de Ciencia, Tecnología e Innovación 2013-2017 (GRUPIN 14-114) and FEDER. AM was supported by Secretaría Nacional de Educación Superior, Ciencia, Tecnología e Innovación - Ecuador - II Fase 2013. The authors are members of the COST Action FA1201 Epiconcept: Epigenetics and Periconception environment. 


\section{Abstract}

In bovine, single in vitro embryo culture in protein-free medium from Day-6 to Day-7 leads to expanded blastocyst $(\mathrm{XB})$ with improved pregnancy and birth rates after cryopreservation. Under these conditions, early blastocysts (EB) progress to the $\mathrm{XB}$ stage at higher rates than morulae (M). However, embryo production with BSA in culture prior to Day-6 leads to low EB rates. We investigated whether a very low FCS concentration (0.1\%) in culture from Day-1 to Day- 6 would improve EB rates and, subsequently, increase XB rates on Day7 after single culture in protein-free medium. The quality of embryos produced was evaluated in terms of survival to cryopreservation, apoptosis percentage, lipid accumulation and transfer to recipients. On Day-6, EB rates from embryos cultured with FCS were higher than with BSA $(P=0.022)$. On Day-7, XB rates were higher in embryos from Day-6 EB than from Day-6 $M$, both with and without FCS $(P<0.005)$. After vitrification/warming of Day-7 XB, 100\% embryos survived at $24 \mathrm{~h}$ in all treatments, and total cell number and apoptosis percentage were not affected by the presence of FCS or embryonic stage on Day-6. Cryopreserved and fresh embryos produced with FCS until Day-6, and then deprived of protein and cultured individually, led to pregnancies after ET. In conclusion, minute FCS concentration improves EB rates on Day-6 leading, after one-day single culture without protein, to more $\mathrm{XBs}$. The quality of $\mathrm{XB}$ produced with FCS compares well with XB produced with BSA in terms of apoptosis, lipid accumulation and pregnancy. 


\subsection{Introduction}

Defined in vitro culture media (CM) have been created to help avoiding sanitary concerns and to normalize culture conditions. In addition, defined CM improves repeatability, inter-laboratory comparisons, and facilitates reliable analysis of media [1-3]. In bovine, compared with group culture, long-term single culture in simple medium reduces embryo development rates, embryo quality, survival to cryopreservation and pregnancy viability [4]. Nevertheless, we observed that an individual culture limited to after Day-6 improved embryo development competence, allowing embryo traceability and non-invasive analysis of $\mathrm{CM}$, such as prediction of pregnancy rates $[5,6]$, and embryonic sex $[7,8]$. We have recently shown that single embryo culture for $24 \mathrm{~h}$ in a protein-free medium, resulted in Day-7 embryos with improved birth rates after vitrification and transfer to recipients [9]. Furthermore, protein removal did not affect birth weight, gestation length or morphometry of calves in comparison with embryos cultured with protein [10]. In previous studies, we observed that one-day single culture without protein from Day-6 onwards increased rates of Day-7 expanded blastocyst that derived from Day- 6 early blastocysts (EB-XB) over those from Day-6 morulae (M-XB) [9,10]. Furthermore, calves born after transfer of vitrified/warmed embryos from Day-7 EB-XB have lower birthweight than calves derived from Day-7 M-XB [10]. In cattle, high birthweight increases the risks of dystocia, fetal death, neonatal mortality, and damage to the dam $[11,12]$. However, in our culture conditions with BSA prior to Day- 6 only $10 \%$ of embryos reach the early blastocyst stage on Day-6. Thus, improving early blastocyst rates on Day-6 is necessary in order to obtain more expanded blastocysts on Day-7. In vitro produced bovine embryos at the expanded blastocyst stage on 
Day-7 lead to the highest pregnancy rates both as fresh and cryopreserved [5,13-15]. Serum supplementation in embryo culture media at concentrations of $1 \%$ to $20 \%(\mathrm{v} / \mathrm{v})$ has usually been used to enhance kinetics of embryo development and blastocyst rates [16-20]. However, with high serum concentrations in CM, abnormalities and deficiencies in embryo quality also have been described [19-25]. As a strategy to minimize detrimental effects of serum supplementation, serum concentrations in the CM were reduced as much as possible. Thus, Mullaart et al. [26] showed that a very low serum concentration $(0.1 \%, v / v)$ throughout the entire culture improved blastocyst production. However, no data on embryo quality, survival of cryopreservation or pregnancy viability has been reported. Single culture without protein is potentially compatible with other previous culture steps $[9,10]$. We hypothesized that very low concentration of serum in culture, from Day-1 up to Day-6, could improve early blastocyst rates which, after single culture without protein, would subsequently increase expanded blastocyst rates on Day-7. However, adverse effects of serum on the embryonic quality [20,27] and viability [28] need to be evaluated, prior to introducing a large-scale, embryo transfer study. The objectives of this study were (1) to improve the expanded blastocysts production on Day-7 with the addition of $0.1 \%$ fetal calf serum (FCS) prior to a $24 \mathrm{~h}$ single culture without protein, and (2) to evaluate the quality of produced embryos in terms of survival to cryopreservation, apoptosis rates and lipid accumulation. In addition, a preliminary trial of embryo transfer (ET) was performed to evaluate the viability of fresh and cryopreserved embryos. 


\subsection{Material and Methods}

All experimental procedures were approved by the Animal Research Ethics Committee of SERIDA (Agreement 02/02/2012), in accordance with the European Community Directive 86/609/EC. All reagents were purchased from SIGMA (Madrid, Spain) unless otherwise stated.

\subsubsection{Oocyte collection and in vitro maturation (IVM)}

Ovaries were collected from cows slaughtered in a commercial abattoir (Matadero de Guarnizo, Cantabria, Spain). Ovaries were transported to the laboratory in $\mathrm{NaCl}$ solution (9 $\mathrm{mg} / \mathrm{mL}$ ) with penicillin $100 \mathrm{IU} / \mathrm{mL}$ and streptomycin sulfate $100 \mathrm{mg} / \mathrm{mL}$, and maintained at $25^{\circ} \mathrm{C}$ to $30^{\circ} \mathrm{C}$. Antral follicles (3 to $8 \mathrm{~mm}$ in diameter) were aspirated through an $18 \mathrm{~g}$ needle connected to a syringe. Aspirated fluid was expelled into dishes containing holding medium (HM) TCM199 (Invitrogen, Barcelona, Spain), 25 mM HEPES and $0.4 \mathrm{mg} \mathrm{mL}^{-1}$ BSA. A search for oocytes was carried out using a stereomicroscope, and only good- quality oocytes with more than three layers of compact cumulus cells with homogenous cytoplasm were selected. For in vitro maturation (IVM), the cumulus-oocyte complexes (COCs) were rinsed three times in HM. Selected COCs were washed three times in maturation medium (MM) consisting of $\mathrm{TCM} 199 \mathrm{NaHCO}_{3}\left(2.2 \mathrm{mg} \mathrm{mL}^{-1}\right)$ supplemented with $10 \%$ (v/v) FCS (SIGMA F4135), $1.5 \mathrm{mg} \mathrm{mL}^{-1}$ of porcine FSH-LH (Stimufol; ULg FMV, Liège, Belgium) and $1 \mathrm{mg} \mathrm{mL}^{-1} 17 \beta$-estradiol. COCs were transferred $(\mathrm{n}=30$ 50) along with $500 \mathrm{~mL}$ of IVM medium into each well of a four-well dish for 22$24 \mathrm{~h}$ at $38.7^{\circ} \mathrm{C}$ in $5 \% \mathrm{CO}_{2}$ atmosphere with saturated humidity. 


\subsubsection{Sperm preparation and in vitro fertilization (IVF)}

Commercial frozen sperm from an Asturiana de los Valles bull with proven fertility was thawed and used for IVF (Day 0). Motile sperm was obtained by a swim-up procedure [23]. Briefly, semen from one frozen straw corresponding to one bull was thawed in a water bath (30 s) and added to a polystyrene tube containing $1 \mathrm{~mL}$ of pre-equilibrated Sperm-TALP (Tyrode's albumin lactate pyruvate). After $1 \mathrm{~h}$ incubation, the supernatant upper layer containing motile sperm was recovered. Sperm was centrifuged for $7 \mathrm{~min}$ at $200 \mathrm{xg}$ and the supernatant was aspirated to leave a pellet. The concentration of spermatozoa was determined with a hemocytometer. COCs were washed twice in HM and placed in four-well culture dishes containing pre-equilibrated fertilization medium (Fert- TALP) with heparin $\left(10 \mathrm{mg} \mathrm{mL}^{-1}\right.$; Calbiochem, La Jolla, CA, USA). Spermatozoa were added at a concentration of $2 \times 10^{6}$ cells $\mathrm{mL}^{-1}$ in 500 $\mathrm{mL}$ of medium per well, containing a maximum of 100 COCs. IVF was accomplished by incubating oocytes and sperm cells together for 18 to $20 \mathrm{~h}$ at $38.7 \stackrel{\circ}{\circ} \mathrm{C}$ in $5 \% \mathrm{CO}_{2}$ atmosphere with saturated humidity.

\subsubsection{In vitro culture}

Cumulus cells were detached using a vortex and fertilized oocytes were cultured in modified synthetic oviduct fluid (mSOF) containing amino acids (BME amino acids solution, $45 \mathrm{~mL} \mathrm{~mL}^{-1}$ and MEM non- essential amino acids solution, $\left.3.3 \mathrm{~mL} \mathrm{~mL}^{-1}\right)$, citrate $\left(0.1 \mathrm{mg} \mathrm{mL}^{-1}\right)$, myo-inositol $\left(0.5 \mathrm{mg} \mathrm{mL}^{-1}\right)$, and BSA (6 mg mL $\left.{ }^{-1}\right)$ with $0.1 \%(v / v)$ FCS (SIGMA F4135; $\left.\mathrm{n}=908\right)$ or without FCS $(\mathrm{n}=1133)$. In vitro culture was carried out at $38.7 \stackrel{\circ}{\circ} \mathrm{C}, 5 \% \mathrm{CO}_{2}, 5 \% \mathrm{O}_{2}, 90 \% \mathrm{~N}_{2}$, and saturated humidity. On Day-6 (143 h PI), excellent and good quality (grade 
1 and grade 2 [29]) morulae and early blastocysts were selected and cultured individually in $12 \mathrm{~mL}$ mSOF with $0.5 \mathrm{mg} \mathrm{mL}^{-1}$ polyvinyl- alcohol PVA (instead of BSA) under mineral oil. Blastocyst development was monitored on Day-7 (168 h PI).

\subsubsection{Embryo vitrification, warming and in vitro survival}

Vitrification procedures have been described in detail [30]. Briefly, Day-7 excellent and good quality (grade 1 and grade 2 [29]) expanded blastocysts were vitrified in two-steps with fiber plugs (CryoLogic Vitrification Method; CVM). All procedures were performed in a warm room $\left(25^{\circ} \mathrm{C}\right)$ on a heated surface $\left(41^{\circ} \mathrm{C}\right)$. Embryos were first handled in a basic vitrification medium (VM), consisting of TCM 199-HEPES $+20 \%$ (v/v) FCS. Groups of one to five blastocysts were exposed to VM with $7.5 \%$ ethylene-glycol (EG), 7.5\% DMSO (vitrification solution-1) for $3 \mathrm{~min}$, and then moved into a microdrop containing VM with $16.5 \% \mathrm{EG}, 16.5 \%$ DMSO and $0.5 \mathrm{M}$ sucrose (vitrification solution-2; VS2). The time spent by the embryos in VS2 (including loading) was 20-25 s. Samples were vitrified by touching the surface of a supercooled block placed in $\mathrm{LN}_{2}$ with a hook. Vitrified embryos were stored in closed straws for up 6 months in liquid nitrogen $\left(-196^{\circ} \mathrm{C}\right)$ until warming. Embryos were warmed in one step [31] by directly immersing the fibreplug end in $800 \mathrm{~mL}$ of $0.25 \mathrm{M}$ sucrose in VM, where the embryo was kept for 5 min and subsequently transferred and washed twice in VM. In vitro survival rates were analyzed after warming and subsequent in vitro culture of Day-7 vitrified embryos in droplets of $25 \mathrm{~mL}$ of $\mathrm{mSOF}$ containing $6 \mathrm{mg} \mathrm{mL}^{-1} \mathrm{BSA}$ and 10\% FCS (v/v; SIGMA F4135). Embryo survival was evaluated in terms of re-expansion and hatching rates at 24 and $48 \mathrm{~h}$. 


\subsubsection{Apoptosis in blastocysts: TUNEL assay}

Excellent and good quality hatched blastocysts (grade 1 and grade 2 [29]) surviving vitrification/warming were fixed in $4 \%$ paraformaldehyde with $0.1 \mathrm{mg}$ $\mathrm{mL}^{-1}$ PVA and then washed and stored in phosphate buffered saline (SIGMA P4417) with $0.1 \mathrm{mg} \mathrm{mL}^{-1}$ PVA (PBS-PVA; $\mathrm{pH}=7.4,4 \stackrel{\circ}{\circ} \mathrm{C}$ ) until use. Embryos were permeabilized for $40 \mathrm{~min}$ at room temperature with sodium citrate $(0.1 \mathrm{M}$; $\mathrm{pH}=6.0$; SIGMA C8532) containing PVA $\left(0.2 \mathrm{mg} \mathrm{mL}^{-1}\right)$ and Triton $(0.1 \% \mathrm{v} / \mathrm{v})$, and subsequently washed twice in PBS-PVA with Triton $(0.5 \% \mathrm{v} / \mathrm{v})$. Next, embryos were incubated on drops of $50 \mathrm{~mL}$ of Image iT-Tx Signal Enhancer (Invitrogen, I36933) for $30 \mathrm{~min}$ at room temperature, washed twice with PBSPVA and incubated with labeling reagent according to the manufacturer's instructions (In situ Cell Death Detection Kit with Fluorescein, Roche1, Mannheim, BW, Germany). Positive controls for TUNEL were carried out by treating embryos with $10 \mathrm{IU} \mathrm{mL} \mathrm{m}^{-1}$ of DNase I (Takara, 2215A). All samples were incubated in micro-drops of the TUNEL Kit containing $10 \%$ of the enzymatic solution (deoxinucleotidil terminal transferase enzyme) with $90 \%$ of the labeling solution (20- deoxyuridine 50-triphosphate-dUTP + fluorescein isothiocyanateconjugated-FITC) for $1 \mathrm{~h}$ in a humid chamber at $37^{\circ} \mathrm{C}$ in the dark. In a parallel assay, embryos were incubated in micro-drops containing only labeling solution as negative control. For nuclei counter- staining, embryos were incubated with $400 \mathrm{~mL}$ 4, 6-diamidino-2- phenylindole (DAPI) dye (300 nM in PBS) for 2 min at room temperature, washed in PBS-PVA solution, and finally mounted on a glass slide with Vectashield-H1000 (Vector Labs, USA) under a coverslip. Embryos were analyzed with a confocal microscope (ultra-spectral Leica TCS-SP8AOBS; Leica Microsystems, Mannheim, Germany). An excitation wavelength of 
$488 \mathrm{~nm}$ was selected for detection of fluorescein-12-dUTP and a $405 \mathrm{~nm}$ wavelength to excite DAPI. Photomicrograph of serial optical sections were recorded every 1.5-2 $\mathrm{mm}$ vertical step along the Z-axis of each embryo. Total embryonic cells and DNA-fragmented nuclei were analyzed using software ImageJ (Confocal Uniovi ImageJ; version 1.51). Nuclei with green fluorescence (FITC) were considered TUNEL positive (fragmented DNA). Total healthy and apoptotic cells were assessed by DAPI staining of based on the presence of blue fluorescence. The results were expressed as total cells number and TUNEL-positive apoptosis percentage.

\subsubsection{Lipids and cell nuclei staining and quantification}

The following excellent and good quality embryos were selected to the analysis: (I) Day-6 morulae produced in the absence or the presence of $0.1 \% \mathrm{FCS}$, and (II) Day-7 M-XB and EB-XB produced with or without $0.1 \%$ FCS up to Day-6, and subsequently individually cultured without protein for $24 \mathrm{~h}$. Lipid dye and quantification procedures have been described in detail [10]. Briefly, embryos were fixed in $4 \%$ paraformaldehyde with $0.1 \mathrm{mg} \mathrm{mL}^{-1}$ PVA for $20 \mathrm{~min}$ at room temperature and kept in PBS-PVA overnight. Nile red (SIGMA N3013) stock solution was prepared by dissolving $1 \mathrm{mg} \mathrm{mL}^{-1}$ lipid-specific Nile red dye in DMSO, which was stored in the dark. Embryos were washed for 1 min with 400 $\mathrm{mL}$ of $1 \mathrm{mg} \mathrm{mL}^{-1}$ Nile red stock solution in PBS-PVA [39], and then stained for 1 $\mathrm{h}$ in darkness. Embryos were washed again in PBS-PVA, and transferred into a well dish with $400 \mathrm{~mL}$ DAPI dye (300 nM in PBS) for 2 min and washed three times in PBS-PVA. Blastocysts stained with only DAPI were used as negative control. Finally, embryos were mounted on a slide with Vectashield $\mathrm{H}-1000$ 
(Vector Labs, USA) under a cover slip. Samples were stored in the dark at $4{ }^{\circ} \mathrm{C}$ overnight and examined under a confocal microscope (ultra-spectral Leica TCSSP8-X; Leica Microsystems, Mannheim, Germany). The lipophilic fluorescent Nile red dye was excited at $488 \mathrm{~nm}$, which allows the observation of neutral lipids, including esterified cholesterol and triglycerides, and DAPI was excited at $405 \mathrm{~nm}$. Next, digital photomicrographs of complete embryos, each $1.5 \mathrm{~mm}$ on Z plane, were captured using an immersion objective (HC-PL-APO-CS2 40x/1.30 oil) and acquisition software (Leica Application Suite X version 1.8.1). IMARIS 7.1.1 software (Bitplane Oxford Instruments, Zurich, Switzerland) was used to generate three-dimensional (3D) reconstructions from confocal datasets to assess lipid droplet contents. Only morphologically healthy nuclei stained with DAPI were counted. Lipid droplets (LD) were counted and measured in volume mode but arranged by diameter as small $(<2 \mu \mathrm{m})$, medium (from $2 \mu \mathrm{m}$ to $6 \mu \mathrm{m})$, and large $(>6 \mu \mathrm{m})$, in order to facilitate comparisons with measurements in diameter from previous work [32].

\subsubsection{Estrus synchronization of recipients, embryo transfer and pregnancy diagnosis}

Detailed procedures for estrus synchronization of recipients and embryo transfer have been described [33]. Briefly, cyclic crossbreed heifers were synchronized in estrus by using an intravaginal progestagen device (PRID Alpha, Ceva Salud Animal, Barcelona, Spain) for 10 days, combined with a prostaglandin analog (Dynolytic, Pfizer, Madrid, Spain) injected $48 \mathrm{~h}$ before progestagen removal. Embryos cultured with or without $0.1 \%$ FCS up to Day-6, and thereafter individually cultured until Day-7, were selected for a preliminary 
ET trial. Fresh or vitrified/warmed Day-7 produced blastocysts and expanded blastocyst were nonsurgically transferred to recipients in the cranial third of the uterine horn ipsilateral to corpus luteum under epidural anesthesia. The selection of recipients for fixed time ET required Day-7 progesterone (P4) serum levels $>2.5 \mathrm{ng} / \mathrm{mL}$ and Day-0 P4 serum levels $<2.0 \mathrm{ng} / \mathrm{mL}$. Pregnancy was diagnosed by transrectal ultrasound scanning on Day-40 and Day-60.

\subsubsection{Experimental design (Fig.5.1)}

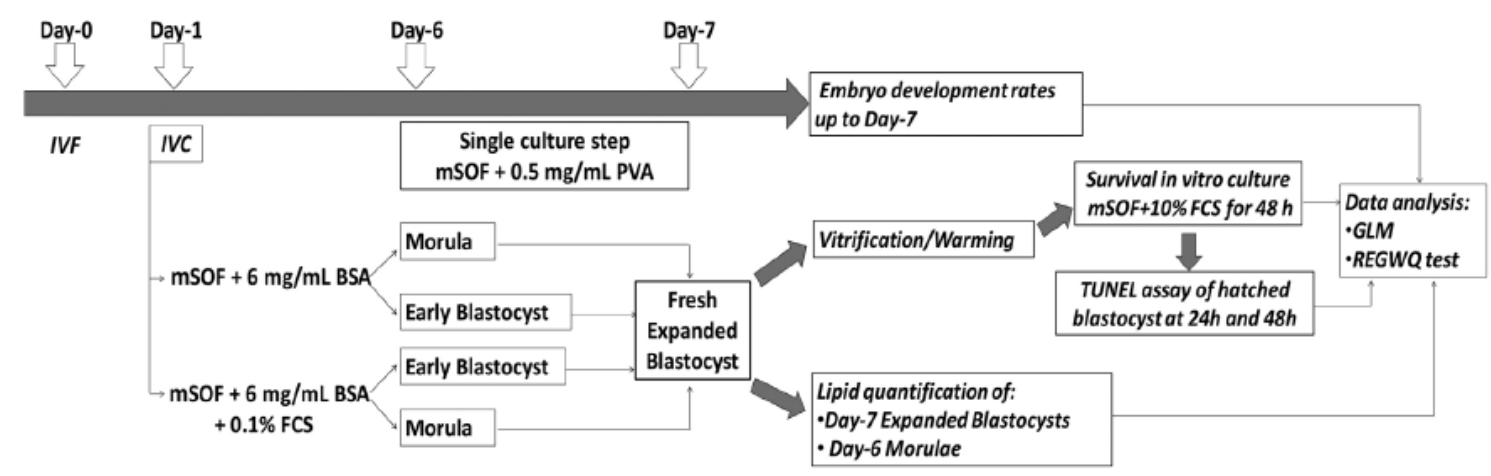

Fig. 5.1. Experimental design

\subsubsection{Experiment 1: FCS (0.1\%) supplementation and embryo}

\section{development}

The objective of experiment 1 was to determine the effects of $0.1 \%$ FCS in CM from Day-1 to Day-6 prior to a $24 \mathrm{~h}$ single culture without protein. After fertilization, zygotes were randomly cultured in two different conditions from Day-1 to Day-6: (i): $\mathrm{mSOF}+6 \mathrm{mg} \mathrm{mL}^{-1} \mathrm{BSA}$, and (ii): $\mathrm{mSOF}+6 \mathrm{mg} \mathrm{mL}^{-1} \mathrm{BSA}$ with $0.1 \%$ FCS. On Day 6 , morulae and early blastocysts from each of these two groups were selected and cultured individually without protein in 7 replicates. Blastocyst development was monitored on Day-7 (168 h PI) 


\subsubsection{Experiment 2: FCS (0.1\%) supplementation and in vitro survival to cryopreservation}

Experiment 2 aimed at assessing whether embryo survival to vitrification/warming after a $24 \mathrm{~h}$ single culture without protein was affected by previous culture from Day-1 to Day-6 with FCS. Excellent and good quality fresh expanded blastocysts were selected and vitrified in 7 replicates and warmed in 4 replicates. Re-expansion and hatching rates were monitored at $24 \mathrm{~h}$ and $48 \mathrm{~h}$ time points.

\subsubsection{Experiment 3: FCS $(0.1 \%)$ supplementation and apoptosis rates of} vitrified/warmed Day-7 expanded blastocysts

The aim was to evaluate the percentage of apoptosis and total cell counts on hatched blastocysts produced in the experiment 2 after vitrification/warming $(\mathrm{n}=$ 48 embryos vitrified from 7 culture replicates and warmed in 4 replicates). Embryos were fixed at $24 \mathrm{~h}$ and $48 \mathrm{~h}$ and stained with -TUNEL and DAPIassay in 4 replicates.

\subsubsection{Experiment 4: FCS $(0.1 \%)$ supplementation and lipid contents of Day-6 morulae and Day-7 expanded blastocysts}

The lipid accumulation per embryonic cell was analyzed in fresh Day-7 expanded blastocysts ( $n=62$ embryos), as well as in fresh Day- 6 morulae $(n=$ 36 embryos) produced with or without $0.1 \%$ FCS. Morula is the earliest embryonic stage selected for single culture without protein. A total of 5 replicates were evaluated. 


\subsubsection{Statistical analysis}

Data requiring normalization were arcsine transformed and analyzed using the Proc GLM module of SAS/STAT (version 9.2; SAS Institute Inc., Cary, NC). In experiment regarding embryo development up to Day-6, the fixed effects included were the presence of FCS in culture media from Day- 1 to Day- 6 and replicate. In experiments regarding development after protein deprivation, in vitro survival to vitrification/warming, apoptosis rates and lipid droplets evaluation, the fixed effects included were the presence of FCS in culture media from Day-1 to Day-6, embryonic stage on Day-6, interactions between FCS in culture media from Day-1 to Day-6 and embryonic stage on Day-6 and replicate. Least squares means and their errors (LSM \pm S.E.M.) were estimated for each level of fixed effects with a significant F-value. The Ryan-EinotGabriel-Welsch Q-test was used to compare the raw means of the levels from the fixed effects.

\subsection{Results}

\subsubsection{Embryo development}

Development of embryos cultured in groups from Day- 1 to Day- 6 can be observed in Table 5.1. On Day-6, early blastocyst rates from oocytes cultured with FCS $(17.7 \pm 1.4)$ were higher than the ones from oocytes cultured without FCS $(6.3 \pm 1.4)(P=0.022)$. Individual development from Day-6 to Day-7 embryo is presented in Table 5.2. On Day-7, total blastocysts and expanded blastocyst rates were significantly higher in embryos from Day-6 early blastocyst than the ones from Day- 6 morula, both with and without FCS prior to Day-6 $(P<0.005)$. 
Table 5.1. Morula and early blastocyst rates on Day-6 after culture in mSOF $+6 \mathrm{mg} \mathrm{mL}^{-1}$ BSA in groups with or without $0.1 \%$ fetal calf serum (FCS).

\begin{tabular}{lcll}
\hline & & \multicolumn{2}{c}{ Day-6 (\%) } \\
\cline { 3 - 4 } FCS & $\boldsymbol{n}$ & Morula & Early blastocyst \\
\hline$(-)$ & 1133 & $40.9 \pm 1.5$ & $6.3 \pm 1.4^{\mathrm{x}}$ \\
$(+)$ & 908 & $38.3 \pm 1.5$ & $17.7 \pm 1.4^{\mathrm{y}}$ \\
\hline$P$ value & & 0.709 & 0.022
\end{tabular}

$n=$ number of fertilized oocytes cultured. Data from 7 replicates (LSM \pm s.e.m.). Superscripts ${ }^{x, y}$ express significant differences.

Table 5.2. In vitro development of Day- 6 morulae and early blastocysts produced in mSOF+ $6 \mathrm{mg} \mathrm{mL}^{-1}$ BSA in groups with or without $0.1 \% \mathrm{FCS}$, and after single culture without protein up to Day-7.

\begin{tabular}{llccc}
\hline & & \multicolumn{2}{c}{ Day-7 Blastocysts (\%) } \\
\cline { 3 - 5 } FCS & Day-6 stage & $\boldsymbol{n}$ & Total & Expanded \\
\hline$(-)$ & Early Blastocyst & 35 & $90.0 \pm 4.7^{x}$ & $53.1 \pm 4.6^{x}$ \\
$(-)$ & Morula & 242 & $59.2 \pm 4.7^{y}$ & $16.2 \pm 4.6^{y}$ \\
$(+)$ & Early Blastocyst & 96 & $94.0 \pm 4.7^{x}$ & $50.3 \pm 4.6^{x}$ \\
$(+)$ & Morula & 187 & $37.6 \pm 4.7^{y}$ & $7.6 \pm 4.6^{y}$ \\
\hline $\boldsymbol{P}$ value & & & $<0.005$ & $<0.005$
\end{tabular}

$n=$ number of Day- 6 morulae and early blastocysts cultured individually. Data from 7 culture replicates (LSM \pm s.e.m.). Superscripts ${ }^{x, y}$ express significant differences.

\subsubsection{In vitro survival to vitrification and warming}

After vitrification/warming, interaction between FCS and stage did not affect survival rates of Day-7 expanded blastocyst $(P>0.05)$, with $100 \%$ embryos surviving at $24 \mathrm{~h}$ in all treatments (Table 5.3). Interestingly, hatching rates of Day-7 embryos produced with FCS did not differ from embryos produced without FCS $(P>0.05)$. However, hatching rates at $24 \mathrm{~h}$ in EB-XB without FCS tended to be higher than in M-XB with FCS $(P=0.08)$. Such a tendency was not observed at $48 \mathrm{~h}$, with all groups showing comparable hatching rates. 
Table 5.3. In vitro survival after vitrification/warming of Day-7 bovine expanded blastocysts derived from morulae and early blastocysts produced in mSOF $+6 \mathrm{mg} \mathrm{mL}^{-1}$ BSA with or without $0.1 \%$ FCS from Day- 1 to Day- 6 after one-day single culture without protein.

\begin{tabular}{|c|c|c|c|c|c|c|c|}
\hline \multirow[b]{2}{*}{ Day-6 Stage } & \multirow[b]{2}{*}{ FCS } & \multirow[b]{2}{*}{ Day } & \multirow[b]{2}{*}{$n$} & \multicolumn{2}{|c|}{ Re-expanded (\%) } & \multicolumn{2}{|c|}{ Hatched (\%) } \\
\hline & & & & $24 \mathrm{~h}$ & $48 \mathrm{~h}$ & $24 \mathrm{~h}$ & $48 \mathrm{~h}$ \\
\hline $\begin{array}{l}\text { Early } \\
\text { blastocyst }\end{array}$ & $(-)$ & 7 & 30 & $100.0 \pm 4.9$ & $93.2 \pm 8.9$ & $58.3 \pm 10.5$ & $53.0 \pm 14.6$ \\
\hline Morula & $(-)$ & 7 & 57 & $100.0 \pm 4.1$ & $84.6 \pm 7.4$ & $30.6 \pm 8.7$ & $50.2 \pm 12.2$ \\
\hline $\begin{array}{l}\text { Early } \\
\text { blastocyst }\end{array}$ & $(+)$ & 7 & 67 & $100.0 \pm 4.5$ & $92.3 \pm 8.2$ & $31.8 \pm 9.6$ & $51.3 \pm 13.5$ \\
\hline Morula & $(+)$ & 7 & 26 & $100.0 \pm 4.6$ & $90.8 \pm 8.3$ & $28.1 \pm 9.7$ & $47.8 \pm 13.6$ \\
\hline
\end{tabular}

\subsubsection{Apoptosis and total cell numbers}

Total cell number and TUNEL-positive apoptosis percentage are shown in Fig.

5.2a with illustrative photomicrographs in Fig. 5.2b. Total cell numbers of hatched blastocysts after vitrification/warming were not affected by $0.1 \%$ FCS $(P>0.05)$, or by embryonic stage on Day-6 $(P>0.05)$. In contrast, FCS supplementation reduced cell counts in fresh expanded blastocysts examined in the lipid quantification study $(+F C S: 109.3 \pm 3.5$ vs. - FCS: $119.4 \pm 3.2 ; \mathrm{P}=$ 0.02). FCS supplementation and embryonic stage on Day-6 did not affect either apoptosis rates of hatched blastocysts after vitrification/warming $(P>0.05)$. 
(a)
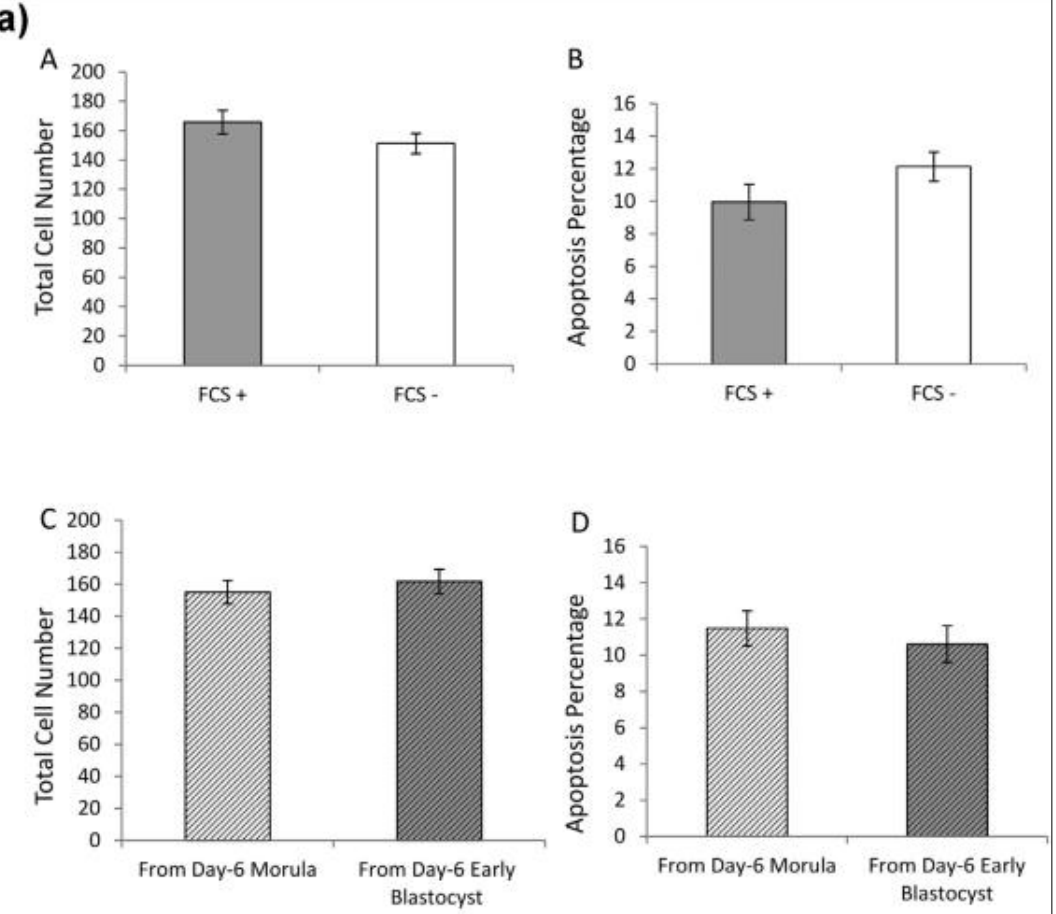

(b)
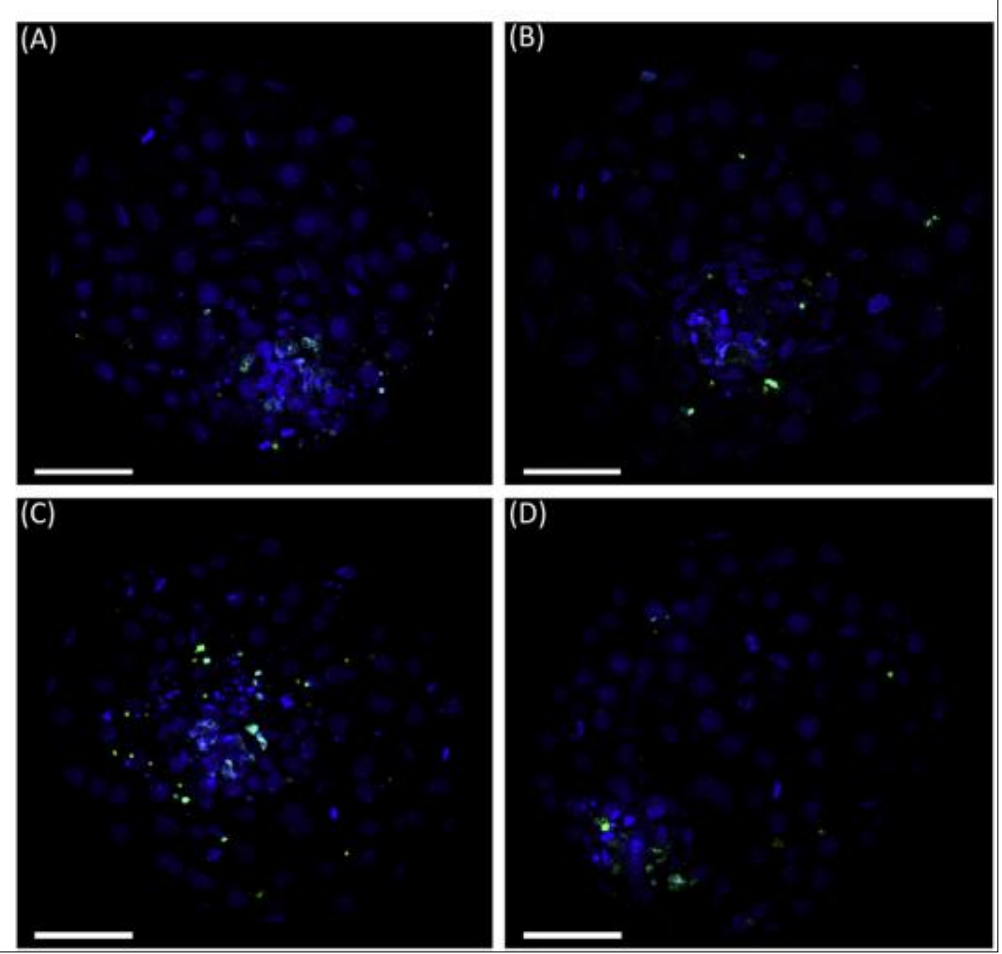

Fig. 5.2. (a) Effects of serum (FCS) in culture up to Day-6 and developmental stage (i.e., morula or early blastocyst) on Day-6, on total cell numbers $(A, C)$ and apoptosis percentages (B, D) within hatched blastocysts surviving in culture after vitrification/warming of Day-7 expanded blastocysts. (b) Representative photomicrographs of single Z-axis confocal section of hatched blastocysts after vitrification/warming of expanded blastocysts produced in mSOF $+6 \mathrm{mg} \mathrm{mL}^{-1}$ BSA with FCS up to Day-6 (A) or without FCS up to Day-6 (B), and after one-day single culture without protein from Day-6 morula (C) or from Day-6 early blastocyst (D). Images showing TUNEL-positive cells in green and nuclear DAPI staining in blue. Scale bar $50 \mathrm{~mm}$. 


\subsubsection{Lipid quantification study}

Intracellular LD accumulation on Day-7 expanded blastocysts was higher with FCS than without FCS $(84.5 \pm 4.0$ vs. $64.4 \pm 3.6$, respectively; $P=0.0002)$ (Fig. 5.3a). The embryonic stage on Day-6 affected cell counts and LD of Day-7 expanded blastocysts. Thus, M-XB showed higher cell counts than EB-XB $(P=$ $0.01)$, and LD per cell in $M-X B$ were more abundant than in EB-XB $(P=0.03)$.

Fig. 5.3b shows $3 \mathrm{D}$ reconstructions from the confocal datasets that illustrate the LD distribution by size. When LD were arranged by size, FCS increased numbers of small, medium and large LD on Day-7 expanded blastocysts $(P<$ 0.01). However, M-XB showed more medium and large LD per cell $(P<0.02$ and $P<0.0004$, respectively) than EB-XB. In the absence of FCS, EB-XB showed the highest cell counts $(P<0.05)$. As expected, Day-6 morula showed lower cell counts than the number of cells counts in the Day-7 expanded blastocyst different groups $(P<0.05)$. However, cell counts in Day-6 morula were similar, regardless of the embryos having been cultured in the presence or in the absence of FCS. Interestingly, Day-6 morulae cultured with FCS showed more total LD per cell than all other embryonic stages and conditions analyzed on days 6 and $7(P<0.001)$. In addition, Day- 6 morulae cultured with FCS contained smaller LD than all the types of Day-7 expanded blastocysts analyzed $(P<0.001)$. However, the amounts of medium and large LD were similar between Day-6 morulae cultured with and without FCS and all types of Day-7 expanded blastocysts. 


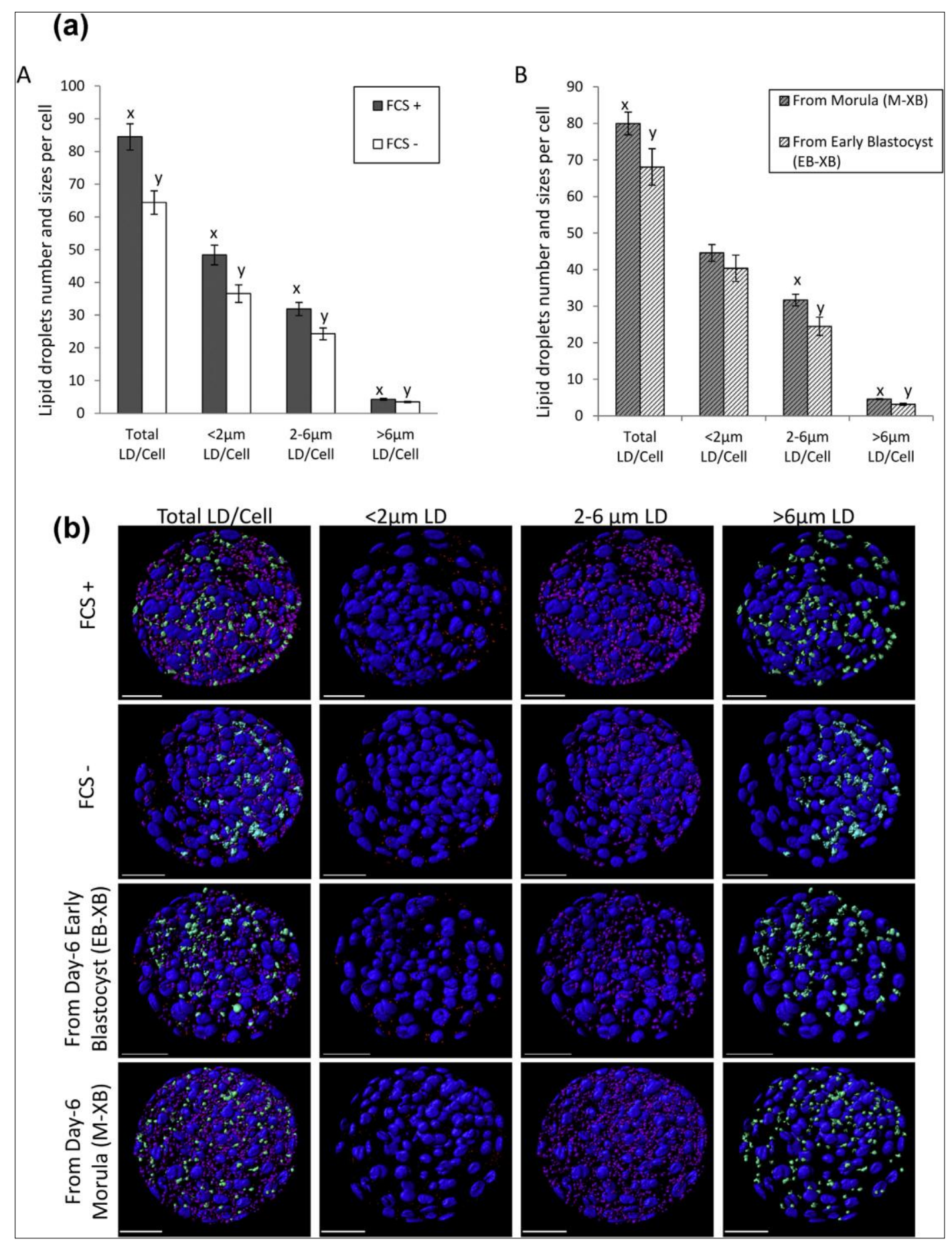

Fig. 5.3. (a) Lipid droplets number and sizes per cell counted in fresh expanded blastocysts from culture with FCS up to Day-6 (A; FCS +) or without FCS up to Day-6 (A; FCS-), from Day-6 morula $(B ; M-X B)$ or from Day-6 early blastocyst $(B ; E B-X B)$. LSM \pm s.e.m. $(x, y): P<0.03$. (b) Representative three-dimensional reconstructions (frontal view) of confocal datasets showing lipid droplets stained with Nile Red in fresh expanded blastocysts produced in mSOF + $6 \mathrm{mg} \mathrm{mL}^{-1}$ BSA with FCS up to Day-6 (FCS +) or without FCS up to Day-6 (FCS-), and after one-day single culture without protein from Day-6 morula (M-XB) or from Day- 6 early blastocyst (EB-XB). Lipid droplets (LD) have been pseudocoloured according to their size: $<2 \mathrm{~mm}$ (red), 2$6 \mathrm{~mm}$ (purple), >6 mm (green). Nuclei were stained with DAPI (blue). Scale Bars: $50 \mathrm{~mm}$. 


\subsubsection{Embryo transfer and pregnancies}

A first ET trial with Day-7 fresh and vitrified/warmed blastocysts (blastocyst and expanded blastocyst) transferred to recipients can be observed in Table 5.4. Day-7 blastocysts transferred were obtained from culture with or without FCS up to Day-6, followed by selection of morula, early blastocyst or blastocyst stage to one-day single culture without protein. Pregnancies were monitored on Day-40 and Day-60. Preliminary results showed that pregnancies were recorded at all stages analyzed, regardless of the stage on Day-6 (morula, early blastocyst or blastocyst) or the culture medium used up to Day-6 (with or without FCS).

Table 5.4. Descriptive Day-40 and Day-60 pregnancy status of heifers transferred with embryos cultured from Day- 1 to Day- 6 in mSOF $+6 \mathrm{mg} \mathrm{mL}^{-1}$ BSA, with or without $0.1 \%$ FCS and after one-day single culture without protein.

\begin{tabular}{|c|c|c|c|c|c|c|}
\hline $\begin{array}{l}\text { Culture media from } \\
\text { Day-1 to Day-6 }\end{array}$ & $n$ & $\begin{array}{l}\text { Day-6 } \\
\text { Stage }\end{array}$ & $\begin{array}{l}\text { Day-7 } \\
\text { Stage }\end{array}$ & $\begin{array}{c}\text { Status at } \\
\text { ET }\end{array}$ & $\begin{array}{c}\text { Day-40 } \\
\text { Pregnancy }\end{array}$ & $\begin{array}{c}\text { Day-60 } \\
\text { Pregnancy }\end{array}$ \\
\hline \multirow{6}{*}{$\mathrm{FCS}+\mathrm{BSA}$} & 3 & $M$ & $B$ & $F$ & $2 / 3$ & $2 / 3$ \\
\hline & 2 & $M$ & XB & $\mathrm{F}$ & $2 / 2$ & $2 / 2$ \\
\hline & 2 & $\mathrm{M}$ & XB & V & $1 / 2$ & $1 / 2$ \\
\hline & 1 & EB & B & $\mathrm{F}$ & $0 / 1$ & $0 / 1$ \\
\hline & 3 & EB & XB & $\mathrm{F}$ & $2 / 3$ & $2 / 3$ \\
\hline & 1 & $\mathrm{~B}$ & XB & $\mathrm{F}$ & $1 / 1$ & $1 / 1$ \\
\hline Total & 12 & & & & $8 / 12$ & $8 / 12$ \\
\hline \multirow[t]{7}{*}{ BSA } & 6 & $M$ & $B$ & $\mathrm{~F}$ & $1 / 6$ & $1 / 6$ \\
\hline & 2 & $M$ & XB & $\mathrm{F}$ & $1 / 2$ & $0 / 2$ \\
\hline & 2 & $M$ & XB & V & $1 / 2$ & $1 / 2$ \\
\hline & 1 & EB & B & V & $1 / 1$ & $1 / 1$ \\
\hline & 2 & EB & XB & $\mathrm{F}$ & $1 / 2$ & $1 / 2$ \\
\hline & 4 & EB & XB & V & $2 / 4$ & $2 / 4$ \\
\hline & 2 & B & XB & V & $1 / 2$ & $1 / 2$ \\
\hline Total & 19 & & & & $8 / 19$ & 7/19 \\
\hline
\end{tabular}

ET: embryo transfer; N: number of Day-7 ET; M: Morula; EB: Early Blastocyst; B: Blastocyst. XB: Expanded Blastocyst; F: Fresh; V: Vitrified/warmed.

\subsection{Discussion}

In this study we describe how in vitro embryo culture in the presence of a very low amount of FCS improves early blastocyst rates on Day-6, which leads, after 
single culture in absence of protein, to more expanded blastocysts on Day-7. The enrichment of $\mathrm{CM}$ with $0.1 \%$ FCS increased lipid accumulation in expanded blastocysts; however, their survival to vitrification/warming and their apoptosis rates were similar to BSA-produced embryos. Our previous results indicated that, only $10 \%$ of embryos reached the early blastocyst stage on Day- 6 , and the morula to expanded blastocyst development rates were lower without protein $[9,10]$. In this experiment, we improved early blastocyst rates by adding minute proportions of serum from Day-1 to Day-6, prior to protein removal. Thereafter, the early blastocyst stage on Day-6 led to increased yields of expanded blastocyst on Day-7, both with and without serum in culture. Our current study suggests that early blastocysts had lower substrate requirement than morulae in order to reach the expanded blastocyst stage. Post-compaction stages require more protein [34] and amino-acids [35] for their development than cleavage stages do. However, protein requirement seems to be strictly stage-dependent because early blastocysts develop and expand at high rates both with and without protein $[9,10]$. Kinetics studies in bovine embryos usually analyzed different stage endpoints, but not the same developmental endpoint reached by embryos that progressed from different earlier stages. Monitoring embryo development according to specific patterns appears to be more adequate than specific embryonic stages for selecting superior viability embryos [36]. Previous studies in our laboratory described the advantages of individual culture in simple medium [5-7] and how protein starvation improves embryonic viability $[9,10]$. Furthermore, one-day single culture without protein has allowed the identification of non-invasive and high accuracy embryonic sex biomarkers [8]. Supplementation of bovine embryo culture medium with serum, especially FCS, 
is quite frequent. Thus, several studies show that the presence of serum may inhibit early cleavage even though later development up to the blastocyst stage was accelerated [20,23,34]. In this work, cleavage rates were not affected when CM was supplemented with $0.1 \%$ FCS. In addition, the use of FCS allowed selecting more expanded blastocysts for vitrification on Day-7. The lipid fraction present in serum could be incorporated into developing embryos [32] and affect the quality of resulting blastocysts [37]. Interestingly, the presence of serum prior to Day-6 did not affect in vitro survival rates of Day-7 expanded blastocysts after vitrification/warming. In this way, $100 \%$ embryos re-expanded at $24 \mathrm{~h}$ in all treatment groups, eliminating the pre- transfer culture, a time consuming and costly operation. This is consistent with our previous observations of $98 \%$ of vitrified/ warmed embryos re-expanding at $24 \mathrm{~h}$ after single culture without protein from Day-6 onwards [9]. We also observed that Day-7 expanded blastocysts produced with FCS tended to show reduced hatching rates at $24 \mathrm{~h}$. Nevertheless, this can be interpreted as a delay, because similar hatching rates were observed in all treatment groups at $48 \mathrm{~h}$. Further experiments will be necessary to determine if the delayed hatching induced by FCS can impact pregnancy rates after ET with vitrified/warmed embryos. In cows, an important goal is to improve blastocyst rates of Day- 7 in vitro produced embryos. It is generally accepted that Day-7 embryos, particularly at the expanded blastocysts stage, show higher pregnancy rates than Day-8 embryos and/or earlier embryonic stages [38,39,11]. Moreover, when embryo vitrification is a requirement, the embryo transfer with $\mathrm{EB}-\mathrm{XB}$ results in calves with birthweight lower than M-XB [10], which avoids difficulties at birth and improves fetomaternal welfare. Apoptosis incidence in early embryos is an important parame- 
ter for evaluation of embryonic health [40,41]. In addition, Sudano et al. [27] observed that the incidence of apoptosis in embryonic cells strongly correlates with embryo survival after cryopreservation. Apoptosis controls cell quality by removing damaged, impaired, nonfunctional, or even excessive cells [42]. However, a disproportionate incidence of cell death is associated with a reduction of embryonic viability [41,43-45]. In this study, neither FCS supplementation nor Day-6 embryonic stage (i.e. Morula or early blastocyst) increased apoptosis rates of hatched blastocyst after vitrification/warming. It has been shown that serum supplementation increases embryonic cells number $[46,47]$, whereas others studies reported a reduction [43] of cells number. Although minimum numbers of embryonic cells are necessary for establishing pregnancy [48], the optimal cell amounts and distribution of inner cell mass and trophectoderm in the blastocyst are unclear. In this study, total cell counts in hatched blastocyst surviving vitrification/warming were unaffected by FCS supplementation or embryonic stage on Day-6. Interaction between FCS and embryonic stage did not affect lipid accumulation on Day-7 expanded blastocysts. However, FCS increased the numbers of intracellular LD and reduced cell counts on Day-7 expanded blastocysts. Cellular and molecular mechanisms of lipid accumulation in embryos produced in vitro are still poorly understood. However, reducing FCS concentration in culture was enough to decrease lipid contents and increase survival to cryopreservation [20]. In our previous experiments, we observed that the reduction in lipid contents typically observed in the transition from the morula to the expanded blastocyst stage in the presence of protein was more pronounced in the absence of protein. Therefore, both exogenous protein and Day-6 embryonic stage (i.e. Morula or 
early blastocyst) affected lipid contents as observed at the Day-7 expanded blastocyst stage [10]. In this study, the absence of FCS in culture medium reduced intracellular LD, and lipid accumulation was greater in the Day-6 morula stage than in later stages, as observed by Sudano et al. [49]. The increased lipid contents in embryos cultured with FCS can be due to any of the following mechanisms: (I) Absorption of lipoproteins presents in serum [50]; (II) Activation of neo-synthesis of triglycerides in embryonic cells [51]; and (III) Modification of b-oxidation inside the mitochondria [32]. Therefore, once the oxidation-reduction state is changed, mitochondrial metabolism becomes modified and b-oxidation of lipid complexes is impaired, leading to high lipid accumulation [32,52,53]. Interestingly, Day-6 embryonic stage affected lipid contents in the Day-7 expanded blastocyst stage. Day-7 expanded blastocysts exhibited increased LD accumulation when embryos were produced from Day-6 morula stage in contrast to early blastocyst. With the onset of morula compaction and during blastocyst formation, energy demands, measured as oxygen and nutrient consumption, increase dramatically. We proposed that, contrary to the blastocyst, the ability to use oxygen in the morula is still limited, which may hinder the lipid catabolism [10]. The heterogeneity of LD in size, location, and associated proteins within a given cell or tissue, and between different tissues, suggests that subpopulations of LD have most likely specialized functions in lipid storage and metabolism [54]. The differences in the LD sizes in bovine embryos produced in vitro have been previously described $[32,55,56,10]$. Lipogenesis associates with the smallest granules, which converge to form larger ones by different mechanisms [57]. Thus, FCS led to Day-6 morula containing larger amounts of small and total LD. The embryos 
produced with FCS accumulated high LD amounts up to Day-6, which could not be reduced after one-day protein removal to the same levels as embryos produced in BSA. Moreover, FCS supplementation increased total LD on Day-7 expanded blastocyst, regardless of LD sizes. Finally, in vitro embryos cultured with FCS $(0.1 \%)$ up to Day-6 have been transferred, and effective pregnancies were obtained. These preliminary results suggest that the presence of low FCS concentration prior to individual culture system on Day-6, is compatible with pregnancy under a variety of embryonic transitions in conditions that did not differ from BSA. Long-term effects of minimal concentration of serum will be evaluated in future studies. In conclusion, very low concentration of FCS allowed obtaining higher early blastocyst rates on Day-6, which, after one-day single culture without protein, led to improved expanded blastocyst rates. In terms of survival to cryopreservation, apoptosis rates and lipid contents, the quality of expanded blastocysts produced with FCS compares well with BSA. Even though long-term effects associated with birth weight and calf phenotype must be confirmed, our preliminary studies show that FCS do not reduces the viability of embryos to produce pregnancies. 


\subsection{References}

[1] Biggers JD. Reflections on the culture of the preimplantation embryo. Int J Dev Biol 1998; 42(7):879-84.

[2] Summers MC, Biggers JD. Chemically defined media and the culture of mammalian preimplantation embryos: historical perspective and current issues. Hum Reprod Update 2003; 9(6):557-82.

[3] Feugang JM, Camargo-Rodríguez O, Memili E. Culture systems for bovine embryos. Livest Sci 2009; 121(2):141-9.

[4] Goovaerts I, Leroy J, Jorssen E, Bols P. Noninvasive bovine oocyte quality assessment: possibilities of a single oocyte culture. Theriogenology 2010; 74 (9):1509-20.

[5] Muñoz M, Uyar A, Correia E, Díez C, Fernandez-Gonzalez A, Caamaño JN, et al. Prediction of pregnancy viability in bovine in vitro-produced embryos and recipient plasma with Fourier transform infrared spectroscopy. J Dairy Sci 2014; 97(9):5497-507.

[6] Muñoz M, Marquant-Le Guienne B, Fernandez-Gonzalez A, Díez C, Caamaño JN, Trigal B, et al. Metabolomic prediction of pregnancy viability in superovulated cattle embryos and recipients with fourier transform infrared spectroscopy. BioMed Res Int 2016; 2014.

[7] Muñoz M, Uyar A, Correia E, Díez C, Fernández-González A, Caamaño JN, et al. Non-invasive assessment of embryonic sex in cattle by metabolic fingerprinting of in vitro culture medium. Metabolomics 2014; 10:443-51.

[8] Gómez E, Muñoz M, Simó C, Ibáñez C, Carrocera S, Martín-González D, et al. Non-invasive metabolomics for improved determination of embryonic sex markers in chemically defined culture medium. J Chromatogr A 2016; 1474:138-44.

[9] Murillo-Ríos A, Maillo V, Muñoz M, Gutiérrez-Adán A, Carrocera S, MartinGonzález D, et al. Short- and long-term outcomes of the absence of protein during bovine blastocyst formation in vitro. Reprod Fertil Dev 2016, doi:http://dx.doi.org/10.1071/rd15485.

[10] Gómez E, Carrocera S, Uzbekova S, Martin D, Murillo A, Alonso- Guervos $M$, et al. Protein in culture and endogenous lipid interact with embryonic stages to alter calf birth weight after vitrification and warming. Reprod. Fertil. Dev 2016, doi:http://dx.doi.org/10.1071/RD16213 in press.

[11] Van Wagtendonk-de Leeuw AM, Aerts BJ, Den Daas JH. Abnormal offspring following in vitro production of bovine preimplantation embryos: a field study. Theriogenology 1998; 49(5):883-94. 
[12] Bonilla L, Block J, Denicol AC, Hansen PJ. Consequences of transfer of an in vitro-produced embryo for the dam and resultant calf. J Dairy Sci 2014; 97 (1):229-39.

[13] Hasler JF. In vitro culture of bovine embryos in Menezo's B2 medium with or without coculture and serum: the normalcy of pregnancies and calves resulting from transferred embryos. Anim Reprod Sci 2000; 60:8191.

[14] Xu J, Guo Z, Su L, Nedambale TL, Zhang J, Schenk J, et al. Developmental potential of vitrified Holstein cattle embryos fertilized in vitro with sex-sorted sperm. J Dairy Sci 2006; 89(7): 2510-8.

[15] Block J, Bonilla L, Hansen PJ. Effect of addition of hyaluronan to embryo culture medium on survival of bovine embryos in vitro following vitrification and establishment of pregnancy after transfer to recipients. Theriogenology 2009; 71(7): 1063-71.

[16] Gutiérrez-Adán A, Lonergan P, Rizos D, Ward FA, Boland MP, Pintado B, et al. Effect of the in vitro culture system on the kinetics of blastocyst development and sex ratio of bovine embryos. Theriogenology 2001; 55(5):1117-26.

[17] Holm P, Booth PJ, Callesen $\mathrm{H}$. Kinetics of early in vitro development of bovine in vivo-and in vitro-derived zygotes produced and/or cultured in chemically defined or serum-containing media. Reproduction 2002; 123:553-65.

[18] Rizos D, Gutierrez-Adán A, Perez-Garnelo S, De La Fuente J, Boland MP, Lonergan $P$. Bovine embryo culture in the presence or absence of serum: implication for blastocysts development, cryotolerance, and messenger RNA expression. Biol Reprod 2003; 68:236-43.

[19] Mucci N, Aller J, Kaiser GG, Hozbor F, Cabodevila J, Alberio RH. Effect of estrous cow serum during bovine embryo culture on blastocyst development and cryotolerance after slow freezing or vitrification. Theriogenology 2006; 65:1551-62.

[20] Sudano MJ, Paschoal DM, Rascado TS, Magalhães LCO, Crocomo LF, Lima-Neto JF, et al. Lipid content and apoptosis of in vitro-produced bovine embryos as determinants of susceptibility to vitrification. Theriogenology 2011; 75:1211-20.

[21] Pinyopummintr T, Bavister BD. Development of bovine embryos in a cell-free medium: effects of type of serum, timing of its inclusion and heat inactivation. Theriogenology 1994; 41: 1241-9.

[22] Lazzari G, Wrenzycki C, Herrmann D, Duchi R, Kruip T, Niemann H, et al. Cellular and molecular deviations in bovine in vitro produced embryos are related to the large offspring syndrome. Biol Reprod 2002; 67:767-75. 
[23] Gómez E, Rodríguez A, Muñoz M, Caamaño JN, Hidalgo CO, Morán E, et al. Serum free embryo culture medium improves in vitro survival of bovine blastocysts to vitrification. Theriogenology 2008; 69:1013-21.

[24] Del Collado M, Saraiva NZ, Lopes FL, Gaspar RC, Padilha LC, Costa R, et al. Influence of bovine serum albumin and fetal bovine serum supplementation during in vitro maturation on lipid and mitochondrial behavior in oocytes and lipid accumulation in bovine embryos. Reprod Fertil Dev 2015; 28 (11): 1721-32.

[25] Heras S, De Coninck DI, Van Poucke M, Goossens K, Pascottini OB, Van Nieuwerburgh $F$, et al. Suboptimal culture conditions induce more deviations in gene expression in male than female bovine blastocysts. BMC Genom 2016; 17(1):1.

[26] Mullaart E, Dotinga F, Ponsart C, Knijn H, Schouten J. 232 addition of very low amounts of serum (estrus cow serum) improves in vitro embryo production in dairy cattle. Reprod Fertil Dev 2015; 27:205-6.

[27] Sudano MJ, Paschoal DM, Silva Rascado T, Crocomo LF, Magalhães LC, Martins Junior $A$, et al. Crucial surviving aspects for vitrified in vitroproduced bovine embryos. Zygote 2012; 11:1-8.

[28] Sanches BV, Lunardelli PA, Cardoso BL, Colombo Pereira MH, Gaitkoski $D$, Basso AC, et al. A new direct transfer protocol for cryopreserved IVF embryos. Theriogenology 2016; 85(6):1147-51.

[29] Lindner GM, Wright RW. Bovine embryo morphology and evaluation. Theriogenology 1983; 20(4):407-16.

[30] Trigal B, Gómez E, Caamaño JN, Muñoz M, Moreno J, Carrocera S, et al. In vitro and in vivo quality of bovine embryos in vitro produced with sexsorted sperm. Theriogenology 2012; 78: 1465-75.

[31] Caamaño JN, Gómez E, Trigal B, Muñoz M, Carrocera S, Martín D, et al. Survival of vitrified in vitro-produced bovine embryos after a one-step warming in straw cryoprotectant dilution procedure. Theriogenology 2015; 83:881-90.

[32] Abe H, Yamashita S, Satoh T, Hoshi H. Accumulation of cytoplasmic lipid droplets in bovine embryos and cryotolerance of embryos developed in different culture systems using serum-free or serum-containing media. Mol Reprod Dev 2002; 61:57-66.

[33] Hidalgo CO, Gómez E, Prieto L, Duque P, Goyache F, Fernández L, et al. Pregnancy rates and metabolic profiles in cattle treated with propylene glycol prior to embryo transfer. Theriogenology 2004; 62:664-76. 
[34] Thompson JG, Allen NW, McGowan LT, Bell ACS, Lambert MG, et al. Effect of delayed supplementation of fetal calf serum to culture medium on bovine embryo development in vitro and following transfer. Theriogenology 1998; 49: 1239-49.

[35] Guerif F, McKeegan P, Leese HJ, Sturmey RG. A simple approach for consumption and release (CORE) analysis of metabolic activity in single mammalian embryos. PLoS One 2013; 8(8):e67834.

[36] Gutiérrez-Adán A, White CR, Van Soom A, Mann MR. Why we should not select the faster embryo: lessons from mice and cattle. Reprod Fertil Dev $2015 ; 27$ (5):765-75.

[37] Leroy J, Van Hoeck V, Clemente M, Rizos D, Gutierrez-Adan A, Van Soom $A$, et al. The effect of nutritionally induced hyperlipidaemia on in vitro bovine embryo quality. Hum Reprod 2010; 25(3):768-78.

[38] Randi F, Fernandez-Fuertes B, McDonald M, Forde N, Kelly AK, Bastos A, et al. Asynchronous embryo transfer as a tool to understand embryouterine interaction in cattle: is a large conceptus a good thing? Reprod Fertil Dev 2016; 28(12):1999-2006, doi:http://dx.doi.org/10.1071/RD15195.

[39] Kubisch HM, Sirisathien S, Bosch P, Hernandez-Fonseca HJ, Clements G, Liukkonen JR, et al. Effects of developmental stage: embryonic interferontau secretion and recipient synchrony on pregnancy rate after transfer of in vitro produced bovine blastocysts. Reprod Domest Anim 2004; 39(2):120-4.

[40] Gjorret JO, Knijin HM, Dieleman SJ, Avery B, Larsson LI, Hyttel M. Chronology of apoptosis in bovine embryos produced in vivo and in vitro. Biol Reprod 2003; 69:1193-200.

[41] Rodríguez A, Diez C, Ikeda S, Royo LJ, Caamaño JN, Alonso-Montes C, et al. Retinoids during the in vitro transition from bovine morula to blastocyst. Hum Reprod 2006; 21(8):2149-57.

[42] Hardy K. Cell death in the mammalian blastocyst. Mol Hum Reprod 1997; 3: 919-25.

[43] Byrne AT, Southgate J, Brison DR, Leese HJ. Analysis of apoptosis in the preimplantation bovine embryo using TUNEL. J Reprod Fertil 1999; 117:97-105.

[44] Fabian D, Koppel J, Maddox-Hyttel. Apoptotic processes during mammalian preimplantation development. Theriogenology 2005; 64(2):22131.

[45] Gómez E, Correia-Álvarez E, Caamaño JN, Díez C, Carrocera S, Peynot $\mathrm{N}$, et al. Hepatoma-derived growth factor: from the bovine uterus to the in vitro embryo culture. Reproduction 2014; 148(4):353-65. 
[46] Gardner DK, Pool TB, Lane M. Embryo nutrition and energy metabolism and its relationship to embryo growth, differentiation and viability. Semin Reprod Med 2000; 18:205-18.

[47] Van Langendonckt A, Donnay I, Schuurbiers N, Auquier P, Carolan C, Massip $A$, et al. Effects of supplementation with fetal calf serum on development of bovine embryos in synthetic oviduct fluid medium. $J$ Reprod Fertil 1997; 109 (1):87-93.

[48] Iwasaki S, Yoshiba N, Ushijima H, Watanabe S, Nakahara T. Morphology and proportion of inner cell mass of bovine blastocysts fertilized in vitro and in vivo. J. Reprod. Fertil. 1990; 90:279-84.

[49] Sudano MJ, Rascado TDS, Tata A, Belaz KRA, Santos VG, Valente RS, et al. Lipidome signatures in early bovine embryo development. Theriogenology doi:http://dx.doi.org/10.1016/j.theriogenology.2016.03.025.

2016,

[50] Sata R, Tsuji H, Abe H, Yamashita S, Hoshi H. Fatty acid composition of bovine embryos cultured in serum free and serum-containing medium during early embryonic development. J Reprod Dev 1999; 45: 97-103.

[51] Razek IAE, Charpigny G, Kodja S, Marquant-Leguienne B, Mermillod P, Guyader $\mathrm{J}$, et al. Differences in lipid composition between in vivo- and in vitro-produced bovine embryos. Theriogenology 2000; 53:346.

[52] Barceló-Fimbres M, Seidel Jr. GE. Effects of either glucose or fructose and metabolic regulators on bovine embryo development and lipid accumulation in vitro. Mol Reprod Dev 2007; 74:1406-18.

[53] Barceló-Fimbres M, Seidel GE. Effects of fetal calf serum, phenazine ethosulfate and either glucose or fructose during in vitro culture of bovine embryos on embryonic development after cryopreservation. Mol Reprod Dev 2007; 74:1395-405.

[54] Ducharme NA, Bickel PE. Minireview: lipid droplets in lipogenesis and lipolysis. Endocrinology 2008; 149(3):942-9.

[55] Barceló-Fimbres M, Seidel Jr. GE. Cross-validation of techniques for measuring lipid content of bovine oocytes and blastocysts. Theriogenology 2011; 75 (3):434-44.

[56] Ghanem N, Ha AN, Fakruzzaman M, Bang JI, Lee SC, Kong IK. Differential expression of selected candidate genes in bovine embryos produced in vitro and cultured with chemicals modulating lipid metabolism. Theriogenology 2014; 82:238-50.

[57] Thiam AR, Farese Jr. RV, Walther TC. The biophysics and cell biology of lipid droplets. Nat Rev Mol Cell Biol 2013;14: 775-86. 


\section{6 | CAPÍtULO IV}

Hepatoma-derived growth factor: Protein quantification in uterine

fluid, gene expression in endometrial-cell culture and effects on in vitro embryo development, pregnancy and birth

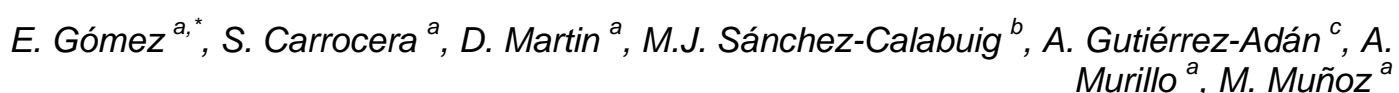

${ }^{a}$ Genética y Reproducción Animal, Centro de Biotecnología Animal, SERIDA, Camino de Rioseco, 1225, 33394 Gijón, Spain

${ }^{b}$ Facultad de Veterinaria, Departamento de Medicina y Cirugía Animal, Universidad Complutense, Av. Puerta de Hierro, s/n, 28040 Madrid, Spain

${ }^{c}$ Departamento de Reproducción Animal, INIA Avda. Puerta de Hierro, no12, local

10, 28040 Madrid, Spain

Theriogenology 2017. 96, 118-125

Project support was provided by the Spanish Ministry of Economy and Competitiveness MINECO-, projects AGL2016-78597-R and AGL2015-66145-R. Principado de Asturias, Plan de Ciencia, Tecnología e Innovación 2013-2017 (GRUPIN 14-114) and FEDER. AM was supported by Secretaría Nacional de Educación Superior, Ciencia, Tecnología e Innovación -Ecuador - II Fase 2013. The authors are members of the COST Action 16119, In vitro 3-D total cell guidance and fitness (Cellfit). 


\section{Abstract}

Hepatoma-derived growth factor (HDGF) is present in the endometrium of cows and other mammals. Recombinant HDGF (rHDGF) improves bovine blastocyst development in vitro. However, specific culture conditions and essential aspects of HDGF uterine physiology are yet unknown. In this work we quantified total HDGF protein in uterine fluid (UF) by multiple reaction monitoring (MRM), and analyzed effects of rHDGF on specific embryonic stages with Day- 6 bovine embryos cultured in vitro with and without BSA, and on pregnancy viability and calf phenotypes after embryo transfer to recipients. In addition, mRNA abundance of HDGF in endometrial cells co-cultured with one male or one female embryo was quantified. In the presence of BSA, rHDGF had no effect on blastocyst development; however, in BSA-free culture rHDGF mainly promoted development of early blastocysts in contrast with morulae. As the presence of HDGF contained in commercial BSA replacements was suspected, western blot confirmed HDGF identification in BSA both with and without fatty acids. Total HDGF quantified by MRM tended to increase in UF without vs. UF with embryos $(P=0.083)$. Pregnancy and birth rates, birth weight and calf measurements did not differ between embryos cultured with rHDGF and controls without rHDGF. However, HDGF abundance in cultured epithelial, endometrial cells tended to increase $(P<0.08)$ in culture with one male embryo. rHDGF acts selectively on specific embryonic stages, but care should be taken with specific macromolecular supplements in culture. The endometrial expression of HDGF can be regulated by the embryonic sex. The use of rHDGF is compatible with pregnancy and birth of normal calves. 


\subsection{Introduction}

Growth factors (GFs) produced by the reproductive tract can improve in vitro bovine embryo development, and/or often pregnancy rates and survival to term. Reports include Dickkopf, epidermal growth factor, insulin-like growth factor 1, granulocytemacrophage colony-stimulating factor, hyaluronan, fibroblast growth factor 2, activin, and platelet-activating factor [1-9]. Hepatoma-derived growth factor (HDGF) is a 240 amino-acid protein isolated from supernatants of human hepatoma cells in culture [10]. Surface expressed nucleolin has recently been identified as a HDGF receptor [11], and HDGF stimulates cell proliferation in fibroblasts, endothelial cells and hepatoma cells [12]. In the cow, HDGF is resent in the endometrium and uterine fluid (UF) during early pregnancy $[13,14]$, as well as in the endometrium and conceptus in horses [15] and in the UF of the tammar wallaby [16]. Interestingly, in cattle, changes induced in the uterine HDGF by embryos [13] are not reflected as mRNA transcription and protein abundance in endometrial cells [14] by which up-regulation of HDGF in UF could be dependent on post-transcriptional modifications, as previously postulated to occur in the uterus [17]. Notably, unlike the absence of detectable transcription in response to embryos in vivo, cultured endometrial cells transcribe in vitro in response to one embryo [18]. Recombinant HDGF ( $r$ HDGF) improves blastocyst development and cell proliferation [14]. HDGF may act by both autocrine and paracrine mechanisms to promote early embryo development, and effects of rHDGF are strictly time and/or stage dependent (i.e. it stimulates embryo growth within Day-6 but not Day-5 morulae) [14]. Within in vitro embryo culture, similar stage- or time-dependent effects also occur with other GFs, resulting in altered blastocyst development and quality 
$[6,7,19,20]$ and, ultimately, improved pregnancy and birth rates $[1,20]$. In cultures with synthetic oviduct fluid (SOF), vitrified/warmed, Day-7 expanded blastocysts resulting of Day-6 morulae or early blastocysts deprived of protein yield lower miscarriage and improved birth rates upon transfer to recipients [21]. Interestingly, Day-6 morulae and early blastocysts mobilize lipid stocks differently in response to protein deprivation, and the Day- 6 early blastocysts stage yields lighter calves than Day-6 morula when their cognate Day-7 vitrified expanded blastocysts are transferred [22]. Therefore, r-HDGF in culture could exert different stimulation on morulae and/or early blastocysts. Protein supplements used in bovine embryo culture are normally impure and can induce confounding effects when testing single molecules. Serum and its extracts, as bovine serum albumin (BSA), may carry GFs, cytokines, aminoacids, steroids and a variety of contaminants [23]. Cold-precipitated BSA exists as an embryo tested product, and more refined forms of BSA (e.g., essentially fatty-acid free -FAF-) are also used in embryo culture. Effects of exogenously added GFs can be masked not only by serum or its extracts, but also by autocrine and paracrine interactions (group embryo culture). The effects of HDGF on in vitro embryo culture were demonstrated both in group and single culture in chemically defined conditions [14], but it is unknown yet whether culture in medium with BSA would offer similar performance. Endometrial cells are responsive to embryonic sex early in development in vivo [24]. Therefore, endometrial HDGF could also show a sexually dimorphic transcription.

The objectives of this work were: 1) Total quantification of HDGF protein in UF by MRM, a technique that can be programmed to recognize peptides typically present in any protein isoform [25]; 2) Identifying the developmental effects of 
rHDGF on specific embryonic stages, both in semi-defined (BSA) conditions and in chemically defined conditions; 3) Analyzing the presence of HDGF in commercial BSA and BSA-FAF extracts used in embryo culture; 4) Analyzing endometrial transcription for HDGF in response to one male or female embryo in cultured endometrial cells; and 5) Determining whether embryos produced with rHDGF can establish pregnancy and reach birth with production of normal calves.

\subsection{Material and Methods}

All experimental procedures were approved by the Animal Research Ethics Committee of SERIDA (Agreement 02/02/2012), in accordance with the European Community Directive 86/609/EC. Ovaries were collected from cows slaughtered in commercial abattoirs (Matadero de Leon and Matadero de Guarnizo -Cantabria-, mostly for Holstein ovaries, and Matadero de Tineo, for Asturiana de los Valles ovaries (Spain). Ovaries were transported to the laboratory in $\mathrm{NaCl}$ solution $\left(9 \mathrm{mg} \mathrm{mL}^{-1}\right.$ ) with streptomycin sulfate, $100 \mathrm{mg} \mathrm{ml}^{-1}$, penicillin, $100 \mathrm{IU} \mathrm{mL}^{-1}$ and maintained at 25-30 ${ }^{\circ} \mathrm{C}$. All reagents were purchased from SIGMA (Madrid, Spain) unless otherwise stated.

\subsubsection{Embryo production}

In vitro-produced (IVP) embryos were obtained as described [26] with minor modifications. Antral follicles (3-8 $\mathrm{mm}$ in diameter) were aspirated through an 18-g needle connected to a syringe. Aspirated fluid was expelled into dishes containing holding medium (HM) TCM199 (Invitrogen, Barcelona, Spain), 25 $\mathrm{mM}$ HEPES and BSA $0.4 \mathrm{~g} \mathrm{~L}^{-1}$, and oocytes were searched under 
stereomicroscope. Oocytes with more than three layers of compact cumulus cells with homogenous cytoplasm were selected. For in vitro maturation (IVM), cumulus oocyte complexes (COCs) were washed twice in maturation medium (MM) consisting of TCM199 NaHCO3 $\left(2.2 \mathrm{~g} \mathrm{~L}^{-1}\right)$ supplemented with $10 \%(\mathrm{v} / \mathrm{v})$ fetal calf serum, 1:5 mg mL ${ }^{-1}$ of porcine FSH-LH (Stimufol; ULg FMV, Liege, Belgium) and $1 \mathrm{mg} \mathrm{mL}^{-1} 17$ b-estradiol. COCs were cultured $(\mathrm{n}=30-50)$ into a four-well dish with $500 \mathrm{~mL}$ of IVM medium for $22-24 \mathrm{~h}$ at $38.7^{\circ} \mathrm{C}$ under $5 \% \mathrm{CO}^{2}$ with saturated humidity.

After IVM, oocytes were subjected to in vitro fertilization (IVF; Day 0) with frozen/thawed sex-sorted or non sex-sorted spermatozoa from Holstein or Asturiana de los Valles breeds following described procedures [26,27], respectively. For experiments entirely in vitro or for transient embryo transfer to the uterus (Day-6 to Day-8), IVF was performed with non-sorted spermatozoa from a single bull. However, for transfer to recipients for pregnancy, embryos were produced from oocytes both from slaughterhouse ovaries or collected by Ovum-Pick-Up (OPU) following described procedures [28], and fertilized with non sorted ( $\mathrm{N}=3$ bulls) and female sex-sorted spermatozoa ( $\mathrm{N}=3$ bulls). COCs were washed three times in $\mathrm{HM}$ in four-well culture dishes containing pre-equilibrated fertilization medium (Fert-TALP) with heparin (10 mg mL $\mathrm{mb}^{-1}$; Calbiochem, La Jolla, CA, USA). For IVF, oocytes and sperm cells were incubated together for $18-20 \mathrm{~h}$ at $38.7 \stackrel{\circ}{\circ} \mathrm{C}$ in an atmosphere of $5 \% \mathrm{CO}_{2}$ with saturated humidity. Subsequently, cumulus cells were detached using a vortex, and presumptive zygotes were cultured in modified synthetic oviduct fluid (mSOF) containing amino acids (BME Amino Acids Solution), $45 \mathrm{~mL} \mathrm{~mL}^{-1}$ and MEM Non-essential amino-acid Solution (SIGMA, Madrid, Spain), $5 \mathrm{~mL} \mathrm{~mL}^{-1}$ ), 
citrate, myo-inositol, and BSA (6 g L'-1), as previously described [21]. Until Day6 , embryos were cultured in groups $(\mathrm{N}=35-45)$ in droplets of $\mathrm{mSOF}(1-2 \mathrm{~mL}$ per embryo) layered down mineral oil. In vitro culture was carried out at $38.7^{\circ} \mathrm{C}$, $5 \% \mathrm{CO}_{2}, 5 \% \mathrm{O}_{2}$ and saturated humidity. After Day- 6 embryos were cultured singly using different procedures as described below.

\subsubsection{Vitrification of embryos for transfer}

Vitrification procedures have been described in detail [26]. Briefly, Day-7 excellent expanded blastocysts were vitrified in two steps with fibre-plugs (CryoLogic Vitrification Method; CVM). Vitrification solutions contained DMSO, ethylene-glycol, and sucrose. Samples were vitrified by touching the surface of a chilled block placed in $\mathrm{LN}_{2}$ with the fibre plug hook that carried the drop with the embryo. Embryos were warmed by direct immersion of the fibre plug end in sucrose solution in one-step [29]. Subsequently, embryos were washed twice in Embryo Preservation Medium (IMV Technologies, France) and loaded in straws for transfer to recipients. In vitro development of vitrified/warmed embryos cultured with and without protein was already reported [21].

\subsubsection{Animals and embryo transfer (ET) for uterine fluid collection}

Detailed procedures were described [13]. Briefly, cyclic Holstein heifers $(N=14)$ were synchronized in estrus with an intravaginal progestagen device combined with a prostaglandin analogue. Day 0 was considered a fixed time $48 \mathrm{~h}$ after progestagen removal, in coincidence with the IVF onset in the laboratory. Day-6 IVP embryos ( $n=50$ ), or vehicle (Sham transfer) were transferred into the uteri 
of each estrus synchronized Holstein heifer $(n=14)$ at non consecutive cycles under epidural anesthesia.

On day 8, prior to being flushed, recipients were monitored to verify the presence of a corpus luteum in the expected ovary. Uterine flushings were performed using silicon Foley catheters loaded to flush the two cranial thirds of the horn ipsilateral to the corpus luteum. All recipients were first flushed with 45 $\mathrm{mL}$ PBS. Recovery of diluted uterine fluid (UF) was performed by aspirating with a $50 \mathrm{~mL}$ syringe (Becton-Dickinson, Zaragoza, Spain), only while a steady flow could be achieved. If embryos were transferred, the flushed fluids were directly filtered through an Em-Com device in order to retain the embryos, while the outlet fluid was collected in a tube and directly added with $10 \mathrm{~mL} \mathrm{~mL}^{-1}$ protease inhibitor (Protease Arrest; GE Healthcare, Madrid, Spain). Those recipients transferred with embryos were next extensively flushed with PBS $+1 \mathrm{mg} \mathrm{mL}^{-1}$ polyvinyl-pyrrolidone (PVP; mw 40000; P0930). Embryos were identified using a stereomicroscope and rapidly separated from fluids to be used in other experiments. Collected UF with embryos contained on average $n=43.1 \pm 5.2$ total and $n=34.1 \pm 3.7 \%$ viable embryos (as proportions of transferred morulae). UF was centrifuged $(2000 \mathrm{~g})$ at $4 \stackrel{\circ}{ } \mathrm{C}$, aliquoted and stored at $-145^{\circ} \mathrm{C}$. Concentrations of $\mathrm{P} 4$ lower than $2.0 \mathrm{ng} \mathrm{mL}^{-1}$ on Day- 0 and higher than $3.5 \mathrm{ng}$ $\mathrm{mL}^{-1}$ on Day-6 and Day-8 were recorded in all animals whose UFs were collected for analysis.

\subsubsection{Animals and embryo transfer for pregnancy and birth}

Detailed procedures were described [30]. Briefly, Holstein and Asturiana de los Valles heifers were synchronized in estrus by using an intra-vaginal 
progestagen device (PRID Alpha) for 10 days combined with a PG analogue (Dynolitic, Pfizer, Madrid, Spain) injected $48 \mathrm{~h}$ before progestagen removal. Prior to transfer, Day-7 expanded blastocysts that had been vitrified at 170-172 h PI were warmed and allowed to re-expand for 1-2 h in vitro. On cycle Day 7 (225 $\pm 1.5 \mathrm{~h}$ after progestagen removal; fixed time) blastocysts were nonsurgically transferred to recipients into uterine horn ipsilateral to $\mathrm{CL}$ under epidural anesthesia. Pregnancy was diagnosed on Day 40 and on Day 62; birth rates were monitored in recipients that were made pregnant after 1 to 4 ETs. At birth, body weight $(\mathrm{BW})$, height at withers $(\mathrm{HW})$, thorax circumference (TC), gestation length (GL) and daily weight (BW/GL), were recorded in the calf; BW was also measured in the mother. Plasma P4 was measured on Day 0 and Day 7 (5e6 $\mathrm{h}$ before ET) in blood samples taken up into EDTA vacuum tubes via coccygeal vein puncture. An ELISA test operating on a $0 \mathrm{e} 40 \mathrm{ng} / \mathrm{mL}$ scale (DRG Diagnostics, Marburg, Germany) was used. The test was sensitive starting from $0.5 \mathrm{ng} \mathrm{mL}^{-1}$ and cross-reactivity from steroids other than $\mathrm{P} 4$ was less than $1 \%$. Intra- and inter-assay coefficients of variation were $6 \%$ and $7 \%$, respectively.

\subsubsection{Multiple reaction monitoring (MRM) for HDGF contents in uterine}

\section{fluid}

HDGF abundance in UF was analyzed in UF collected on Day-8 by programming peptides to evaluate total protein content by multiple reaction monitoring (MRM). Samples of UF were concentrated, and protein was precipitated and suspended in ammonium bicarbonate. Protein (20 mg) was reduced with DTT, trypsin-digested and desalted. Five proteotypic peptides for HDGF were selected with MRM Pilot software (ABsciex), with 5 transitions 
programmed for each peptide. A control, unrelated synthetic peptide was spiked as an internal standard. The sequences of the 5 selected peptides did not include phosphorylable residues (Table 6.1), as reported in Uniprot for human HDGF (i.e. excluding coverage of serine (S): 135, 133, 165, 199; 202, 206, 238 and threonine $(\mathrm{T}): 184,200$ residues).

Table 6.1. Sequence of peptides from bovine hepatoma-derived growth factor detected in the multiple reaction monitoring study and their position in the protein.

\begin{tabular}{cc}
\hline Bovine peptide sequence & Amino acid position \\
\hline C*GDLVFAK & $12-19$ \\
ASGYQSSQK & $97-105$ \\
LVIDEPTK & $139-146$ \\
EAEDLEGEEK & $171-180$ \\
GPPQEEEEEEEEEEAAKE & $209-226$ \\
\hline
\end{tabular}

The area of the larger transition for the control peptide was used to normalize the area values of each other peptide. Peptides used to calculate relative protein concentration were evaluated for signal to noise ratio, reproducibility and validated with synthetic peptides. MRM experiments were performed on a 5500 QTRAP hybrid triple quadrupole/linear ion trap mass spectrometer (ABsciex) equipped with an Eksigent 1D p plus nanoLC chromatographic system. Data analysis was performed with Analyst 1.5.2 and MultiQuant 2.0.2 software (ABsciex). The area of most abundant transition for each analyzed peptide was used for relative quantitation.

\subsubsection{Identification of HDGF in BSA supplements by western blot}

Two types of BSA used in embryo culture were tested for the presence of HDGF. BSA A-3311, (batch no. 089K14281V, embryo culture tested), and BSA fatty-acid free (A-6003; batch SLBD6158V; >96\% fatty-acid free). Immunoblotting was performed as described previously [13]. Briefly, 2.5 $\mathrm{mg} / \mathrm{sample}$ was electrophoresed on $12 \%$ SDS-PAGE gels. Proteins were then 
transferred electrically onto a PVDF membrane (Millipore, Billerica, MA, USA), which was incubated with a mouse polyclonal antibody against human HDGF (predicted to work with bovine according to supplier; Abcam 43668; diluted 1:1500). After washing, the membrane was incubated with the required secondary antibody (goat antimouse/ HRP conjugate, NA931-1ML; Amersham Pharmacia Biotech) at 1:4000 dilution and detected using the Pierce ECL detection kit (Thermo Scientific, Waltham, MA, USA). Protein levels were not quantified.

\subsubsection{Endometrial cell and embryo co-culture}

Endometrial cells were obtained from early estrus cycle slaughterhouse uteri from heifers as described [18]. Briefly, ipsilateral uterine horns were excised, washed with $70 \%$ ethanol and cultured with $0.75 \%$ EDTA in PBS at $37^{\circ} \mathrm{C}$ during 60min. Epithelial cells (EC) and stromal cells (SC) were collected separately.

For EC collection, the horn was longitudinally excised and the inner surface scrapped. Cells were collected in DMEM-F12 (D8437) with 10\% FCS and antibiotics, and incubated for $3 \mathrm{~h}$. Subsequently, the cell mixture was centrifuged $8 \mathrm{~min}$ at $150 \mathrm{~g}$, and the pellet was washed before seeding in cellculture inserts $1.0 \mathrm{mM}$ pore size, $6.5 \mathrm{~mm}$ in diameter (Millipore, Madrid, Spain) coated with diluted Matrigel (1:2) in DMEM-F12. Cells were observed daily and the first renewal was performed at $48 \mathrm{~h}$ or $72 \mathrm{~h}$, depending on cell growth rate monitored. Subsequent renewals were performed every $48 \mathrm{~h}$ after the first renewal. 
For SC collection, endometrial tissue strips were minced and digested in $0.5 \%$ collagenase (C5138) in DMEM/F12 for $3 \mathrm{~h}$. The suspension was filtered through a $250 \mathrm{mM}$ mesh and subsequently through a nylon $30 \mathrm{mM}$ Millipore filter. The filtered samples were centrifuged $8 \mathrm{~min}$ at $150 \mathrm{~g}$, and re-suspended in $5 \mathrm{~mL}$ DMEM/F12 with 10\% FBS and antibiotics. Cells were seeded in the basal compartment of 24-well plates. Culture medium was renewed first after $18 \mathrm{~h}$ culture and subsequently every $48 \mathrm{~h}$.

For embryo-endometrial co-culture, EC cultures in inserts were placed in 24well plates onto SC cultures. Only replicates with 100\% confluence within SC and $>90 \%$ confluence in EC 7 days after seeding where selected for embryo coculture. Prior to embryo loading in EC, the cells were washed and cultured with serum-free TCM-199. One Day-6 IVP morula was loaded in the apical side of the EC, and co-cultures were maintained in serum free TCM-199 medium for 48 h. At the end of the co-culture period, the embryos were assessed for development stage and morphology and sexed by amelogenin gene amplification [31]. After removing culture medium, EC and SC were collected for gene expression.

\subsubsection{Gene expression of HDGF in epithelial and stromal endometrial cell cultures}

Procedures have been described [18]. Briefly, EC in inserts and SC in basement 12-well plates were collected after 8 days of culture. Cells were extracted with Trizol (Invitrogen, Madrid, Spain e \#15596-026) added in volumes of $250 \mathrm{~mL}$ (EC in inserts) or $500 \mathrm{~mL}$ Trizol (SC in the basal compartment) for 2 min. Upon collection, Media with lysed cells were 
centrifuged at $4 \stackrel{\circ}{\circ} 10 \mathrm{~min}$ and $12,000 \mathrm{~g}$. The supernatant (approximately 200 $\mathrm{mL}$, EC; over $500 \mathrm{~mL}, \mathrm{SC}$ ) was loaded in Eppendorf tubes, snap frozen in $\mathrm{LN}_{2}$ and stored at $-80^{\circ} \mathrm{C}$.

Total RNA was extracted from EC and SC using TRIsure (Bioline, Reus, Spain) and Direct-zol RNA miniprep kit (Zymo Research, E1009). Subsequently, RNA was eluted with Tris- $\mathrm{HCl}$. Immediately after extraction the $\mathrm{RT}$ reaction was carried out [32] using poly ( $\mathrm{T}$ ) primers, random primers, and MMLV High Performance Reverse Transcriptase enzyme (Epicentre Technologies Corp., Madison, U.S.A.) to prime the RT reaction and to produce cDNA. Tubes were heated to denature the secondary RNA structure and then the RT mix was completed with the addition of 50 units of reverse transcriptase. Tubes were then incubated at $25^{\circ} \mathrm{C}$ for $10 \mathrm{~min}$ to promote annealing of random primers, followed by $37^{\circ} \mathrm{C} 60$ min to allow the RT of RNA. Finally, the samples were incubated at $85^{\circ} \mathrm{C}$ for $5 \mathrm{~min}$ to denature the enzyme.

qPCR reactions were carried out in duplicate in the Rotorgene 6000 Real Time Cycler TM (Corbett Research, Sydney, Australia) by adding $5 \mathrm{ng}$ of each sample to the PCR mix (GoTaq qPCR Master Mix, Promega Corporation, Madison, USA) containing the specific primers selected to amplify the selected gene. qPCR reactions were run at $95^{\circ} \mathrm{C}$ for $3 \mathrm{~min}, 40$ cycles of $94^{\circ} \mathrm{C}$ for $15 \mathrm{~s}$, $56{ }^{\circ} \mathrm{C}$ for $30 \mathrm{~s}$ and $72{ }^{\circ} \mathrm{C}$ for $15 \mathrm{~s}$, and $10 \mathrm{~s}$ for fluorescence acquisition. Reactions were carried out in duplicate in the Rotorgene 6000 Real Time Cycler TM (Corbett Research, Sydney, Australia) by adding $5 \mathrm{ng}$ of each sample to the PCR mix (GoTaq qPCR Master Mix, Promega Corporation, Madison, USA) containing specific primers for HDGF (Hepatoma derived growth factor; Accesion NO: NM_175832.2; forward primer: GACCCACGAGACGGCATT; 
reverse primer: GCTGAACCCTTTCCTCTTGTTG; product length: 96 bp). Fluorescence was acquired in each cycle at temperature higher than melting temperature of primer dimers $\left(84^{\circ} \mathrm{C}\right)$. Then, the threshold cycle was determined for each sample. The comparative cycle threshold (CT) method was used to quantify expression levels and values were normalized to the endogenous, housekeeping control (H2AFZ; Histone; Accesion NO: NM_174809; forward primer: AGGACGACTAGCCATGGACGTGTG; reverse primer: CCACCACCAGCAATTGTAGCCTTG; product length: 208 bp). The $\triangle \mathrm{CT}$ value was determined by subtracting the mean housekeeping CT value for each sample from HDGF CT value of the sample. Fold changes in the relative gene expression of HDGF were determined using the formula 2- $\Delta \Delta \mathrm{CT}$ [33]. Primers were designed using Primer-BLAST software (www.ncbi.nlm.nih.gov/tools/primersblast/) to span exon-exon boundaries.

\subsubsection{Experimental design}

\subsubsection{Experiment 1: development of individually cultured morulae and early blastocysts in the presence of rHDGF}

On Day 6 of IVC, good-quality morulae and early blastocysts were selected and cultured individually for $24 \mathrm{~h}$ in $12 \mu \mathrm{L}$ drops of $\mathrm{mSOF}+$ with $\left(6 \mathrm{mg} \mathrm{mL}^{-1} \mathrm{BSA}\right)$ or without protein $\left(0.5 \mathrm{mg} \mathrm{mL}^{-1}\right.$ polyvinyl-alcohol, PVA, was added to replace BSA) under mineral oil. Cultures with PVA were a retrospective analysis of published development [14]; cultures with BSA were made on purpose. Culture media with BSA or PVA contained whether or not $r-H D G F$ in a concentration of $100 \mathrm{ng} \mathrm{mL}^{-1}$ [14]. Blastocyst development was monitored for 24 h (Day 7) and 48 h (Day 8). 


\subsubsection{Experiment 2: targeted HDGF protein quantification in UF and BSA supplements}

After flushing, recovered UF was aliquoted, stored at $-145^{\circ} \mathrm{C}$ and processed to quantify HDGF by MRM and WB. This experiment was repeated with $N=10$ animals, each providing 1 Sham Transfer and 1 embryo transfer sample. Subsequently, as HDGF had no effect on embryo development in BSA containing medium, the presence of HDGF was analyzed by WB in two commercial BSA preparations used in embryo culture.

\subsubsection{Experiment 3: influence of embryonic sex on gene expression of HDGF in cultured endometrial cells}

HDGF relative expression was quantified in EC and SC cultured for $48 \mathrm{~h}$ with one single male embryo, one single female embryo or no embryos (control).

\subsubsection{Experiment 4: pregnancy rates and birth measurements after transfer of embryos produced with rHDGF}

Day-7 expanded blastocysts derived from Day-6 morulae and early blastocysts cultured individually with or without $100 \mathrm{ng} \mathrm{mL}^{-1} \mathrm{r}$-HDGF in medium without protein (i.e. PVA), were transferred to recipients as fresh or vitrified warmed. Pregnancy was monitored by ultrasound on days 40 and 62, and miscarriage rates were controlled until birth. At birth, body weight, height at withers, thorax circumference, gestation length and average daily gain weight were measured in calves. 


\subsubsection{Statistical analysis}

Data requiring normalization were log transformed and analyzed using the Proc GLM module of SAS/STAT (version 9.2; SAS Institute Inc., Cary, NC). For embryo development rates, treatment (with or w/o HDGF), embryonic stage on Day-6 (morula and early blastocysts) were fixed effects; replicate was considered a random effect. For protein quantification in UF, fixed effects were cow, presence of embryos (i.e., ET vs. sham ET), analyzed gel (in the WB study), and replicate (i.e. round at which UF samples were collected). HDGF identification in BSA samples was qualitative. For pregnancy and birth rates, the effects considered were treatment (with or w/o HDGF), embryonic stage on Day-6 (morulae and early blastocysts) and ET round (replicate). For body measurements and birth weight, the fixed effects included were embryonic stage on Day-6, presence of HDGF in culture, bull, calf sex and recipient; season was a random effect. Least squares means and their errors $( \pm S E M)$ were estimated for each level of fixed effects with a significant F-value. The Ryane-Einote-Gabriele-Welsch Q-test was used as a post-hoc test to compare the raw means of the levels from the fixed effects $(P<0.05)$.

In the gene expression study, the effects considered were embryonic sex (male, female or no embryo), biological replicate (i.e. uterus sample) and technical replicate (repeated PCR analysis). Data were analyzed with software package SigmaStat 3.5 (Jandel Scientific, San Rafael, CA, USA). Fluorescence intensity of epithelial and stromal cells and relative mRNA abundances for candidate genes were compared. 


\subsection{Results}

\subsubsection{Embryo development}

In the presence of protein (i.e. BSA; Table 6.2), Day-6 morulae and early blastocysts were not affected by HDGF in their blastocyst development rates on days 7 and 8 . Early blastocysts showed higher blastocyst development rates than morulae. In the absence of protein (Table 3), development rates of Day-7 blastocysts grown from Day-6 early blastocysts with HDGF $(98.7 \pm 9.4)$ were twice those than without HDGF $(49.7 \pm 8.7)(P<0.01)$. Blastocyst rates with HDGF were numerically higher in all stages analyzed on Day-7 and Day-8 for Day-6 morulae and early blastocysts over their cognate non-treated embryos, although such differences were not significant.

\subsubsection{HDGF contents in uterine fluid}

For MRM, We analyzed $\mathrm{N}=10$ UF samples that contained embryos and $\mathrm{N}=10$ UF samples obtained after sham transfer. Proteotypic peptides programmed for HDGF were $N=5$. Out of them, the peptide LVIDEPTK was identified in all samples analyzed and showed the best signal to noise ratio, reproducibility and validation with a synthetic peptide. Relative abundance of HDGF between UFs containing or not containing embryos tended to differ $(2.85 \pm 0.6$ vs. $4.43 \pm 0.6$; respectively; $p=0.083$ ). 
Table 6.2. In vitro development of bovine morulae and early blastocysts cultured individually from day 6 to day 8 in droplets of synthetic oviduct fluid with BSA containing $100 \mathrm{ng} \mathrm{mL}^{-1}$ recombinant HDGF (rHDGF).

\begin{tabular}{|c|c|c|c|c|c|c|c|c|c|}
\hline \multicolumn{2}{|l|}{ Treatment } & \multirow[b]{2}{*}{$n$} & \multicolumn{3}{|c|}{ Day-7 Blastocysts (\%) } & \multicolumn{4}{|c|}{ Day-8 Blastocysts (\%) } \\
\hline Stage & [rHDGF] & & Total & Blastocysts & Expanded & Total & Blastocysts & Expanded & Hatched \\
\hline Morula & 0 & 184 & $79.5 \pm 3.3^{x}$ & $57.3 \pm 3.3^{x}$ & $23.4 \pm 8.7^{x}$ & $81.6 \pm 3.0^{x}$ & $66.6 \pm 2.8^{x}$ & $49.9 \pm 7.1^{\mathrm{a}}$ & $4.3 \pm 7.9$ \\
\hline Morula & 100 & 187 & $68.6 \pm 3.3^{x}$ & $54.4 \pm 3.3^{x}$ & $21.3 \pm 8.7^{x}$ & $76.0 \pm 3.0^{x}$ & $66.1 \pm 2.8^{x}$ & $45.6 \pm 7.1^{\text {ya }}$ & $5.7 \pm 7.9$ \\
\hline Early Blastocyst & 0 & 20 & $100.4 \pm 3.6^{y}$ & $100.7 \pm 3.5^{y}$ & $74.7 \pm 9.4^{y}$ & $101.2 \pm 3.3^{y}$ & $101.5 \pm 3.0^{y}$ & $88.0 \pm 7.7^{\mathrm{b}}$ & $22.8 \pm 8.6$ \\
\hline Early Blastocyst & 100 & 17 & $100.8 \pm 4.2^{y}$ & $101.7 \pm 4.1^{y}$ & $44.3 \pm 10.9$ & $100.9 \pm 3.8^{y}$ & $101.4 \pm 3.5^{y}$ & $76.1 \pm 8.9^{\mathrm{b}}$ & $12.6 \pm 10.0$ \\
\hline
\end{tabular}

Data were collected from 10 replicates and expressed as proportions (LSM \pm SEM) of Day- 6 cultured embryos $(n)$.

Values in the same column with different letters show significant differences: ${ }^{x, y}(p<0.01)$; $^{a, b}(p<0.05)$.

Table 6.3. In vitro development of bovine morulae and early blastocysts cultured individually from day 6 to day 8 in droplets of synthetic oviduct fluid with PVA containing $100 \mathrm{ng} \mathrm{mL}^{-1}$ recombinant HDGF (rHDGF).

\begin{tabular}{|c|c|c|c|c|c|c|c|c|c|}
\hline \multicolumn{2}{|l|}{ Treatment } & \multirow[b]{2}{*}{$n$} & \multicolumn{3}{|c|}{ Day-7 Blastocysts (\%) } & \multicolumn{4}{|c|}{ Day-8 Blastocysts (\%) } \\
\hline Stage & [rHDGF] & & Total & Blastocysts & Expanded & Total & Blastocysts & Expanded & Hatched \\
\hline Morula & 0 & 184 & $51.6 \pm 5.6^{x}$ & $30.1 \pm 8.1^{x}$ & $12.7 \pm 8.6^{a}$ & $62.2 \pm 7.4$ & $49.2 \pm 8.1^{\mathrm{a}}$ & $34.4 \pm 7.6^{x}$ & $3.7 \pm 6.0$ \\
\hline Morula & 100 & 183 & $63.1 \pm 5.6^{x}$ & $45.4 \pm 8.1^{x}$ & $17.1 \pm 8.6^{\mathrm{a}}$ & $75.5 \pm 7.4$ & $66.0 \pm 8.1$ & $48.5 \pm 7.6$ & $3.1 \pm 6.0$ \\
\hline Early Blastocyst & 0 & 20 & $90.3 \pm 6.1^{y}$ & $49.7 \pm 8.7^{x}$ & $46.7 \pm 9.3$ & $90.4 \pm 8.0$ & $83.3 \pm 8.7^{\mathrm{b}}$ & $57.6 \pm 8.3$ & $11.0 \pm 6.5$ \\
\hline Early Blastocyst & 100 & 20 & $100.0 \pm 6.5^{y}$ & $98.7 \pm 9.4^{y}$ & $56.6 \pm 10.0^{\mathrm{b}}$ & $89.3 \pm 8.7$ & $89.3 \pm 9.4^{\mathrm{b}}$ & $81.3 \pm 8.9^{y}$ & $12.5 \pm 7.0$ \\
\hline
\end{tabular}

Data were collected from 10 replicates and expressed as proportions ( $\mathrm{LSM} \pm \mathrm{SEM}$ ) of Day- 6 cultured embryos $(n)$.

Values in the same column with different letters show significant differences: ${ }^{x, y}(p<0.01){ }^{a, b}(p<0.05)$. 


\subsubsection{HDGF identification in BSA extracts}

HDGF protein was identified in commercial albumin preparations used in embryo culture, both embryo-culture tested BSA (Fig. 6.1, lanes 1 and 2) and FAF-BSA (Fig. 6.1, lanes 4 and 5). Western blot revealed an immunoreactive 28-kDa band with the molecular weight predicted for HDGF in albumin samples (BSA, lane 1; FAFBSA, lane 4). An extra band, 62-kDa, was detected in BSA samples, which probably corresponds to HDGF tightly bounded to BSA. The presence of HDGF was not observed within the analyzed PVA samples (Fig. 6.1 , lanes 3 and 6$)$.

\section{$\begin{array}{lllllllll}\text { L1 } & \text { L2 } & \text { L3 } & \text { L4 } & \text { L5 } & \text { L6 } & \text { L7 } & \text { L8 }\end{array}$}

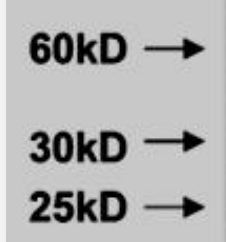

Fig. 6.1. Western blot analysis of HGDF in bovine cold-precipitated serum albumin (BSA) and bovine fatty-acid-free serum albumin (FAF-BSA). Albumin samples were diluted in water (BSA, Lane 1; FAF-BSA, Lane 4) and in Synthetic Oviduct Fluid (SOF) or (BSA, Lane 2; FAF-BSA, Lane 5); lanes 3 and 6 are BSA-free SOF with $0.5 \mathrm{mg} \mathrm{mL}^{-1}$ polyvinylalcohol. HGDF was also detected in positive control samples (bovine endometrium, Lane 7 and bovine uterine fluid Lane 8).

\subsubsection{Pregnancy and birth rates, and calf measurements, of embryos cultured with rHDGF}

Expanded blastocysts produced with or without rHDGF in culture from Day-6 to Day-7 were transferred after vitrification and warming. Results are shown in recipients that were transferred once or twice, and three or four times (Table 6.4). Pregnancy rates as main effects differed between recipients transferred 
once twice vs. three-four times within Day-60 pregnancy rate $(P<0.03)$ and birth rate $(P<0.01)$ (not shown). However, pregnancy and birth rates did not differ between embryos cultured with and without r-HDGF.

Table 6.4. Pregnancy and calving rates of recipients transferred 1-2 times and 3-4 times with bovine vitrified Day-7 expanded blastocysts individually cultured from Day-6 to Day7 in $12 \mu \mathrm{L}$ of synthetic oviduct fluid medium $+0.5 \mathrm{mg} \mathrm{mL}^{-1}$ PVA with or without rHDGF (100 $\left.\mathrm{ng} \mathrm{mL}^{-1}\right)$.

\begin{tabular}{lllll}
\hline HDGF & Transfers & \multicolumn{2}{l}{ Pregnancy rates (\%) } & \multirow{2}{*}{ Birth (\%) } \\
\cline { 3 - 4 } & & Day-40 & Day-60 & \\
\hline$(-)$ & $1-2$ & $20 / 32(62)$ & $20 / 32(62)$ & $12 / 24(50)$ \\
$(+)$ & $1-2$ & $6 / 16(37)$ & $6 / 16(37)$ & $6 / 16(37)$ \\
$(-)$ & $3-4$ & $0 / 3(0)$ & $0 / 3(0)$ & $0 / 3(0)$ \\
$(+)$ & $3-4$ & $2 / 4(50)$ & $1 / 4(25)$ & $0 / 4(0)$ \\
\hline
\end{tabular}

Pregnancy and birth rates expressed as \% ( $n$ pregnant $/ n$ transferred) at each specific endpoint; i.e. some pregnancies are in course).

At birth, calf weight, the other calf measurements, and daily gain weight did not differ between calves from embryos cultured with and without r-HDGF (Table 6.5). Average mother weight at birth did not influence birth weights of embryos cultured with $(529 \pm 60 \mathrm{Kg})$ or without $(515 \pm 42 \mathrm{Kg})$ r-HDGF (not shown).

Table 6.5. Weight and morphometry of calves born after transfer of bovine vitrified/warmed Day-7 expanded blastocysts cultured individually with or without $r$ HDGF (100 $\mathrm{ng} \mathrm{mL}^{-1}$ ) from Day-6 to Day-7.

\begin{tabular}{lclllll}
\hline HDGF & $\boldsymbol{n}$ & BW $(\mathbf{K g})$ & HW $(\mathbf{c m})$ & TC $(\mathbf{c m})$ & GL (days) & DG $\left(\mathbf{g ~ d a y ~}^{-1}\right.$ \\
\hline$(+)$ & 6 & $46.4 \pm 5.9$ & $80.8 \pm 5.9$ & $82.7 \pm 3.9$ & $282.2 \pm 3.7$ & $164 \pm 19$ \\
$(-)$ & 12 & $45.6 \pm 4.4$ & $78.3 \pm 4.2$ & $79.1 \pm 2.8$ & $285.9 \pm 2.7$ & $159 \pm 14$ \\
\hline
\end{tabular}

Body weight (BW), height at withers (HW), thorax circumference (TC), gestation length (GL), and average daily gain weight (DG) of the fetus. Differences were non-significant $(P>0.3)$. Data are LSM \pm SEM.

\subsubsection{Gene expression of HDGF in endometrial cell cultures}

In the gene expression study, $\mathrm{N}=4$ biological replicates from $\mathrm{N}=4$ animals were validated and used. Endometrial samples analyzed were $\mathrm{N}=6$ with male embryos, $\mathrm{N}=4$ with female embryos and $\mathrm{N}=4$ controls with no embryo. HDGF expression from EC cultured with a male embryo tended to be lower than 
control cells with no embryo $(P<0.08$; Fig. 6.2). In the presence of a female embryo, EC did not show such tendency.

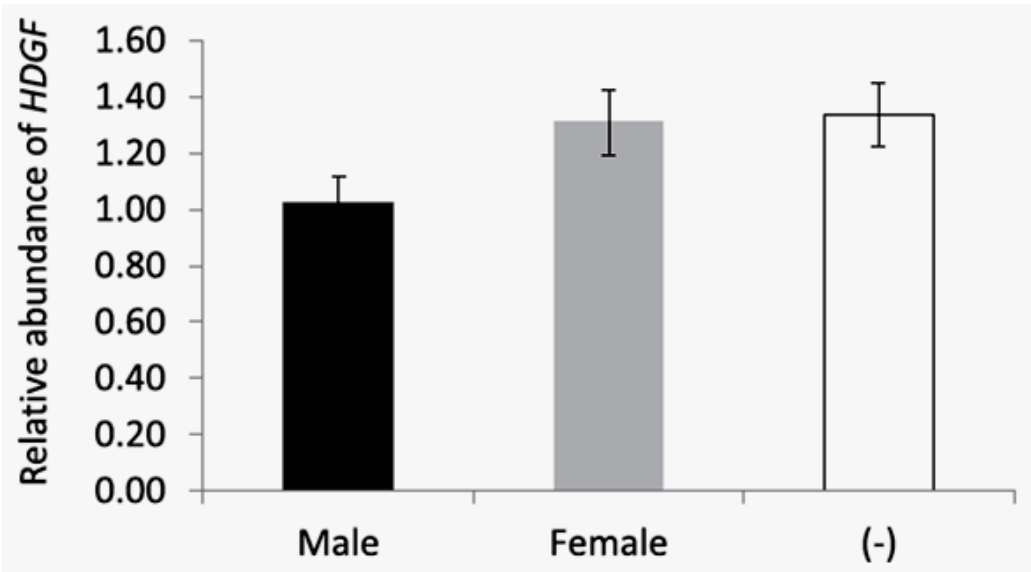

Fig. 6.2. Quantitative real-time PCR analysis of HDGF relative expression in epithelial cells cultured for $48 \mathrm{~h}$ with one single male embryo, one single female embryo or no embryos (control) $(P<0.05)$. ( $N=4$ biological replicates from $N=4$ animals, providing $n=6$ samples with male embryos, $\mathrm{N}=4$ with female embryos and $\mathrm{N}=4$ controls with no embryo).

\subsection{Discussion}

We identified here new aspects related to HDGF activity in bovine. In vitro embryo culture with r-HDGF showed lack of effect in the presence of protein, i.e. the conventional commercial BSA extracts. It is to understand this result that we used WB to analyze two common serum extracts in embryo culture experiments, i.e. BSA Fraction-V obtained by cold-precipitation, and FAF-BSA. We found that both BSAs contained appreciable levels of HDGF, which could be responsible for the lack of effect of exogenously added rHDGF to the culture. The presence of HDGF is not surprising in whole BSA, as this is a blood-borne extract. More interesting is the fact that the procedure for removing fatty acids is respectful with proteins that can be carried by BSA, such as HDGF, suggesting that studies testing GFs should first analyze their presence in the protein extracts used in order to discard confounding effects. 
In the absence of protein, however, the effects of rHDGF were obvious, consistent with our previous work [14]. In that study, performed without discrimination of embryonic stages on Day-6, we indicated that HDGF helps to advance the day 6 embryos throughout blastulation. In the present work we refined such finding, so far embryos that started blastulation were remarkably the target for the developmental stimulation exerted by rHDGF, likely together with some embryo termed as morula but that could have showed incipient blastulation (as observed by the numerically higher morula rates). Such effects can be explained as HDGF drives the epithelial to mesenchymal transition (EMT) in cancer and healthy cells, by downregulation of E-cadherin expression and upregulation of vimentin expression [34,35]. Interestingly, in the bovine blastocyst the trophectoderm formation is defined by markers cadherin and vimentin during the EMT [36]; therefore, the blastocyst can be a target for rHDGF.

In this work, the tendency of HDGF to decrease in UF, as analyzed by MRM, may contrast with previous work using 2D-DIGE, whereby HDGF in UF increased in the presence of multiple embryos [14]. However, our results can be in line with the lack of endometrial transcription to HDGF reported in response to the presence of embryos [14]. No correlation between HDGF mRNA and protein levels has also been described in a number of mouse tissues [39], leading to suggest that HDGF undergoes post-transcriptional and/or posttranslational regulation. We assume that total HDGF was measured, as the peptide identified with MRM is not susceptible of post-transcriptional modifications. In contrast, unlike in this MRM approach, 2D-DIGE typically excludes other spots with HDGF that can represent post-transcriptional 
modifications, as based in different $\mathrm{m} / \mathrm{w}$ ratio. Such differences could explain our findings, pointing out that post-transcriptional effects can be relevant in the uterus. Noteworthy, embryos drive the differential changes in proteins found in UF acting through the endometrium, apparently without non-physiological reactions [17]. At these early stages, protein of the embryonic masses present in the UF can be considered as negligible $(0.15 \mu \mathrm{g}$ protein/embryo [37]; $7.5 \mu \mathrm{g}$ protein/50 embryos transferred) in comparison with the total protein recovered from the uterus $(4500-5000 \mu \mathrm{g})$ [13] and the dilution effect of $3100 \mu \mathrm{g}$ protein renewal of endometrial origin in the UF per uterine horn in a day [38].

Whether cultured EC are able to react to male embryos by reducing the expression level of HDGF is intriguing. Sexual dimorphism in the early embryo development is mediated by molecular changes in UF in the live uterus [24]. Facultative maternal responses to early embryos could be required for purposes of gender balance or particular sensitivity to GFs among embryos of each sex [40]. Our results of HDGF expression in EC cultures would be not observed if embryos were not sexed (i.e. comparing embryo vs. no embryo). Thus, exposure of early embryos in vitro to the maternal cytokine Colony-Stimulating Factor 2 differentially affects growth and interferon tau release from male and female embryos in vivo [41].

Supplementation of embryo CM with $100 \mathrm{ng} \mathrm{mL}^{-1} \mathrm{rHDGF}$ was compatible with pregnancy and birth of calves with normal weight, gestation length and morphometry. Our study comprises limited numbers of embryo transfers, therefore it is still unknown if the increase in blastocyst production obtained with rHDGF [this work; 14] is accompanied by improved or conserved embryo viability. In terms of ICM and TE cell numbers, the quality of embryos produced 
with rHDGF surpasses that of the medium without rHDGF [14], yet it is unclear how such aspects can be related to our embryo transfer results. The effects of rHDGF on Day-7 blastocyst production, particularly acting on the Day-6 early blastocyst, are strictly stage dependent and better observed in individual than group culture [14]. Stage-specific expression of growth factors and receptors has been previously reported in mammalian pre-implantation embryos [42-45]. Therefore, developmentally-enhancing effects of HDGF can be associated with timing of activation of nucleolin, the HDGF receptor gene and protein, during the early bovine embryo development [11]. HDGF lacks a conserved secretory sequence signal present in classically secreted proteins, and its mechanism of extracellular secretion remains to be characterized. Thus, in ovarian cancer cells, HDGF is passively released by necrotic and late apoptotic cells [46]. In the uterus, where intense remodeling and cell detachment takes place, such a way of integrating HDGF in the UF could be feasible.

Perhaps rHDGF can be tested in culture with recombinant BSA as a carrier with properties different from the presumably inert PVA. In addition, as HDGF is a protein with specific glycosaminoglycan-binding residues [47] that serves to promote its internalization by cells [34], supplements as heparin/heparan sulphate or hyaluronan could modulate properties of rHDGF in culture. Adding HDGF to culture medium can improve the performance of cultures of individual embryos, allowing studies for modeling human embryo culture. In addition, cow donors that provide few viable oocytes by aspiration often require individual oocyte culture $[48,49]$. Otherwise, selective use of rHDGF could be reserved for specific embryonic stages (i.e. perhaps Day-6 early blastocysts, better than Day-6 morulae). Provided that the endometrium could react to the embryonic 
sex by changing HDGF gene expression levels, studies dealing with culture of sexed embryos with rHDGF should be accomplished. In this sense, we verified that the sex ratio of Day-7 expanded blastocysts that derive from Day- 6 early blastocysts in our culture system is significantly skewed to females [22]. More research is needed to identify precise culture conditions for rHDGF within bovine in vitro embryo culture.

In conclusion, the absence of products of animal origin in culture allows sanitary safe conditions. The use of maternal GFs in chemically defined conditions may approximate in vitro culture to the uterine environment without using products of animal origin. Species specific recombinant proteins, rarely used in bovine embryo culture, may help in this goal. Similar to other GFs identified in the uterus with a potential role during early development, HDGF acts selectively on specific embryonic stages. In addition, care should be taken with specific requirements derived from the nature of protein used (i.e., HDGF binding) within chemically defined conditions. Supplements used in culture can contain the GF in study, such as BSA with HDGF, thereby making it difficult to analyze in reliable conditions. Ultimately, the use of HDGF is compatible with pregnancy and birth of normal calves. 


\subsection{References}

[1] Kannampuzha-Francis J, Denicol AC, Loureiro B, Kaniyamattam K, Ortega MS, Hansen PJ. Exposure to colony stimulating factor 2 during preimplantation development increases postnatal growth in cattle. $\mathrm{Mol}$ Reprod Dev 2015; 82: 892-7. http://dx.doi.org/10.1002/mrd.22533.

[2] Denicol AC, Block J, Kelley DE, Pohler KG, Dobbs KB, Mortensen CJ, et al. The WNT signaling antagonist Dickkopf-1 directs lineage commitment and promotes survival of the preimplantation embryo. FASEB J 2014; 28:397586. http://dx.doi.org/10.1096/fj.14-253112.

[3] Sakagami N, Umeki H, Nishino O, Uchiyama H, Ichikawa K, Takeshita K, et al. Normal calves produced after transfer of embryos cultured in a chemically defined medium supplemented with epidermal growth factor and insulin-like growth factor I following ovum pick up and in vitro fertilization in Japanese black cows. J Reprod Dev 2012; 58:140-6.

[4] Block J, Hansen PJ, Loureiro B, Bonilla L. Improving post-transfer survival of bovine embryos produced in vitro: actions of insulin-like growth factor-1, colony stimulating factor-2 and hyaluronan. Theriogenology 2011; 76: 1602-9. http://dx.doi.org/10.1016/j.theriogenology.2011.07.025.

[5] Bonilla AQS, Ozawa M, Hansen PJ. Timing and dependence upon mitogen activated protein kinase signaling for pro-developmental actions of insulin like growth factor 1 on the preimplantation bovine embryo. Growth Horm IGF Res 2011; 21:107-11. http://dx.doi.org/10.1016/j.ghir.2011.03.003.

[6] Fields SD, Hansen PJ, Ealy AD. Fibroblast growth factor requirements for in vitro development of bovine embryos. Theriogenology 2011; 75:146675. http://dx.doi.org/10.1016/j.theriogenology.2010.12.007.

[7] Trigal B, Gómez E, Díez C, Caamaño JN, Martín D, Carrocera S, et al. In vitro development of bovine embryos cultured with activin $A$. http://dx.doi.org/10.1016/j.theriogenology.2010.09.010.

75:584-8.

[8] Lim KT, Jang G, Ko KH, Lee WW, Park HJ, Kim JJ, et al. Improved in vitro bovine embryo development and increased efficiency in producing viable calves using defined media. Theriogenology 2007;67:293-302. http://dx.doi.org/ 10.1016/j.theriogenology.2006.07.011.

[9] Gopichandran N, Leese HJ. The effect of paracrine/autocrine interactions on the in vitro culture of bovine preimplantation embryos. Reproduction 2006; 131:269-77. http://dx.doi.org/10.1530/rep.1.00677. 
[10] Nakamura H, Izumoto $Y$, Kambe H, Kuroda T, Mori T, Kawamura K, et al. Molecular cloning of complementary DNA for a novel human hepatomaderived growth factor. Its homology with high mobility group-1 protein. J Biol Chem 1994; 269:25143-9.

[11] Chen S-C, Hu T-H, Huang C-C, Kung M-L, Chu T-H, Yi L-N, et al. Hepatoma derived growth factor/nucleolin axis as a novel oncogenic pathway in liver carcinogenesis. Oncotarget 2015; 6:16253-70. http://dx.doi.org/10.18632/oncotarget.3608.

[12] Kishima Y, Yoshida K, Enomoto H, Yamamoto M, Kuroda T, Okuda Y, et al. Antisense oligonucleotides of hepatoma-derived growth factor (HDGF) suppress the proliferation of hepatoma cells. Hepatogastroenterology 2002; 49:1639-44.

[13] Muñoz M, Corrales FJ, Caamaño JN, Díez C, Trigal B, Mora MI, et al. Proteome of the early embryo-maternal dialogue in the cattle uterus. $J$ Proteome Res 2012; 11: 751-66. http://dx.doi.org/10.1021/pr200969a.

[14] Gómez E, Correia-Álvarez E, Caamaño JN, Díez C, Carrocera S, Peynot $\mathrm{N}$, et al. Hepatoma-derived growth factor: from the bovine uterus to the in vitro embryo culture. Reproduction 2014; 148: 353-65. http://dx.doi.org/10.1530/ REP-14-0304.

[15] Klein C. Novel equine conceptus? endometrial interactions on Day 16 of pregnancy based on RNA sequencing. Reprod Fertil Dev 2015; 28:1712. http://dx.doi.org/10.1071/RD14489.

[16] Martin FC, Ang C-S, Gardner DK, Renfree MB, Shaw G. Uterine flushing proteome of the tammar wallaby after reactivation from diapause. Reproduction 2016; 152: 491-505. http://dx.doi.org/10.1530/REP-16-0154.

[17] Gómez E, Muñoz M. Multiple-embryo transfer for studying very early maternal-embryo interactions in cattle. Reproduction 2015; 150: R35-43. http://dx.doi.org/10.1530/REP-14-0465.

[18] Gómez E, Martin D, Carrocera S, Sánchez-Calabuig MJ, Gutiérrez-Adán A, Alonso-Guervós $M$, et al. Expression and localization of ARTEMIN in the bovine uterus and embryos. Theriogenology 2017; 90: 153-62. http://dx.doi.org/10.1016/j.theriogenology.2016.12.007.

[19] Dobbs KB, Khan FA, Sakatani M, Moss JI, Ozawa M, Ealy AD, et al. Regulation of pluripotency of inner cell mass and growth and differentiation of trophectoderm of the bovine embryo by colony stimulating factor 2. Biol Reprod 2013; 89: 141. http://dx.doi.org/10.1095/biolreprod.113.113183.

[20] Loureiro B, Bonilla L, Block J, Fear JM, Bonilla AQS, Hansen PJ. Colonystimulating factor 2 (CSF-2) improves development and posttransfer 
survival of bovine embryos produced in vitro. Endocrinology 2009; 150: 5046-54. http://dx.doi.org/10.1210/en.2009-0481.

[21] Murillo-Ríos A, Maillo V, Muñoz M, Gutiérrez-Adán A, Carrocera S, MartínGonzález D, et al. Short- and long-term outcomes of the absence of protein during bovine blastocyst formation in vitro. Reprod Fertil Dev 2016. http://dx.doi.org/10.1071/RD15485.

[22] Gómez E, Carrocera S, Uzbekova S, Martín D, Murillo A, Alonso-Guervós $M$, Goyache F, Muñoz M. Protein in culture and endogenous lipid interact with embryonic stages in vitro to alter calf birthweight after embryo vitrification and warming. Reprod Fertil Dev. 2016. http://dx.doi.org/10.1071/ RD16213.

[23] Francis GL. Albumin and mammalian cell culture: implications for biotechnology applications. Cytotechnology 2010; 62:1-16. http://dx.doi.org/10.1007/s10616-010-9263-3.

[24] Gómez E, Caamaño JN, Corrales FJ, Díez C, Correia-Álvarez E, Martín D, et al. Embryonic sex induces differential expression of proteins in bovine uterine fluid. $J$ Proteome Res 2013; 12: 1199-210. http://dx.doi.org/10.1021/pr300845e.

[25] Lange V, Picotti P, Domon B, Aebersold R. Selected reaction monitoring for quantitative proteomics: a tutorial. Mol Syst Biol 2008; 4: 222. http://dx.doi.org/10.1038/msb.2008.61.

[26] Trigal B, Gómez E, Caamaño JN, Muñoz M, Moreno J, Carrocera S, et al. In vitro and in vivo quality of bovine embryos in vitro produced with sexsorted sperm. Theriogenology 2012; 78: 1465-75. http://dx.doi.org/10.1016/j.theriogenology.2012.06.018.

[27] Gómez E, Rodríguez A, Muñoz M, Caamaño JN, Carrocera S, Martín D, et al. Development and quality of bovine morulae cultured in serum-free medium with specific retinoid receptor agonists. Reprod Fertil Dev 2008; 20: 884-91.

[28] Hidalgo C, Díez C, Duque P, Prendes JM, Rodríguez A, Goyache F, et al. Oocytes recovered from cows treated with retinol become unviable as blastocysts produced in vitro. Reproduction 2005; 129: 411-21. http://dx.doi.org/10.1530/rep.1.00548.

[29] Caamaño JN, Gómez E, Trigal B, Muñoz M, Carrocera S, Martín D, et al. Survival of vitrified in vitro-produced bovine embryos after a one-step warming in straw cryoprotectant dilution procedure. Theriogenology 2015; 83: 881-90. http://dx.doi.org/10.1016/j.theriogenology.2014.11.021.

[30] Hidalgo CO, Gómez E, Prieto L, Duque P, Goyache F, Fernández L, et al. Pregnancy rates and metabolic profiles in cattle treated with propylene 
glycol prior to embryo transfer. Theriogenology 2004; 62: 664-76. http://dx.doi.org/10.1016/j.theriogenology.2003.11.006.

[31] Trigal B, Gómez E, Díez C, Caamaño JN, Muñoz M, Moreno JF, et al. Comparative study of PCR-sexing procedures using bovine embryos fertilized with sex-sorted spermatozoa. Span J Agric Res 2012; 10: 353-9. http://dx.doi.org/10.5424/sjar/2012102-447-11.

[32] Bermejo-Alvarez $P$, Rizos $D$, Lonergan $P$, Gutiérrez-Adán $A$. Transcriptional sexual dimorphism during preimplantation embryo development and its consequences for developmental competence and adult health and disease. Reproduction 2011; 141: 563-70. http://dx.doi.org/10.1530/REP-10-0482.

[33] Bermejo-Alvarez P, Rizos D, Rath D, Lonergan P, Gutiérrez-Adán A. Sex determines the expression level of one third of the actively expressed genes in bovine blastocysts. Proc Natl Acad Sci U. S. A. 2010; 107: 3394-9. http://dx.doi.org/10.1073/pnas.0913843107.

[34] Chen F-F, Lin W-H, Lin S-C, Kuo J-H, Chu H-Y, Huang W-C, et al. Significance of heparin binding to basic residues in homologous to the amino terminus of hepatoma-derived growth factor and related proteins. Glycobiology 2012; 22: 649-61. http://dx.doi.org/10.1093/glycob/cwr191.

[35] Tsai H-E, Wu J-C, Kung M-L, Liu L-F, Kuo L-H, Kuo H-M, et al. Upregulation of hepatoma-derived growth factor facilitates tumor progression in malignant melanoma [corrected]. PLoS One 2013; 8: e59345. http://dx.doi.org/10.1371/journal.pone.0059345.

[36] Yamakoshi S, Bai R, Chaen T, Ideta A, Aoyagi $Y$, Sakurai $T$, et al. Expression of mesenchymal-related genes by the bovine trophectoderm following conceptus attachment to the endometrial epithelium. Reproduction 2012; 143: 377-87. http://dx.doi.org/10.1530/REP-11-0364.

[37] Thompson JG, Sherman AN, Allen NW, McGowan LT, Tervit HR. Total protein content and protein synthesis within pre-elongation stage bovine embryos. Mol Reprod Dev 1998; 50: 139-45. http://dx.doi.org/10.1002/(SICI)1098-2795(199806)50.

[38] Hugentobler SA, Humpherson PG, Leese HJ, Sreenan JM, Morris DG. Energy substrates in bovine oviduct and uterine fluid and blood plasma during the oestrous cycle. Mol Reprod Dev 2008; 75: 496-503. http://dx.doi.org/10.1002/mrd.20760.

[39] Abouzied MM, Baader SL, Dietz F, Kappler J, Gieselmann V, Franken S. Expression patterns and different subcellular localization of the growth factors HDGF (hepatoma-derived growth factor) and HRP-3 (HDGF-related protein-3) suggest functions in addition to their mitogenic activity. Biochem J 2004; 378: 169-76. http://dx.doi.org/10.1042/BJ20030916. 
[40] Cameron EZ, Edwards AM, Parsley LM. Developmental sexual dimorphism and the evolution of mechanisms for adjustment of sex ratios in mammals. Ann N Y Acad Sci 2016. http://dx.doi.org/10.1111/nyas.13288.

[41] Dobbs KB, Gagn_e D, Fournier E, Dufort I, Robert C, Block J, et al. Sexual dimorphism in developmental programming of the bovine preimplantation embryo caused by colony-stimulating factor 2. Biol Reprod 2014; 91:80. http://dx.doi.org/10.1095/biolreprod.114.121087.

[42] Muñoz M, Rodríguez A, Díez C, Caamaño JN, Fernández-Sánchez MT, Pérez-Gómez A, et al. Tyrosine kinase A, C and fibroblast growth factor-2 receptors in bovine embryos cultured in vitro. Theriogenology 2009; 71 : 1005-10. http://dx.doi.org/10.1016/j.theriogenology.2008.11.008.

[43] Okumu LA, Forde N, Mamo S, McGettigan P, Mehta JP, Roche JF, et al. Temporal regulation of fibroblast growth factors and their receptors in the endometrium and conceptus during the pre-implantation period of pregnancy in cattle. Reproduction 2014; 147: 825-34. http://dx.doi.org/10.1530/REP-13-0373.

[44] Ozawa M, Yang Q-E, Ealy AD. The expression of fibroblast growth factor receptors during early bovine conceptus development and pharmacological analysis of their actions on trophoblast growth in vitro. Reproduction 2013; 145:191-201. http://dx.doi.org/10.1530/REP-12-0220.

[45] Sharkey AM, Dellow K, Blayney M, Macnamee M, Charnock-Jones S, Smith SK. Stage-specific expression of cytokine and receptor messenger ribonucleic acids in human preimplantation embryos. Biol Reprod 1995; 53: 974-81.

[46] Giri K, Pabelick CM, Mukherjee P, Prakash YS. Hepatoma derived growth factor (HDGF) dynamics in ovarian cancer cells. Apoptosis 2016; 21: 329-39. http://dx.doi.org/10.1007/s10495-015-1200-7.

[47] Chiu L-Y, Hung K-W, Tjong S-C, Chiang Y-W, Sue S-C. NMR characterization of the electrostatic interaction of the basic residues in HDGF and FGF2 during heparin binding. Biochim Biophys Acta 2014; 1844: 1851-9. http://dx.doi.org/10.1016/j.bbapap.2014.08.002.

[48] Hansen PJ. Medawar redux - an overview on the use of farm animal models to elucidate principles of reproductive immunology. Am J Reprod Immunol 2010; 64: 225-30. http://dx.doi.org/10.1111/j.1600-0897.2010.00900.x.

[49] Wydooghe E, Heras S, Dewulf J, Piepers S, Van den Abbeel E, De Sutter $P$, et al. Replacing serum in culture medium with albumin and insulin, transferrin and selenium is the key to successful bovine embryo development in individual culture. Reprod Fertil Dev 2014; 26:717-24. http://dx.doi.org/10.1071/RD13043. 


\section{7 | DISCUSIÓN GENERAL}

A. Murillo-Ríos

Centro de Biotecnología Animal, Servicio Regional de Investigación y Desarrollo Agroalimentario (SERIDA), Gijón, 33394 
La creciente demanda de proteína de origen animal y el desarrollo de una agricultura de precisión han incrementado notablemente el desarrollo de las tecnologías embrionarias. Las técnicas de producción de embriones in vitro han mejorado en gran medida desde su invención. Así, la optimización de sistemas y medios de cultivo ha permitido mejorar la viabilidad de los embriones PIV (Wrenzycki, 2016; Sirard, 2018).

En los dos primeros capítulos de la presente memoria de tesis, el sistema de cultivo in vitro implicó el cultivo de zigotos en grupo en medio SOFaaci suplementado con BSA desde día 1 hasta día 6. Más adelante, en el día 6, se seleccionaron mórulas $(\mathrm{M})$ y blastocistos tempranos $(\mathrm{EB})$ de buena calidad, los cuales se cultivaron individualmente en condiciones químicamente definidas reemplazando la BSA por PVA.

Observamos que el cultivo individual sin proteína desde el día 6 aumentó los porcentajes de blastocisto expandido $(\mathrm{XB})$ en día 7 obtenidos a partir de EB de día 6, frente a los obtenidos de $\mathrm{M}$ en día 6 . Además el cultivo individual durante $24 \mathrm{~h}$ en un medio libre de proteína produjo blastocistos expandidos de día 7 con mayores índices de nacimientos después de la vitrificación y la transferencia a receptoras. También se obtuvieron evidencias de que la cinética embrionaria y la vitrificación pueden impactar en los fenotipos al nacimiento, especialmente en hembras. De este modo, después de la vitrificación de embriones, la transferencia de EB-XB a receptoras produjo terneros con menores pesos al parto que cuando se transfirieron M-XB. Sin embargo, en el cultivo individual sin proteína solo el $10 \%$ de los embriones alcanzaron el estadio de EB en día 6. 
Tratando de aumentar los bajos índices de EB en día 6, en el capítulo tres evaluamos si una concentración mínima de suero era capaz de mejorar los porcentajes de EB en día 6. De esta manera, el cultivo individual sin proteína posterior al día 6 produciría más XB en día 7. El uso de una concentración muy baja $(0.1 \%)$ de suero en el cultivo hasta día 6 permitió triplicar la producción de EB y obtener así más XB de esta transición. En términos de calidad y viabilidad, los XB de día 7 cultivados con suero hasta el día 6 son comparables a los embriones producidos en SOF-BSA. Finalmente, en el cuarto capítulo se demostró que la concentración de HDGF total en el fluido uterino (FU), tendió a aumentar con la presencia de embriones en el útero. Además, se estableció que la expresión de HDGF fue menor en células endometriales cultivadas con un embrión macho frente a los cultivos de esas células sin embriones. Por último, se constató que la acción de HDGF recombinante (rHDGF), a partir del día 6 en cultivos individuales con o sin proteína, es dependiente del estadío embrionario y que la presencia de BSA puede enmascarar tales efectos.

\subsection{Restricción de proteína y desarrollo de embriones}

Solo el $10 \%$ de los embriones alcanzó el estadio de EB en el Día 6, y los porcentajes de desarrollo de M a XB fueron menores en ausencia de proteína. La ausencia de proteína redujo los porcentajes de blastocistos y la expansión en los días 7 y 8 a partir del estadío de M pero no a partir del estadío de EB en día 6. En bovino, durante el cultivo de embriones in vitro, los estadíos posteriores a la compactación requieren más proteína (Thompson, 1998) y aminoácidos (Guerif y cols., 2013) para su desarrollo que durante las primeras 
etapas de segmentación. El requerimiento de proteína parece ser estrictamente dependiente del estadío embrionario ya que, en contraste con la mórula, el EB de día 6 produce altos porcentajes de desarrollo y expansión en día 7 con y sin proteína.

Los estudios de cinética en embriones bovinos generalmente se han ocupado de analizar estadíos finales de desarrollo. Sin embargo, raramente se ha considerado el estadio de origen, a pesar de que para seleccionar embriones de viabilidad superior, la evaluación del desarrollo embrionario según patrones específicos se ha propuesto como más adecuada (Gutiérrez-Adán y cols., 2015).

Varios estudios han demostrado que la presencia de suero, a pesar de que puede inhibir las divisiones tempranas, estimula el desarrollo hasta el estadío de blastocisto (Rizos y cols., 2003; Loureiro y cols., 2009; Francis, 2010). Por tanto, con el fin de aumentar los porcentajes de EB se agregaron proporciones muy reducidas de suero desde el día 1 al día 6 , antes de la restricción de proteína. A partir de entonces, el estadío de EB, producido con y sin suero en cultivo hasta día 6 , dio lugar a mejores rendimientos de XB en día 7. Estos resultados sugieren que el EB requiere menos sustrato que el estadío de $M$ para alcanzar la etapa XB.

La adición de rHDGF en presencia de BSA no mostró efecto alguno sobre el desarrollo de blastocistos; sin embargo, en el cultivo libre de BSA, el rHDGF promovió principalmente el desarrollo de EB en contraste con M. Además, los efectos de rHDGF en la producción de blastocistos de día 7, se evidenciaron principalmente en EB de día 6. Tales efectos son estrictamente dependientes 
del estadío y se observan con más claridad en cultivo individual que en cultivo en grupo (Gómez y cols., 2014). El HDGF dirige la transición epiteliomesenquimal en células cancerígenas y en células sanas mediante la reducción de la expresión de E-cadherina y el aumento de la expresión de vimentina. Curiosamente, en el blastocisto bovino, la formación del TF también está definida por los marcadores de cadherina y vimentina durante la transición epitelio-mesenquimal (Yamakoshi y cols., 2012); por lo tanto, el blastocisto puede ser un blanco para el rHDGF.

Por otro lado, encontramos que tanto la BSA como la BSA libre de ácidos grasos analizadas en el último estudio contenían niveles apreciables de HDGF, lo que podría explicar la falta de efecto del rHDGF exógeno en cultivo. La presencia de HDGF en un extracto del suero como BSA Fracción-V, obtenido por precipitación sin modificación ulterior alguna, es en cierto modo esperable. Sin embargo, sorprende conocer que el procedimiento para eliminar los ácidos grasos de la BSA no ocasiona pérdida de bioactividad de algunas proteínas que la BSA puede transportar, como el HDGF. De esta manera, se debe analizar la presencia de un GF determinado en los extractos de proteína utilizados antes de estudiar sus efectos en cultivo, a fin de descartar posibles efectos indeseados.

Con los estudios que componen esta tesis hemos comprobado que usando cultivo individual sin proteína (condiciones químicamente definidas) es posible realizar análisis no invasivos del medio de cultivo (Gómez y cols., 2016) más precisos y garantizando la trazabilidad de la muestra. Además, el medio químicamente definido permite que otras moléculas de concentración conocida 
puedan ser añadidas (por ejemplo rHDGF) al medio de CIV para evaluar sus efectos.

\subsection{Morfología y recuento diferencial de células del blastocisto después de la restricción de proteína}

El estudio morfológico del blastocisto en día 7 después del cultivo individual con o sin proteína indica que la ausencia de proteínas no provoca diferencias morfológicas notables. Sin embargo, la ausencia de proteína en día 6 redujo el número de células en la $\mathrm{MCl}$ de los blastocistos de día 8 . La ausencia de proteínas durante todo el cultivo in vitro puede tener un impacto negativo sobre el desarrollo embrionario y afectar al número de células en embriones cultivados en grupos (Krisher y cols., 1999; Duque y cols., 2003; Orsi y Leese, 2004). Sin embargo, el menor número de células $\mathrm{MCl}$ en embriones cultivados sin proteína contrasta con la superior viabilidad a largo plazo que muestran estos embriones en el útero, a juzgar por el menor número de abortos que se producen.

Aunque un número mínimo de células embrionarias es necesario para establecer una gestación (Iwasaki y cols., 1990), el número óptimo de células y su distribución en el blastocisto no están claros.

En el capítulo tres, los embriones que provenían de cultivos in vitro en presencia de concentraciones reducidas de suero presentaron un color más oscuro en su citoplasma cuando se evaluaron con la luz del estereomicroscopio en día 6. Esta característica se mantuvo en parte en los XB de día 7 después 
del cultivo individual sin proteína. El número de células totales en blastocistos eclosionados que sobrevivieron a la vitrificación/calentamiento (v/c) no se vio afectado por la presencia de suero o el estadío embrionario en día 6.

\subsection{Restricción de proteína y supervivencia a la criopreservación}

La ausencia de proteína favoreció la supervivencia in vitro de los XB vitrificados en día 7. Todos los embriones v/c se reexpandieron tras $2 \mathrm{~h}$ de cultivo, lo que permite eliminar el cultivo previo a la transferencia, una operación costosa y que consume mucho tiempo. Curiosamente, después del cultivo individual sin proteína, ningún blastocisto fresco eclosionó en día 7. En el capítulo tres, el uso de FCS permitió seleccionar más blastocistos expandidos para ser vitrificados en día 7. La presencia de FCS hasta el día 6 no afectó los porcentajes de supervivencia in vitro después de la vitrificación de los XB en día 7. También observamos que los XB de día 7 que fueron producidos con FCS tendieron a eclosionar menos al cabo de $24 \mathrm{~h}$. Sin embargo, esto puede interpretarse como un retraso, ya que los porcentajes de eclosión se igualaron en todos los grupos al cabo $48 \mathrm{~h}$.

Sudano y cols., (2012) observaron que la incidencia de apoptosis en células embrionarias muestra una alta correlación con la supervivencia del embrión después de la criopreservación. También se ha demostrado que la suplementación con suero aumenta el número de células embrionarias (Gardner y cols., 2000; Van Langendonckt y cols., 1997), aunque otros estudios documentaron una reducción (Okumu y cols., 2014) del número de células. En 
nuestro estudio, observamos que ni la suplementación con FCS ni el estadío embrionario en día 6 (M o EB) aumentaron los porcentajes de apoptosis de blastocistos que eclosionaron después de la v/c. Además, el número total de células en los blastocitos eclosionados que sobrevivieron a la vitrificación no se vió afectado por la suplementación con FCS o el estadío embrionario en día 6.

\subsection{Contenido de lípidos intracelulares después de la restricción de proteína}

La reducción en el contenido de lípidos y su movilización, mejoran la supervivencia a la criopreservación y disminuyen el índice de apoptosis en embriones bovinos PIV (Ghanem y cols., 2014). La proteína exógena y el estadío embrionario en día 6 afectaron al contenido de lípidos observado en XB de día 7. La suplementación con proteína durante el CIV modificó el contenido de lípidos de XB en día 7 formados a partir de $M$ y EB en día 6. Las células embrionarias en estadío de $M$ contienen más gotas lipídicas que en EB (Sudano y cols., 2016). Sin embargo, las reservas de lípidos se redujeron en EB-XB, independientemente de la presencia o ausencia de proteína.

Con el inicio de la compactación de la M y durante la formación del blastocisto, las demandas de energía, analizadas como consumo de oxígeno y nutrientes, aumentan drásticamente. La capacidad de usar oxígeno en la M comparada con el EB podría estar aún limitada y, por tanto, entrañar una mayor dificultad para movilizar lípidos en ese estadío. En este sentido, Sudano y cols., (2016) describen que la acumulación de lípidos es mayor en estadíos de $\mathrm{M}$ frente a 
etapas posteriores. La lipogénesis está asociada con los gotas lipídicas más pequeñas, las cuales convergen para formar gotas más grandes mediante diferentes mecanismos (Thiam y cols., 2013). De esta manera, los embriones M-XB cultivados sin proteína mostraron menos gotas pequeñas y totales de lípidos que los embriones M-XB cultivados con proteína, sugiriendo que la eliminación de proteína condujo a una degradación de lípidos más pronunciada en embriones $\mathrm{M}-\mathrm{XB}$.

La fracción lipídica presente en el suero puede incorporarse a los embriones en desarrollo (Abe y cols., 2002) y afectar a la calidad de los blastocistos resultantes (Leroy, 2010). En nuestro estudio, la ausencia de FCS en el medio de cultivo redujo la acumulación intracelular de lípidos. La interacción entre el FCS y el estadío embrionario no afectó a la acumulación de lípidos en XB de día 7. Sin embargo, la presencia de $0,1 \%$ de FCS en cultivo aumentó la acumulación de lípidos en XB, aunque la supervivencia de los embriones a la $\mathrm{v} / \mathrm{c}$ y los porcentajes de apoptosis fueron similares a los embriones producidos en BSA.

\subsection{Expresión génica tras la restricción de proteína}

Los patrones de expresión génica que muestran los embriones frescos desaparecieron en los blastocistos que sobrevivieron a la vitrificación. En los blastocistos frescos, los cambios en la expresión génica a partir de la supresión de proteína se circunscribieron a la degradación de los lípidos y la apoptosis. En nuestro estudio, el incremento en la expresión de G6PD en embriones 
cultivados sin proteína puede ser reflejo de una capacidad superior de tales embriones para contrarrestar el estrés oxidativo inducido por la criopreservación. Es posible también que esta capacidad pueda asociarse a una mayor viabilidad embrionaria y a un menor porcentaje de abortos espontáneos, tal como hemos observado.

En embriones bovinos, la sobreexpresión de $B A X$ está vinculada a embriones de menor calidad (Vandaele y cols., 2008). Por tanto, la expresión reducida de $B A X$ en embriones cultivados sin proteína sugiere mayor calidad de estos embriones. La falta de diferencias en la expresión de GPX1 y SOD2, genes asociados a las mitocondrias y codificantes de enzimas antioxidantes, tanto antes como después de la criopreservación, indica ausencia de estrés oxidativo inducido por la supresión de proteína. Por el contrario, encontramos ATF4 y DDIT3 sobreexpresados en XB de día 7 que fueron privados de proteína antes de la criopreservación, lo cual indica que el estrés causado por la restricción de proteínas se limita al retículo endoplasmático. Curiosamente, estas diferencias, junto con la mayor expresión de IGF2R en embriones frescos, no se observaron en los blastocistos que sobrevivieron a la criopreservación. Por el contrario, la ausencia de proteína (Lim y cols., 2007) y diferentes sistemas de CIV (con suero o BSA) no alteraron la expresión de IGF2R con respecto al desarrollo in vivo en el oviducto ovino o en la vaca (Lazzari $y$ cols., 2002).

En nuestro estudio encontramos que la sobrerregulación de IGF2R en embriones cultivados sin proteína se asemeja más a las condiciones fisiológicas de los embriones en el tracto uterino. Por el contrario, una menor 
expresión de IGF2R se ha relacionado con el crecimiento excesivo del feto (Young, 2001) y el aborto en clones de ganado bovino (Yang y cols., 2013).

La expresión génica no se evaluó en nuestros experimentos de suplementación con FCS. Sin embargo, en un estudio realizado por Heras y cols., (2016) el transcriptoma de embriones producidos en condiciones libres de suero mostró una mayor semejanza con el transcriptoma de embriones in vivo, frente a los embriones cultivados en presencia de suero.

\subsection{Restricción de proteína y dimorfismo sexual}

El dimorfismo sexual durante el desarrollo embrionario temprano in vivo se evidencia en los cambios moleculares en el fluido del útero (Gómez y cols., 2014). Las mórulas y los blastocistos difieren en el número de genes expresados ligados al sexo y estas diferencias aumentan a medida que el embrión se desarrolla en la etapa de blastocisto (Denicol y cols., 2015). Sin embargo en nuestro estudio no encontramos cambios en la proporción esperada de embriones macho/hembra durante la transición de M-XB. Sin embargo, observamos porcentajes más elevados de embriones hembras dentro de las transiciones de EB-XB en comparación con M-XB. En bovino, cuando no se considera un patrón de desarrollo previo, aparece un mayor número de machos que de hembras entre los blastocistos que se desarrollan más rápido (Gutiérrez-Adán y cols., 1996, Larson y cols., 2001, Kimura y cols., 2005). Sin embargo, un cultivo individual de embriones por $24 \mathrm{~h}$ en SOFaaci con proteína no alteró la proporción total de sexos en los blastocistos (Muñoz y 
cols., 2014a, 2014b). Las discrepancias podrían explicarse por la reducción de las proporciones de EB entre los embriones de día $6(\approx 10 \%)$, ya que la proporción de sexos se ve influida solo en una baja proporción de los embriones analizados, de tal manera que el efecto puede ser inadvertido.

Curiosamente, los efectos sobre la proporción del sexo embrionario se asociaron claramente al estadío y no a la proteína, a pesar de que los embriones masculinos y femeninos difieren en el metabolismo de aminoácidos (Sturmey y cols., 2010) y en la regulación de proteínas que inducen en el fluido uterino (Gómez y cols., 2013). En nuestro sistema de cultivo verificamos que la mayor proporción de XB de día 7 que derivan de EB en día 6 está significativamente sesgada hacia el sexo hembra. No obstante, Heras y cols., (2016) describen que los embriones bovino PIV de sexo hembra parecen ser los menos afectados por las condiciones subóptimas de CIV (por ejemplo presencia de suero), siendo los embriones macho PIV los que muestran hasta tres veces más genes expresados diferencialmente comparados con embriones in vivo y con embriones in vitro hembra.

Los cultivos in vitro de células endometriales tendieron a reducir su nivel de expresión de HDGF ante la presencia de un embrión macho. La respuesta a la presencia del sexo del embrión temprano podría ser necesaria para adaptar el ambiente uterino a las distintas necesidades de los embriones macho o hembra, o bien podría obedecer a la particular regulación de determinados GFs entre embriones de cada sexo (Hansen y cols., 2016). Nuestros resultados de expresión de HDGF en cultivos de células endometriales no se observarían si 
no se hubiese considerado el sexo del embrión cocultivado (es decir, si comparamos solamente presencia o ausencia de embrión).

\subsection{Gestación y resultados perinatales}

En bovinos, un objetivo importante de la producción de embriones in vitro es mejorar los porcentajes de XB en día 7. En general, los XB de día 7 muestran índices de gestación más elevados que los embriones del día 8 y que estadíos embrionarios anteriores (Randi y cols., 2016; Kubisch y cols., 2004; Van Wagtendonk- de Leeuw y cols., 1998).

Los experimentos de supervivencia in vitro no han logrado predecir bien las diferencias en el porcentaje de nacimientos y abortos espontáneos ocasionados por embriones PIV. La restricción de proteína en el CIV redujo los porcentajes de aborto tardío, sugiriendo que el paso por un medio de cultivo sin proteína es beneficioso para lograr gestaciones a término. De hecho, en bovino, los blastocistos que se encuentran en el útero actúan reduciendo el volumen de fluido uterino secretado, medido como proteína total recuperable; y esta reducción se observa específicamente en la concentración de albúmina (Muñoz y cols., 2012). Como el paso por el útero es beneficioso para la viabilidad embrionaria y la supervivencia a la criopreservación (Rizos y cols., 2002; Lonergan y cols., 2004; Havlicek y cols., 2010), los efectos beneficiosos a largo plazo que observamos después de un corto periodo de supresión proteica durante el desarrollo tardío del blastocisto in vitro podrían ser equivalentes a los cambios fisiológicos que ocurren en el útero in vivo. Además, 
ese mismo efecto de reducción de proteína total inducido por un embrión macho también se ha observado en cultivos de células endometriales epiteliales (Gómez y cols., 2018b).

Los terneros nacidos después de la transferencia de EB-XB vitrificados en día 7 pesaron menos al nacimiento que los terneros derivados de M-XB de día 7. En bovinos, un peso elevado al nacimiento aumenta los riesgos de distocia, muerte fetal, mortalidad neonatal y daño a la madre (Van Wagtendonk-de Leeuw y cols., 1998; Bonilla y cols., 2014). Por lo tanto, la transferencia de EBXB vitrificados puede mejorar la facilidad de parto y el bienestar feto-materno. En los estudios con embriones vitrificados, la falta de proteína tendió a incrementar los porcentajes de nacimientos mediante la reducción del aborto espontáneo, lo que disminuye los perjuicios económicos, productos y de bienestar animal derivados de las pérdidas de gestaciones tardías. Curiosamente, la eliminación de proteínas durante la formación del blastocisto no afectó el peso al nacimiento, la duración de la gestación o la morfología de los terneros.

En bovino, el peso al nacimiento aumenta después de la transferencia de embriones cultivados in vitro en medio SOF con suero o con $16 \mathrm{~g} \mathrm{~L}^{-1}$ de BSA (Lazzari y cols., 2002), concentraciones ambas superiores a las utilizadas en los experimentos de esta tesis. En el estudio de Lazzari y cols., (2002) más del $50 \%$ de los terneros nacieron con $50 \mathrm{~kg}$ de peso, en contraste con nuestro estudio en donde obtuvimos una menor proporción de terneros con pesos elevados, aunque el número de casos no es aún elevado. 
Los embriones bovinos CIV con FCS (0.1\%) hasta el día 6 transferidos produjeron índices de gestación comparables a los producidos con embriones cultivados sin suero. Nuestros resultados preliminares sugieren que una baja concentración de FCS antes del cultivo individual sin proteína produce embriones viables a partir de varios estadíos embrionarios. Sin embargo, los efectos a largo plazo de la suplementación con suero asociada con el peso al nacimiento y el fenotipo de los terneros deben evaluarse en estudios futuros.

La suplementación de los medios de cultivo de embriones in vitro con 100 ng $\mathrm{mL}^{-1}$ de rHDGF fue compatible con gestaciones y el nacimiento de terneros con pesos, duración de la gestación y morfometría normales. Nuestro estudio comprende un número limitado de transferencias de embriones; por lo tanto, aún se desconoce si el aumento en la producción de blastocitos obtenidos con rHDGF conserva o mejora la viabilidad embrionaria. En cultivos en grupo de mórulas en medio libre de proteína y con PVA, rHDGF inhibió el desarrollo de blastocistos y no afectó al número de células cuando las mórulas eran tempranas (día 5), sin embargo, mejoró el desarrollo de blastocistos y aumentó el recuento celular cuando las mórulas eran compactas (día 6) (Gómez y cols., 2014).

El cultivo individual proporciona acceso rápido y directo a los medios de cultivo. De esta manera es posible realizar estudios de biomarcadores para determinar, de manera no invasiva, la viabilidad de la gestación (Muñoz y cols., 2014a, 2014b), el metabolismo de aminoácidos (Sturmey y cols., 2010) y diagnosticar el sexo del embrión (Muñoz y cols., 2014c; Gómez y cols., 2016; 2018b). Además, la restricción de proteína en cultivo individual es potencialmente 
compatible con cualquier otro sistema de cultivo hasta día 6 , proporcionando un medio homogéneo y repetible entre laboratorios. Los usuarios que deseen mejorar la supervivencia después de la criopreservación pueden asignar embriones a un medio de cultivo libre de proteína cuando no haya receptoras disponibles o cuando exista un excedente de embriones. 


\subsection{Referencias}

Abe H, Yamashita S, Satoh T \& Hoshi H. (2002). Accumulation of cytoplasmic lipid droplets in bovine embryos and cryotolerance of embryos developed in different culture systems using serum-free or serum-containing media. Mol Reprod Dev, 61(1), 57-66.

Bonilla L, Block J, Denicol AC, Hansen PJ. (2014). Consequences of transfer of an in vitro -produced embryo for the dam and resultant calf. J Dairy Sci. 97: 229- 239.

Denicol AC, Lea o BC, Dobbs KB, Mingoti GZ \& Hansen PJ. (2015). Influence of sex on basal and Dickkopf-1 regulated gene expression in the bovine morula. PLoS One 10, e0133587.

Duque, P., Hidalgo, C. O., Gómez, E., Pintado, B., Facal, N., and Díez, C. (2003). Macromolecular source as dependent on osmotic pressure and water source: effects on bovine in vitro embryo development and quality. Reprod. Nutr. Dev. 43, 487-496.

Francis G.L. (2010). Albumin and mammalian cell culture: implications for biotechnology applications. Cytotechnology 62, 1-16.

Ghanem N, Ha AN, Fakruzzaman M, Bang JI, Lee SC \& Kong IK. (2014). Differential expression of selected candidate genes in bovine embryos produced in vitro and cultured with chemicals modulating lipid metabolism. Theriogenology, 82(2), 238-250.

Gardner DK, Pool TB, Lane M. (2000). Embryo nutrition and energy metabolism and its relationship to embryo growth, differentiation and viability. Semin Reprod Med. 18:205-18.

Gómez E, Caamaño JN, Corrales FJ, Diez C, Correia-Álvarez E, et al. (2013). Embryonic sex induces differential expression of proteins in bovine uterine fluid. J Proteome Res 12:1199-210.

Gómez E, Correia-Álvarez E, Caamaño JN, Díez C, Carrocera S, et al. (2014). Hepatoma-derived growth factor: from the bovine uterus to the in vitro embryo culture. Reproduction. 148 (4): 353-365

Gómez E, Muñoz M, Simó C, lbáñez C, Carrocera S, et al. (2016). Noninvasive metabolomics for improved determination of embryonic sex markers in chemically defined culture medium. $J$ Chromatogr $A$; 1474:138-44.

Guerif F, McKeegan P, Leese HJ \& Sturmey RG. (2013). A simple approach for consumption and release (CORE) analysis of metabolic activity in single mammalian embryos. PloS one, 8(8), e67834. 
Gutiérrez-Adán A, Behboodi E, Andersen GB, Medrano JF \& Murray JD. (1996). Relationship between stage of development and sex of bovine IVM-IVF embryos cultured in vitro versus in the sheep oviduct. Theriogenology, 46(3), 515-525.

Gutiérrez-Adán A, Perez-Crespo M, Fernández-González R, Ramírez MA, Moreira P, et al. (2006). Developmental Consequences of Sexual Dimorphism During Pre-implantation Embryonic Development. Reproduction in Domestic Animals, 41(s2), 54-62.

Gutierrez-Adan A, White CR, Van Soom A \& Mann MR. (2015). Why we should not select the faster embryo: lessons from mice and cattle. Reprod Fert Dev, 27(5), 765-775.

Havlicek V, Kuzmany A, Cseh S, Brem G \& Besenfelder U. (2010). The Effect of Long-term In Vivo Culture in Bovine Oviduct and Uterus on the Development and Cryo-tolerance of In Vitro Produced Bovine Embryos. Reproduction in domestic animals, 45(5), 832-837.

Hansen PJ, Dobbs KB, Denicol AC \& Siqueira LG. (2016). Sex and the preimplantation embryo: implications of sexual dimorphism in the preimplantation period for maternal programming of embryonic development. Cell and tissue research, 363(1), 237-247.

Heras S, De Coninck DI, Van Poucke M, Goossens K, Pascottini O B, et al. (2016). Suboptimal culture conditions induce more deviations in gene expression in male than female bovine blastocysts. BMC genomics, $17(1), 72$.

Iwasaki S, Yoshiba N, Ushijima H, Watanabe S, Nakahara T. (1990). Morphology and proportion of inner cell mass of bovine blastocysts fertilized in vitro and in vivo. J Reprod Fertil, 90:279-284.

Kimura K, Spate LD, Green MP \& Roberts RM. (2005). Effects of D-glucose concentration, D-fructose and inhibitors of enzymes of the pentose phosphate pathway on the development and sex ratio of bovine blastocysts. Mol. Reprod. Dev. 72, 201-207.

Krisher RL \& Bavister BD. (1999). Enhanced glycolysis after maturation of bovine oocytes in vitro is associated with increased developmental competence. Mol. Reprod. Dev. 53:19-26

Kubisch HM, Sirisathien S, Bosch P, Hernandez-Fonseca HJ, Clements G, Liukkonen JR, et al. (2004). Effects of developmental stage: embryonic interferon-tau secretion and recipient synchrony on pregnancy rate after transfer of in vitro produced bovine blastocysts. Reprod Domest Anim. 39(2):120-4. 
Larson MA, Kimura K, Kubisch HM \& Roberts RM. (2001). Sexual dimorphism among bovine embryos in their ability to make the transition to expanded blastocyst and in the expression of the signaling molecule IFN-т. Proceedings of the National Academy of Sciences, 98(17), 9677-9682.

Lazzari G, Wrenzycki C, Herrmann D, Duchi R, Kruip T, Niemann H, et al. (2002). Cellular and molecular deviations in bovine in vitro produced embryos are related to the large offspring syndrome. Biol Reprod. 67:767-75.

Leroy, J. L. M. R., Genicot, G., Donnay, I., \& Van Soom, A. (2005). Evaluation of the lipid content in bovine oocytes and embryos with nile red: a practical approach. Reprod Domest Anim, 40(1), 76-78.

Lim KT, Jang G, Ko KH, Lee WW, Park HJ, et al. (2007). Improved in vitro bovine embryo development and increased efficiency in producing viable calves using defined media. Theriogenology 67, 293-302.

Lonergan P, Pedersen HG, Rizos D, Greve T, Thomsen PD, et al. (2004). Effect of the post-fertilization culture environment on the incidence of chromosome aberrations in bovine blastocysts. Biology of reproduction, 71(4), 1096-1100.

Loureiro B, Bonilla L, Block J, Fear JM, Bonilla AQ \& Hansen PJ. (2009). Colony-stimulating factor 2 (CSF-2) improves development and posttransfer survival of bovine embryos produced in vitro. Endocrinology. 150: 5046-5054.

Muñoz M, Corrales FJ, Caamaño JN, Díez C, Trigal B, Mora MI, Martín D, Carrocera S \& Gómez E. (2012). Proteome of the early embryo-maternal dialogue in the cattle uterus. Journal of Proteome Research. 11: 751-766.

Muñoz M, Uyar A, Correia E, Díez C, Fernández-González A, Caamaño JN, et al. (2014a). Prediction of pregnancy viability in bovine in vitro-produced embryos and recipient plasma with Fourier transform infrared spectroscopy. J Dairy Sci. 97(9):5497-507.

Muñoz M, Marquant-Le Guienne B, Fernandez-Gonzalez A, Díez C, Caamaño $\mathrm{JN}$, Trigal B, et al. (2014b). Metabolomic prediction of pregnancy viability in superovulated cattle embryos and recipients with fourier transform infrared spectroscopy. BioMed Res Int. 2014: 608579.

Muñoz M, Uyar A, Correia E, Díez C, Fernandez-Gonzalez A, Caamaño JN, et al. (2014c). Non-invasive assessment of embryonic sex in cattle by metabolic fingerprinting of in vitro culture medium. Metabolomics 10:443-51. 
Orsi, N. M., \& Leese, H. J. (2004). Amino-acid metabolism of preimplantation bovine embryos cultured with bovine serum albumin or polyvinyl alcohol. Theriogenology 61, 561-572.

Randi F, Fernandez-Fuertes B, McDonald M, Forde N, Kelly AK, et al. (2016). Asynchronous embryo transfer as a tool to understand embryo-uterine interaction in cattle: is a large conceptus a good thing? Reprod Fertil Dev. 28(12):1999-2006

Rizos D, Ward F, Duffy P, Boland MP \& Lonergan P, (2002b). Consequences of bovine oocyte maturation, fertilization or early embryo development in vitro versus in vivo: implications for blastocyst yield and blastocyst quality, Mol Reprod Dev, 61: (2), 234-48.

Rizos D, Gutierrez-Adan A, Perez-Garnelo S, De La Fuente J, Boland MP, Lonergan P. (2003). Bovine embryo culture in the presence or absence of serum: implication for blastocysts development, cryotolerance, and messenger RNA expression. Biol Reprod 68:236-43.

Sirard MA. (2018). 40 years of bovine IVF in the new genomic selection context. Reproduction. In press. doi: 10.1530/REP-18-0008.

Sturmey RG, Bermejo-Alvarez P, Gutierrez-Adan A, Rizos D, Leese HJ, and Lonergan P. (2010). Amino-acid metabolism of bovine blastocysts: a biomarker of sex and viability. Mol. Reprod. Dev. 77, 285-296.

Sudano MJ, Paschoal DM, Silva Rascado T, Crocomo LF, Magalhães LC, Martins Junior A, et al. (2012). Crucial surviving aspects for vitrified in vitro-produced bovine embryos. Zygote; 11:1-8.

Sudano MJ, Rascado TD, Tata A, Belaz KR, Santos VG, et at. (2016). Lipidome signatures in early bovine embryo development. Theriogenology, 86(2), 472-484.

Van Wagtendonk-de Leeuw AMJ, Mertonand AS, den Daas JHG. (1997). Pregnancy rates of IVP embryos. Proc.of the 13thScientific Meeting of the AETE, Lyon, France, p.212.

Van Wagtendonk-de Leeuw A, Aerts B, den Daas J. (1998). Abnormal offspring following in vitro production of bovine preimplantation embryos: a field study. Theriogenology 49:883-894.

Vandaele L, Goossens K, Peelman L \& Van Soom A (2008). mRNA expression of $\mathrm{Bcl}-2$, Bax, caspase-3 and-7 cannot be used as a marker for apoptosis in bovine blastocysts. Animal reproduction science, 106(12), 168-173. 
Thiam AR, Farese Jr, R.V \& Walther TC. (2013). The biophysics and cell biology of lipid droplets. Nature reviews Molecular cell biology, 14(12), 775.

Thompson JG, Sherman ANM, Allen NW, McGowan L T \& Tervit HR. (1998). Total protein content and protein synthesis within pre-elongation stage bovine embryos. Molecular Reproduction and Development: Incorporating Gamete Research, 50(2), 139-145.

Yamakoshi S, Bai R, Chaen T, Ideta A, Aoyagi Y, Sakurai T, et al. (2012). Expression of mesenchymal-related genes by the bovine trophectoderm following conceptus attachment to the endometrial epithelium. Reproduction, 143:377e87.

Wrenzycki C. (2016). In vitro culture systems: how far are we from optimal conditions?. Anim. Reprod, 13(3), 279-282.

Young LE, Fernandes K, McEvoy TG, Butterwith SC, Gutierrez CG, et al. (2001). Epigenetic change in IGF2R is associated with fetal overgrowth after sheep embryo culture. Nature genetics, 27(2), 153. 


\section{8 | CONCLUSIONES}

A. Murillo-Ríos

Centro de Biotecnología Animal, Servicio Regional de Investigación y Desarrollo Agroalimentario (SERIDA), Gijón, 33394 
Las conclusiones del presente trabajo de tesis son:

- La ausencia de proteína durante el Cl entre D6-D7 produce menos blastocistos expandidos, pero mejora su viabilidad a largo plazo después de la criopreservación.

- Una baja concentración de FCS es suficiente para mejorar los porcentajes de blastocisto temprano en día 6 , los cuales generan a su vez más blastocistos expandidos que las mórulas después de un día de cultivo individual sin proteína.

- La calidad de los blastocistos expandidos producidos con muy baja concentración de FCS es similar a los blastocistos producidos con BSA en términos de apoptosis, contenido de lípidos e índices de gestación.

- La cinética del embrión y la vitrificación condicionan los fenotipos al nacimiento. El peso de los terneros aumenta al transferir blastocistos vitrificados que provienen de mórula, un efecto que es más acentuado en las hembras. Las alteraciones están asociadas a la proteína exógena y la movilización de las reservas de lípidos.

- El uso de GFs de origen materno, producidos mediante síntesis recombinante, puede aproximar el cultivo in vitro en condiciones químicamente definidas al ambiente uterino.

- El HDGF actúa selectivamente en etapas embrionarias específicas durante el desarrollo temprano, al igual que otros GFs identificados en el útero bovino.

- El uso de rHDGF en cultivo de embriones in vitro es compatible con la gestación y el nacimiento de terneros normales. 